\title{
WestVirginiaUniversity
}

THE RESEARCH REPOSITORY @ WVU

Graduate Theses, Dissertations, and Problem Reports

2005

\section{Essays on value added tax evasion and tax amnesty programs}

Hari Sharan Luitel

West Virginia University

Follow this and additional works at: https://researchrepository.wvu.edu/etd

\section{Recommended Citation}

Luitel, Hari Sharan, "Essays on value added tax evasion and tax amnesty programs" (2005). Graduate Theses, Dissertations, and Problem Reports. 2246.

https://researchrepository.wvu.edu/etd/2246

This Dissertation is protected by copyright and/or related rights. It has been brought to you by the The Research Repository @ WVU with permission from the rights-holder(s). You are free to use this Dissertation in any way that is permitted by the copyright and related rights legislation that applies to your use. For other uses you must obtain permission from the rights-holder(s) directly, unless additional rights are indicated by a Creative Commons license in the record and/ or on the work itself. This Dissertation has been accepted for inclusion in WVU Graduate Theses, Dissertations, and Problem Reports collection by an authorized administrator of The Research Repository @ WVU.

For more information, please contact researchrepository@mail.wvu.edu. 


\title{
Essays on Value Added Tax Evasion and Tax Amnesty Programs
}

\section{Hari Sharan Luitel}

\author{
Dissertation Submitted to the \\ College of Business and Economics at \\ West Virginia University \\ in partial fulfillment of the requirements for the degree of \\ Doctor of Philosophy \\ in \\ Economics
}
Mehmet S. Tosun, Ph.D., Chair
Ronald J. Balvers, Ph.D.
Stratford M. Douglas, Ph.D.
Russell S. Sobel, Ph.D. William N. Trumbull, Ph.D.
Department of Economics
Morgantown, West Virginia
2005

Key words: VAT, tax evasion, OECD, tax amnesty, repeated amnesties, tax revenue 


\title{
ABSTRACT \\ Essays on Value Added Tax Evasion and Tax Amnesty Programs
}

\author{
Hari Sharan Luitel
}

Using a panel data from 1972 to 1999, the first essay of this dissertation analyzes how VAT evasion has changed as reliance on VAT in the sample of 25 OECD countries increased. The VAT ratio and VAT share are used as alternative measures of VAT reliance as independent variables. The results show that an increase in the VAT ratio and VAT share decreases VAT evasion. Overall, the results are quite robust to the various regression specifications.

Proponents argue that tax amnesties raise revenues both in the short run and the long run, by bringing former non-filers back into the tax system. Opponents contend that amnesties produce little short-run revenue and weaken incentives for long-run tax compliance. Over the last 23 years, 27 states offered tax amnesties for a second or third time. While previous research has estimated the impact of specific tax amnesties, none have estimated how the impact changes when they are offered repeatedly. The results from the second essay of this dissertation show that these additional tax amnesties generate less short-run revenue than predecessors and tend to magnify revenue losses associated with disincentives for long-run tax compliance.

The third and the last essay utilizes time series methods to analyze the Colorado, Maine and West Virginia tax amnesties, using quarterly total tax revenue data for the period from 1980 to 2002. The results show that the Colorado amnesty had no short run or long run impact on tax collections. At the same time, the results also show that the Maine and West Virginia tax amnesties raised revenues in the short run but that revenue collections actually fell in these states in the long run. 


\section{Dedicated to}

My father - Loknath Luitel

My mother - Radha Devi Luitel

My father-in-law - Late Narapati Chapagain

My mother-in-law - Ganga Devi Chapagain

My wife - Nirmala Luitel

My daughters - Pooja Luitel and Dipeeka Luitel 


\section{ACKNOWLEDGEMENT}

I would like to thank my advisor and dissertation chair, Mehmet S. Tosun, without his encouragement, this dissertation would have never become a reality. His encouragement always bolstered my spirit and kept me going. He is a role model of teacher, scholar, advisor and human being to me.

I also express my indebtedness to Russell S. Sobel. I am not only benefited from his expert professional guidance during my dissertation process but he also equipped me with the skills needed to be successful in the academic research. I highly appreciate the knowledge he has bestowed upon me.

I would like to thank William N. Trumbull, Ronald J. Balvers and Stratford M. Douglas, all members of my dissertation committee. Their helpful comments and suggestion helped me improve the quality of this dissertation.

In the process of doing Ph.D. at West Virginia University, I faced countless challenges and at the same time, I also received innumerable help from numerous people at various stages, I express my sincere gratitude to them all. I thank my bosom friend since my childhood, Ramchandra Bhandari for his good-natured ridiculing. He not only provoked me undertake Ph.D. but also supported me when I needed it the most. Also, I thank Swayam Prakash Sharma, my family friend, teacher and mentor and Anthony Bondurant, previous employer and a good American friend of mine, both of whom as a matter of fact paved the way for my study overseas. 
I reserve my special thanks for my family, especially for my parents, parents-inlaws, and brother-in-law, Ganesh Chapagain. Without their unconditional love and unfaltering support, I couldn't have achieved the success today.

Finally, my deepest gratitude goes to a very special person in my life, my love my wife, Nirmala Luitel. Despite all the troubles she undertook and countless sacrifices she made to help me remain focused and complete my study, she is always loving and caring to me. I thank her from the bottom of my heart. 


\section{Table of Contents}

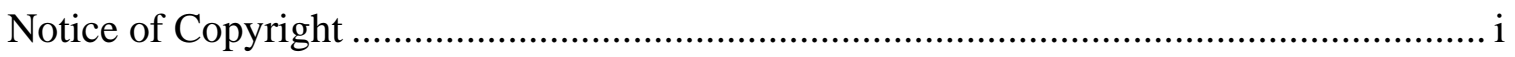

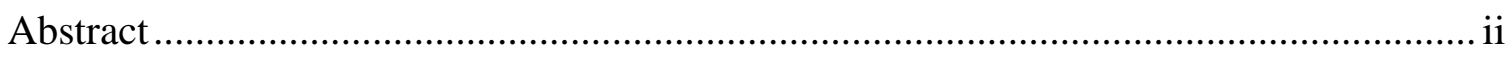

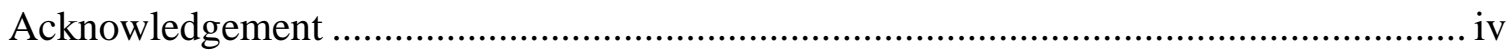

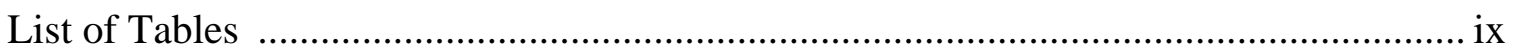

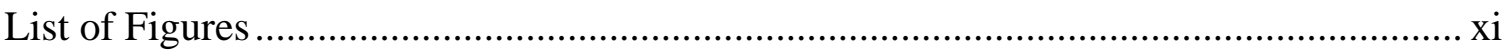

List of Abbreviations Used ..................................................................................... xii

Chapter 1:

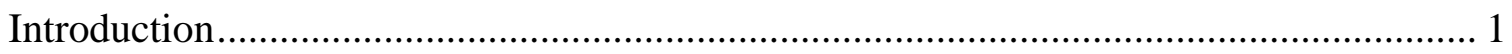

1.1 Dissertation Research Agenda ............................................................................ 1

Chapter 2:

Value Added Tax Evasion - an Empirical Analysis ........................................................... 4

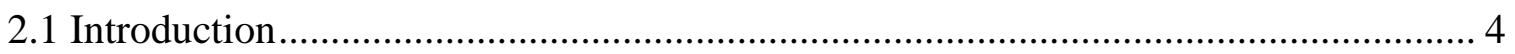

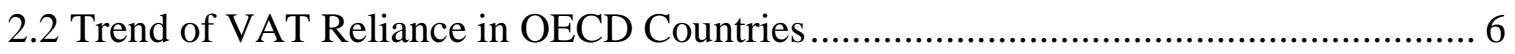

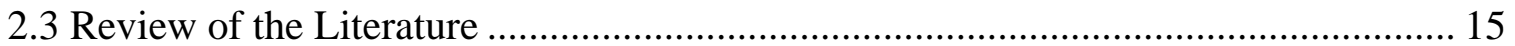

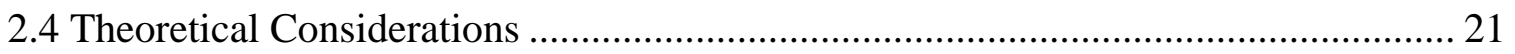

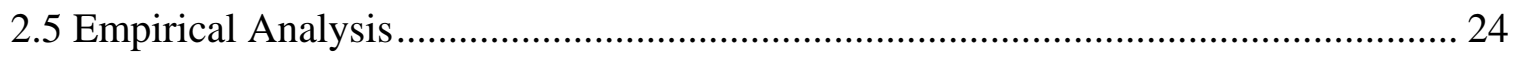

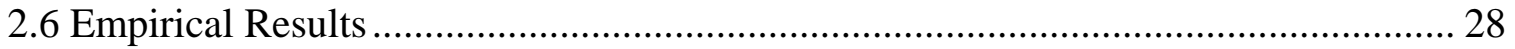

2.6.1 Robustness Check of the Results ............................................................. 31

2.6.2 Economic Significance ………………………….................................... 41

2.7 Summary and Conclusion....................................................................................... 41

Chapter 3:

The Revenue Impact of Repeated Tax Amnesties .............................................................. 43

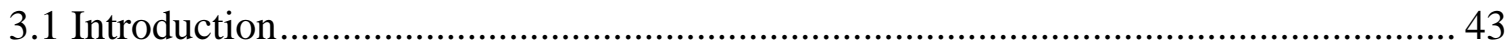

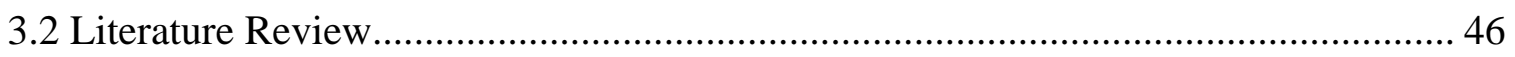


3.3 A Review of International Tax Amnesty Experience ................................................... 51

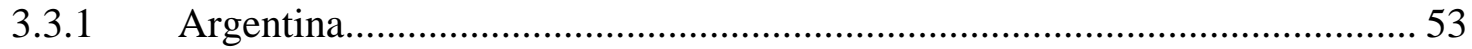

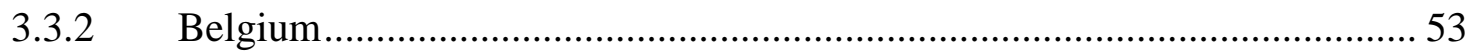

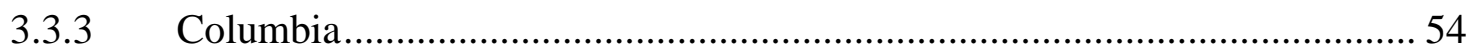

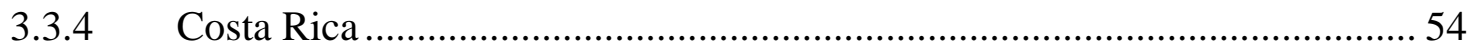

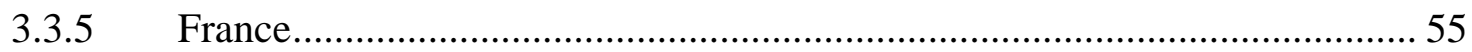

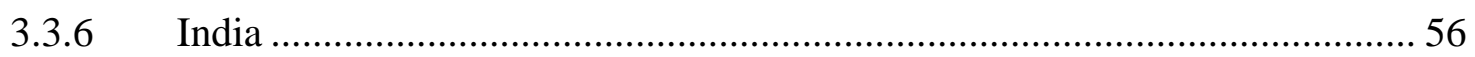

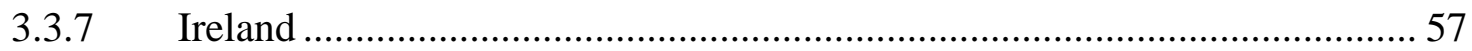

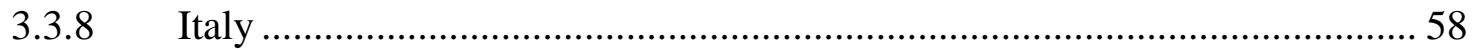

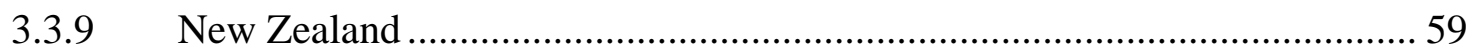

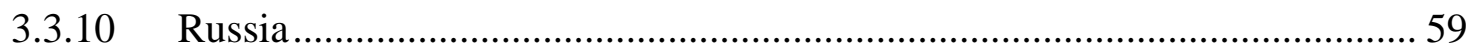

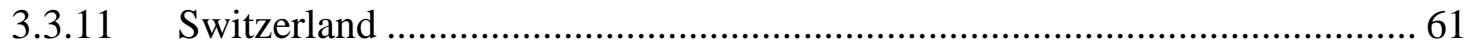

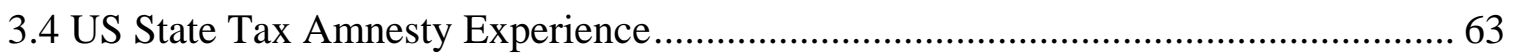

3.5 Empirical Analysis and Results ............................................................................. 72

3.6 Effect of Enforcement and Penalty on State Tax Amnesty ……………………….... 82

3.7 Effects of Allowing Known Delinquents on State Tax Amnesty ................................ 87

3.8 Effects of Permitting Installment Payment on State Tax Amnesty ............................. 90

3.9 Empirical Analysis and Results: Specific Tax Revenue............................................... 93

3.9.1 Results for Per Capita Sales Tax Revenue.................................................... 93

3.9.2 Results for Personal Income Tax Revenue ....................................................... 97

3.9.3 Results for Corporate Income Tax ............................................................... 101

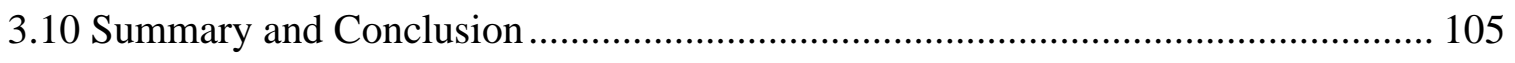

Chapter 4:

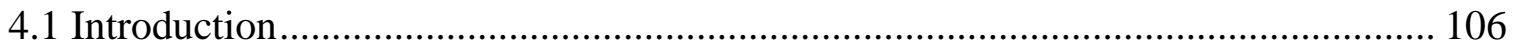

4.2 States Background Information and Tax Amnesty Programs.................................... 108

4.2.1 States Background Information ................................................................. 108

4.2.2 The 1985 Colorado Amnesty .................................................................... 110

4.2.3 The 1990 Maine Tax Amnesty …………………………........................ 111 
4.2.4 The 1986 West Virginia Tax Amnesty ................................................. 113

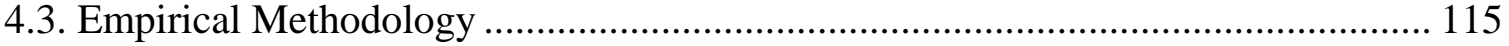

4.3.1 Semi-log Time Trend Analysis Results ............................................... 118

4.3.2 Time Series Intervention Analysis Results .......................................... 120

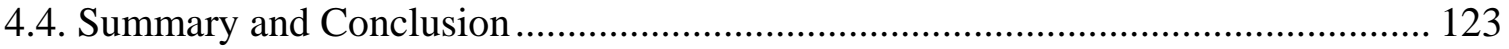

Chapter 5:

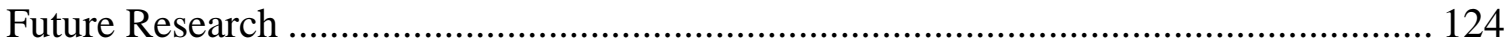

Appendix I - Tax Structure for Individual Sample OECD Countries ........................... 126

Appendix II - VAT GDP Ratio for Individual Sample OECD Countries ....................... 131

Appendix III - Data Description and Sources ............................................................ 136

Appendix IV - Matrix of Correlation Coefficients ..................................................... 137

Appendix V - Results of Breusch-Pagan / Cook-Weisberg test for Heteroskedasticity.. 138

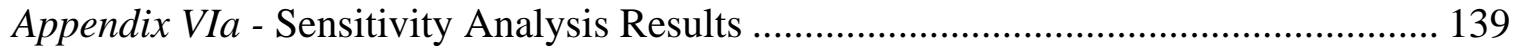

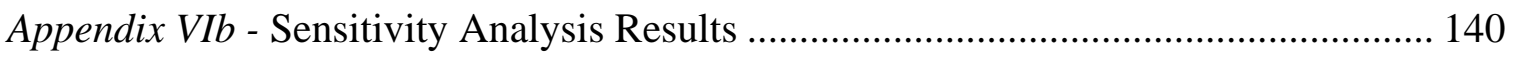

Appendix VIIa - Sensitivity Analysis Results ............................................................ 141

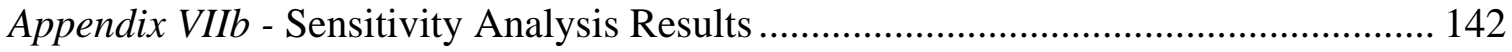

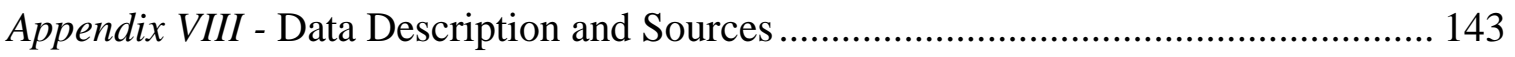

Appendix IX - Matrix of Correlation Coefficient ........................................................ 144

Appendix X - Results of Breusch-Pagan / Cook-Weisberg test for Heteroskedasticity.. 145 Appendix XIa - Regression Results for Per Capita Total Tax Revenue......................... 146

Appendix XIb - Regression Results for Per Capita Total Tax Revenue........................ 147

Appendix XIIa - Regression Results for Per Capita Sales Tax Revenue ........................ 148

Appendix XIIb - Regression Results for Per Capita Sales Tax Revenue ....................... 149

Appendix XIIIa - Regression Results for Per Capita Corporate Income Tax Revenue .. 150

Appendix XIIIb - Regression Results for Per Capita Corporate Income Tax Revenue .. 151

References: 


\section{List of Tables}

Table 2.1 - Introduction Date of VAT in OECD Member Countries ............................... 7

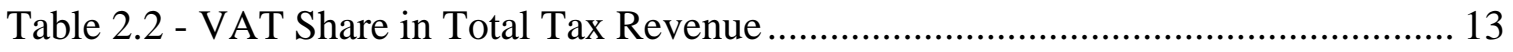

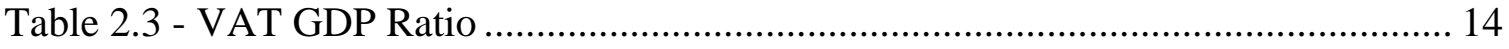

Table 2.4 - Summary of Literature Review ............................................................... 20

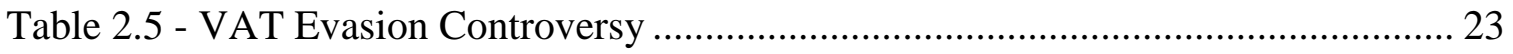

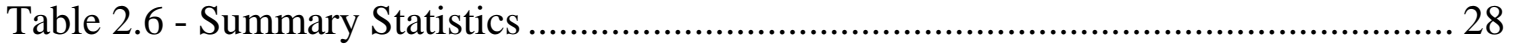

Table 2.7a - Regression Results for VAT Ratio as Independent variable ....................... 30

Table 2.7b - Regression Results for VAT Share as Independent variable....................... 31

Table 2.8a - Regression Results for VAT Ratio as Independent variable ....................... 33

Table 2.8b - Regression Results for VAT Share as Independent variable....................... 34

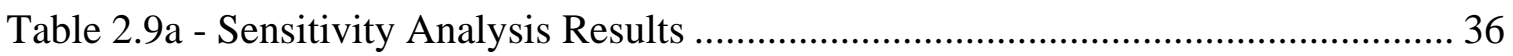

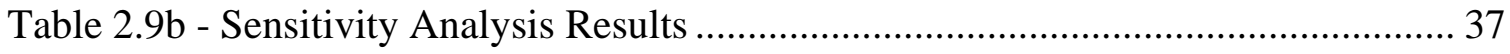

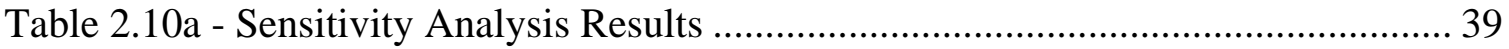

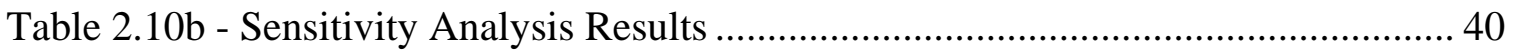

Table 3.1 - Arguments in Favor and Against Tax Amnesties........................................ 45

Table 3.2 - Summary of Literature Review …........................................................... 50

Table 3.3 - International Comparison of Tax Amnesties............................................... 52

Table 3.4 - Number of States Offering Tax Amnesties by Year .................................... 65

Table 3.5 - Characteristics of State Tax Amnesties $(1982$ - 2004) ................................. 66

Table 3.6 - State Tax Amnesty Periods and Ranking of Amnesty Collections (1982 -

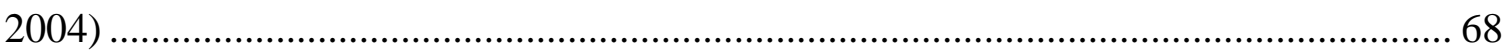

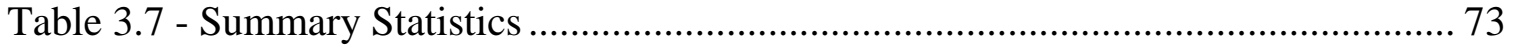

Table 3.8a - Regression Results for Per Capita Total Tax Revenue............................... 78

Table 3.8b - Regression Results for Per Capita Total Tax Revenue .............................. 79

Table 3.9 - Enforcement and Penalty Information of State Tax Amnesty Program (19821988) 
Table 3.10a - Regression Results for Increase in Enforcement and/or Penalty on Amnesty 85

Table 3.10b - Regression Results for Increase in Enforcement and/or Penalty on Amnesty 86

Table 3.11 - Delinquent Participation Information of State Tax Amnesty Program (19822004) 88

Table 3.12 - Regression Results for Delinquent Participation on Amnesty 89

Table 3.13 - Installment Arrangement Information of State Tax Amnesty Program (19822004)

Table 3.14 - Regression Results for Permitted Installment Arrangement of Tax Payment

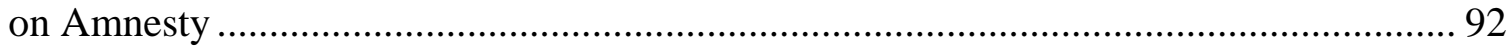

Table 3.15a - Regression Results for Per Capita Sales Tax Revenue.............................. 95

Table 3.15b - Regression Results for Per Capita Sales Tax Revenue ............................. 96

Table 3.16a - Regression Results with Panel Corrected Standard Errors for Per Capita

Personal Income Tax Revenue. 99

Table 3.16b - Regression Results with Panel Corrected Standard Errors for Per Capita

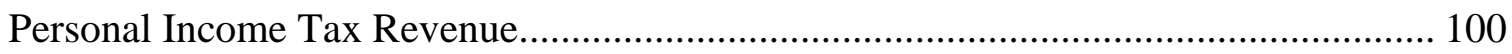

Table 3.17a - Regression Results for Per Capita Corporate Income Tax Revenue ........ 103

Table 3.17b - Regression Results for Per Capita Corporate Income Tax Revenue ........ 104

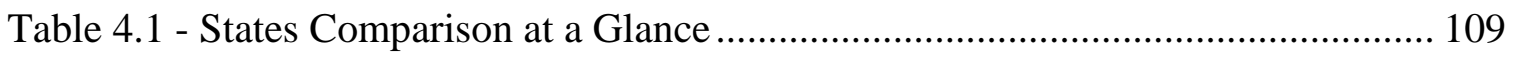

Table 4.2 - Taxes Included for the Amnesty.............................................................. 111

Table 4.3 - Comparative Characteristics of Amnesty …............................................. 112

Table 4.4 - Comparison of State Amnesty ................................................................. 115

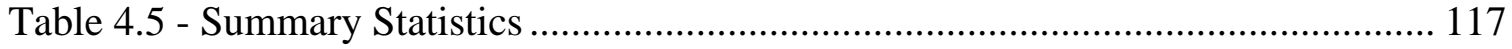

Table 4.6 - Total Tax Time Trend Results for Colorado ............................................. 119

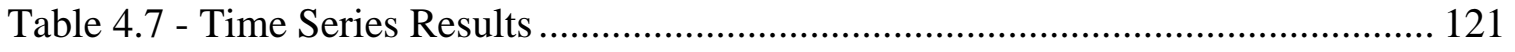




\section{List of Figures}

Figure 2.1 - Comparison of Standard VAT Rates ...................................................... 8

Figure 2.2 - VAT Revenue Per Capita and VAT Rate ................................................ 9

Figure 2.3 - Tax Structure: Average for the Sample of 25 OECD Countries .................. 10

Figure 2.4 - VAT GDP Ratio: Average for the Sample of 25 OECD Countries ............. 11

Figure 3.1 - Tax Amnesty Offerings by State (as of December 2004)............................ 64 


\section{List of Abbreviations Used}

$\begin{array}{ll}\text { ARIMA } & \text { Auto Regressive Integrated Moving Average } \\ \text { B\&O } & \text { Business and Occupation } \\ \text { EU } & \text { European Union } \\ \text { FTA } & \text { Federation of Tax Administrators } \\ \text { FY } & \text { Fiscal Year } \\ \text { GAO } & \text { General Accounting Office, United States } \\ \text { GDP } & \text { Gross Domestic Product } \\ \text { GSP } & \text { Gross State Product } \\ \text { IRS } & \text { Internal Revenue Services } \\ \text { JCT } & \text { Joint Committee on Taxation } \\ \text { MARIMA } & \text { Multivariate Auto Regressive Integrated Moving Average } \\ \text { NASBO } & \text { National Association of State Budget Officers } \\ \text { OECD } & \text { Organization of Economic Cooperation and Development } \\ \text { RST } & \text { Retail Sales Tax } \\ \text { UK } & \text { United Kingdom } \\ \text { US } & \text { United States of America } \\ \text { USD } & \text { United States Dollar } \\ \text { VAT } & \text { Value Added Tax } \\ & \end{array}$




\section{Chapter 1}

\section{Introduction}

Although taxation is regarded as the only practical means of raising revenues in a contemporary era to finance government spending on goods and services for its citizen, setting up an efficient and equitable tax system, especially in the presence of tax evasion and tax amnesties, is far from clear. It may appear that tax evasion and tax amnesty are different issues but they can be regarded as two sides of the same coin -- in the former, government deals with taxpayers with normal enforcement procedures of the tax system, whereas in the latter, it forgives taxpayers of their tax evasion allowing them a window opportunity to come back to the tax system without civil or criminal prosecution. This dissertation evaluates the anti-tax evasive characteristics of the value added tax (VAT) and the tax amnesty programs conducted by US states during the period from 1982 2002. Although the work is a positive analysis and incorporates inter- and intra- country comparisons, the results from this dissertation have some far reaching normative implications.

\subsection{Dissertation Research Agenda}

The VAT is the single most important development in the tax system during the last fifty years in terms of its contribution to government revenue, its rate, its base, and its geographical coverage and as such the VAT has become a standard element of the fiscal system in developed as well as developing countries throughout the world. A VAT is said to be neutral, successful in collecting revenue even from 'hard to tax sectors' and less 
susceptible to evasion. The VAT literature widely describes the anti-tax evasive characteristic of a VAT. However, there has been little systematic study of how VAT evasion has changed as countries increased their reliance on VAT over time. Chapter 2 of this dissertation empirically examines the relationship between the reliance on VAT and VAT evasion.

The practice of tax amnesty is not a new phenomenon; its history goes as far back as to ancient Rome. In the contemporary period, many developed as well as developing countries all over the world have increasingly conducted tax amnesties as part of their fiscal programs. Some countries have made repeated use of amnesties and sometimes the repetition of amnesty took place at an interval as short as every two years. Focusing on the United States, although no tax amnesty has been enacted at the federal level, the fifty states combined together offered a total of 76 tax amnesties during the past 23 years. Only 10 states have never offered a tax amnesty, 13 states have only offered a single amnesty and 27 states have offered a tax amnesty during this period on multiple occasions, 8 of them offering three or more amnesties. While previous research has estimated the impact of a specific tax amnesty for individual states, none have explored how the impact of a tax amnesty changes as it is offered more than once. Chapter 3 of this dissertation explores this issue.

While analyzing the data for chapter 3, I used fixed effects and random effects models, which are believed to extract the information from all the amnesties of all states combined together without regard to the success or failure of an individual state. Therefore, in chapter 4 which is an extension of my research in chapter 3, I analyze the 
short-run and long-run effects of the first amnesty in Colorado, Maine and West Virginia to determine if these amnesties were successful in bringing short-term and long-term revenues for the state treasury. 


\section{Chapter 2}

\section{Value Added Tax Evasion - an Empirical Analysis}

\subsection{Introduction}

The Value Added Tax (VAT) is one of the most important developments in the tax system during the last fifty years in terms of its contribution to government revenue, its rate, its base, and its geographical coverage and as such a VAT has become a standard element of the fiscal system in both developed as well as developing countries throughout the world. While only eight countries had had a VAT in the 1960s, now more than 120 countries have adopted VAT as a revenue-raising device (Cnossen 1998, Ebril, Keen, Bodin and Summers 2001). The increasing popularity of a VAT can be attributed to its characteristics. A VAT is said to be not only neutral and successful in collecting revenue even from 'hard to tax sectors' in the economy but also less susceptible to evasion (Cnossen 1987, U.S. Treasury Department 1984).

A VAT is comparable to a retail sales tax (RST) in that the retail price or value of a product or service can be thought of as being equal to the total of the value added in the production and distribution process. A VAT that extends through the retail level, therefore, would collect essentially the same amount of tax on a product as would a RST levied at the same rate of tax. A VAT, however, differs from a RST in that the tax is collected piecemeal, in several stages, rather than exclusively on the retail level (U.S. Treasury Department 1984). Under the invoice method of VAT, each firm pays tax on its sales and receives a credit for taxes invoiced by its supplier. Tax evasion is possible if the seller is successful in understating the amount on the invoice or the buyer is successful in 
overstating the amount on the invoice. However, if a VAT is in place, it will be in the seller's interest not to allow the buyer to cheat by overstating the amount on the invoice. On the other hand, it will be in the buyer's interest not to allow the seller to cheat by understating the amount on the invoice. These two opposing forces deter both buyers and sellers from misreporting, which makes the VAT more difficult to evade (Shoup 1986, Cnossen 1987, Slemrod 1990).

Although this anti-tax evasive characteristic of a VAT has been widely discussed in the literature, there has been little systematic study of how VAT evasion has changed over time. Put differently, while a VAT is, theoretically, anti-tax evasive, in this chapter, I test if this is also supported statistically. For this I empirically analyze the relationship between the reliance on VAT and VAT evasion using panel data from 1972 to 1999 for a sample of 25 OECD countries in order to bring new evidence on how VAT evasion changes as countries increase their reliance on VAT. I run regressions separately on two alternative measures of VAT reliance as independent variables. These measures are the VAT ratio, defined as the ratio of VAT to GDP, and the VAT share, defined as the share of VAT in total tax revenue. My results show a negative relationship between these measures of VAT reliance and VAT evasion. In other words, an increase in the VAT ratio and VAT share decreases VAT evasion. These results are quite robust to various regression specifications. 


\subsection{Trend of VAT Reliance in OECD Countries}

The role of VAT in the tax system has dramatically changed in OECD countries in the past three decades. ${ }^{1}$ Although Denmark adopted modern VAT in 1967, France was the pioneering country in experimenting VAT in its variant forms since $1948 .^{2}$ The VAT was introduced in Austria, Belgium, France, Germany, Greece, Ireland, Italy, Luxembourg, the Netherlands, Portugal and Spain with an aim to harmonize the tax as these countries became part of the common market. In the Scandinavian countries and several other OECD countries, on the other hand, VAT was introduced with an aim of increasing consumption tax yields, because in comparison to sales taxes it is easier to integrate taxes on services, to exempt investment goods and to having some inherent anti-evasion features built into it (Messer, 1983). Table 2.1 presents the VAT introduction date in the OECD countries -- twenty-nine of thirty OECD member countries have a VAT. Most of the OECD countries are also members of the European Union (EU) and one reason why the VAT is so wide-spread in Europe is that having a VAT is a condition to become a member of the EU (Messere 1997). Currently, the only OECD member country which does not have a VAT is the United States. ${ }^{3}$

\footnotetext{
${ }^{1}$ For general discussion of OECD tax trend, see Messere (1983, 1993, 1997 and 1999) and OECD (2001). For an empirical analysis of tax structure change in OECD countries during 1980-1999, see Tosun and Abizadeh (forthcoming).

${ }^{2}$ OECD (1988), pp. 79.

${ }^{3}$ There are two reasons why a VAT is opposed in the United States. Firstly, the right to impose general consumption taxes has always been reserved to sub-central government. Secondly, it is feared that a federal VAT would lead to an overall increase in tax levels. Justification for the second fear lies on the fact that virtually all governments have increased VAT rates. Also, all first generation countries except France increased VAT revenues as a percentage of GDP (Messere 1999).
} 
Table 2.1 - Introduction Date of VAT in OECD Member Countries

\begin{tabular}{|l|l|l|c|}
\hline \multicolumn{1}{|c|}{ Countries } & $\begin{array}{c}\text { VAT introduced } \\
\text { Date }\end{array}$ & Countries & $\begin{array}{c}\text { VAT introduced } \\
\text { Date }\end{array}$ \\
\hline Australia & 2000 & Korea Republic & 1977 \\
\hline Austria & 1973 & Luxembourg & 1970 \\
\hline Belgium & 1971 & Mexico & 1980 \\
\hline Canada & 1991 & Netherlands & 1969 \\
\hline Czech Republic & 1993 & New Zealand & 1986 \\
\hline Denmark & 1967 & Norway & 1970 \\
\hline Finland & 1994 & Poland & 1993 \\
\hline France & 1968 & Portugal & 1986 \\
\hline Germany & 1968 & Slovak Republic & 1993 \\
\hline Greece & 1987 & Spain & 1969 \\
\hline Hungary & 1988 & Sweden & 1995 \\
\hline Iceland & 1990 & Switzerland & 1985 \\
\hline Ireland & 1972 & Turkey & 1973 \\
\hline Italy & 1973 & United Kingdom & N/A \\
\hline Japan & 1989 & United States & \\
\hline Sal & and & \\
\hline
\end{tabular}

Source: Cnossen (1998), Ebril, Keen, Bodin and Summers (2001).

The tax rate and tax base are two sources of a change in the reliance of a tax, so is the case with the VAT. Figure 2.1 compares the standard VAT rate in countries the VAT was introduced vs the rate in 1999. The standard VAT rate has increased in 18 of the 25 sample OECD member countries. Figure 2.2 shows an overall increase in the average standard VAT rate for the sample of 25 OECD countries, which has increased from 15.6 percent in 1972 to 17.9 percent in 1999. In six countries, the rate has not changed and in one country, the Czech Republic, it has decreased. Note that all the first generation 
countries have experienced an increase in the standard VAT rate and that the six countries, Canada, Finland, Greece, Hungary, Korea and Poland where the rate has not

Figure 2.1 - Comparison of Standard VAT Rates (Initial Rate at the Start of VAT vs Rate in 1999)

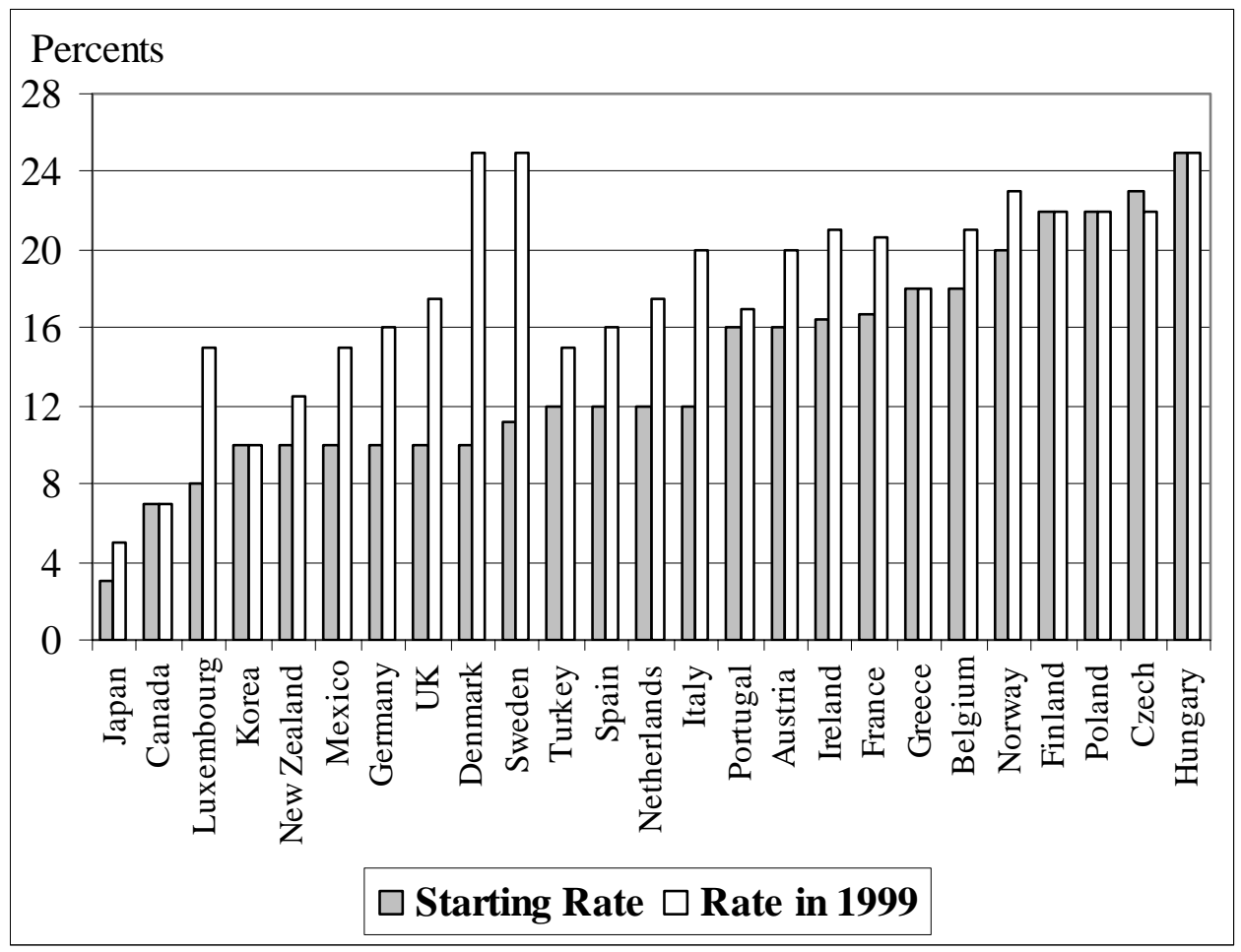

changed, are relatively new convert to the VAT except Korea, which introduced a VAT in $1977 .{ }^{4}$ Figure 2.2 also shows the average VAT revenue per capita in real terms for the sample of 25 OECD countries, which rose sharply until 1979 and then declined until 1985, after which again it can be observed gradually rising over the years. A rise in the VAT per capita would lead to an increase in the VAT share as well as VAT ratio. Let us

\footnotetext{
${ }^{4}$ First generation refers to the countries which adopted a VAT between 1967 and 1973.
} 
now turn to look at what happened to these measures after the introduction of VAT in the OECD countries.

Figure 2.2 - VAT Revenue Per Capita and VAT Rate (Averages for 25 OECD Countries)

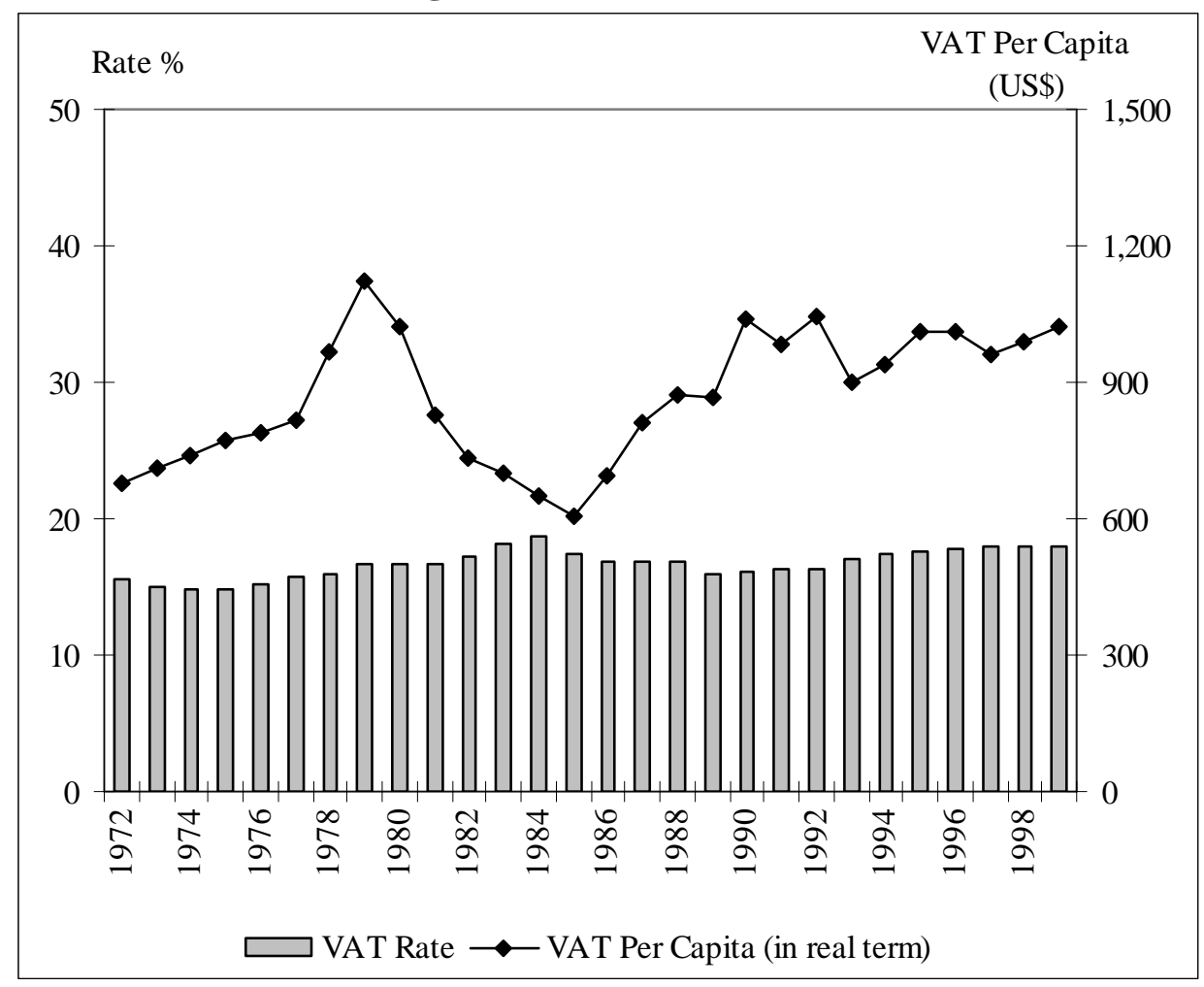

Figure 2.3 shows that overall the VAT share ranks the third in the sample of 25 OECD countries. Social security tax and personal income taxes are the other two major sources of tax revenue in the sample countries whose weights are higher than that of a VAT. The VAT share for the sample of 25 OECD countries at five years interval is presented in Table 2.2. A closer look at the tax structure of individual countries shows 
that the VAT share ranks third or higher in 22 of the 25 sample OECD countries. ${ }^{5}$ Interestingly, the weight of VAT is higher than the personal income tax in countries such as France, Greece and Portugal but in countries such as Denmark, Mexico and United Kingdom the weight of VAT is higher than the social security tax. Canada, Luxembourg

Figure 2.3 - Tax Structure: Average for the Sample of 25 OECD Countries

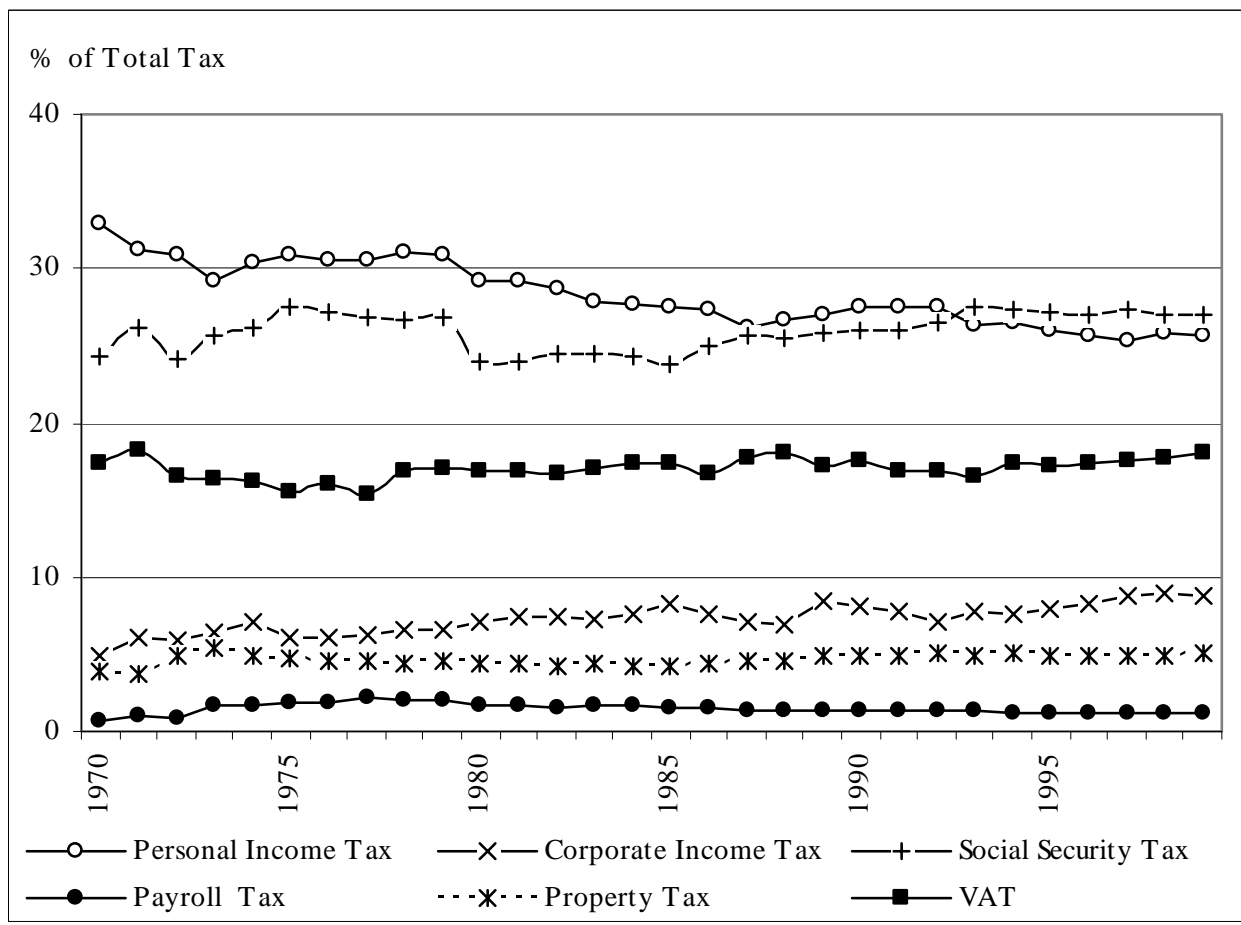

and Japan are the three countries where the VAT share is lower than third in rank. It ranks fourth for Luxembourg, sixth for Canada and it is the lowest of all types of taxes in Japan. However, note that the VAT share is stable between 6 and 7 percent in Canada and

\footnotetext{
${ }^{5}$ Graphs for individual countries' tax structure are provided in Appendix I. I look at major tax categories only. These categories are personal income tax, corporate income tax, social security tax, payroll tax, property tax and VAT. If any tax is not listed above, they are included in other category, which I exclude from the analysis here.
} 
it is increasing in both of the other two countries, Japan and Luxembourg. While the VAT share increased in Luxembourg from 11 percent in 1971 to 14 percent in 1999, it increased in Japan from 3 percent in 1989 to 9 percent in 1999. The increase in VAT share is also remarkable in Hungary and Poland. In Hungary, while the VAT share ranked only third in 1991, it ranked second in 1999. Likewise, in Poland, it ranked the fourth in 1993, but its share increased as high as personal income tax, the second in the rank, in 1999.

Figure 2.4 - VAT GDP Ratio: Average for the Sample of 25 OECD Countries

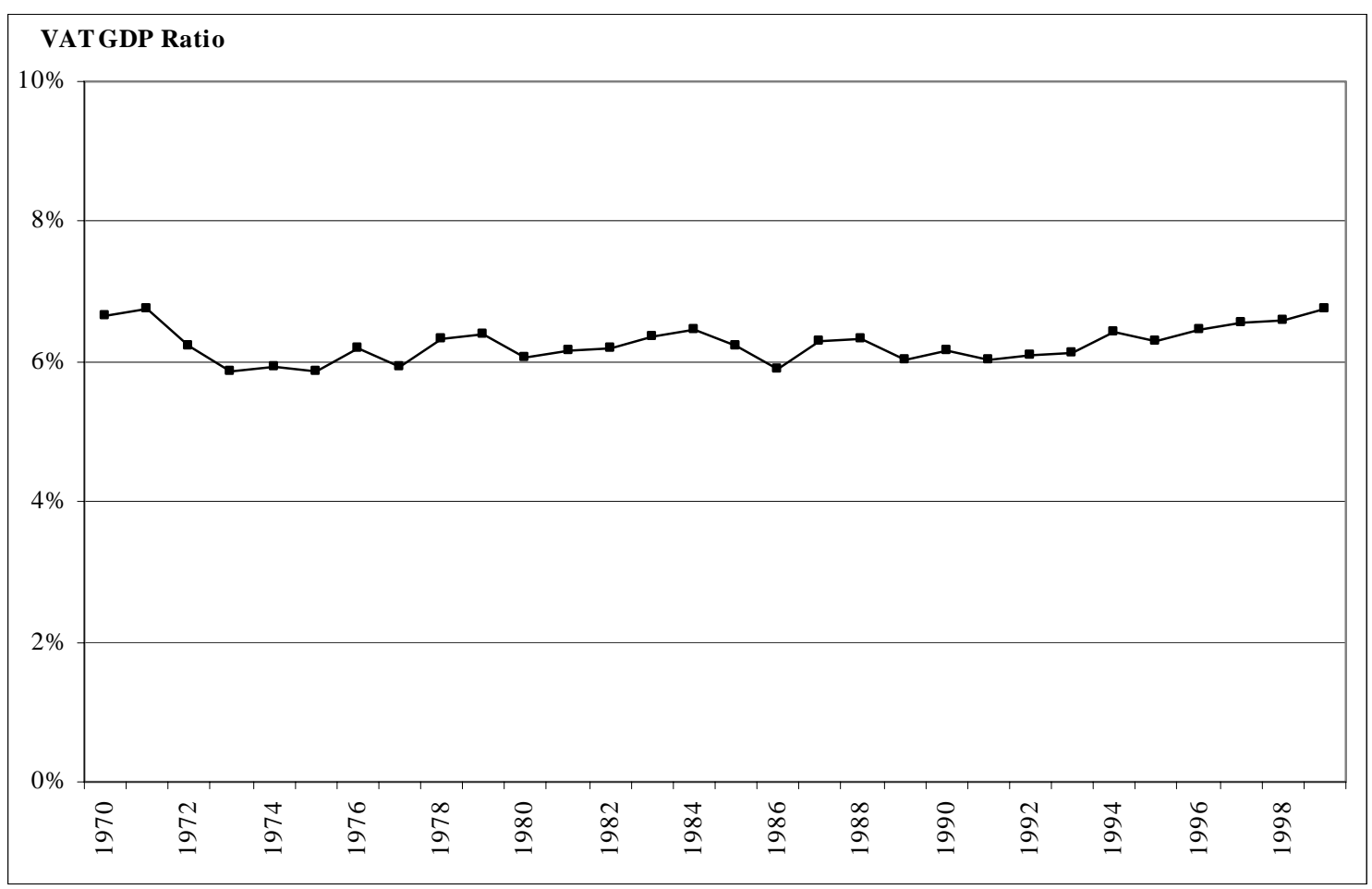

Figure 2.4 shows that for the sample of 25 OECD countries, the VAT ratio is stable around 6 percent until 1990 but has a slightly rising trend during the decade of 
1990s. This ratio at five years interval is presented in Table 2.3. A closer look at country level reveals that this ratio has an increasing trend in 16 of the 25 sample countries; it is stable in 8 countries and is decreasing in one country. ${ }^{6}$ France is the only country in which the ratio is observed to be gradually decreasing but it has not fallen below 7 percent, which is still higher than that of many other countries. Two distinct patterns can be observed in the stable VAT ratio. For the European OECD countries such as Belgium, Czech Republic, Finland, Hungary and Norway, the ratio is stable around 7 percent but for non-European OECD countries such as Canada, Korea and Mexico, it is stable around 3 percent. Japan shows an increasing trend of VAT ratio but it has not exceeded the 5 percent level yet.

\footnotetext{
${ }^{6}$ Graphs for individual countries’ VAT GDP ratios are provided in Appendix II.
} 
Table 2.2 - VAT Share in Total Tax Revenue

\begin{tabular}{|c|c|c|c|c|c|c|c|}
\hline Countries & 1970 & 1975 & 1980 & 1985 & 1990 & 1995 & 1999 \\
\hline Austria & & $19.8 \%$ & $20.1 \%$ & $21.0 \%$ & $20.8 \%$ & $18.2 \%$ & $19.0 \%$ \\
\hline Belgium & & $16.3 \%$ & $17.1 \%$ & $15.7 \%$ & $16.4 \%$ & $15.3 \%$ & $15.9 \%$ \\
\hline Canada & & & & & & $6.6 \%$ & $7.2 \%$ \\
\hline Czech Republic & & & & & & $17.1 \%$ & $18.7 \%$ \\
\hline Denmark & $18.8 \%$ & $16.9 \%$ & $22.3 \%$ & $20.1 \%$ & $18.5 \%$ & $19.3 \%$ & $19.2 \%$ \\
\hline Finland & & & & & & $14.6 \%$ & $16.0 \%$ \\
\hline France & $25.5 \%$ & $23.1 \%$ & $20.9 \%$ & $19.7 \%$ & $18.4 \%$ & $17.0 \%$ & $16.9 \%$ \\
\hline Germany & $17.1 \%$ & $14.6 \%$ & $16.6 \%$ & $15.8 \%$ & $16.6 \%$ & $17.4 \%$ & $18.4 \%$ \\
\hline Greece & & & & & $24.6 \%$ & $22.5 \%$ & $21.1 \%$ \\
\hline Hungary & & & & & & $17.8 \%$ & $21.1 \%$ \\
\hline Ireland & & $14.7 \%$ & $14.7 \%$ & $20.6 \%$ & $20.6 \%$ & $21.2 \%$ & $22.0 \%$ \\
\hline Italy & & $13.7 \%$ & $15.6 \%$ & $14.5 \%$ & $14.7 \%$ & $13.8 \%$ & $13.7 \%$ \\
\hline Japan & & & & & $4.3 \%$ & $5.2 \%$ & $9.6 \%$ \\
\hline Korea & & & $22.0 \%$ & $21.1 \%$ & $20.4 \%$ & $18.9 \%$ & $17.9 \%$ \\
\hline Luxembourg & & $11.9 \%$ & $9.7 \%$ & $10.8 \%$ & $11.6 \%$ & $12.2 \%$ & $14.1 \%$ \\
\hline Mexico & & & $15.6 \%$ & $15.9 \%$ & $20.8 \%$ & $17.0 \%$ & $19.6 \%$ \\
\hline Netherlands & $14.6 \%$ & $14.4 \%$ & $15.8 \%$ & $16.2 \%$ & $16.5 \%$ & $15.6 \%$ & $16.9 \%$ \\
\hline New Zealand & & & & & $22.4 \%$ & $22.7 \%$ & $25.8 \%$ \\
\hline Norway & $23.8 \%$ & $20.5 \%$ & $18.2 \%$ & $18.2 \%$ & $18.8 \%$ & $21.2 \%$ & $21.3 \%$ \\
\hline Poland & & & & & & $17.0 \%$ & $22.8 \%$ \\
\hline Portugal & & & & & $19.6 \%$ & $23.4 \%$ & $23.7 \%$ \\
\hline Spain & & & & & $15.7 \%$ & $15.9 \%$ & $17.5 \%$ \\
\hline Sweden & $10.3 \%$ & $12.0 \%$ & $13.4 \%$ & $14.0 \%$ & $14.9 \%$ & $15.0 \%$ & $13.7 \%$ \\
\hline Turkey & & & & $22.3 \%$ & $18.3 \%$ & $24.3 \%$ & $20.7 \%$ \\
\hline UK & & $8.9 \%$ & $14.7 \%$ & $15.5 \%$ & $17.0 \%$ & $19.3 \%$ & $18.8 \%$ \\
\hline
\end{tabular}

Source: OECD (2001). 
Table 2.3 - VAT GDP Ratio

\begin{tabular}{|c|c|c|c|c|c|c|c|}
\hline Countries & 1970 & 1975 & 1980 & 1985 & 1990 & 1995 & 1999 \\
\hline Austria & & $7.5 \%$ & $8.0 \%$ & $8.8 \%$ & $8.4 \%$ & $7.6 \%$ & $8.4 \%$ \\
\hline Belgium & & $6.7 \%$ & $7.3 \%$ & $7.2 \%$ & $7.1 \%$ & $6.8 \%$ & $7.3 \%$ \\
\hline Canada & & & & & & $2.4 \%$ & $2.7 \%$ \\
\hline Czech Republic & & & & & & $6.9 \%$ & $7.5 \%$ \\
\hline Denmark & $7.6 \%$ & $7.0 \%$ & $9.8 \%$ & $9.5 \%$ & $8.7 \%$ & $9.5 \%$ & $9.7 \%$ \\
\hline Finland & & & & & & $6.5 \%$ & $7.4 \%$ \\
\hline France & $8.9 \%$ & $8.5 \%$ & $8.5 \%$ & $8.6 \%$ & $7.9 \%$ & $7.5 \%$ & $7.8 \%$ \\
\hline Germany & $5.6 \%$ & $5.3 \%$ & $5.5 \%$ & $5.2 \%$ & $5.4 \%$ & $6.7 \%$ & $6.9 \%$ \\
\hline Greece & & & & & $7.2 \%$ & $7.1 \%$ & $7.8 \%$ \\
\hline Hungary & & & & & & $7.6 \%$ & $8.3 \%$ \\
\hline Ireland & & $4.4 \%$ & $4.6 \%$ & $7.2 \%$ & $6.9 \%$ & $7.0 \%$ & $7.1 \%$ \\
\hline Italy & & $3.6 \%$ & $4.8 \%$ & $5.0 \%$ & $5.7 \%$ & $5.7 \%$ & $5.9 \%$ \\
\hline Japan & & & & & $1.3 \%$ & $1.5 \%$ & $2.5 \%$ \\
\hline Korea & & & $3.9 \%$ & $3.6 \%$ & $3.9 \%$ & $3.9 \%$ & $4.2 \%$ \\
\hline Luxembourg & & $4.6 \%$ & $3.9 \%$ & $4.8 \%$ & $4.7 \%$ & $5.1 \%$ & $5.9 \%$ \\
\hline Mexico & & & $2.5 \%$ & $2.7 \%$ & $3.6 \%$ & $2.8 \%$ & $3.3 \%$ \\
\hline Netherlands & $5.4 \%$ & $6.2 \%$ & $6.9 \%$ & $6.9 \%$ & $7.1 \%$ & $6.5 \%$ & $7.1 \%$ \\
\hline New Zealand & & & & & $8.5 \%$ & $8.6 \%$ & $9.2 \%$ \\
\hline Norway & $8.3 \%$ & $8.2 \%$ & $7.8 \%$ & $7.9 \%$ & $7.8 \%$ & $8.8 \%$ & $8.9 \%$ \\
\hline Poland & & & & & & $6.7 \%$ & $8.0 \%$ \\
\hline Portugal & & & & & $5.8 \%$ & $7.6 \%$ & $8.1 \%$ \\
\hline Spain & & & & & $5.2 \%$ & $5.2 \%$ & $6.1 \%$ \\
\hline Sweden & $4.1 \%$ & $5.2 \%$ & $6.4 \%$ & $6.8 \%$ & $8.0 \%$ & $7.1 \%$ & $7.1 \%$ \\
\hline Turkey & & & & $3.5 \%$ & $3.7 \%$ & $5.5 \%$ & $6.5 \%$ \\
\hline UK & & $3.1 \%$ & $5.2 \%$ & $5.8 \%$ & $6.1 \%$ & $6.8 \%$ & $6.8 \%$ \\
\hline
\end{tabular}

Source: OECD, (2001). 


\subsection{Review of the Literature}

Proponents describe the VAT as being self-policing when it is collected through the credit-invoice method (Tait 1972, Cnossen 1987, Shoup 1986). Opponents, on the other hand, dismiss self-policing mechanism of VAT as illusory. Tait (1988) acknowledges, “Like other taxes VAT is evaded” (p. 304) and mentions various ways how a VAT can be evaded. Some of the common examples of VAT evasion are as follows: ${ }^{7}$

i) Firms not registering for VAT: Firms must register for VAT if their yearly turnover or volume of transaction exceeds certain limit - called the VAT threshold - set by the government. If firms' transactions fall below the VAT threshold, firms are generally waived from the requirement to register for VAT. However, as their transactions exceed the limit, and if firms do not register for VAT, the value added by such firms escapes VAT and the government loses revenue.

ii) Overstate refund claims: Firms are allowed to claim VAT paid at earlier stages and one simple way to evade VAT is to overstate such claims.

iii) Understate the sales: Another simple way to evade VAT is to understate the sales - low sales means, firms pay less VAT. This type of evasion is a problem especially at the retail level at which invoices are not issued unless it is requested or issuance of false invoice is quite possible.

iv) Unrecorded cash purchases or barter transactions: If firms are involved in unrecorded cash purchases or barter transactions, then firms are able to sell the

\footnotetext{
${ }^{7}$ For detailed discussion of VAT evasion, see Tait (1988), chapter 14.
} 
goods without charging the VAT. However, this type of VAT evasion is common mainly in developing countries.

v) VAT collected but not remitted to the tax authorities: This type of VAT evasion is especially common in construction industry where small traders collect VAT from their customers but disappear before remitting it to the tax authorities.

vi) Credit claimed for purchases that are not creditable: This type of VAT evasion is possible if a good can be used for multiple purposes. For example, an automobile can be used either for business or for non-business purposes. When it is used for a business purpose, the VAT paid for it is tax deductibles, but when it is used for a non-business purpose, the VAT paid for it is not tax deductibles. Even when the automobile is primarily used for non-business purposes, the business owner will have a strong incentive to claim the VAT credit for his vehicle.

vii) False exports claims or divert zero-rated exports to the domestic market: Another type of VAT evasion is associated with international trade. Firms involved in international business may make completely false export sales and claim for the VAT refund, on the one hand and on the other, they may first obtain necessary documents for exports and claim a VAT refund but later divert their sales to the domestic market.

viii) Goods imported and taxed but sales unreported: Last but not least, VAT evasion is also possible if firms import goods illegally and sell such goods with the full VAT charged. In this type of evasion, firms benefit not only from the 
illegal sale of the goods, but also from the VAT they collect from their costumers because they do not have to remit the VAT so collected to the tax authorities.

Plenty of anecdotal evidences of VAT evasion have also been documented in the literature (see Agha and Haughton 1996; pp. 305, table 2). However, Fedeli and Forte (1999) formally provide theoretical support to the VAT evasion jointly with income tax evasion. Their model involves four agents: manufacturer or importer, wholesaler, retailer and final consumer. If a VAT is levied on consumption, final consumers have the incentive to evade the VAT because this will reduce their gross expenditure in obtaining the same amount of goods and services. Although it may not be intuitive at first why firms and shops, who charge a VAT to their customers, are engaged in evading the VAT, the authors argue, these traders are those leading the chain of evasion. If VAT evasion is considered together with income tax evasion, true reporting of VAT may signal the actual level of income including 'black' transactions. In order to hide income tax and 'black' transaction, therefore, “... each VAT-registered trader in the chain of exchange might find it convenient to accept underreporting of his costs - by reducing the amount of his purchases on invoices - if he, in turn, is able to find purchasers willing to underreport his sales on the invoices. ... a VAT-registered purchaser at any stage may be willing to accept underreporting of his purchases on the invoices, if underreporting increases his gains from (black) trade and thereby compensates him for the likely penalty for tax evasion."8

\footnotetext{
${ }^{8}$ Fedeli and Forte (1999), pp. 395.
} 
There are, however, a few studies which examine the VAT evasion issue empirically. In a cross-sectional study of 17 OECD countries, Agha and Haughton (1996) find that lower VAT compliance is associated with a higher average standard VAT rate, multiple VAT rates and a larger population. They also find that VAT compliance increases along with an increase in administrative expenditure and experience with VAT, that is, an additional year of operation improves VAT compliance by over one percent. Gordon and Neilsen (1997) look at the VAT evasion issue in an open economy setting with particular reference to Denmark and argue that both income taxes and value added taxes are subject to evasion. While income tax is evaded through shifting taxable income abroad, value added tax is evaded through cross-border shopping, if the VAT in home country is based on destination principle. According to the authors, Denmark lost 3.9 billion kroner (or $0.8 \%$ ) of value-added taxation and 14.8 billion (or $4 \%$ ) of labor income taxation in 1992.

In order to examine the VAT non-compliance indicator, the ratio of VAT reclaimed to VAT paid, Matthews and Lloyd-Williams (2001) evaluate selected four sectors of the United Kingdom during 1983 to 1995. They graph this ratio and show a modest upward trend for restaurants and take-outs sector, a flat trend for clothing and footwear sector, a negative trend for furniture and floor-covering sector and a steeply rising trend for the hairdressing sector. An important implication of this study is that more VAT is evaded in the service sector (i.e. hairdressing and restaurants and takeouts) than the goods sector (i.e. clothing and footwear and furniture and floor-covering), possibly because of the fact that the VAT in the service sector is more difficult to monitor 
than in the goods sector. In another study, Nam, Parsche and Schaden (2001) present the measurement of VAT evasion in selected $10 \mathrm{EU}$ countries covering the period from 1994 to 1996 except three countries -- France, Italy and the United Kingdom for which the period covered is from 1991 to 1993 . These authors conclude that Italy, Spain, Greece and Belgium had the highest VAT evasion, but the Netherlands, Denmark and the UK had the lowest VAT evasion and that Germany had the fastest growth of VAT evasion after she entered into the Single Market in 1993. Table 2.4 provides summary information on the VAT evasion literature.

While previous researches have investigated specific issues of VAT evasion for individual countries, none have examined the empirical relationship between reliance on VAT and VAT evasion. Such a relationship can best be investigated using a panel data on countries over time and this study is focused to fill in this gap in the literature. 
Table 2.4 - Summary of Literature Review

\begin{tabular}{|c|c|c|c|}
\hline Authors & Type of Study & Data & Main Results \\
\hline Fedeli and Forte (1999) & Theoretical & - & $\begin{array}{l}\text { - } \quad \text { Provides theoretical support to the VAT evasion jointly with income tax evasion. } \\
\text { - Consumers evade the VAT because this will lower their total expenditure in obtaining the } \\
\text { - In the chain of exchange, manufacturers or importers, wholesalers and retailers are } \\
\text { engaged in VAT evasion in order to hide income tax and black transaction if these agents } \\
\text { find purchasers willing to underreport their purchases on invoices. }\end{array}$ \\
\hline $\begin{array}{l}\text { Agha and Haughton } \\
\text { (1996) }\end{array}$ & Empirical & $\begin{array}{c}\text { 1987; } 17 \\
\text { OECD } \\
\text { Countries }\end{array}$ & $\begin{array}{l}\text { - } \quad \text { A higher VAT rate is associated with lower compliance; } \\
\text { - } \quad \text { A multiple VAT rate is associated with lower compliance; } \\
\text { - } \quad \text { A larger population is associated with lower compliance. } \\
\text { - } \quad \text { The longer the VAT is in place, the higher the VAT compliance. }\end{array}$ \\
\hline $\begin{array}{l}\text { Gordon and Neilson } \\
\text { (1997) }\end{array}$ & Empirical & $\begin{array}{c}\text { 1992; } \\
\text { Denmark }\end{array}$ & $\begin{array}{l}\text { - Income tax is evaded through shifting taxable income abroad. } \\
\text { - Value added tax is evaded through cross-border shopping, if the VAT in home country is } \\
\text { based on destination principle. } \\
\text { In } 1992 \text {, Denmark lost } 3.9 \text { billion kroner (or } 0.8 \% \text { ) of value-added taxation and } 14.8 \\
\text { billion (or } 4 \% \text { ) of labor income taxation. }\end{array}$ \\
\hline $\begin{array}{l}\text { Matthews and Lloyd- } \\
\text { Williams (2001) }\end{array}$ & Empirical & $\begin{array}{c}1983- \\
\text { 1995; UK }\end{array}$ & $\begin{array}{l}\text { - A moderately rising VAT non-compliance ratio for restaurants and rake-outs sector. } \\
\text { - A flat VAT non-compliance ratio for clothing and footwear sector. } \\
\text { - A falling VAT non-compliance ratio for furniture and floor-covering sector. } \\
\text { - } \quad \text { A sharply rising VAT non-compliance ratio for the hairdressing sector. } \\
\text { goods sector. }\end{array}$ \\
\hline $\begin{array}{l}\text { Nam, Parsche and } \\
\text { Schaden (2001) }\end{array}$ & Empirical & $\begin{array}{c}1994- \\
\text { 1996; } 10 \text { EU } \\
\text { Countries }\end{array}$ & $\begin{array}{l}\text { - Italy, Spain, Greece and Belgium had the highest VAT evasion. } \\
\text { - The Netherlands, Denmark and the UK had the lowest VAT evasion. } \\
\text { - Germany had the fastest growth of VAT evasion after she entered into Single Market in } \\
\text { 1993. }\end{array}$ \\
\hline
\end{tabular}




\section{$2.4 \quad$ Theoretical Considerations}

Tax revenue is a function of tax base and tax rate. This simple premise is true for VAT revenue too. In the absence of VAT evasion, in theory, the actual VAT revenue collected by tax authorities exactly equals the potential VAT revenue, which can be obtained by applying the VAT rate to the total VAT Base in the economy. Thus, potential VAT revenue can also be regarded a function of VAT base and VAT rate. Because both potential VAT revenue and actual VAT revenue collected are functions of VAT base and VAT rate, it follows that VAT evasion, the difference between potential VAT and actual VAT, is also a function of VAT base and VAT rate.

As the contribution of a tax gets larger in the tax system, measured in terms of its share in total tax revenue or its ratio to GDP, that particular tax becomes more important to the government. Hence, it makes sense for the government to pay more attention for its better enforcement. This may result in increased tax compliance. At the same time, the reliance on a tax may itself change due to changes in the tax rate and the tax base, which opens up avenues for the tax evasion. In the case of VAT, two sources of change in the tax base can be identified: exogenous and endogenous changes in the tax base. The government can directly add or remove some of the categories from the existing base this is the exogenous change in the tax base. On the other hand, even if the existing tax categories do not change (i.e. tax base is the same from the conventional view point), it is possible that along with the production of the goods and services value added by firms may increase during the phase of economic expansion or decrease during the phase of recession -- this is the endogenous change in the tax base. 
Proponents argue that VAT has a built-in-mechanism to check evasion because an invoice method VAT provides a clear audit trail for investigation. Moreover, Agha and Haughton (1996) offered empirical support that a year of operation increases VAT compliance. Furthermore, it can be argued as the contribution of VAT becomes increasingly important in the tax system, it makes sense for the government to pay more attention for its better enforcement. The combined effects of these facts point in the direction that an increase in reliance on VAT decreases evasion. At the same time, opponents contend that VAT shows a greater tax complexity. It increases the number of taxpayers and of prescribed books of account for each of them, requiring, in general, much paperwork, and it involves a substantial number of refunds. These elements create a greater administrative complexity, which tend to make evasion easier (Leccisotti and Mare, 1992). Additionally, it is also quite possible that a government as an entity with limited resources falls behind to enforce the tax code along with the increase in reliance on the VAT as a result of the greater administrative complexity. The combined effects of these facts point in the opposite direction - an increase in reliance on VAT increases evasion. The arguments in favor and against the VAT allow us a basis to test if there exists any relationship between reliance on VAT and VAT evasion. Table 2.5 summarizes arguments for and against VAT evasion. 


\section{Table 2.5 - VAT Evasion Controversy}

\begin{tabular}{|c|c|c|c|}
\hline & Arguments in Favor: & & Arguments Against: \\
\hline 1. & $\begin{array}{l}\text { A VAT has built-in-mechanism to check evasion. } \\
\text { Sellers have their own interest not to allow the } \\
\text { buyers to cheat by overstating the amount on the } \\
\text { invoice and buyers have their own interest not to } \\
\text { allow the sellers to cheat by understating the } \\
\text { amount on the invoice. }\end{array}$ & 1. & A VAT shows a greater tax complexity. \\
\hline 2. & $\begin{array}{l}\text { An invoice method VAT provides a clear audit } \\
\text { trail for investigation. }\end{array}$ & 2. & $\begin{array}{l}\text { It increases the number of taxpayers and of } \\
\text { prescribed books of account for each of } \\
\text { them, requiring much paper work. }\end{array}$ \\
\hline 3. & $\begin{array}{l}\text { Taxpayers have to claim refunds from the } \\
\text { government and they are unlikely to file } \\
\text { fraudulent refunds because they will be subject to } \\
\text { investigation. }\end{array}$ & 3. & $\begin{array}{l}\text { A VAT involves substantial refunds, which } \\
\text { create great administrative complexity, } \\
\text { which tend to make evasion easier. }\end{array}$ \\
\hline
\end{tabular}

With respect to income tax evasion, the classic seminal work of Allingham and Sandmo (1972) distinguishes between income and substitution effect of a change in the tax rate. As the tax rate increases, so does the gains from evasion on the margin, therefore tax evasion increases -- the substitution effect. On the other hand, tax evasion is a risky affair and if caught, tax authorities not only confiscate the amount of tax evaded but also impose additional penalties as a deterrent of breaching the tax rule, which makes tax payers poorer than in the situation without tax evasion and lower tax rate. Under decreasing absolute risk aversion, this tends to reduce evasion -- the income effect. Therefore, the net effect of an increase in the tax rate on evasion is ambiguous. ${ }^{9}$

\footnotetext{
${ }^{9}$ Yitzhaki (1974) argues that if the penalty on tax evasion is proportional to the evaded tax, rather than to the undeclared income, an increase in the income tax rate must increase declared income because the substitution effect is eliminated. This result is counter-intuitive, however. Subsequently, Yaniv (1994) establishes, theoretically, a negative relationship between declared income and the income tax rate if any of the following two conditions hold: (a) if the penalty rate is $100 \%$, that is, the entire undeclared income is confiscated, or (b) if the relative risk-aversion is constant and bounded from above by the inverse of the penalty rate.
} 
Empirical analyses have also been unable to resolve this controversy. Whereas Clotfelter (1983) and Crane and Nourzad (1989) find a positive relation between marginal tax rates and income tax evasion, Slemrod (1985) and Cox (1984) have questioned such finding claiming no such evidence is present. In the case of indirect tax evasion, Marrelli (1984) shows that under the assumption of monopolistically competitive firms, changes in the tax rate have ambiguous results, even if the fine is imposed on the evaded tax; and under perfect competition Virmani (1989) shows that evasion is positively and production is negatively related to the tax rate. However, these propositions have not been empirically tested yet. With regard to VAT, Agha and Haughton (1996) show that a higher average standard VAT rate is associated with lower compliance. However, they do not generalize their results citing the limitations of the cross-sectional nature of their study which overlooks many other important characteristics of countries. Therefore, further research using alternative methods and sources of data is warranted. Furthermore, Tait (1988, 1991) provides a number of reasons why the multiple rate VAT is more difficult to supervise compared to a single rate VAT. Therefore, multi-rate VAT can be seen to offer an opportunity for a greater VAT evasion.

\section{$2.5 \quad$ Empirical Analysis}

In order to measure the size of tax evasion and underground economy, various methods from direct surveys to sophisticated econometric models have been used in the literature. However, these methods have their own advantages and shortcomings. In this study, I follow Nam, Parsche and Schaden (2001) and compute the difference between the 
potential and actual VAT revenue collected in a given fiscal year in order to determine the extent of VAT evasion in the sample of 25 OECD countries.

My dependent variable, the VAT evasion index, is obtained as follows. ${ }^{10}$ The ratio of actual VAT revenue to potential VAT revenue, also known as the VAT collection performance ratio, has a theoretical maximum of 1 (or 100 expressed as a percent). If we subtract VAT collection performance ratio from 1, we obtain the VAT evasion index. That is,

$$
\text { VAT collection performance ratio }=\frac{\text { Actual VAT Revenue }}{\text { Potential VAT Revenue }} .
$$

Hence,

VAT evasion index $=1-$ VAT collection performance ratio

Note that the actual amount of VAT paid by individual firms is confidential. The VAT evasion index, which takes into account both the potential VAT and the actual VAT, is believed to capture the discrepancy between what firms actually pay in terms of VAT revenue to the tax office and what they report in terms of their gross value added to the National Accounting Office - a different agency than the tax office.

The Value Added Tax in essence is a tax on consumption but it can be calculated in several ways. Total value added in the economy times the applicable VAT rates for a given year gives the potential VAT revenue. In order to calculate the potential VAT revenue, a detailed breakdown of value added along with coverage of different VAT rates to different VAT bases (e.g. reduced rate, higher rate etc.) is necessary. Although value

\footnotetext{
10 The index I use is quite similar to that used by Nam, Parsche and Schaden (2001). Agha and Haughton (1996) use VAT compliance index, which is the same as VAT collection performance ratio that I use here.
} 
added for each country over the years is available, the corresponding rate coverage is not. ${ }^{11}$ Matthews (2003) uses standard VAT rate as a proxy for the representative VAT for the reasons that most VAT-rated goods are taxed at the standard rate and that the correlation between the weighted average rates and standard rate was found to be 0.9181 . Therefore, following Matthews (2003), I also apply only the standard VAT rate. This should give a pretty close estimate of the evasion index; however, I am aware of the imprecision this may introduce into the measurement of the evasion index, which will result in the reduction of the goodness of fit of the regression. The error term will in part pick up the unobserved errors.

In the literature, it has been a standard practice to examine taxes by either looking at changes in the total taxes as a percentage of GDP or percentage of different taxes in total tax revenue (Tosun and Abizadeh, forthcoming). In order to examine the performance of VAT, I use two alternative measures of VAT reliance - VAT Ratio, defined as VAT revenue divided by the GDP and VAT Share, defined as VAT revenue divided by the total tax revenue. Because VAT revenue enters both sides of the regression, I use one year lag of VAT ratio and VAT share in an attempt to correct the potential endogeneity problem caused by it.

My data set is an unbalanced panel with annual data covering the period from 1972 to 1999, a total of 28 years. The starting point for data collection is 1972. I include all countries which introduced a VAT before 1972 except Norway. Although Norway

\footnotetext{
${ }^{11}$ The data on gross value added is obtained from World Development Indicators 2003, which reports the gross value added at factor cost derived as the sum of the value added in the agriculture, industry and services sectors. If value added of these sectors is calculated at purchaser values, total value added is derived by subtracting product taxes from GDP (World Bank 2003).
} 
introduced a VAT in 1970, the data was not available until 1980. So Norway is included only for the period from 1980 to 1999. But all countries did not have a VAT by 1972 . Therefore, during the period 1972 to 1993, I included countries from the year they introduced VAT. There are, however, four exceptions - Canada, Hungary, Korea, and New Zealand. The required data availability was a problem for these countries too. Therefore, data included for Canada and Hungary is from 1991 to 1998; for Korea from 1980 to 1999 and for New Zealand from 1986 to 1996. Descriptions of the variables and data sources can be found in Appendix III. Summary statistics of the variables are presented in Table 2.6. 
Table 2.6 - Summary Statistics

\begin{tabular}{|c|c|c|c|c|c|}
\hline Variables & Observations & Mean & Std. Dev. & Min & Max \\
\hline VAT Evasion Index & 479 & 0.585 & 0.089 & 0.143 & 0.908 \\
\hline VAT Ratio & 479 & 0.062 & 0.019 & 0.01 & 0.1 \\
\hline VAT Share & 479 & 0.169 & 0.041 & 0.033 & 0.261 \\
\hline Standard VAT Rate & 479 & 0.169 & 0.051 & 0.03 & 0.35 \\
\hline Multiple VAT Rate & 479 & 2.764 & 1.461 & 1 & 10 \\
\hline Openness Index & 479 & 0.399 & 0.392 & 0.0001 & 2.108 \\
\hline $\begin{array}{l}\text { Economically Active } \\
\text { Population }\end{array}$ & 479 & 0.660 & 0.049 & 0.522 & 0.889 \\
\hline $\begin{array}{l}\text { Corruption in } \\
\text { Government Index }\end{array}$ & 310 & 1.034 & 1.130 & 0 & 4 \\
\hline VAT Experience & 479 & 12.808 & 8.396 & 0 & 32 \\
\hline
\end{tabular}

\subsection{Empirical Results}

I begin with simple OLS regressions separately on VAT ratio and VAT share as independent variables. Next, I perform regression diagnostics to check for multicollinearity and heteroskedasticity in the data. No multicollinearity problems were detected. Although VAT ratio or VAT share and standard VAT rate are highly correlated, this alone was not sufficient to cause a multicollinearity problem. The matrix of 
correlation coefficients is presented in Appendix IV. However, as expected, a problem of heteroskedasticity was detected in the data. Two possible sources of the heteroskedasticity problem can be identified. First, recall that my data is a panel and panel data are generally plagued with heteroskedasticity. However, heteroskedasticity may also be due to errors in the measurement of the VAT evasion index. The results of the heteroskedasticity tests are presented in Appendix V.

In order to correct the problem of heteroskedasticity, I run GLS model. The regression results for the VAT ratio and the VAT share are presented in Table 2.7a and Table 2.7b respectively. Furthermore, since my data set is a panel data, I use country dummies and year dummies to capture any country and time specific effects and run fixed effects and random effects models. Although Hausman test suggests that the fixed effects model is preferred to the random effects model $\left(\chi^{2}(28)=146.70\right)$, I also present results from alternative random effects model. ${ }^{12}$ The results presented in Table 2.7a in columns (1), (2), (3) and (4) are qualitatively quite similar to that of Table 2.7b. Coefficients of both variables VAT ratio and VAT share are negative and significant at one percent level, which can be interpreted to suggest that as these measures of VAT reliance increase, i.e. the VAT ratio and the VAT share increase, VAT evasion decreases. Similarly, the coefficient of standard VAT rate is positive and significant at one percent level, which can be interpreted to suggest that as the standard VAT rate increases, VAT

\footnotetext{
${ }^{12}$ The parameter estimates obtained from fixed effects model are consistent under $H_{0}$ and $H_{a}$. The parameter estimates obtained from random effects model are inconsistent under $H_{a}$ but efficient under $H_{0}$. I perform the Hausman test of the null hypothesis that the difference in coefficients obtained from both fixed effects and random effects models are not systematic. The test statistics suggest that we reject the null hypothesis.
} 
evasion also increases. Although the coefficient of multiple VAT rate is significant except in fixed effects model in these two tables, later I show that the results are no longer robust. Therefore, no definitive conclusion about the relationship between multiple VAT rate and the VAT evasion can be made.

Table 2.7a - Regression Results for VAT Ratio as Independent variable

\begin{tabular}{|c|c|c|c|c|}
\hline $\begin{array}{l}\text { VAT Evasion Index } \\
\text { Dependent Variable }\end{array}$ & Pooled OLS & GLS & Fixed Effects & $\begin{array}{c}\text { Random } \\
\text { Effects }\end{array}$ \\
\hline & $(1)$ & (2) & (3) & (4) \\
\hline Log of VAT Ratio ${ }_{t-1}$ & $\begin{array}{l}-.556^{* * *} \\
(26.05)\end{array}$ & $\begin{array}{l}-.556 * \text { ** } \\
(26.17)\end{array}$ & $\begin{array}{l}-.291^{* * *} \\
(13.54)\end{array}$ & $\begin{array}{c}-.403^{* * *} \\
(17.25)\end{array}$ \\
\hline $\begin{array}{l}\text { Log of Standard VAT } \\
\text { Rate }\end{array}$ & $\begin{array}{l}.546^{* * *} \\
(23.18)\end{array}$ & $\begin{array}{l}.546^{* * *} \\
(23.28)\end{array}$ & $\begin{array}{l}.355^{* * *} \\
(11.78)\end{array}$ & $\begin{array}{l}.425^{* * *} \\
(15.91)\end{array}$ \\
\hline $\begin{array}{l}\text { Log of Number of } \\
\text { Multiple VAT Rate }\end{array}$ & $\begin{array}{l}.045^{* * *} \\
(4.80)\end{array}$ & $\begin{array}{l}.045^{* * *} \\
(4.82)\end{array}$ & $\begin{array}{l}-.0002 \\
(0.02)\end{array}$ & $\begin{array}{l}.034 * * * \\
(2.64)\end{array}$ \\
\hline Constant & $\begin{array}{l}-1.179^{* * *} \\
(31.54)\end{array}$ & $\begin{array}{l}-1.179^{* * *} \\
(31.68)\end{array}$ & $\begin{array}{l}-.748^{* * *} \\
(12.30)\end{array}$ & $\begin{array}{c}-.967^{* * *} \\
(19.15)\end{array}$ \\
\hline $\mathrm{R}^{2}$ & 0.646 & & 0.578 & 0.645 \\
\hline Sample size & 454 & 454 & 454 & 454 \\
\hline
\end{tabular}

Note:

(1) Figures in parenthesis are t-statistics if OLS and fixed effects model and they are zstatistics if GLS or random effects model.

(2) $\quad * * *$ indicate 1 percent significance level. **indicate 5 percent significance level. *indicate 10 percent significance level. 
Table 2.7b - Regression Results for VAT Share as Independent variable

\begin{tabular}{|c|c|c|c|c|}
\hline $\begin{array}{l}\text { VAT Evasion Index } \\
\text { Dependent Variable }\end{array}$ & Pooled OLS & $G L S$ & Fixed Effects & $\begin{array}{l}\text { Random } \\
\text { Effects }\end{array}$ \\
\hline & (1) & (2) & (3) & (4) \\
\hline Log of VAT Share ${ }_{t-1}$ & $\begin{aligned}-.251^{* * *} & (8.66)\end{aligned}$ & $\begin{array}{l}-.251 * * * \\
(8.70)\end{array}$ & $\begin{array}{c}-.224 * * * \\
(9.88)\end{array}$ & $\begin{array}{l}-.230 * * * \\
(10.00)\end{array}$ \\
\hline $\begin{array}{l}\text { Log of Standard VAT } \\
\text { Rate }\end{array}$ & $\begin{array}{l}.174 * \star \star \\
(7.00)\end{array}$ & $\begin{array}{l}.174 * * * \\
(7.03)\end{array}$ & $\begin{array}{l}.310 * \star * \\
(9.61)\end{array}$ & $\begin{array}{l}.287 * \star \star \\
(9.77)\end{array}$ \\
\hline $\begin{array}{l}\text { Log of Number of } \\
\text { Multiple VAT Rate }\end{array}$ & $\begin{array}{l}.078 * * * \\
(5.73)\end{array}$ & $\begin{array}{l}.078 * * * \\
(5.75)\end{array}$ & $\begin{array}{c}.002 \\
(0.13)\end{array}$ & $\begin{array}{l}.009 \\
(0.62)\end{array}$ \\
\hline Constant & $\begin{array}{l}-.761^{* * *} \\
(15.74)\end{array}$ & $\begin{array}{l}-.761 * * * \\
(15.81)\end{array}$ & $\begin{array}{c}-.428 * * * \\
(7.72)\end{array}$ & $\begin{aligned}-.484 * * * \\
(8.49)\end{aligned}$ \\
\hline $\mathrm{R}^{2}$ & $\odot .239$ & & 0.142 & 0.161 \\
\hline Sample size & 454 & 454 & 454 & 454 \\
\hline
\end{tabular}

Note:

(1) Figures in parenthesis are t-statistics if OLS and fixed effects model and they are zstatistics if GLS or random effects model.

(2) $\quad * * *$ indicate 1 percent significance level. **indicate 5 percent significance level. *indicate 10 percent significance level.

\subsubsection{Robustness Check of the Results}

To check the robustness of the results, in this section I include other variables of interest in my regressions that could potentially affect the VAT evasion. I use openness index as control variable to capture spillover effect of the openness of a country. The openness index, defined as the ratio of the sum of exports and imports to the GDP, measures the trade volume of a country in terms of GDP. The more open a country is, the more goods and services are traded with other countries. In case of exports as they leave the country and in the case of imports as they enter the country, goods and services are reported to the government. This may break the chain of 'illegal' transactions, if existed any, making it 
more difficult to evade the VAT. However, an increase in the trade volume may also provide new avenues of VAT evasion for firms involved in export and import business. (See points (vii) and (viii) of the examples of VAT evasion on page 15-17.) Therefore, a priori, openness index has an ambiguous effect on the VAT evasion.

With respect to income tax evasion, several survey studies have attempted to associate the propensity to evade taxes with certain demographic characteristics. Spicer and Lundstedt (1976) and Vogel (1974) found that older people are less likely to evade taxes than younger people. However, Song and Yarbrough (1978) found that taxpayers aged 40 to 65 years are the least likely to evade while people in younger and older generations are more likely to evade. In the case of VAT, again Agha and Houghton (1996) found that a larger population is associated with lower compliance, possibly for the reason that it is difficult for the tax authorities to cross-examine a large number of populations, which reduces the probability of being caught. Because VAT evasion as such is possible only by economically active population, I use share of economically active population as another control variable to capture this effect. The results are presented in Tables 2.8a and 2.8b. 
Table 2.8a - Regression Results for VAT Ratio as Independent variable

\begin{tabular}{|c|c|c|c|c|}
\hline $\begin{array}{l}\text { VAT Evasion Index } \\
\text { Dependent Variable }\end{array}$ & Pooled OLS & GLS & Fixed Effects & $\begin{array}{l}\text { Random } \\
\text { Effects }\end{array}$ \\
\hline & (1) & $(2)$ & (3) & (4) \\
\hline Log of VAT Ratio ${ }_{t-1}$ & $\begin{array}{l}-.583 * \star * \\
(26.19)\end{array}$ & $\begin{array}{l}-.583 * * * \\
(26.36)\end{array}$ & $\begin{array}{l}-.295^{* * *} \\
(13.89)\end{array}$ & $\begin{array}{c}-.403 * * * \\
(17.25)\end{array}$ \\
\hline $\begin{array}{l}\text { Log of Standard VAT } \\
\text { Rate }\end{array}$ & $\begin{array}{l}.575 * * * \\
(23.03)\end{array}$ & $\begin{array}{l}.575 * * * \\
(23.18)\end{array}$ & $\begin{array}{l}.374 * * * \\
(12.36)\end{array}$ & $\begin{array}{l}.433^{* * *} \\
(15.94)\end{array}$ \\
\hline $\begin{array}{l}\text { Log of Number of } \\
\text { Multiple VAT Rate }\end{array}$ & $\begin{array}{l}.057 * * * \\
(4.97)\end{array}$ & $\begin{array}{l}.057 * \star * \\
(5.00)\end{array}$ & $\begin{array}{c}-.003 \\
(0.24)\end{array}$ & $\begin{array}{l}.035^{* *} \\
(2.49)\end{array}$ \\
\hline $\begin{array}{l}\text { Log of Openness } \\
\text { Index }\end{array}$ & $\begin{array}{c}.003 \\
(1.13)\end{array}$ & $\begin{array}{c}.003 \\
(1.14)\end{array}$ & $\begin{array}{l}.058^{\star} \\
(1.67)\end{array}$ & $\begin{array}{l}.000 \\
(0.2)\end{array}$ \\
\hline $\begin{array}{l}\text { Log of Economically } \\
\text { Active Population }\end{array}$ & $\begin{array}{l}.319 * * * \\
(4.21)\end{array}$ & $\begin{array}{l}319 * * * \\
(4.24)\end{array}$ & $\begin{array}{l}.242 * * * \\
(2.81)\end{array}$ & $\begin{array}{l}.234^{*} \\
(2.54)\end{array}$ \\
\hline Constant & $\begin{array}{c}-1.075 * * * \\
(24.21)\end{array}$ & $\begin{array}{c}-1.075^{* * *} \\
(24.37)\end{array}$ & $\begin{array}{l}-.516 * * * \\
(5.29)\end{array}$ & $\begin{array}{l}-.860 * * * \\
(13.65)\end{array}$ \\
\hline $\mathrm{R}^{2}$ & 0.659 & & 0.106 & 0.659 \\
\hline Sample size & 454 & 454 & 454 & 454 \\
\hline
\end{tabular}

Note:

(1) Figures in parenthesis are t-statistics if OLS and fixed effects model and they are zstatistics if GLS or random effects model.

(2) $\quad * * *$ indicate 1 percent significance level. **indicate 5 percent significance level. *indicate 10 percent significance level. 
Table 2.8b - Regression Results for VAT Share as Independent variable

\begin{tabular}{|c|c|c|c|c|}
\hline $\begin{array}{l}\text { VAT Evasion Index } \\
\text { Dependent Variable }\end{array}$ & Pooled OLS & $G L S$ & Fixed Effects & $\begin{array}{c}\text { Random } \\
\text { Effects }\end{array}$ \\
\hline & (1) & (2) & (3) & (4) \\
\hline Log of VAT Share $t-1$ & $\begin{array}{l}-.255^{* * *} \\
(8.83)\end{array}$ & $\begin{array}{l}-.255^{* * *} \\
(8.88)\end{array}$ & $\begin{array}{l}-.227^{* * *} \\
(10.09)\end{array}$ & $\begin{array}{l}-.229 * * * \\
(10.01)\end{array}$ \\
\hline $\begin{array}{l}\text { Log of Standard VAT } \\
\text { Rate }\end{array}$ & $\begin{array}{l}.163 * * * \\
(6.45)\end{array}$ & $\begin{array}{l}.163 * * * \\
(6.49)\end{array}$ & $\begin{array}{l}.326 * * * \\
(10.05)\end{array}$ & $\begin{array}{l}.296 * * * \\
(9.93)\end{array}$ \\
\hline $\begin{array}{l}\text { Log of Number of } \\
\text { Multiple VAT Rate }\end{array}$ & $\begin{array}{l}.080 * * * \\
(4.73)\end{array}$ & $\begin{array}{l}.080 * * * \\
(4.76)\end{array}$ & $\begin{array}{l}-.002 \\
(0.15)\end{array}$ & $\begin{array}{c}.009 \\
(0.63)\end{array}$ \\
\hline $\begin{array}{l}\text { Log of Openness } \\
\text { Index }\end{array}$ & $\begin{array}{l}.004 \\
(1.06)\end{array}$ & $\begin{array}{l}.004 \\
(1.07)\end{array}$ & $\begin{array}{l}.072^{*} \\
(1.91)\end{array}$ & $\begin{array}{c}.001 \\
(0.09)\end{array}$ \\
\hline $\begin{array}{l}\text { Log of Economically } \\
\text { Active Population }\end{array}$ & $\begin{array}{c}-.369 * * * \\
(3.46)\end{array}$ & $\begin{array}{c}-.370 * * * \\
(3.48)\end{array}$ & $\begin{array}{l}.184^{*} \\
(1.98)\end{array}$ & $\begin{array}{l}.162^{*} \\
(1.72)\end{array}$ \\
\hline Constant & $\begin{array}{l}-.936 * * * \\
(13.88)\end{array}$ & $\begin{array}{c}-.936 * * * \\
(13.97)\end{array}$ & $\begin{array}{l}-.189 * \\
(1.87)\end{array}$ & $\begin{aligned} &-.400 * * * \\
&(5.29)\end{aligned}$ \\
\hline $\mathrm{R}^{2}$ & 0.266 & & $\odot .017$ & 0.138 \\
\hline Sample size & 454 & 454 & 454 & 454 \\
\hline
\end{tabular}

Note:

(1) Figures in parenthesis are t-statistics if OLS and fixed effects model and they are zstatistics if GLS or random effects model.

(2) $\quad * * *$ indicate 1 percent significance level. ${ }^{* *}$ indicate 5 percent significance level. *indicate 10 percent significance level.

The results show that the coefficient of openness index is always positive but significant only at 10 percent level for fixed effects results. This suggests there is some indication that firms' VAT evading activities outweigh government's cross-checking activities. Similarly, the coefficient of economically active population is found to be positive and significant in virtually all cases at one percent level when VAT ratio is independent variable and positive and significant at five percent level for fixed effects model when VAT share is independent variable. This can be interpreted there is very 
strong evidence that an increase in economically active population increases VAT evasion.

For a further check of the robustness of the results, I include corruption in government index and VAT experience variables and run the regressions for the subset of data from 1982 to 1997 . Corruption in government index is a continuous variable, which can range from 0 to 6 . A value close to 0 indicates a cleaner government and a value close to 6 indicates a rampant corruption in government. ${ }^{13}$ Similarly, the VAT experience variable is expected to capture the experience of VAT in a country over time. This variable varies from zero to 32. It is zero the year a VAT is introduced in a country. For some countries the VAT was introduced before 1972, so this variable takes the value of how many years elapsed by 1972. For example, the VAT was introduced in Denmark in 1967, so this variable for Denmark in 1972 is five and it increases by one with the year thereafter. The fixed effects results are presented in Table 2.9a and Table 2.9b for VAT ratio and VAT share respectively. Alternative results from random effects model are presented in Appendix VIa and Appendix VIb.

The results show that the coefficient of corruption in government is always positive but significant only at 10 percent level when the VAT share is the main independent variable. This can be interpreted to suggest that there is some indication as corruption in the government increases, VAT evasion also increases. Likewise, in the full model when VAT ratio and VAT share variables are the main independent variable, the

\footnotetext{
13 The original value of the corruption in government ranges from 0 to 6 . A value close to 0 indicates a rampant corruption in government and a value close to 6 indicates a cleaner government. In order to make the econometric results consistent with the dependent variables used in the regression, I transform this variable by subtracting the original values from 6 . Running the regression with the original values does not change the interpretation of the results. The results are available from me upon request.
} 
VAT experience variable is not significant. But when the corruption in government variable is dropped, the VAT experience variable becomes negative and significant at 10 percent level. This can be interpreted to suggest that the VAT experience variable is sensitive and that there is some indication as countries become more experienced with the VAT, VAT evasion decreases.

Table 2.9a - Sensitivity Analysis Results (VAT Ratio as independent variables)

\begin{tabular}{|c|c|c|c|}
\hline $\begin{array}{l}\text { VAT Evasion Index } \\
\text { Dependent Variable }\end{array}$ & $\begin{array}{c}\text { Full } \\
\text { Model }\end{array}$ & $\begin{array}{c}\text { Without } \\
\text { VAT Experience }\end{array}$ & $\begin{array}{c}\text { Without } \\
\text { Corruption in } \\
\text { Government Index }\end{array}$ \\
\hline & (1) & (2) & (3) \\
\hline Log of VAT Ratio ${ }_{t-1}$ & $\begin{array}{c}-.309 * * * \\
(9.79)\end{array}$ & $\begin{array}{l}-.309 * * * \\
(9.79)\end{array}$ & $\begin{array}{l}-.295 * * * \\
(13.93)\end{array}$ \\
\hline $\begin{array}{l}\text { Log of Standard VAT } \\
\text { Rate }\end{array}$ & $\begin{array}{l}.399 * * * \\
(9.26)\end{array}$ & $\begin{array}{l}.399 * * * \\
(9.26)\end{array}$ & $\begin{array}{l}.374 * * * \\
(12.41)\end{array}$ \\
\hline $\begin{array}{l}\text { Log of Number of } \\
\text { Multiple VAT Rate }\end{array}$ & $\begin{array}{l}-.030^{*} \\
(1.65)\end{array}$ & $\begin{array}{l}-.030^{*} \\
(1.65)\end{array}$ & $\begin{array}{l}-.003 \\
(0.23)\end{array}$ \\
\hline Log of Openness Index & $\begin{array}{l}.081^{\star} \\
(1.68)\end{array}$ & $\begin{array}{l}.081^{\star} \\
(1.68)\end{array}$ & $\begin{array}{c}.057 \\
(1.64)\end{array}$ \\
\hline $\begin{array}{l}\text { Log of Economically } \\
\text { Active Population }\end{array}$ & $\begin{array}{l}-.501^{\star} \\
(1.74)\end{array}$ & $\begin{array}{l}-.501^{\star} \\
(1.74)\end{array}$ & $\begin{array}{l}.243 * \star \star \\
(2.83)\end{array}$ \\
\hline VAT Experience & $\begin{array}{l}0.000 \\
(0.00)\end{array}$ & & $\begin{array}{l}-.033^{*} \\
(1.91)\end{array}$ \\
\hline $\begin{array}{l}\text { Log of Corruption in } \\
\text { Government Index }\end{array}$ & $\begin{array}{c}.008 \\
(1.06)\end{array}$ & $\begin{array}{c}.008 \\
(1.06)\end{array}$ & \\
\hline Constant & $\begin{array}{c}-.746 * \star * \\
(4.08)\end{array}$ & $\begin{array}{c}-.746 * * * \\
(4.22)\end{array}$ & $\begin{array}{c}.256 \\
(0.62)\end{array}$ \\
\hline $\mathrm{R}^{2}$ & $\odot .053$ & 0.053 & $\odot . \odot 2 \odot$ \\
\hline Sample size & 298 & 298 & 454 \\
\hline Model & Fixed Effect & Fixed Effect & Fixed Effect \\
\hline
\end{tabular}

Note: (1) Figures in parenthesis show t-statistics.

(2) $\quad * * *$ indicate 1 percent significance level. **indicate 5 percent significance level. *indicate 10 percent significance level. 
Table 2.9b - Sensitivity Analysis Results (VAT Share as independent variables)

\begin{tabular}{|c|c|c|c|}
\hline $\begin{array}{l}\text { VAT Evasion Index } \\
\text { Dependent Variable }\end{array}$ & $\begin{array}{c}\text { Full } \\
\text { Model }\end{array}$ & $\begin{array}{l}\text { Without VAT } \\
\text { Experience } \\
\text { Dummy }\end{array}$ & $\begin{array}{c}\text { Without } \\
\text { Corruption in } \\
\text { Government Index }\end{array}$ \\
\hline & (1) & $(2)$ & (3) \\
\hline Log of VAT Share $_{\mathrm{t}-1}$ & $\begin{array}{c}-.252^{* \star \star} \\
(7.41)\end{array}$ & $\begin{array}{c}-.252 * \star \star \\
(7.41)\end{array}$ & $\begin{array}{l}-.227 * * * \\
(10.11)\end{array}$ \\
\hline $\begin{array}{l}\text { Log of Standard VAT } \\
\text { Rate }\end{array}$ & $\begin{array}{l}.357 * * \star \\
(7.89)\end{array}$ & $\begin{array}{l}.357 * * * \\
(7.89)\end{array}$ & $\begin{array}{l}.326 * * * \\
(10.09)\end{array}$ \\
\hline $\begin{array}{l}\text { Log of Number of } \\
\text { Multiple VAT Rate }\end{array}$ & $\begin{array}{l}-.037^{\star} \\
(1.95)\end{array}$ & $\begin{array}{l}-.037^{\star} \\
(1.95)\end{array}$ & $\begin{array}{l}-.002 \\
(0.15)\end{array}$ \\
\hline Log of Openness Index & $\begin{array}{l}.102 * * \\
(1.97)\end{array}$ & $\begin{array}{l}.102 * * \\
(1.97)\end{array}$ & $\begin{array}{l}.072^{*} \\
(1.89)\end{array}$ \\
\hline $\begin{array}{l}\text { Log of Economically } \\
\text { Active Population }\end{array}$ & $\begin{array}{l}-.750^{* *} \\
(2.45)\end{array}$ & $\begin{array}{l}-.750 * * \\
(2.45)\end{array}$ & $\begin{array}{l}.186^{*} * \\
(2.00)\end{array}$ \\
\hline VAT Experience & $\begin{array}{l}-.001 \\
(0.70)\end{array}$ & & $\begin{array}{l}-.033^{*} \\
(1.76)\end{array}$ \\
\hline $\begin{array}{l}\text { Corruption in } \\
\text { Government Index }\end{array}$ & $\begin{array}{l}.014^{\star} \\
(1.70)\end{array}$ & $\begin{array}{l}.014^{\star} \\
(1.70)\end{array}$ & \\
\hline Constant & $\begin{array}{l}-.443^{* *} \\
(2.36)\end{array}$ & $\begin{array}{l}-.450 * * \\
(2.49)\end{array}$ & $\begin{array}{c}.584 \\
(1.30)\end{array}$ \\
\hline $\mathrm{R}^{2}$ & $\odot .010$ & 0.011 & $\odot .003$ \\
\hline Sample size & 298 & 298 & 454 \\
\hline Model & Fixed Effect & Fixed Effect & Fixed Effect \\
\hline
\end{tabular}

Note: (1) Figures in parenthesis show t-statistics.

(2) $\quad * * *$ indicate 1 percent significance level. $* *$ indicate 5 percent significance level. *indicate 10 percent significance level. 
Furthermore, I conduct the sensitivity analysis by omitting some of the control variables from the regression one at a time. The sensitivity analysis results from the fixed effects model for the two independent variables - VAT ratio and VAT share - are presented separately in Tables 2.10a and 2.10b. Alternative results from random effects model are presented in Appendix VIIa and Appendix VIIb. Overall, the full model regression results are quite robust to the omission of the variables. Both the main independent variables - VAT ratio and VAT share - are consistently significant at one percent significance level in all cases. Moreover, except main independent variables and standard VAT rate, the magnitudes of estimates of main independent variables and the magnitudes of estimates of standard VAT rate are quite similar to their respective full regression model. In the case when the standard VAT rate, VAT ratio or VAT share are dropped from the regression, the magnitudes of estimates of both of the main independent variables or standard VAT rate are lower than their respective base regression estimates. 
Table 2.10a - Sensitivity Analysis Results (VAT Ratio as independent variable)

\begin{tabular}{|c|c|c|c|c|c|c|}
\hline $\begin{array}{l}\text { VAT Evasion Index } \\
\text { Dependent Variable }\end{array}$ & $\begin{array}{l}\text { Full } \\
\text { Model }\end{array}$ & $\begin{array}{l}\text { Without } \\
\text { Vat Ratio }\end{array}$ & $\begin{array}{l}\text { Without } \\
\text { Standard } \\
\text { VAT Rate }\end{array}$ & $\begin{array}{c}\text { Without } \\
\text { Multiple VAT } \\
\text { Rate }\end{array}$ & $\begin{array}{l}\text { Without } \\
\text { Openness } \\
\text { Index }\end{array}$ & $\begin{array}{c}\text { Without } \\
\text { Economically } \\
\text { Active } \\
\text { Population } \\
\end{array}$ \\
\hline & (1) & $(2)$ & (3) & (4) & (5) & $(6)$ \\
\hline Log of VAT Ratio ${ }_{t-1}$ & $\begin{array}{l}-.295^{* * *} \\
(13.89)\end{array}$ & & $\begin{array}{l}-.188^{* * *} \\
(8.24)\end{array}$ & $\begin{array}{l}-.295^{* * *} \\
(13.92)\end{array}$ & $\begin{array}{l}-.293^{* * *} \\
(13.80)\end{array}$ & $\begin{array}{l}-.293^{* * *} \\
(13.68)\end{array}$ \\
\hline $\begin{array}{l}\text { Log of Standard VAT } \\
\text { Rate }\end{array}$ & $\begin{array}{l}.374 * * * \\
(12.36)\end{array}$ & $\begin{array}{l}126 * \star * \\
(3.22)\end{array}$ & & $\begin{array}{l}.375 * * * \\
(12.42)\end{array}$ & $\begin{array}{l}.370 * * * \\
(12.24)\end{array}$ & $\begin{array}{l}.362 * * * \\
(11.98)\end{array}$ \\
\hline $\begin{array}{l}\text { Log of Number of } \\
\text { Multiple VAT Rate }\end{array}$ & $\begin{array}{c}-.003 \\
(0.24)\end{array}$ & $\begin{array}{c}.004 \\
(0.18)\end{array}$ & $\begin{array}{l}-.015 \\
(0.91)\end{array}$ & & $\begin{array}{c}.001 \\
(0.06)\end{array}$ & $\begin{array}{l}-.005 \\
(0.38)\end{array}$ \\
\hline Log of Openness Index & $\begin{array}{l}.058 * \\
(1.67)\end{array}$ & $\begin{array}{c}-.021 \\
(0.47)\end{array}$ & $\begin{array}{c}.024 \\
(0.58)\end{array}$ & $\begin{array}{l}.057^{\star} \\
(1.66)\end{array}$ & & $\begin{array}{l}.072 * * \\
(2.06)\end{array}$ \\
\hline $\begin{array}{l}\text { Log of Economically } \\
\text { Active Population }\end{array}$ & $\begin{array}{l}.242 * * * \\
(2.81)\end{array}$ & $\begin{array}{c}.098 \\
(0.75)\end{array}$ & $\begin{array}{c}.089 \\
(0.89)\end{array}$ & $\begin{array}{l}.243 * * * \\
(2.83)\end{array}$ & $\begin{array}{l}.262 * * * \\
(3.06)\end{array}$ & \\
\hline Constant & $\begin{array}{l}-.516 * * * \\
(5.29)\end{array}$ & $\begin{array}{l}-.345^{* * *} \\
(3.03)\end{array}$ & $\begin{array}{l}-.985 * * * \\
(9.32)\end{array}$ & $\begin{array}{l}-.520 * * * \\
(5.40)\end{array}$ & $\begin{array}{l}-.626 * * * \\
(8.66)\end{array}$ & $\begin{array}{l}-.602 * * * \\
(6.44)\end{array}$ \\
\hline $\mathrm{R}^{2}$ & 0.106 & $\odot .017$ & $\odot .029$ & $\odot .114$ & $\odot .571$ & $\odot .075$ \\
\hline Sample size & 454 & 479 & 454 & 454 & 454 & 454 \\
\hline Model & Fixed Effects & Fixed Effects & Fixed Effects & Fixed Effects & Fixed Effects & Fixed Effects \\
\hline
\end{tabular}

Note: (1) Figures in parenthesis show z-statistics.

(2) ***indicate 1 percent significance level. **indicate 5 percent significance level. *indicate 10 percent significance level. 
Table 2.10b - Sensitivity Analysis Results

(VAT Share as independent variable)

\begin{tabular}{|c|c|c|c|c|c|c|}
\hline $\begin{array}{l}\text { VAT Evasion Index } \\
\text { Dependent Variable }\end{array}$ & $\begin{array}{l}\text { Full } \\
\text { Model }\end{array}$ & $\begin{array}{l}\text { Without } \\
\text { Vat Ratio }\end{array}$ & $\begin{array}{l}\text { Without } \\
\text { Standard } \\
\text { VAT Rate }\end{array}$ & $\begin{array}{c}\text { Without } \\
\text { Multiple VAT } \\
\text { Rate }\end{array}$ & $\begin{array}{l}\text { Without } \\
\text { Openness } \\
\text { Index }\end{array}$ & $\begin{array}{c}\text { Without } \\
\text { Economically } \\
\text { Active } \\
\text { Population } \\
\end{array}$ \\
\hline & (1) & $(2)$ & (3) & (4) & (5) & $(6)$ \\
\hline Log of VAT Share ${ }_{t-1}$ & $\begin{array}{l}-.227^{* * *} \\
(10.09)\end{array}$ & & $\begin{array}{l}-.142 * * * \\
(6.07)\end{array}$ & $\begin{array}{l}-.227^{* * *} \\
(10.12)\end{array}$ & $\begin{array}{l}-.223^{* * *} \\
(9.93)\end{array}$ & $\begin{array}{l}-.228^{* * *} \\
(10.08)\end{array}$ \\
\hline $\begin{array}{l}\text { Log of Standard VAT } \\
\text { Rate }\end{array}$ & $\begin{array}{l}.326 * * * \\
(10.05)\end{array}$ & $\begin{array}{l}126 * \star * \\
(3.22)\end{array}$ & & $\begin{array}{l}.326 * * * \\
(10.10)\end{array}$ & $\begin{array}{l}.320 * * * \\
(9.88)\end{array}$ & $\begin{array}{l}.318 * \star * \\
(9.85)\end{array}$ \\
\hline $\begin{array}{l}\text { Log of Number of } \\
\text { Multiple VAT Rate }\end{array}$ & $\begin{array}{c}-.002 \\
(0.15)\end{array}$ & $\begin{array}{c}.003 \\
(0.18)\end{array}$ & $\begin{array}{c}-.012 \\
(0.74)\end{array}$ & & $\begin{array}{c}.003 \\
(0.20)\end{array}$ & $\begin{array}{c}-.003 \\
(0.26)\end{array}$ \\
\hline Log of Openness Index & $\begin{array}{l}.073^{*} \\
(1.91)\end{array}$ & $\begin{array}{c}-.021 \\
(0.47)\end{array}$ & $\begin{array}{c}.035 \\
(0.84)\end{array}$ & $\begin{array}{l}.072^{\star} \\
(1.92)\end{array}$ & & $\begin{array}{l}.083^{*} * \\
(2.21)\end{array}$ \\
\hline $\begin{array}{l}\text { Log of Economically } \\
\text { Active Population }\end{array}$ & $\begin{array}{l}.185^{*} * \\
(1.98)\end{array}$ & $\begin{array}{c}.098 \\
(0.75)\end{array}$ & $\begin{array}{c}.067 \\
(0.65)\end{array}$ & $\begin{array}{l}.185^{* *} \\
(1.99)\end{array}$ & $\begin{array}{l}.210 * * \\
(2.26)\end{array}$ & \\
\hline Constant & $\begin{array}{l}-.189^{*} \\
(1.87)\end{array}$ & $\begin{array}{l}-.344 * * * \\
(3.03)\end{array}$ & $\begin{array}{l}-.709 * * * \\
(7.32)\end{array}$ & $\begin{array}{l}-.192^{*} \\
(1.93)\end{array}$ & $\begin{array}{l}-.326 * * * \\
(4.57)\end{array}$ & $\begin{array}{l}-.257 * * * \\
(2.70)\end{array}$ \\
\hline $\mathrm{R}^{2}$ & $\odot .017$ & $\odot .017$ & $\odot .0007$ & $\odot .019$ & 0.118 & $\odot .015$ \\
\hline Sample size & 454 & 479 & 454 & 454 & 454 & 454 \\
\hline Model & Fixed Effects & Fixed Effects & Fixed Effects & Fixed Effects & Fixed Effects & Fixed Effects \\
\hline
\end{tabular}

Note: (1) Figures in parenthesis show z-statistics.

(2) ***indicate 1 percent significance level. **indicate 5 percent significance level. *indicate 10 percent significance level. 


\subsubsection{Economic Significance}

I have shown above the statistical significance of the effects of VAT ratio and VAT share on VAT evasion index. Next, I briefly explain the economic significance of the results. Since the regression equation is used in the log linear form, the coefficients represent the elasticity of the respective variables. It means that, using results from column (1) of Tables 10a and 10b, a 1 percent increase in the VAT share or VAT ratio lowers the VAT evasion index approximately from 0.22 to 0.30 percent. The VAT ratio in Germany, for example, increased from 6.7 percent in 1995 to 6.9 percent in 1999 by 2.98 percent. Using the results from this study, it suggests that VAT evasion index was lowered approximately from 0.66 to 0.89 percent for the same period. Similarly, a one percent increase in the standard VAT rate would increase the evasion index approximately by 0.32 to 0.37 percent.

One main caveat of this study pertains to the assumption of computing VAT evasion index. I applied only the standard VAT rate assuming that the effect of reduced rate and higher rate balance each other. Depending on which rate outweighs the other, the index can be upward or downward biased, though the bias would be consistent in the same direction.

\subsection{Summary and Conclusion}

I empirically analyzed VAT evasion and how it changed over time across a sample of 25 OECD countries as reliance on VAT increased in these countries. I used two alternative measures of VAT reliance as independent variables. These measures are: VAT Ratio and 
VAT Share. My results show a negative relationship between these variables and VAT evasion. In other words, an increase in VAT reliance decreases the VAT evasion. Moreover, my results also show that an increase in the standard VAT rate increases the VAT evasion. Overall, the results are quite robust to various econometric specifications and estimation techniques.

The results of this study imply that countries could reduce the real cost of the VAT evasion by relying more on it. Moreover, this study has also an important implication for the United States too. Given that the projected budget deficit is mounting each year, clearly a VAT would be a better alternative to deal with the twin problems of budget deficit and tax evasion simultaneously. 


\section{Chapter 3}

\section{The Revenue Impact of Repeated Tax Amnesties}

\subsection{Introduction}

In fiscal year 2004, states faced budget deficits in the range of $\$ 70$ billion to $\$ 85$ billion, representing between 14.5 percent and 18 percent of all state expenditures ${ }^{14}$. Because of state balanced budget requirements, states must take actions to close deficits through spending cuts, tax increases, or dissaving. ${ }^{15}$ As Sobel (1998) shows, tax increases and expenditure reductions can be politically costly for a legislature in terms of reduced chances of reelection. With the pressure to raise additional revenue, many states have begun to offer, and in many cases repeatedly offer, periods of state tax amnesty. ${ }^{16}$ Some states like Arkansas, Mississippi, West Virginia, and Texas conducted an amnesty for a second or third time in 2004.

Tax amnesties are government programs that typically allow a short period of time for tax evaders to voluntarily repay previously evaded taxes without being subject to penalties and prosecution that discovery of such tax evasion normally brings. A typical state tax amnesty has three general characteristics. ${ }^{17}$ First, a tax amnesty is short lived in nature, generally lasting from two to three months. Second, participation in an amnesty is voluntary. Individuals may decide not to participate; however, consequences of not

\footnotetext{
${ }^{14}$ The ideas in this chapter are developed with Russell S. Sobel; I am grateful to him.

${ }^{15}$ Vermont and Wyoming are the two states which do not have balance budget requirement, however, while Vermont's statutory provisions indicate that budget balance is a goal, for practical purpose a strong expectation for a balanced budget was cited as a requirement in Wyoming (GAO 1993).

${ }^{16}$ For a good discussion of this incentive see NASBO (2004).

${ }^{17}$ For alternative definitions of tax amnesty, see U.S. Congress, Joint Committee on Taxation (1998).
} 
participating could be such that if they are caught later, they could get a stiffer punishment than before. Finally, an amnesty, as the term implies, generally waives the fines and penalties associated with the evasion but not the principal amount of taxes that is due.

Tax amnesties are a controversial issue. ${ }^{18}$ One argument put forward by Malik and Schwab (1991) in favor of tax amnesties is that some evaders would like to rejoin the tax system, but don't because of fines and possible public embarrassment they might face if they reveal their evasion. If an amnesty is offered, these people can rejoin the tax system without facing fines and this embarrassment. Cases like this are clearly a ceteris paribus Pareto improvement because these individuals gain, and revenue increases, while no one else loses. Government raises more tax revenue not only in the short run from collecting overdue taxes, but also by bringing former non-filers back into the tax system for the long run. On the other hand, some question whether tax amnesties really produce additional revenue given that they simply collect revenue that would (or could) have been raised by normal enforcement procedures anyway (recovered taxes and fines). Critics also contend that tax amnesties provide incentives for otherwise honest taxpayers to start evading taxes because they will anticipate the offering of future amnesties, thereby weakening tax compliance and fostering a perception of inefficiency in the tax system. Moreover, Alm and Beck (1993) and Malik and Schwab (1991), argue that to attribute the revenue collected during an amnesty solely to the amnesty itself is incorrect, because

\footnotetext{
${ }^{18}$ Hasseldine (1998) lists four advantages and four disadvantages of a tax amnesty. For a detailed discussion of the advantages and disadvantages of an amnesty, see Leonard and Zeckhauser (1986).
} 
increased compliance efforts are typically announced in conjunction with an amnesty (fostering increased compliance), making it difficult to separate the effects of the amnesty and the threat of increased enforcement. Table 3.1 gives a more detailed listing of the most common arguments for and against tax amnesties. ${ }^{19}$

\section{Table 3.1 - Arguments in Favor and Against Tax Amnesties}

\section{Arguments in Favor:}

1. Pareto improving because nobody looses and government increases revenue.

2. Brings people back to the path of honesty who became tax delinquents or evaders by mistake.

3. Removes the guilty feeling of otherwise ordinary citizens.

4. Most appropriate before increasing penalties and enforcement and to the transition to a new tax regime.

5. Sends a signal that the government is committed to tackle the problem of tax evasion.

6. Enlarges the tax base as many taxpayers are brought back into the tax system.

7. Generates both short run and long run revenues for the government.

8. Reduces administrative costs of tax collection.

9. Enhances tax compliance by keeping and monitoring taxpayers not previously on the tax rolls.

\section{Arguments Against:}

1. Undermines tax morale, as honest taxpayers may get upset because moral costs to behave dishonestly decrease.

2. Too soft an action to be taken against law breakers.

3. Guilty feeling is removed such that honest taxpayers may actually start evading taxes.

4. Individuals become aware of the presence of rampant non-compliance in the tax system.

5. Sends a wrong signal of a weak government, which is unable to enforce the tax code.

6. Taxpayers would anticipate future tax amnesties, which will have a negative effect on tax compliance and erodes the tax base.

7. Experiences indicate that amnesties produce little and/or overstated revenues.

8. The revenues could have been collected with the normal enforcement procedure anyway if waited a little longer

9. Simply not possible. If it were true, then the amnesty is not required in the first place.

\footnotetext{
${ }^{19}$ See also Alm (1998, pp. 4) and Torgler, Schaltegger and Schaffner (2003, pp. 376).
} 
During the 1982 to 2004 period, twenty-seven states offered a "repeated" tax amnesty (i.e., for a second or third time) to their residents. While previous research has estimated, for individual states, the impact of a specific tax amnesty on state tax revenue, none have explored how the impact of a tax amnesty changes as it is offered more than once. In this chapter I explore this issue, using a panel of quarterly tax data for all 50 states for 1980 to 2002. The results show that the effect of offering an amnesty repeatedly is to change the revenue impact of the amnesty itself. When looking at the impact of a broad-based tax amnesty on total tax revenue, a state’s first amnesty results in a short-run increase in revenue, but is accompanied by a long-run revenue loss, likely due to lower future compliance. Neither the second nor third amnesty produce significant short-run revenue, but they do create significant long-run revenue losses that grow with each amnesty, and grow with how quickly they are repeated within the state. The results suggest that broad-based tax amnesties should, at a minimum, be used only once, and even then there is a long-run revenue loss whose present value probably exceeds the short-run revenue gain from offering even the first amnesty.

\subsection{Literature Review}

Within the standard expected-utility model of tax evasion, it is a puzzle why a tax evader would participate in a tax amnesty. The model clearly predicts that amnesties would have no effect on the behavior of delinquent taxpayers. If an individual evaluates the costs and benefits of evasion, and makes the decision to evade taxes, this decision would be unaffected by the announcement of the amnesty because it doesn't change the expected 
marginal costs and expected marginal benefits of evasion. This puzzle has been addressed by Malik and Schwab (1991) who show that in an adaptive utility framework, where a taxpayer learns about his or her utility function through experience, the decision to evade could be affected by offering a tax amnesty now that their utility function has been internally updated with revised calculated risks. Furthermore, in practice, amnesties are generally offered in conjunction with an announcement of increased enforcement. The threat of (credible?) higher enforcement effort in the near future (and the higher expected cost of evasion it entails) works as an additional incentive for an evader to participate in an amnesty program.

Alm and Beck (1990, 1991) and Andreoni (1991) have theoretically analyzed the impact of tax amnesties from a different perspective. Alm and Beck $(1990,1991)$ show that amnesties may sometimes increase compliance and tax collections, especially if individuals perceive paying taxes is the social norm and the amnesty is accompanied by heightened enforcement efforts. However, amnesty revenues may come at the expense of reduced long-run tax revenues because of the reduction in tax compliance. The authors conclude that although tax amnesties generate short-term revenues, their ability to generate revenues in the long run is ambiguous. Andreoni (1991), on the other hand, examines fully anticipated tax amnesties and finds that evasion rises as a result of the amnesty but tax revenue does not necessarily fall. This is because evasion rises only to the extent that people expect to participate in the amnesty and if they participate in the amnesty, then the government is able to recapture not only the new evasion but also the 
pre-existing evasion. If the initial evasion is large, then the amnesty may increase tax revenue even if there is an increase in evasion.

Most often the success of an amnesty is measured in terms of revenue yield and attracting participants and retaining them in the tax system in subsequent years. Fisher, Godderis and Young (1989), Joulfaian (1988) and Christian, Gupta and Young (2002) have made attempts to address the latter issue. Analyzing the 1986 Michigan amnesty, Fisher, Godderis and Young (1989) find that most non-filers were out of compliance only for a single year prior to the amnesty, that only a small number of taxpayers evaded large amounts of taxes over long periods of time, and that most taxpayers used the amnesty as an opportunity to pay a relatively small amounts of overdue taxes. Similarly, using 1983 Massachusetts amnesty data, Joulfaian (1988) finds that habitual evaders, or evaders who pay taxes but underreport them, generally did not participate in the amnesty program. This conclusion is at odds with the claim that amnesties bring habitual evaders back into the system, providing substantial long-run revenue gains. In a recent study of the 1986 Michigan amnesty, in sharp contrast to previous findings, Christian, Gupta, and Young (2002) find that a substantial portion of amnesty program participants subsequently continued to file tax returns. They conclude that the 1986 Michigan amnesty was successful in attracting many participants and in retaining many of them in the system, however, its impact on revenue was negligible (about 0.1 percent of state personal income tax revenue).

In order to examine the long run effects of a tax amnesty, Alm, McKee, and Beck (1990) use laboratory experimental methods and find that compliance falls after an 
amnesty, however, they also find compliance to rise if post amnesty enforcement efforts are increased. Using cross country experiments in Switzerland and Costa Rica, Torgler and Schaltegger (2003) and Torgler, Schaltegger and Schanffner (2003) find that longrun tax compliance rises if the possible tax amnesty is subjected to a popular vote, regardless of whether the amnesty is passed or rejected. However, Torgler, Schaltegger and Schaffner (2003) also find that the anticipation of a future tax amnesty has a negative effect on tax compliance. Similarly, using state level data, Alm and Beck (1991) show that heightened post-amnesty enforcement encourages greater participation in an amnesty. The U.S. Congress's Joint Committee of Taxation (1998) interprets Connecticut's second amnesty to be consistent with these results. In another study, Alm and Beck (1993) examine the 1985 Colorado tax amnesty using monthly individual income tax revenue data from January 1980 to December 1989 and conclude that the amnesty had no long run impact on the level or the trend of tax collections. Table 3.2 summarizes the tax amnesty literature. 
Table 3.2 - Summary of Literature Review

\begin{tabular}{|c|c|c|c|c|}
\hline Authors & Type of Study & Amnesty & Data & Main Results \\
\hline $\begin{array}{l}\text { Malik and Schwab } \\
\text { (1991) }\end{array}$ & Theoretical study & - & - & $\begin{array}{l}\text { Taxpayers learn their utility function through experience. People participate in an amnesty } \\
\text { after they internally update the costs and benefits of evasion and realize that costs are actually } \\
\text { higher than the benefits. }\end{array}$ \\
\hline Alm and Beck (1990) & Theoretical study & - & - & $\begin{array}{l}\text { Amnesties may sometimes increase compliance and tax collections, if individuals perceive } \\
\text { paying taxes is the social norms. }\end{array}$ \\
\hline Alm and Beck (1991) & $\begin{array}{l}\text { Empirical cross } \\
\text { sectional study }\end{array}$ & $\begin{array}{l}28 \text { US } \\
\text { States }\end{array}$ & 1980-1988 & Heightened post-amnesty enforcement encourages greater participation in an amnesty. \\
\hline Alm and Beck (1993) & $\begin{array}{l}\text { Empirical time } \\
\text { series analysis }\end{array}$ & $\begin{array}{l}\text { Colorado } \\
1985\end{array}$ & 1980-1989 & No long run effects on the level or the trend of tax collections. \\
\hline $\begin{array}{l}\text { Dubin, Graetz and } \\
\text { Wilde (1992) }\end{array}$ & Empirical study & US States & 1980-1988 & If the IRS is active in a state, then the state is less likely to offer a tax amnesty. \\
\hline $\begin{array}{l}\text { Christian, Gupta and } \\
\text { Young (2002) }\end{array}$ & Empirical study & Michigan & 1983 & $\begin{array}{l}\text { Two-thirds of new filers and nine-tenths of previous filers who filed amended returns under } \\
\text { amnesty filed a state income tax return subsequently. Amnesty impact ( } 5,500 \text { new taxpayers) } \\
\text { on revenues, inducing } 0.1 \text { percent of Michigan’s personal income tax, is negligible. }\end{array}$ \\
\hline $\begin{array}{l}\text { Alm, McKee and Beck } \\
\text { (1990) }\end{array}$ & $\begin{array}{l}\text { Experimental } \\
\text { study }\end{array}$ & & & $\begin{array}{l}\text { Average level of tax compliance falls after a tax amnesty. Expectations of an amnesty reduce } \\
\text { compliance. Revenues from an amnesty are greater if post-amnesty enforcement increases. }\end{array}$ \\
\hline Posner (2000) & Empirical & US States & 1983-1997 & The likelihood of a tax amnesty increases if the government in that state is unstable. \\
\hline $\begin{array}{l}\text { Torgler, Schaltegger } \\
\text { and Schaffner (2003) }\end{array}$ & $\begin{array}{l}\text { Experimental } \\
\text { study }\end{array}$ & - & - & $\begin{array}{l}\text { Long-run tax compliance rises if tax amnesty is subjected to a popular vote, regardless of } \\
\text { whether the amnesty is passed or rejected. }\end{array}$ \\
\hline $\begin{array}{l}\text { Torgler, Schaltegger } \\
\text { (2003) }\end{array}$ & $\begin{array}{l}\text { Experimental } \\
\text { study }\end{array}$ & - & - & Anticipation of a future tax amnesty has a negative effect on tax compliance. \\
\hline
\end{tabular}




\subsection{A Review of International Tax Amnesty Experience}

Many developed as well as developing countries have conducted tax amnesties as part of their fiscal program. Just like the U.S. states, some of these countries have made repeated use of amnesties. For example, Argentina, France, India, Ireland and Italy have offered tax amnesties for a number of times and sometimes the repetition of amnesty took place at an interval as short as every two years. Table 3.3 provides summary information of modern tax amnesty around the world.

The terms and conditions of tax amnesties vary from country to country. Many countries have had tax amnesties, both general amnesties and amnesties covering only specific taxes. Some amnesties have not only abated penalties but also interest and even liabilities for tax. For example, the 1996 Venezuela tax amnesty reduced tax liabilities of participating taxpayers by 75 percent and, the 1974 Panama tax amnesty reduced tax liabilities by 80 percent. Many amnesties have allowed taxpayers with accounts receivable or in civil tax litigation to participate. For example, the 1995 Argentina tax amnesty allowed even taxpayers involved in criminal tax proceedings to participate in the amnesty. Likewise, amnesty collection across countries varies quite a lot. For example, the 1995 general amnesty in Argentina yielded about \$3.9 billion, the 1993 general amnesty in India yielded about $\$ 2.5$ billion and the Irish amnesty of 1988 yielded more than $\$ 700$ million. ${ }^{20}$ Tax amnesty experience of selected countries is briefly discussed below.

\footnotetext{
${ }^{20}$ See United States Congress, Joint Committed on Taxation (1998) and Alm (1998).
} 
Table 3.3 - International Comparison of Tax Amnesties

\begin{tabular}{|c|c|c|}
\hline Country & Amnesty Year & Form/Main Taxes Covered \\
\hline Argentina & 1987 & Previously unreported income for investment purpose \\
\hline Argentina & 1995 & General tax amnesty \\
\hline Australia & Twice during $80 \mathrm{~s}$ & $\begin{array}{l}\text { Participants in specific avoidance scheme, persons not } \\
\text { lodging returns }\end{array}$ \\
\hline Austria & 1982 & All tax claims prior to 1979 \\
\hline Austria & 1993 & Special program to encourage repatriation of untaxed assets \\
\hline Belgium & $1984 / 1985$ & $\begin{array}{l}\text { Income exempted from tax if invested (e.g. government } \\
\text { bonds) }\end{array}$ \\
\hline Colombia & 1987 & $\begin{array}{l}\text { Report previously unreported assets or over-reported } \\
\text { liabilities }\end{array}$ \\
\hline Finland & $1982 / 1984$ & Surplus Interest Affairs \\
\hline France & 1982 & $\begin{array}{l}\text { General tax amnesty } \\
\text { Special program to encourage repatriation of untaxed assets }\end{array}$ \\
\hline France & 1986 & Second special amnesty for assets held abroad \\
\hline India & 1981 & Government bonds designed for untaxed income \\
\hline India & 1997 & General tax amnesty \\
\hline Ireland & 1988 & General tax amnesty \\
\hline Ireland & 1993 & General tax amnesty \\
\hline Italy & 1982 & General tax amnesty \\
\hline Italy & 1984 & Entrepreneurs and self employed \\
\hline Italy & $2001 / 2002$ & Special program to encourage repatriation of untaxed assets \\
\hline Netherlands & $\begin{array}{l}1934,1940 \\
1945,1955\end{array}$ & 1955, exemption from penalties and interest \\
\hline New Zealand & 1988 & General tax amnesty \\
\hline Portugal & $\begin{array}{l}1981,1982, \\
1986,1988\end{array}$ & Limited to income taxation \\
\hline Russia & 1993 & $\begin{array}{l}\text { Enterprises, organizations, private entrepreneurs not liable } \\
\text { for any sanctions on unpaid liabilities. }\end{array}$ \\
\hline Russia & 1996, 1997 & $\begin{array}{l}\text { Enterprises and organizations were allowed to defer } \\
\text { payments on the arrears }\end{array}$ \\
\hline Spain & 1977 & Exemption from penalty for liabilities settled prior to 1976. \\
\hline
\end{tabular}

Source: Torgler and Schaltegger (2003) pp. 6. 


\subsubsection{Argentina}

In 1987, with an objective to encourage repatriation of capital flight, Argentina ran a tax amnesty for its citizens and foreign nationals. As part of its debt-to-equity program, the amnesty exempted from taxes all previously unreported income used for investment purposes. Moreover, the amnesty also promised not to investigate the origin of the funds or prosecute the delinquent taxpayers. The only condition set for the amnesty was that for every dollar of debt converted into equity, the investor was required to make a matching contribution of an additional dollar in new funds, and the funds so raised were to be used either to purchase new equipment or build new plants or improve the physical capacity of existing facilities. Because Argentina had offered several tax amnesties in the past, and the 1987 amnesty was not accompanied by any stricter enforcement efforts, or changes in the tax code, it virtually brought no revenues to the government and thus it was widely viewed as failure. (Uchitelle 1989, Alm 1998)

\subsubsection{Belgium}

With an objective to attract flight capital and black market funds to bring back into the regular economy, Belgium enacted a tax amnesty in 1984. The amnesty exempted such capital from taxes if the capital was invested in employment-generating activities before the end of 1984. The amnesty also waived from any obligation to report the origin of the funds, provided that one-eleventh, or 9 percent, of the amount in question had to be invested in five-year non-interest-bearing treasury certificates. However, the then 
government faced a number of political problems in 1985, and was compelled to rescind the amnesty legislation. (Uchitelle 1989)

\subsubsection{Columbia}

Colombia ran a tax amnesty in 1987. The tax amnesty allowed taxpayers who had previously failed to report or who over reported their liabilities to correct their reports without subject to investigation. Known delinquents were excluded from participating in the amnesty. To be eligible in the amnesty, the taxpayers had to declare their income at least as high as their reported income in the previous years. The amnesty was accompanied by many changes in the tax system. The government reduced the income tax rates, increased income tax withholding rates and eliminated the double taxation of dividends. Enforcement of the tax code and penalties detected for post amnesty tax evasion were also increased. The amnesty collected about $\$ 94$ million, or about 0.3 percent of GDP in 1987. (Uchitelle 1989, Alm 1998)

\subsubsection{Costa Rica}

Considering a tax reform incorporating a tax amnesty, the congress of Costa Rica approved the tax contingency law in December 2000, and the President sanctioned the bill on December 18 and became effective on January $1^{\text {st }} 2003$. The reform consisted, among others, of an increase in the income tax rate, corporate tax rate, property tax rate. The tax amnesty allowed tax payers two months period to clear up tax liabilities for taxes managed by the tax authorities which included income tax, sales tax, selective 
consumption tax, property tax on vehicles, transfer tax of real property and vehicles, education and culture stamp tax, tax on offshore companies, taxes on gambling houses, specific tax on alcoholic beverage etc. Costa Rica had previously offered a tax amnesty in 1995. (Torgler, Schaltegger and Schaffner 2003)

\subsubsection{France}

France has made repeated use of tax amnesty as a fiscal policy tool. ${ }^{21}$ With an objective to stimulate repatriation of illegally held capital abroad, France ran a general amnesty as well as a special program in 1982. The general amnesty applied to all income and value added taxes. A total of 2,786 people participated in the general amnesty who paid about \$19 million. Similarly, a total of 276 people participated in the special program to repatriate capital who brought back about \$22 million. However, these programs were not considered as successful partly due to the high wealth tax prevailing in France at that time.

In 1986, France repeated a tax amnesty for a second time. Like previous amnesty, the objective of the 1986 amnesty was to recoup income illegally transferred abroad. The tax rate was significantly reduced from 25 percent in 1982 to 10 percent in 1986 on repatriated capital. Moreover, the wealth tax was also abolished. These additional measures were taken to address the causes of the failure of 1982 amnesty. However, enforcement was not increased after the amnesty. The exact amnesty collection was not known but was believed to be small.

\footnotetext{
${ }^{21}$ See also Alm (1998; pp. 6), Hasseldine (1998; pp. 305-306), JCT (1998; pp. 32) and Uchitelle (1989; pp. 52-53).
} 


\subsubsection{India}

India is one of the countries which have frequently used tax amnesties as a fiscal policy tool. Of the many amnesties, the two important and widely cited ones conducted in 1981 and 1997 are briefly discussed here. ${ }^{22}$

In February 1981, India ran a tax amnesty for about a period of three months. The amnesty was considered unique in that the government issued special bearer bonds with an objective to tap untaxed income. People holding undisclosed incomes were allowed to purchase the bonds and were promised not to investigate the origin of the funds. The money invested in the bonds was exempted from all types of taxes. The amnesty was able to collect over one billion dollars from the issuance of such bonds. After the conclusion of the amnesty, the tax structure didn't change and enforcement was not increased. As such the amnesty was not considered successful for it didn't raise as much revenue as anticipated nor did it widen the overall tax base.

From July through December in 1997, India ran another amnesty for a total of 214 days with a slogan "30 percent taxes, 100 percent peace of mind". The amnesty presented a large element of forgiveness to tax evaders. Unlike previous amnesties, this amnesty was extensively publicized by different forms of media, e.g. radio, television, newspaper etc. with the emphasis that the amnesty would be the last of its kind and enforcement was increased after the conclusion of the amnesty. A total of 350,000 people participated in the amnesty and $\$ 2.5$ billion was collected of which approximately one

\footnotetext{
${ }^{22}$ See also Alm (1998; pp. 5-6), Torgler and Schaltegger (2003; pp. 4-5) and Uchitelle (1989; pp. 51).
} 
half was from individual income tax alone. This is considered one of the successful amnesties.

\subsubsection{Ireland}

Ireland is another country which has made repeated use of tax amnesties - five amnesties in six years between two general amnesties in 1988 and $1993 .{ }^{23}$ The first general tax amnesty of Ireland was run from January through October in 1988. The amnesty allowed taxpayers a period of ten months to pay taxes without incurring any interests or penalties or civil or criminal lawsuits. The amnesty was publicized as one time opportunity only and at the conclusion of the amnesty, the enforcement of the tax code was increased. Moreover, the overall tax structure was also reformed. Tax authorities anticipated to raise $\$ 50$ million dollars but the revenue collection actually exceeded over $\$ 700$ million dollars. The amnesty was considered to be successful. The following reasons were attributed to its success: (i) It was the first amnesty in Ireland. (ii) The amnesty was well publicized as the last opportunity for delinquent tax payers to be forgiven. (iii) Postamnesty enforcement of tax code was increased and the tax structure was reformed. (iv) Penalty for the detected post-amnesty tax evasion was increased. (v) Finally, during the amnesty the government actually started publishing in the national newspapers lists of the names of people who were delinquent in their tax payments.

Although the 1988 amnesty was publicized as the only first and last opportunity, because Ireland faced with a serious budget deficit, it announced in 1993 a special

${ }^{23}$ See also Alm (1998; pp. 6), Hasseldine (1998; pp. 306), JCT (1998; pp. 32-33) and Uchitelle (1989; pp. $51)$. 
amnesty with the objective to stimulate repatriation of undeclared income from abroad. The special amnesty waived all penalties and interest and promised of confidentiality of the source of the fund. The repatriated funds were subject to a special low rate of 15 percent, in contrast to normal rate, which was above 50 percent. However, the parliamentary opposition parties and trade unions criticized the amnesty as a concession to the wealthy few taxpayers. The government, then, responded by adopting a general amnesty which offered abatement of both penalties and interest but liabilities were not reduced. The 1993 amnesty was not considered successful for the revenue collection was reported to be significantly lower than for the 1988 general amnesty.

\subsubsection{Italy}

Italy is another country which has most frequently used tax amnesties in contemporary period. It offered four general amnesties and numerous specific tax amnesties usually by decree since 1973. The four general amnesties were held in 1973, 1982, 1991 and 2003. They were very much similar in their nature and characteristics. All of these amnesties provided full tax relief of previously undeclared taxes. Taxpayers without any new declarations of tax base but only by paying a fixed percentage of the gross tax already paid could benefit the total exemptions from future inspection. Collections in Italian amnesties have not been encouraging. For its general amnesty in 1982, the Italian government expected to raise $\$ 4.6$ billion in revenues but actual collections were far less than anticipated, only approximately $\$ 700,000$. Tax amnesties have occurred so regularly 
in Italy that the expectation of future amnesties has been cited as a factor in the low national level of tax compliance. (JCT 1998, Marè and Salleo 2003)

\subsubsection{New Zealand}

New Zealand ran a tax amnesty in 1988. Unlike amnesties in other countries where penalties for tax offences are generally increased only after the amnesty period is over, New Zealand considerably strengthened penalties for tax offences two years prior to the amnesty. Late payment penalty was still charged even if amnesty was granted to the taxpayers. Late penalty was considered as charge against the use of the time value of money, otherwise amnesty participants would have been effectively paying lower taxes than taxpayers who paid their taxes on time. The amnesty promised taxpayers would not be subject to investigation just because they participated in the amnesty. Nonetheless, a full disclosure from each amnesty participating taxpayer was required. Approximately 16,000 participants filed a total of 24,685 amnesty returns which resulted in total tax assessed of USD 26.6 million and USD 3 million in refund, with most returns relating to income tax. (Hasseldine 1998)

\subsubsection{Russia}

During the entire transition period, Russia experienced tax problems such as lagging in tax collections as well as wide spread tax evasion. ${ }^{24}$ Therefore, with an objective of reforming the tax system, Russia has enacted tax amnesties a number of times since 1992.

\footnotetext{
${ }^{24}$ See Alm, Martinex-Vazquez and Wallace (2000).
} 
Russia ran its first amnesty from October 27 to November30 in 1993 by presidential decree. The amnesty waived any penalties on the unpaid liabilities if participating enterprises, organizations and private entrepreneurs disclosed their unpaid taxes and tax payments for 1993 and all preceding years. After the amnesty, the penalty for the detected tax evasion was increased by three times of the unpaid tax liability. However, the amnesty was not successful because the design of the amnesty was considered flawed and it was criticized for having the time-frame of one month to repay tax liabilities too short and not allowing for inadvertent or unintended mistakes. As such, the 1993 amnesty was repealed in 1995.

Russia ran a second amnesty again by presidential decree in on January 16, 1996, which was later amended on April 22, 1996. The second amnesty allowed enterprises and organizations with tax arrears to defer their payments, provided that they timely paid all current payments in full. Enterprises and organizations that were granted deferments were required to pay 50 percent of the total amount due by October 1998, with the quarterly payments of 5 percent of the liabilities. A 30 percent annual interest rate was charged on the unpaid amounts. The remaining 50 percent deferment liability could be paid over the following five years in equal payments without any interest charge. However, the requirement of 50 percent of the arrears to be paid by October 1998, with the remaining 50 percent subject to an annual interest rate of 30 percent was impractical. Nonetheless, the amnesty was continued in somewhat modified form by additional presidential decrees, which also contained provisions such as reduced interest penalties on late payments and on tax arrears and an allowance for unintended mistakes in the preparation 
of tax returns, all of which were intended to reduce the burden of tax payment. Moreover, also the tax authorities were expected to increase the frequency of tax audits.

In summary, the Russian tax amnesties were not very successful. Given the poor quality of tax administration in Russia, these amnesties and related provisions were seen by tax officials as easy ways of dealing with delinquent tax liabilities, especially those of mounting tax arrears. Furthermore, the almost yearly enactment of some form of amnesty contributed to the widespread belief that they would be a regular event.

\subsubsection{Switzerland}

After the Second World War, Switzerland ran three general tax amnesties at national level. ${ }^{25}$ In 1940, trying to find new ways to finance the defense costs that incurred during the World War II, the Swiss government levied an extraordinary property tax as a onetime charge. Although new federal taxes needed to pass by a popular referendum, the cabinet used its extended legal power at war time and enacted the new tax by decree. The revenue collection from such type of amnesty was not successful, however.

Switzerland ran its second general amnesty in 1944. The amnesty was accompanied by a stricter enforcement of tax code and exchange of information between national and sub-national tax authorities. This amnesty was considered to be quite successful.

In the early 1960s, tax amnesty at the federal level surfaced again. Although the federal government didn't like the idea of the amnesty without increasing the

\footnotetext{
${ }^{25}$ See Torgler and Schaltegger (2003) and Torgler, Schaltegger and Schaffner (2003).
} 
enforcement, the parliament proposed a bill for tax amnesty, which was defeated in the 1964 popular referendum. Subsequently, the proposal was modified and re-forwarded for referendum which was then approved by a majority of the votes. 


\subsection{US State Tax Amnesty Experience}

Combined, the fifty U.S. states offered a total of 76 tax amnesties during the past 23 years. Figure 3.1 illustrates how frequently some states have offered tax amnesties as of December 2004. Only 10 states have never offered a tax amnesty. Thirteen states have offered a tax amnesty only once. The remaining 27 states have offered tax amnesties on multiple occasions, 8 of them offering three or more amnesties. Of the 76 amnesties offered during the sample period, 72 included all major state taxes, and 4 were for a specific tax only (e.g. income tax, sales tax and use taxes, etc.). Some of these broadbased amnesties, however, do exclude some taxes (most often property and motor fuel taxes). ${ }^{26}$ Of the four specific amnesties, the focus of the California (1985) and Oklahoma (1984) amnesties was on individual income and sales taxes, whereas the focus of the Arizona (2002) and Idaho (1983) amnesties was individual income taxes.

The popularity of states offering tax amnesties begins in the early 1980s. ${ }^{27}$ Table 3.4 shows the number of states offering tax amnesties for each year between 1982 and 2004, and the distribution by whether it was the state's first, second, third, or fourth amnesty. The frequency of tax amnesties rose during the late 1990s, and especially during and after the most recent recession (21 amnesties were offered in 2002 and 2003 combined). The phenomenon of states offering a second, or subsequent, amnesty

\footnotetext{
${ }^{26}$ For a detailed listing see: FTA, http://www.taxadmin.org/fta/rate/amnesty1.html

${ }^{27}$ Although Dubin, Graetz, and Wilde (1992) find the main determinant of whether a state offers a tax amnesty to be the level of IRS auditing within the state (that is, if the IRS is active in a state, then that state is less likely to offer a tax amnesty) and Posner (2000) finds that the likelihood of an amnesty in a given year in a state increases if the government in that state is unstable, a distinct geographic pattern can be seen in our data.
} 
becomes common only after mid-1990s. As of December 2004, 40 states have offered at least one amnesty and 27 states have offered repeated amnesties. For the 23 years listed in Table 3.4, at least one state offered an amnesty in all but four of the years.

Figure 3.1 - Tax Amnesty Offerings by State (as of December 2004)

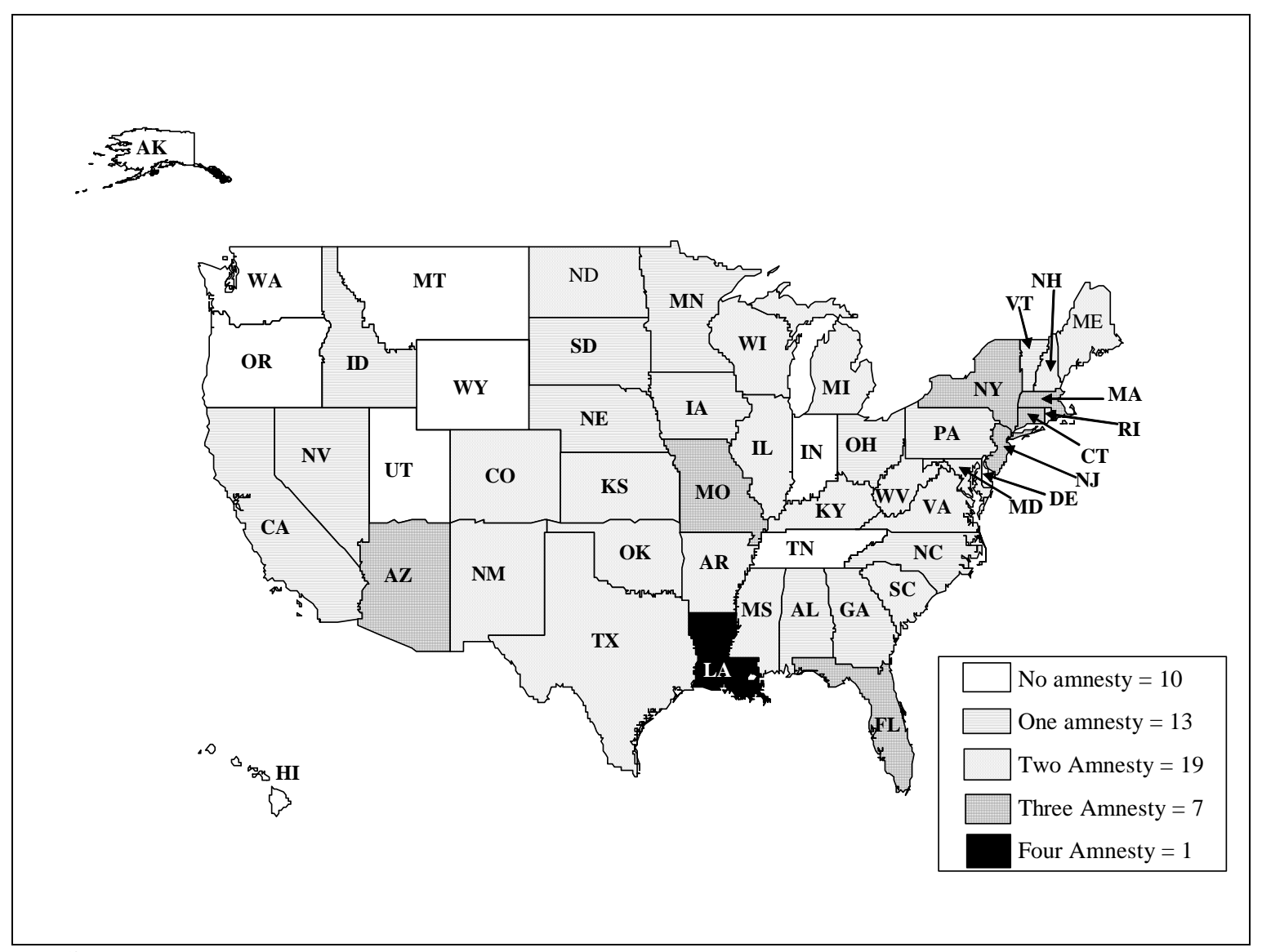

Source: FTA, January 2005. http://www.taxadmin.org/fta/rate/amnesty1.html 
Table 3.4 - Number of States Offering Tax Amnesties by Year

\begin{tabular}{|c|c|c|c|c|c|}
\hline Year & $\begin{array}{c}\text { Total } \\
\text { number } \\
\text { offering } \\
\text { amnesties }\end{array}$ & $\begin{array}{c}\text { Number } \\
\text { offering } \\
\text { first } \\
\text { amnesty }\end{array}$ & $\begin{array}{l}\text { Number } \\
\text { offering } \\
\text { second } \\
\text { amnesty }\end{array}$ & $\begin{array}{l}\text { Number } \\
\text { offering } \\
\text { third } \\
\text { amnesty }\end{array}$ & $\begin{array}{c}\begin{array}{c}\text { Number } \\
\text { offering } \\
\text { fourth }\end{array} \\
\text { amnesty }\end{array}$ \\
\hline 1982 & 1 & 1 & - & - & - \\
\hline 1983 & 4 & 4 & - & - & - \\
\hline 1984 & 7 & 7 & - & - & - \\
\hline 1985 & 6 & 6 & - & - & - \\
\hline 1986 & 5 & 5 & - & - & - \\
\hline 1987 & 5 & 4 & 1 & - & - \\
\hline 1988 & 2 & 1 & 1 & - & - \\
\hline 1989 & 1 & 1 & - & - & - \\
\hline 1990 & 4 & 4 & - & - & - \\
\hline 1991 & - & - & - & - & - \\
\hline 1992 & 1 & 1 & - & - & - \\
\hline 1993 & - & - & - & - & - \\
\hline 1994 & - & - & - & - & - \\
\hline 1995 & 2 & 1 & 1 & - & - \\
\hline 1996 & 3 & - & 3 & - & - \\
\hline 1997 & 1 & 1 & - & - & - \\
\hline 1998 & 2 & - & 1 & 1 & - \\
\hline 1999 & 2 & 1 & 1 & - & - \\
\hline 2000 & - & - & - & - & - \\
\hline 2001 & 4 & 1 & 2 & - & 1 \\
\hline 2002 & 11 & 1 & 7 & 3 & - \\
\hline 2003 & 10 & - & 6 & 4 & - \\
\hline 2004 & 5 & 1 & 4 & - & - \\
\hline Total & 76 & 40 & 27 & 8 & 1 \\
\hline
\end{tabular}


Table 3.5 shows that a majority of states sought approval for their amnesty through legislative authorization. Forty-two state amnesties allowed accounts receivable to participate in the tax amnesty. Twenty six states allowed taxes to be paid in installments whereas thirty-one states didn’t provide any such arrangements.

Table 3.5 - Characteristics of State Tax Amnesties (1982 - 2004)

\begin{tabular}{|c|c|c|c|}
\hline & $\begin{array}{c}\text { Number of } \\
\text { Amnesties with } \\
\text { Legislative } \\
\text { Authorization }\end{array}$ & $\begin{array}{c}\text { Number of } \\
\text { Amnesties that } \\
\text { Included Accounts } \\
\text { Receivable }^{\mathrm{a}}\end{array}$ & $\begin{array}{c}\text { Number of Amnesties that } \\
\text { Permitted Installment } \\
\text { Arrangements }\end{array}$ \\
\hline Yes & 68 & 42 & 26 \\
\hline No & 7 & 25 & 31 \\
\hline No information ${ }^{b}$ & 4 & 10 & 19 \\
\hline
\end{tabular}

Source: FTA, January 2005. http://www.taxadmin.org/fta/rate/amnesty1.html. Web access date: 05/08/05. Notes: ${ }^{a}$ California's tax amnesty in 1984-85 allowed known delinquents of individual income taxes to participate in the amnesty but it didn't allow known delinquents of sales taxes to participate in the amnesty.

${ }^{\mathrm{b}}$ Information on amnesty characteristics was not available from the FTA.

Table 3.6 shows that the duration of tax amnesties varies widely across states. Although Illinois conducted a short two-week amnesty from December 28, 1981 to January 8, 1982, and Pennsylvania from March 1, 1983 to June 30, 1983, these programs did not correspond to the types of state amnesty programs that began in $1982{ }^{28}$ These amnesties, therefore, have not been included in the analysis. During the 1982 - 2004 period, the shortest amnesty was conducted by Kentucky (lasting 15 days in 1988), followed by Texas (20 days in 2004 and 29 days in 1984). The longest amnesty periods were offered by Oklahoma (183 days in 1984), Arkansas (183 days in 2004), and Florida

\footnotetext{
${ }^{28}$ For Illinois, see FTA (1990) pp.2, n.2 and for Pennsylvania, see Alm and Beck (1991) pp. 1047.
} 
(181 days in 1988 and 180 days in 1987). Of the 76 amnesties during 1982 to 2004, four amnesties lasted one month or less, 26 amnesties lasted for more than one month but less than two months, 36 amnesties lasted more than two months but less than three months, 5 amnesties lasted more than three months but less than four months, and 5 amnesties lasted more than four months.

Table 3.6 also shows data on the revenue (in constant 2000 dollars) collected during each amnesty period. This data, however, is the official data reported by each state. As discussed earlier, these reported amounts are of little value for research purposes. The data do not control for any offsetting losses, nor for the economic conditions present at the time, they are simply not close enough to satisfying the ceteris paribus conditions. Thus, while I present these amounts, the readers should also be cautioned here of the fact that a controlled econometric model used in this chapter later is the only way to really assess the true revenue impact of a tax amnesty.

Fourteen state tax amnesties were reported to bring in short-run revenues greater than or equal to $\$ 100$ million since 1982. Among those, the three largest revenue yields were in New York (2002-2003, \$582.7 million), Illinois (2003, \$532 million) and in New York (1985-86, \$401 million). On the other hand, ten state tax amnesties generated \$1 million or less, with the three smallest revenue yields being North Dakota (1983, \$0.2 million), Idaho (1983, \$0.3 million) and Louisiana (1987, \$0.3 million). While, such sharp difference in revenue yields is partially due to population and economic size of these states, there seems to be a large variation in short-term revenue yields across states. 
Table 3.6 - State Tax Amnesty Periods and Ranking of Amnesty Collections (1982 - 2004)

\begin{tabular}{|c|c|c|c|c|c|c|c|c|c|}
\hline Name of State & \multicolumn{3}{|c|}{ Amnesty Period } & $\begin{array}{c}\text { Amnesty } \\
\text { Collection } \\
2000 \$^{\mathrm{a}} \\
(000) \\
\end{array}$ & Rank & $\begin{array}{c}\text { Amnesty } \\
\text { Collection } \\
\text { Per } \\
\text { Capita } \\
\end{array}$ & Rank & $\begin{array}{c}\text { Amnesty } \\
\text { Collection per } \\
100,000 \text { State } \\
\text { Income } \\
\end{array}$ & Rank \\
\hline ALABAMA & $1 / 20 / 1984$ & 4/1/1984 & 72 & $\$ 4,730$ & 55 & $\$ 1.20$ & 55 & $\$ 7.50$ & 54 \\
\hline \multicolumn{10}{|l|}{ ARIZONA } \\
\hline First amnesty & 11/22/1982 & $1 / 20 / 1983$ & 59 & $\$ 9,201$ & 50 & $\$ 3.10$ & 49 & $\$ 17.31$ & 45 \\
\hline Second amnesty & $1 / 1 / 2002$ & $2 / 28 / 2002$ & 58 & N/A & & & & & \\
\hline Third amnesty & 9/1/2003 & $10 / 31 / 2003$ & 60 & $\$ 68,869$ & 20 & $\$ 12.34$ & 27 & $\$ 48.57$ & 23 \\
\hline \multicolumn{10}{|l|}{ ARKANSAS } \\
\hline First amnesty & 9/1/1987 & 11/30/1987 & 90 & $\$ 2,323$ & 56 & $\$ 0.99$ & 56 & $\$ 6.01$ & 56 \\
\hline Second amnesty & $7 / 1 / 2004$ & $12 / 31 / 2004$ & 183 & N/A & & & & & \\
\hline CALIFORNIA & 12/10/1984 & 3/15/1985 & 95 & $\$ 282,582$ & 5 & $\$ 10.69$ & 29 & $\$ 43.94$ & 27 \\
\hline \multicolumn{10}{|l|}{ COLORADO } \\
\hline First amnesty & 9/16/1985 & 11/15/1985 & 60 & $\$ 9,180$ & 51 & $\$ 2.86$ & 52 & $\$ 12.92$ & 48 \\
\hline Second amnesty & 6/1/2003 & 6/30/2003 & 29 & $\$ 17,359$ & 43 & $\$ 3.82$ & 46 & $\$ 11.72$ & 50 \\
\hline \multicolumn{10}{|l|}{ CONNECTICUT } \\
\hline First amnesty & 9/1/1990 & 11/30/1990 & 90 & $\$ 66,184$ & 21 & $\$ 20.12$ & 16 & $\$ 61.89$ & 21 \\
\hline Second amnesty & 9/1/1995 & 11/30/1995 & 90 & $\$ 50,159$ & 25 & $\$ 15.36$ & 21 & $\$ 44.77$ & 26 \\
\hline Third amnesty & 9/1/2002 & $12 / 2 / 2002$ & 92 & $\$ 104,716$ & 14 & $\$ 30.27$ & 8 & $\$ 73.72$ & 18 \\
\hline \multicolumn{10}{|l|}{ FLORIDA } \\
\hline First amnesty & 1/1/1987 & 6/30/1987 & 180 & $\$ 17,761$ & 42 & $\$ 1.48$ & 54 & $\$ 6.67$ & 55 \\
\hline Second amnesty & 1/1/1988 & 6/30/1988 & 181 & $\$ 11,097$ & 48 & $\$ 0.90$ & 58 & $\$ 3.93$ & 58 \\
\hline Third amnesty & 7/1/2003 & $10 / 31 / 2003$ & 122 & $\$ 75,473$ & 18 & $\$ 4.44$ & 43 & $\$ 15.68$ & 46 \\
\hline GEORGIA & 10/1/1992 & 12/5/1992 & 65 & $\$ 59,386$ & 23 & $\$ 8.79$ & 33 & $\$ 39.45$ & 31 \\
\hline IDAHO & $5 / 20 / 1983$ & 8/30/1983 & 102 & $\$ 460$ & 66 & $\$ 0.47$ & 61 & $\$ 2.96$ & 60 \\
\hline \multicolumn{10}{|l|}{ ILLINOIS } \\
\hline First amnesty & 10/1/1984 & 11/30/1984 & 60 & $\$ 237,232$ & 9 & $\$ 20.79$ & 15 & $\$ 94.56$ & 11 \\
\hline Second amnesty & $10 / 1 / 2003$ & $11 / 17 / 2003$ & 47 & $\$ 501,895$ & 3 & $\$ 39.68$ & 2 & $\$ 126.62$ & 5 \\
\hline IOWA & 9/2/1986 & 10/31/1986 & 59 & $\$ 49,263$ & 26 & $\$ 17.64$ & 18 & $\$ 89.11$ & 13 \\
\hline \multicolumn{10}{|l|}{ KANSAS } \\
\hline First amnesty & 7/1/1984 & 9/30/1984 & 91 & $\$ 887$ & 63 & $\$ 0.37$ & 64 & $\$ 1.80$ & 64 \\
\hline Second amnesty & $10 / 1 / 2003$ & 11/30/2003 & 60 & $\$ 50,661$ & 24 & $\$ 18.59$ & 17 & $\$ 66.74$ & 19 \\
\hline
\end{tabular}


Table 3.6 Cont'd

\begin{tabular}{|c|c|c|c|c|c|c|c|c|c|}
\hline \multirow[b]{2}{*}{ Name of State } & \multicolumn{3}{|c|}{ Amnesty Period } & \multirow{2}{*}{$\begin{array}{c}\text { Amnesty } \\
\text { Collection } \\
2000 \$^{\mathrm{a}} \\
(000) \\
\end{array}$} & \multirow[b]{2}{*}{ Rank } & \multirow{2}{*}{$\begin{array}{l}\text { Amnesty } \\
\text { Collection } \\
\text { Per Capita }\end{array}$} & \multirow[b]{2}{*}{ Rank } & \multirow{2}{*}{$\begin{array}{c}\text { Amnesty } \\
\text { Collection per } \\
100,000 \text { State } \\
\text { Income } \\
\end{array}$} & \multirow[b]{2}{*}{ Rank } \\
\hline & Begin & End & Days & & & & & & \\
\hline \multicolumn{10}{|l|}{ KENTUCKY } \\
\hline First amnesty & 9/15/1988 & 9/30/1988 & 15 & $\$ 132,111$ & 12 & $\$ 35.90$ & 4 & $\$ 200.34$ & 1 \\
\hline Second amnesty & 8/1/2002 & 9/30/2002 & 60 & $\$ 96,069$ & 15 & $\$ 23.49$ & 13 & $\$ 96.10$ & 10 \\
\hline \multicolumn{10}{|l|}{ LOUISIANA } \\
\hline First amnesty & 10/1/1985 & 12/31/1985 & 91 & $\$ 1,721$ & 57 & $\$ 0.39$ & 63 & $\$ 2.25$ & 63 \\
\hline Second amnesty & 10/1/1987 & $12 / 15 / 1987$ & 75 & $\$ 410$ & 67 & $\$ 0.09$ & 67 & $\$ 0.57$ & 67 \\
\hline Third amnesty & 10/1/1998 & $12 / 31 / 1998$ & 91 & $\$ 1,348$ & 60 & $\$ 0.31$ & 65 & $\$ 1.34$ & 66 \\
\hline Fourth amnesty & 9/1/2001 & $10 / 30 / 2001$ & 59 & $\$ 169,044$ & 10 & $\$ 37.85$ & 3 & $\$ 156.78$ & 2 \\
\hline \multicolumn{10}{|l|}{ MAINE } \\
\hline First amnesty & 11/1/1990 & $12 / 31 / 1990$ & 60 & $\$ 35,544$ & 34 & $\$ 28.87$ & 9 & $\$ 135.50$ & 4 \\
\hline Second amnesty & $9 / 1 / 2003$ & $11 / 30 / 2003$ & 90 & $\$ 35,472$ & 35 & $\$ 27.09$ & 11 & $\$ 99.52$ & 9 \\
\hline \multicolumn{10}{|l|}{ MARYLAND } \\
\hline First amnesty & 9/1/1987 & $11 / 2 / 1987$ & 62 & $\$ 47,270$ & 28 & $\$ 10.35$ & 30 & $\$ 39.45$ & 30 \\
\hline Second amnesty & $9 / 1 / 2001$ & $10 / 31 / 2001$ & 60 & $\$ 38,282$ & 33 & $\$ 7.12$ & 39 & $\$ 20.50$ & 42 \\
\hline \multicolumn{10}{|l|}{ MASSACHUSETTS } \\
\hline First amnesty & 10/17/1983 & 1/17/1984 & 92 & $\$ 127,854$ & 13 & $\$ 21.89$ & 14 & $\$ 94.19$ & 12 \\
\hline Second amnesty & 10/1/2002 & $11 / 30 / 2002$ & 60 & $\$ 92,323$ & 17 & $\$ 14.40$ & 23 & $\$ 38.46$ & 32 \\
\hline Third amnesty & $1 / 1 / 2003$ & 2/28/2003 & 58 & N/A & & & & & \\
\hline \multicolumn{10}{|l|}{ MICHIGAN } \\
\hline First amnesty & 5/12/1986 & 6/30/1986 & 49 & $\$ 154,106$ & 11 & $\$ 16.88$ & 19 & $\$ 77.08$ & 17 \\
\hline Second amnesty & $5 / 15 / 2002$ & 6/30/2002 & 46 & $\$ 30,454$ & 37 & $\$ 3.03$ & 51 & $\$ 10.50$ & 52 \\
\hline MINNESOTA & 8/1/1984 & 10/31/1984 & 91 & $\$ 17,885$ & 41 & $\$ 4.30$ & 44 & $\$ 20.28$ & 43 \\
\hline \multicolumn{10}{|l|}{ MISSISSIPPI } \\
\hline First amnesty & 9/1/1986 & 11/30/1986 & 90 & $\$ 1,404$ & 58 & $\$ 0.54$ & 60 & $\$ 3.78$ & 59 \\
\hline Second amnesty & $9 / 1 / 2004$ & $12 / 31 / 2004$ & 121 & N/A & & & & & \\
\hline \multicolumn{10}{|l|}{ MISSOURI } \\
\hline First amnesty & 9/1/1983 & 10/31/1983 & 60 & $\$ 1,380$ & 59 & $\$ 0.28$ & 66 & $\$ 1.54$ & 65 \\
\hline Second amnesty & 8/1/2002 & $10 / 31 / 2002$ & 91 & $\$ 73,397$ & 19 & $\$ 12.92$ & 25 & $\$ 47.46$ & 24 \\
\hline Third amnesty & 8/1/2003 & $10 / 31 / 2003$ & 91 & $\$ 18,868$ & 40 & $\$ 3.30$ & 47 & $\$ 12.05$ & 49 \\
\hline
\end{tabular}


Table 3.6 Cont'd

\begin{tabular}{|c|c|c|c|c|c|c|c|c|c|}
\hline \multirow[b]{2}{*}{ Name of State } & \multicolumn{3}{|c|}{ Amnesty Period } & \multirow{2}{*}{$\begin{array}{c}\text { Amnesty } \\
\text { Collection } \\
2000 \$ \$^{\mathrm{a}} \\
(000)\end{array}$} & \multirow[b]{2}{*}{ Rank } & \multirow{2}{*}{$\begin{array}{c}\text { Amnesty } \\
\text { Collection } \\
\text { Per } \\
\text { Capita }\end{array}$} & \multirow[b]{2}{*}{ Rank } & \multirow{2}{*}{$\begin{array}{c}\text { Amnesty } \\
\text { Collection } \\
\text { per 100,000 } \\
\text { State Income }\end{array}$} & \multirow[b]{2}{*}{ Rank } \\
\hline & Begin & End & Days & & & & & & \\
\hline NEBRASKA & $8 / 1 / 2004$ & $10 / 31 / 2004$ & 91 & N/A & & & & & \\
\hline NEVADA & 2/1/2002 & 6/30/2002 & 149 & $\$ 7,013$ & 53 & $\$ 3.23$ & 48 & $\$ 10.97$ & 51 \\
\hline \multicolumn{10}{|l|}{ NEW HAMPSHIRE } \\
\hline First amnesty & $12 / 1 / 1997$ & 2/17/1998 & 78 & $\$ 13,994$ & 45 & $\$ 11.80$ & 28 & $\$ 38.41$ & 33 \\
\hline Second amnesty & $12 / 1 / 2001$ & $2 / 15 / 2002$ & 76 & $\$ 12,969$ & 47 & $\$ 10.30$ & 31 & $\$ 31.06$ & 38 \\
\hline \multicolumn{10}{|l|}{ NEW JERSEY } \\
\hline First amnesty & 9/10/1987 & 12/8/1987 & 89 & $\$ 254,796$ & 8 & $\$ 33.22$ & 5 & $\$ 120.76$ & 7 \\
\hline Second amnesty & 3/15/1996 & 6/1/1996 & 78 & $\$ 382,514$ & 4 & $\$ 47.76$ & 1 & $\$ 144.57$ & 3 \\
\hline Third amnesty & $4 / 15 / 2002$ & $6 / 10 / 2002$ & 56 & $\$ 266,016$ & 6 & $\$ 31.01$ & 7 & $\$ 81.96$ & 15 \\
\hline \multicolumn{10}{|l|}{ NEW MEXICO } \\
\hline First amnesty & 8/15/1985 & 11/13/1985 & 90 & $\$ 19,508$ & 39 & $\$ 13.56$ & 24 & $\$ 78.27$ & 16 \\
\hline Second amnesty & 8/16/1999 & $11 / 12 / 1999$ & 88 & $\$ 45,980$ & 30 & $\$ 26.43$ & 12 & $\$ 118.28$ & 8 \\
\hline \multicolumn{10}{|l|}{ NEW YORK } \\
\hline First amnesty & 11/1/1985 & 1/31/1986 & 91 & $\$ 563,230$ & 1 & $\$ 31.58$ & 6 & $\$ 125.32$ & 6 \\
\hline Second amnesty & $11 / 1 / 1996$ & $1 / 31 / 1997$ & 91 & $\$ 265,581$ & 7 & $\$ 14.64$ & 22 & $\$ 45.49$ & 25 \\
\hline Third amnesty & $11 / 18 / 2002$ & $1 / 31 / 2003$ & 74 & $\$ 549,726$ & 2 & $\$ 28.61$ & 10 & $\$ 83.66$ & 14 \\
\hline \multicolumn{10}{|l|}{ NORTH } \\
\hline CAROLINA & 9/1/1989 & 12/1/1989 & 91 & $\$ 47,863$ & 27 & $\$ 7.29$ & 38 & $\$ 34.72$ & 35 \\
\hline \multicolumn{10}{|l|}{ NORTH DAKOTA } \\
\hline First amnesty & 9/1/1983 & 11/30/1983 & 90 & $\$ 307$ & 68 & $\$ 0.45$ & 62 & $\$ 2.59$ & 62 \\
\hline Second amnesty & $10 / 1 / 2003$ & $1 / 31 / 2004$ & 122 & $\$ 6,392$ & 54 & $\$ 10.08$ & 32 & $\$ 38.17$ & 34 \\
\hline OHIO & $10 / 15 / 2001$ & $1 / 15 / 2002$ & 92 & $\$ 46,594$ & 29 & $\$ 4.08$ & 45 & $\$ 14.61$ & 47 \\
\hline \multicolumn{10}{|l|}{ OKLAHOMA } \\
\hline First amnesty & 7/1/1984 & 12/31/1984 & 183 & $\$ 20,545$ & 38 & $\$ 6.25$ & 41 & $\$ 33.23$ & 36 \\
\hline Second amnesty & $8 / 15 / 2002$ & $11 / 15 / 2002$ & 92 & N/A & & & & & \\
\hline PENNSYLVANIA & $10 / 13 / 1995$ & $1 / 10 / 1996$ & 89 & N/A & & & & & \\
\hline \multicolumn{10}{|l|}{ RHODE ISLAND } \\
\hline First amnesty & $10 / 15 / 1986$ & 1/12/1987 & 89 & $\$ 956$ & 62 & $\$ 0.97$ & 57 & $\$ 4.29$ & 57 \\
\hline Second amnesty & 4/15/1996 & 6/28/1996 & 74 & $\$ 8,417$ & 52 & $\$ 8.52$ & 34 & $\$ 32.10$ & 37 \\
\hline
\end{tabular}


Table 3.6 Cont'd

\begin{tabular}{|c|c|c|c|c|c|c|c|c|c|}
\hline \multirow[b]{2}{*}{ Name of State } & \multicolumn{3}{|c|}{ Amnesty Period } & \multirow{2}{*}{$\begin{array}{c}\text { Amnesty } \\
\text { Collection } \\
2000 \$^{\mathrm{a}} \\
(000)\end{array}$} & \multirow[b]{2}{*}{ Rank } & \multirow{2}{*}{$\begin{array}{c}\text { Amnesty } \\
\text { Collection } \\
\text { Per } \\
\text { Capita }\end{array}$} & \multirow[b]{2}{*}{ Rank } & \multirow{2}{*}{$\begin{array}{c}\text { Amnesty } \\
\text { Collection } \\
\text { per 100,000 } \\
\text { State Income }\end{array}$} & \multirow[b]{2}{*}{ Rank } \\
\hline & Begin & End & Days & & & & & & \\
\hline \multicolumn{10}{|l|}{ SOUTH CAROLINA } \\
\hline First amnesty & 9/1/1985 & 11/30/1985 & 90 & $\$ 10,184$ & 49 & $\$ 3.08$ & 50 & $\$ 18.43$ & 44 \\
\hline Second amnesty & $10 / 15 / 2002$ & $12 / 2 / 2002$ & 48 & $\$ 63,598$ & 22 & $\$ 15.49$ & 20 & $\$ 63.32$ & 20 \\
\hline SOUTH DAKOTA & 4/1/1999 & 5/15/1999 & 44 & $\$ 511$ & 65 & $\$ 0.70$ & 59 & $\$ 2.72$ & 61 \\
\hline \multicolumn{10}{|l|}{ TEXAS } \\
\hline First amnesty & 2/1/1984 & 2/29/1984 & 28 & $\$ 739$ & 64 & $\$ 0.05$ & 68 & $\$ 0.23$ & 68 \\
\hline Second amnesty & $3 / 11 / 2004$ & $3 / 31 / 2004$ & 20 & N/A & & & & $\$ 0.00$ & \\
\hline VERMONT & $5 / 15 / 1990$ & 6/25/1990 & 41 & $\$ 1,226$ & 61 & $\$ 2.17$ & 53 & $\$ 9.90$ & 53 \\
\hline \multicolumn{10}{|l|}{ VIRGINIA } \\
\hline First amnesty & 2/1/1990 & 3/31/1990 & 58 & $\$ 39,466$ & 31 & $\$ 6.35$ & 40 & $\$ 25.33$ & 40 \\
\hline Second amnesty & $9 / 2 / 2003$ & $11 / 3 / 2003$ & 62 & $\$ 92,737$ & 16 & $\$ 12.59$ & 26 & $\$ 39.55$ & 29 \\
\hline \multicolumn{10}{|l|}{ WEST VIRGINIA } \\
\hline First amnesty & 10/1/1986 & $12 / 31 / 1986$ & 91 & $\$ 14,689^{\mathrm{b}}$ & 44 & $\$ 7.80$ & 36 & $\$ 48.81$ & 22 \\
\hline Second amnesty & $9 / 1 / 2004$ & $10 / 31 / 2004$ & 60 & $\$ 13,465^{\mathrm{b}, \mathrm{c}}$ & 46 & $\$ 7.42$ & 37 & $\$ 30.95$ & 39 \\
\hline \multicolumn{10}{|l|}{ WISCONSIN } \\
\hline First amnesty & 9/15/1985 & $11 / 22 / 1985$ & 68 & $\$ 39,160$ & 32 & $\$ 8.25$ & 35 & $\$ 41.55$ & 28 \\
\hline Second amnesty & 6/15/1998 & 8/14/1998 & 60 & $\$ 32,030$ & 36 & $\$ 6.13$ & 42 & $\$ 22.28$ & 41 \\
\hline
\end{tabular}

Source: FTA, January 2005. http://www.taxadmin.org/fta/rate/amnesty1.html. Web access date: 05/08/05.

Notes: ${ }^{\mathrm{a}}$ Total and per capita tax amnesty collections in the table are reported in constant 2000 (dollars).

$\mathrm{b}$ These figures are based on correspondence with the West Virginia Tax Department.

c Figures of revenue collection in second amnesty are preliminary as of 05/04/2005. 
When we look at per capita figures, New Jersey (1996, \$47.75), Illinois (2003, 39.68) and Louisiana (2001, 37.85) have the three largest short-run tax amnesty revenue yields. On the other hand, per capita collections were less than $\$ 1$ in thirteen states with the three smallest per capita revenue yields in Missouri (1983, \$0.28), Louisiana (1987, $\$ 0.09)$ and Texas (1984, \$0.05). Similarly, when amnesty collections are controlled for state personal income, considerably different ranking of states is obtained. The top three tax amnesties in terms of revenue yields per $\$ 100,000$ state personal income are Kentucky (1988, \$200.34), Louisiana (2001, \$156.78) and New Jersey (2002, \$144.57).

\subsection{Empirical Analysis and Results}

I begin by performing two-way fixed and random effects regression analysis, using a panel of quarterly data on real tax revenue for all 50 states over the 1980-2002 period, resulting in 4,600 observations. Thus, the models include both state and time period controls. Descriptions of the variables, and data sources, can be found in Appendix VIII. Summary statistics are presented in Table 3.7. My dependent variable is the log of per capita total state tax revenue. ${ }^{29}$ As explanatory variables I include the variables of interest, i.e. the amnesty variables and other control variables to explain total tax revenue. These other control variables include the logs of personal income, the average personal income tax rate, the average corporate income tax rate, the sales tax

\footnotetext{
${ }^{29}$ When estimating revenue equations, a logarithmic transformation is used to make the equation linear for operational purposes. If revenue $(\mathrm{R})$ is equal to tax rate $(\mathrm{t})$ multiplied by tax base $(\mathrm{B})$, then $\log (\mathrm{R})=\log (\mathrm{t})+\log (\mathrm{B})$.
} 
Table 3.7 - Summary Statistics

\begin{tabular}{|c|c|c|c|c|c|}
\hline Variables & $\begin{array}{c}\text { No of } \\
\text { Observation }\end{array}$ & Mean & $\begin{array}{l}\text { Standard } \\
\text { Deviation }\end{array}$ & Minimum & Maximum \\
\hline Total Tax Revenue Per Capita & 4538 & 390.282 & 173.224 & 84 & 3729 \\
\hline $\begin{array}{l}\text { Personal Income Tax Revenue Per } \\
\text { Capita }\end{array}$ & 3918 & 130.518 & 71.558 & -27 & 484 \\
\hline $\begin{array}{l}\text { Corporate Income Tax Revenue Per } \\
\text { Capita }\end{array}$ & 4166 & 29.768 & 49.076 & -14 & 1076 \\
\hline Sales Tax Revenue Per Capita & 4085 & 131.246 & 54.555 & -9 & 449 \\
\hline Short-run Effect of Amnesty 1 & 4600 & 0.014 & 0.118 & 0 & 1 \\
\hline Short-run Effect of Amnesty 2 & 4600 & 0.006 & 0.076 & 0 & 1 \\
\hline Short-run Effect of Amnesty 3 & 4600 & 0.001 & 0.033 & 0 & 1 \\
\hline Long-run Effect of Amnesty 1 & 4600 & 0.508 & 0.500 & 0 & 1 \\
\hline Long-run Effect of Amnesty 2 & 4600 & 0.063 & 0.243 & 0 & 1 \\
\hline Long-run Effect of Amnesty 3 & 4600 & 0.005 & 0.071 & 0 & 1 \\
\hline $\begin{array}{l}\text { Time Difference between 1st \& 2nd } \\
\text { Amnesty (Short Run effect) }\end{array}$ & 4600 & 0.060 & 0.923 & 0 & 19 \\
\hline $\begin{array}{l}\text { Time Difference between 1st \& 2nd } \\
\text { Amnesty (Long Run effect) }\end{array}$ & 4600 & 0.421 & 2.085 & 0 & 19 \\
\hline Personal Income Per Capita & 4600 & 23051.500 & 4844.128 & 12620 & 42202 \\
\hline $\begin{array}{l}\text { Average of the Personal Income Tax } \\
\text { Rate }\end{array}$ & 3728 & 0.059 & 0.046 & 0.015 & 0.280 \\
\hline $\begin{array}{l}\text { Average of the Corporate Income Tax } \\
\text { Rate }\end{array}$ & 4140 & 0.068 & 0.019 & 0.019 & 0.127 \\
\hline Average of the Sales Tax Rate & 4140 & 0.048 & 0.011 & 0.02 & 0.08 \\
\hline Unemployment Rate & 4600 & 6.035 & 2.173 & 2.1 & 19.2 \\
\hline $\begin{array}{l}\text { Budget Surplus or Shortfall as a } \\
\text { percent of Total Tax Revenue }\end{array}$ & 4600 & 0.197 & 0.266 & -2.188 & 3.308 \\
\hline
\end{tabular}


rate, the unemployment rate, and budget surplus or shortfall as a percent of total tax revenue. $^{30}$ I include the budget surplus or shortfall variable to attempt to help correct for the tendency of states to offer amnesties during times of fiscal stress. However, I present the results both with and without this variable included given the potentially endogenous nature of it.

The main variables capture the impact of offering a tax amnesty on real tax revenue, in both the short run and long run. To do this I include two variables for each amnesty offered. The first captures the short-run effect, and is simply a dummy variable equal to one only during the period for which the amnesty is active (which can be one or more quarters). The second, to capture the long-run effect, is a dummy variable equal to zero prior to the offering of the tax amnesty and one for every period after the amnesty is offered, forever. The first of these two variables, the short run effect, captures any upward spike in the revenue collections during the period the amnesty is offered. This would be the revenue generated from the collection of back taxes during the amnesty. The second, the long run effect, captures any permanent shift in the mean of the series that begins with the date the amnesty is offered. This potentially includes two effects, the first being the evaders who now come back into the tax system, permanently increasing revenue, and the second being an increase in tax evasion as other taxpayers see the offering of the amnesty as a sign of a low cost of switching to tax evasion. Note,

\footnotetext{
30 The average corporate and personal income tax rates are computed as the simple average of the rates in all brackets in the state for that tax.
} 
however, that the true first period effect is the combined effect of both the short and long run coefficients.

Because I focus on how both the short-run and long-run impact of offering an amnesty change as amnesties are offered repeatedly, I include these two variables separately for the first, second, and third amnesties offered. Because of the use of a fixed (or random) effects model, and due to Louisiana being the only state to offer a fourth amnesty, it is not possible to include a separate variable for their fourth amnesty (due to perfect multicollinearity). Thus, Louisiana's fourth amnesty is excluded from the final analysis. ${ }^{31}$

It is expected that the initial (short-run) revenue brought in from overdue taxes will begin positive for the first amnesty, and then decline each time the amnesty is offered repeatedly. Thus, amnesties have a declining marginal benefit to the state offering them in terms of short-run revenue generated. It is possible, based on the review of the prior research, to be agnostic about the sign of the long-run effect variable. If the dominant effect of the amnesty is to bring evaders back into the tax system, then long-run revenue will rise. On the other hand, if the dominant effect is to discourage future compliance, increasing evasion, then long-run revenue will fall. If both effects are present, the long-run effect will be estimated close to zero. It is expected, however, that regardless of its initial value, the value for the second and third amnesties will be lower in

\footnotetext{
${ }^{31}$ Because revenue collection in Louisiana's fourth amnesty is considerably higher than its predecessors, also I run regressions ignoring its first, second or third amnesty one at a time. Although the coefficients of the short run and long run effect of amnesty 2 and 3 change sometimes from negative to positive, they are not significantly different from zero. The coefficient of short run effect of amnesty 1 remains always positive and significant. Likewise the coefficient of long run effect of amnesty 1 remains always negative and significant. The results are available from me upon request.
} 
value each time, relative to the long run effect of the first amnesty. This is due to both effects potentially becoming lower each time (fewer people brought back in each subsequent time, and as amnesty is repeated people come to expect it more likely again which reduces compliance). In addition, for repeated amnesties, the length of time that has passed since the prior amnesty might have implications for the short-run and long-run revenue effects. Thus, in some specifications, a dummy variable to capture this time difference is also included.

I run regression diagnostics to check for multicollinearity and heteroskedasticity in the models. No multicollinearity problems were detected. The matrix of correlation coefficients is presented in Appendix IX. However, a problem of heteroskedasticity was detected with personal income tax revenue data only. The results of the heteroskedasticity tests are presented in Appendix X.

Because my technique involves so many different dummy variables, I perform a sensitivity analysis by running specifications on important subsets of the data. In particular, I estimate the model on subsets of the data based on the number of amnesties offered by the state. I estimate the regression only among states with zero or one amnesty, then reestimate it expanding the sample to states with two amnesties, then again to states with three amnesties. The results of the fixed effects estimations are shown in Tables 3.8a and 3.8b. The Hausman test statistics, presented in the bottom row of the tables, allows us to use random effects model but as there is no significant gain using the 
random effects model, I use the fixed effects models. ${ }^{32}$ However, the alternative estimates from the random effects models are also presented in Appendix XIa and Appendix XIb.

${ }^{32}$ The parameter estimates obtained from fixed effects model are consistent under $H_{0}$ and $H_{a}$. The parameter estimates obtained from random effects model are inconsistent under $H_{a}$ but efficient under $H_{0}$. I perform the Hausman test of the null hypothesis that the difference in coefficients obtained from both fixed effects and random effects models are not systematic. The test statistics in all cases, except reported otherwise, suggest that we cannot reject the null hypothesis. 
Table 3.8a - Regression Results for Per Capita Total Tax Revenue

(Log of per capita total tax revenue as dependent variable and without budget surplus or shortfall variable)

\begin{tabular}{|c|c|c|c|c|c|}
\hline Variable & $\begin{array}{l}\text { States with one } \\
\text { Amnesty }\end{array}$ & $\begin{array}{c}\text { States with one } \\
\text { \& two } \\
\text { Amnesties }\end{array}$ & $\begin{array}{l}\text { States with one, } \\
\text { two, \& three } \\
\text { Amnesties }\end{array}$ & $\begin{array}{c}\text { States with one } \\
\text { \& two } \\
\text { Amnesties }\end{array}$ & $\begin{array}{l}\text { States with one, } \\
\text { two, \& three } \\
\text { Amnesties }\end{array}$ \\
\hline & (1) & (2) & (3) & (4) & (5) \\
\hline $\begin{array}{l}\text { Short-run effect of } \\
\text { Amnesty1 }\end{array}$ & $\begin{array}{l}.071^{* \star *} \\
(2.92)\end{array}$ & $\begin{array}{l}.056 * \star \star \\
(3.18)\end{array}$ & $\begin{array}{l}.046^{* * *} \\
(2.85)\end{array}$ & $\begin{array}{l}.056^{* \star *} \\
(3.17)\end{array}$ & $\begin{array}{l}.046^{* \star *} \\
(2.85)\end{array}$ \\
\hline $\begin{array}{l}\text { Short-run effect of } \\
\text { Amnesty2 }\end{array}$ & & $\begin{array}{l}-.046 \\
(1.42)\end{array}$ & $\begin{array}{l}-.013 \\
(0.54)\end{array}$ & $\begin{array}{l}-.029 \\
(0.44)\end{array}$ & $\begin{array}{l}.033 \\
(0.62)\end{array}$ \\
\hline $\begin{array}{l}\text { Short-run effect of } \\
\text { Amnesty3 }\end{array}$ & & & $\begin{array}{l}-.061 \\
(1.07)\end{array}$ & & $\begin{array}{l}-.064 \\
(1.13)\end{array}$ \\
\hline $\begin{array}{l}\text { Long-run effect of } \\
\text { Amnesty1 }\end{array}$ & $\begin{array}{l}-.063^{\star \star \star} \\
(5.92)\end{array}$ & $\begin{array}{l}-.042^{\star \star \star} \\
(4.91)\end{array}$ & $\begin{array}{l}-.034^{* \star *} \\
(4.15)\end{array}$ & $\begin{array}{l}-.041^{* \star *} \\
(4.78)\end{array}$ & $\begin{array}{l}-.034^{\star * *} \\
(4.11)\end{array}$ \\
\hline $\begin{array}{l}\text { Long-run effect of } \\
\text { Amnesty2 }\end{array}$ & & $\begin{array}{l}-.024^{*} \\
(1.76)\end{array}$ & $\begin{array}{l}-.038^{\star \star \star} \\
(3.45)\end{array}$ & $\begin{array}{l}-.093^{* * *} \\
(3.32)\end{array}$ & $\begin{array}{l}-.060^{* *} \\
(2.40)\end{array}$ \\
\hline $\begin{array}{l}\text { Long-run effect of } \\
\text { Amnesty3 }\end{array}$ & & & $\begin{array}{l}-.038 \\
(1.32)\end{array}$ & & $\begin{array}{l}-.031 \\
(1.04)\end{array}$ \\
\hline $\begin{array}{l}\text { Time difference } \\
\text { between } 1^{\text {st }} \& 2^{\text {nd }} \\
\text { Amnesty (Short Run } \\
\text { Effect) }\end{array}$ & & & & $\begin{array}{l}-.004 \\
(0.88)\end{array}$ & $\begin{array}{l}-.005 \\
(1.15)\end{array}$ \\
\hline $\begin{array}{l}\text { Time difference } \\
\text { between } 1^{\text {st }} \& 2^{\text {nd }} \\
\text { Amnesty (Long Run } \\
\text { Effect) }\end{array}$ & & & & $\begin{array}{l}.007^{* \star *} \\
(2.82)\end{array}$ & $\begin{array}{c}.002 \\
(0.98)\end{array}$ \\
\hline $\begin{array}{l}\text { Log of Per Capita } \\
\text { Personal Income }\end{array}$ & $\begin{array}{l}.895^{* * *} \\
(10.03)\end{array}$ & $\begin{array}{l}.981^{* * *} \\
(13.81)\end{array}$ & $\begin{array}{l}.966^{* * *} \\
(14.83)\end{array}$ & $\begin{array}{l}.960^{* *} \\
(13.46)\end{array}$ & $\begin{array}{l}.963^{* * *} \\
(14.74)\end{array}$ \\
\hline $\begin{array}{l}\text { Log of Personal } \\
\text { Income Tax Rate }\end{array}$ & $\begin{array}{c}-.002 \\
(0.16)\end{array}$ & $\begin{array}{l}-.027^{* *} \\
(2.28)\end{array}$ & $\begin{array}{l}-.006 \\
(0.52)\end{array}$ & $\begin{array}{l}-.027^{* *} \\
(2.33)\end{array}$ & $\begin{array}{l}-.005 \\
(0.48)\end{array}$ \\
\hline $\begin{array}{l}\text { Log of Corporate } \\
\text { Income Tax Rate }\end{array}$ & $\begin{array}{l}.071^{* *} \\
(2.01)\end{array}$ & $\begin{array}{l}.011 \\
(0.44)\end{array}$ & $\begin{array}{l}.042^{*} \\
(1.86)\end{array}$ & $\begin{array}{c}.007 \\
(0.29)\end{array}$ & $\begin{array}{l}.040^{*} \\
(1.78)\end{array}$ \\
\hline Log of Sales Tax Rate & $\begin{array}{l}.187^{* \star *} \\
(5.51)\end{array}$ & $\begin{array}{l}.140^{* * *} \\
(6.06)\end{array}$ & $\begin{array}{l}.134^{\star * *} \\
(6.11)\end{array}$ & $\begin{array}{l}.139 * \star \star \\
(6.03)\end{array}$ & $\begin{array}{l}.134^{\star * \star} \\
(6.12)\end{array}$ \\
\hline $\begin{array}{l}\text { Log of unemployment } \\
\text { rate }\end{array}$ & $\begin{array}{l}-.056^{* * *} \\
(3.06)\end{array}$ & $\begin{array}{l}-.059^{* * *} \\
(4.36)\end{array}$ & $\begin{array}{c}-.069^{* * *} \\
(5.70)\end{array}$ & $\begin{array}{c}-.060^{* * *} \\
(4.47)\end{array}$ & $\begin{array}{c}-.070^{* * *} \\
(5.76)\end{array}$ \\
\hline Constant & $\begin{array}{c}-2.119 * \star \\
(2.28)\end{array}$ & $\begin{array}{c}-3.402^{* * *} \\
(4.75)\end{array}$ & $\begin{array}{c}-3.129^{* * *} \\
(4.78)\end{array}$ & $\begin{array}{c}-3.205^{* * *} \\
(4.46)\end{array}$ & $\begin{array}{c}-3.095^{* * *} \\
(4.72)\end{array}$ \\
\hline $\mathrm{R}^{2}$ & 0.633 & 0.540 & 0.597 & 0.543 & 0.598 \\
\hline No of Observations & 1648 & 2917 & 3418 & 2917 & 3418 \\
\hline $\begin{array}{l}\text { Model Suggested by } \\
\text { Hausman Test }\end{array}$ & Fixed Effects & Fixed Effects & Fixed Effects & Fixed Effects & Fixed Effects \\
\hline$\chi^{2}$ value & $\chi^{2}(94)=5.21$ & $\chi^{2}(96)=8.97$ & $\chi^{2}(98)=7.87$ & $\chi^{2}(98)=8.17$ & $\chi^{2}(100)=7.23$ \\
\hline
\end{tabular}

Notes: Figures in parenthesis are absolute t-statistics, ${ }^{* * *}$ indicates 1 percent significance level, ${ }^{* *}$ indicates 5 percent significance level, *indicates 10 percent significance level. 
Table 3.8b - Regression Results for Per Capita Total Tax Revenue (Log of per capita total tax revenue as dependent variable and with budget surplus or shortfall variable)

\begin{tabular}{|c|c|c|c|c|c|}
\hline Variable & $\begin{array}{l}\text { States with one } \\
\text { Amnesty }\end{array}$ & $\begin{array}{c}\text { States with one } \\
\text { \& two } \\
\text { Amnesties }\end{array}$ & $\begin{array}{l}\text { States with one, } \\
\text { two, \& three } \\
\text { Amnesties }\end{array}$ & $\begin{array}{c}\text { States with one } \\
\text { \& two } \\
\text { Amnesties }\end{array}$ & $\begin{array}{l}\text { States with one, } \\
\text { two, \& three } \\
\text { Amnesties }\end{array}$ \\
\hline & (1) & (2) & (3) & (4) & (5) \\
\hline $\begin{array}{l}\text { Short-run effect of } \\
\text { Amnesty1 }\end{array}$ & $\begin{array}{l}.070^{* * *} \\
(2.87)\end{array}$ & $\begin{array}{l}.057^{* \star *} \\
(3.24)\end{array}$ & $\begin{array}{l}.045^{* \star \star} \\
(2.86)\end{array}$ & $\begin{array}{l}.057^{* \star *} \\
(3.23)\end{array}$ & $\begin{array}{l}.046^{* * *} \\
(2.86)\end{array}$ \\
\hline $\begin{array}{l}\text { Short-run effect of } \\
\text { Amnesty2 }\end{array}$ & & $\begin{array}{l}-.041 \\
(1.25)\end{array}$ & $\begin{array}{c}-.010 \\
(0.42) \\
\end{array}$ & $\begin{array}{l}-.036 \\
(0.56) \\
\end{array}$ & $\begin{array}{l}.030 \\
(0.57)\end{array}$ \\
\hline $\begin{array}{l}\text { Short-run effect of } \\
\text { Amnesty3 }\end{array}$ & & & $\begin{array}{l}-.048 \\
(0.85)\end{array}$ & & $\begin{array}{l}-.052 \\
(0.92)\end{array}$ \\
\hline $\begin{array}{l}\text { Long-run effect of } \\
\text { Amnesty1 }\end{array}$ & $\begin{array}{l}-.062^{\star \star *} \\
(5.90)\end{array}$ & $\begin{array}{l}-.043^{* \star \star} \\
(5.02)\end{array}$ & $\begin{array}{l}-.034^{\star \star \star} \\
(4.21)\end{array}$ & $\begin{array}{l}-.042^{* \star \star} \\
(4.89)\end{array}$ & $\begin{array}{l}-.034^{\star \star \star} \\
(4.16)\end{array}$ \\
\hline $\begin{array}{l}\text { Long-run effect of } \\
\text { Amnesty2 }\end{array}$ & & $\begin{array}{l}-.025^{*} \\
(1.85)\end{array}$ & $\begin{array}{c}-.041^{* \star *} \\
(3.72)\end{array}$ & $\begin{array}{c}-.103^{* \star *} \\
(3.67)\end{array}$ & $\begin{array}{c}-.067^{* \star *} \\
(2.71)\end{array}$ \\
\hline $\begin{array}{l}\text { Long-run effect of } \\
\text { Amnesty3 }\end{array}$ & & & $\begin{array}{l}-.050^{*} \\
(1.72)\end{array}$ & & $\begin{array}{l}-.041 \\
(1.39)\end{array}$ \\
\hline $\begin{array}{l}\text { Time difference } \\
\text { between } 1^{\text {st }} \& 2^{\text {nd }} \\
\text { Amnesty (Short Run } \\
\text { Effect) }\end{array}$ & & & & $\begin{array}{l}-.004 \\
(0.72)\end{array}$ & $\begin{array}{l}-.004 \\
(1.06)\end{array}$ \\
\hline $\begin{array}{l}\text { Time difference } \\
\text { between } 1^{\text {st }} \& 2^{\text {nd }} \\
\text { Amnesty (Long Run } \\
\text { Effect) }\end{array}$ & & & & $\begin{array}{l}.008^{* \star *} \\
(3.18)\end{array}$ & $\begin{array}{l}.003 \\
(1.19)\end{array}$ \\
\hline $\begin{array}{l}\text { Log of Per Capita } \\
\text { Personal Income }\end{array}$ & $\begin{array}{l}.898^{* * *} \\
(10.08)\end{array}$ & $\begin{array}{l}.987^{* * *} \\
(13.93)\end{array}$ & $\begin{array}{l}.970^{* * *} \\
(14.93)\end{array}$ & $\begin{array}{l}.964^{* * *} \\
(13.55)\end{array}$ & $\begin{array}{l}.966^{* * *} \\
(14.82)\end{array}$ \\
\hline $\begin{array}{l}\text { Log of Personal } \\
\text { Income Tax Rate }\end{array}$ & $\begin{array}{l}-.004 \\
(0.34)\end{array}$ & $\begin{array}{l}-.027^{* *} \\
(2.29)\end{array}$ & $\begin{array}{l}-.006 \\
(0.58)\end{array}$ & $\begin{array}{l}-.028^{* *} \\
(2.35)\end{array}$ & $\begin{array}{l}-.006 \\
(0.53)\end{array}$ \\
\hline $\begin{array}{l}\text { Log of Corporate } \\
\text { Income Tax Rate }\end{array}$ & $\begin{array}{l}.076^{\star *} \\
(2.14)\end{array}$ & $\begin{array}{l}.010 \\
(0.38)\end{array}$ & $\begin{array}{l}.039^{*} \\
(1.75)\end{array}$ & $\begin{array}{l}.005 \\
(0.21)\end{array}$ & $\begin{array}{l}.037^{*} \\
(1.65)\end{array}$ \\
\hline Log of Sales Tax Rate & $\begin{array}{l}.170^{* \star *} \\
(4.90)\end{array}$ & $\begin{array}{l}.137^{* * *} \\
(5.93)\end{array}$ & $\begin{array}{l}.131^{\star \star \star} \\
(5.99)\end{array}$ & $\begin{array}{l}.136^{\star \star \star} \\
(5.89)\end{array}$ & $\begin{array}{l}.131^{\star \star \star} \\
(5.99)\end{array}$ \\
\hline $\begin{array}{l}\text { Log of unemployment } \\
\text { rate }\end{array}$ & $\begin{array}{l}-.045^{\star *} \\
(2.47)\end{array}$ & $\begin{array}{l}-.048^{* \star \star} \\
(3.50)\end{array}$ & $\begin{array}{l}-.059^{\star \star \star} \\
(4.74)\end{array}$ & $\begin{array}{l}-.049^{* \star \star} \\
(3.56)\end{array}$ & $\begin{array}{c}-.060^{* \star *} \\
(4.80)\end{array}$ \\
\hline $\begin{array}{l}\text { Budget Surplus or } \\
\text { Shortfall as a percent } \\
\text { of Total Tax Revenue }\end{array}$ & $\begin{array}{l}.071^{\star *} \\
(2.49)\end{array}$ & $\begin{array}{l}.066^{\star \star \star} \\
(3.68)\end{array}$ & $\begin{array}{l}.067^{\star \star *} \\
(3.98)\end{array}$ & $\begin{array}{l}.071^{* \star *} \\
(3.93)\end{array}$ & $\begin{array}{l}.068^{\star \star \star} \\
(4.00)\end{array}$ \\
\hline Constant & $\begin{array}{c}-2.197^{* *} \\
(2.36)\end{array}$ & $\begin{array}{c}-3.481^{* * *} \\
(4.87)\end{array}$ & $\begin{array}{c}-3.189^{* * *} \\
(4.88)\end{array}$ & $\begin{array}{c}-3.263^{* * *} \\
(4.55)\end{array}$ & $\begin{array}{c}-3.146^{* * *} \\
(4.81)\end{array}$ \\
\hline $\mathrm{R}^{2}$ & 0.631 & 0.540 & 0.597 & 0.544 & 0.598 \\
\hline No of Observations & 1648 & 2917 & 3418 & 2917 & 3418 \\
\hline $\begin{array}{l}\text { Model suggested by } \\
\text { Hausman test }\end{array}$ & Fixed Effects & Fixed Effects & Fixed Effects & Fixed Effects & Fixed Effects \\
\hline$\chi^{2}$ value & $\chi^{2}(95)=3.89$ & $\chi^{2}(97)=8.10$ & $\chi^{2}(99)=7.94$ & $\chi^{2}(99)=7.03$ & $\chi^{2}(101)=6.21$ \\
\hline
\end{tabular}

Notes: Figures in parenthesis are absolute t-statistics, $* * *$ indicates 1 percent significance level, $* *$ indicates 5 percent significance level, *indicates 10 percent significance level. 
Table 3.8a presents the result of both the fixed and random effects estimations on the specification excluding the budget shortfall variable, while Table $3.8 \mathrm{~b}$ shows the results with this variable included. Because this additional variable is significant, and helps to control for the potential bias introduced because amnesties are likely to be timed during periods of fiscal stress, I prefer these estimates to the ones in Table 8a, although it makes only a small difference in the main coefficients of interest. Comparing the first three columns in Tables 8a and 8b, the results are robust to whether I include or exclude the states that have offered multiple amnesties. Focusing on the final two columns, where I control for the time elapsed between cases of multiple amnesties, these variables are generally insignificant, with the one significant result (the long run effect being less harmful given a longer time lag), dropping out when states with more than two amnesties are included. Because of the non-robust nature of the time lag variables, I tend to prefer what I consider the most appropriate 'full' model, which appears in Column (3) of Table 8b. The estimates from that model are the ones I will discuss in detail.

The significant, positive short-run coefficient estimate for amnesty 1 can be interpreted to suggest that the average impact of offering the first amnesty in a state is a 4.5 percent increase in real per capita tax revenue during the period of the amnesty due to the increased collections of previous evaders. The significant, negative long-run coefficient estimate for amnesty 1 can be interpreted to suggest that the long run impact of offering this first tax amnesty is significantly negative on revenue, resulting in about a 3.4 percent ongoing loss each period after the amnesty due to reduced compliance. Actually, the way the empirical model is constructed the true first period impact of the 
amnesty would be the short run inflow of short run revenue and also the long run revenue loss combined. After the first period, only the long-run impact remains. The results for the short and long-run effects of the second amnesty (amnesty 2) are exactly as anticipated. The second amnesty does not produce as much short run revenue (in fact, the results are insignificantly different from zero), but does produce a significant and negative long run effect that is greater than the negative long run effect for the first amnesty. Finally, when a state offers a third amnesty, again there is no significant short run revenue produced, and again the negative long run revenue loss is significant, and larger than it was for the second and first amnesties.

Based on these results, it can be strongly concluded that if a state is considering offering a tax amnesty to raise total tax revenue, the impact will depend on whether the state has previously offered an amnesty, and that it will probably never be a good idea at all. On average, first-time tax amnesties do tend to produce a significant 4 to 5 percent increase in revenue during the period the amnesty is being offered. They, however, also tend to discourage compliance to the magnitude of 3 percent per period, from then on. This certainly doesn’t seem like a worthwhile tradeoff, without assuming a fantastically large discount rate. The public choice literature, however, is filled with examples of shortsighted political behavior that could be consistent in explaining why states would still adopt an amnesty given these numbers.

On average, if a state has already offered one previous amnesty, and is considering running a second, they will likely see only a small (insignificant) increase in revenue during the amnesty period, followed by a significant, and larger, negative effect 
on long run revenue. The third amnesty continues this trend, with little short run revenue and larger long run revenue losses. These results are consistent with my expectations, and likely make sense to most tax researchers and practitioners. Tax amnesties are similar to the story of the boy who cried wolf. When they are offered on a repeated basis, they tend to discourage compliance to a greater extent than if they are only offered once. In addition, the revenue boost produced by an amnesty as former evaders pay up their tax liabilities during the amnesty period is significant only the first time a state offers an amnesty. This would suggest that the first amnesty to a great extent brings most evaders back into the system that would be willing to do so, and there is little benefit from repeating the amnesty within a short window of time.

\subsection{Effect of Enforcement and Penalty on State Tax Amnesty}

One difference across states that is not controlled for in the previous regressions is whether the state increased penalties and/or enforcement efforts in conjunction with the amnesty. This could potentially alter the revenue impact of the amnesty. Table 3.9, from Alm and Beck (1991), offers data on whether states increased penalties and/or enforcement efforts in conjunction with their amnesties during the 1982-1988 period. In an effort to assess what difference this makes, Tables 3.10a and 3.10b show the results from the models, run only on the subsample of one amnesty states during this 1982-1988 period, with separate regressions performed for each category of penalty/enforcement 
combination except funding for enforcement only (because not enough states in this group for estimation). ${ }^{33}$

Table 3.9 - Enforcement and Penalty Information of State Tax Amnesty Program (1982-1988)

\begin{tabular}{|l|c|l|}
\hline \multicolumn{1}{|c|}{ Category } & $\begin{array}{c}\text { No of } \\
\text { States }\end{array}$ & \multicolumn{1}{|c|}{ State Amnesties } \\
\hline $\begin{array}{l}\text { Increase in both penalties and funding } \\
\text { for enforcement }\end{array}$ & 14 & $\begin{array}{l}\text { Alabama (1984), Arizona (1982-83), California } \\
\text { (1984-85), Colorado (1985), Illinois (1984), Iowa } \\
\text { (1986), Maryland (1987), Massachusetts (1983-84), } \\
\text { Michigan (1986), New Jersey (1987), New York } \\
\text { (1985-86), Oklahoma (1984), South Carolina } \\
\text { (1985), Wisconsin }\end{array}$ \\
\hline Increase in penalties only & 7 & $\begin{array}{l}\text { Arkansas (1987), Florida (1987 and 1988), } \\
\text { Mississippi (1986), Rhode Island (1987), Texas } \\
\text { (1984), West Virginia (1986) }\end{array}$ \\
\hline $\begin{array}{l}\text { Increase in funding for enforcement } \\
\text { only }\end{array}$ & 3 & $\begin{array}{l}\text { Kansas (1984), Louisiana (1985), New Mexico } \\
\text { (1985) }\end{array}$ \\
\hline $\begin{array}{l}\text { No increase in penalties or funding for } \\
\text { enforcement }\end{array}$ & 5 & $\begin{array}{l}\text { Idaho (1983), Louisiana (1987), Minnesota (1984), } \\
\text { Missouri (1983), North Dakota (1983) }\end{array}$ \\
\hline
\end{tabular}

Source: Alm and Beck (1991)

The regression results are presented in Table 3.10a and Table 3.10b. ${ }^{34}$ The results from these estimations confirm what I expected with regard to the long-run revenue effect, but appear opposite of my expectations with regard to the short-run effect. States who use an increase in both penalties and enforcement tend to have a smaller long-run

\footnotetext{
${ }^{33}$ Enforcement data is not available for all states tax amnesties. The table based on Alm and Beck (1991), lists name of states which increased penalties or greater funding for enforcement of the tax regime after the conclusion of tax amnesties prior to 1988. Because many states listed offered a second or third amnesty since 1988, I restrict the sample to the states which offered their first tax amnesty prior to 1988 and/or which offered a second amnesty after 2002. Similarly, because California (1983-84) and Idaho (1983) conducted amnesties for specific taxes only, they are also excluded from the analysis.

${ }^{34}$ Asymptotic assumption for Hausman test was not satisfied for any of these categories of states, therefore, only fixed effects results are reported.
} 
revenue loss (implying fewer people become evaders in anticipation of a future amnesty). States who increased penalties also had smaller negative long-run effects, but not nearly as large as when these higher penalties are combined with increased enforcement. Interestingly, the short-run revenue effect estimates suggest that the largest short-run revenue gain happens when there is no increase in penalties or enforcement, and the smallest short-run gains happen when they are both increased. The results are somewhat puzzling; however there are two possible explanations appealing. First, there is likely a selection bias in terms of which states choose to increase penalties and/or enforcement. Perhaps it is those states who have been the easiest on evaders in the past (and thus had a high level of evasion), or possibly those who most increased these items may be the states whose residents are costliest (or hardest) to get to comply with the tax code. Alternatively, these results simply might not be as reliable as the ones earlier due to the limited nature of the sample on which this data was available. 


\section{Table 3.10a - Regression Results for Increase in Enforcement and/or Penalty on Amnesty \\ (Log of per capita total tax revenue as dependent variable)}

\begin{tabular}{|c|c|c|c|}
\hline Variable & $\begin{array}{l}\text { Increase in both } \\
\text { penalties and funding } \\
\text { for enforcement }\end{array}$ & $\begin{array}{l}\text { Increase in } \\
\text { penalties only }\end{array}$ & $\begin{array}{l}\text { No increase in } \\
\text { penalties or funding } \\
\text { for enforcement }\end{array}$ \\
\hline & (1) & (2) & (3) \\
\hline $\begin{array}{l}\text { Short-run effect of } \\
\text { Amnesty1 }\end{array}$ & $\begin{array}{l}.088^{*} \\
(1.77)\end{array}$ & $\begin{array}{l}.140^{*} \\
(2.43)\end{array}$ & $\begin{array}{l}.208 * \star * \\
(3.13)\end{array}$ \\
\hline $\begin{array}{l}\text { Long-run effect of } \\
\text { Amnesty1 }\end{array}$ & $\begin{array}{c}-.055^{\star \star \star} \\
(2.84)\end{array}$ & $\begin{array}{l}-.118^{* * *} \\
(5.78)\end{array}$ & $\begin{array}{l}-.144^{\star * *} \\
(4.48)\end{array}$ \\
\hline $\begin{array}{l}\text { Log of Per Capita } \\
\text { Personal Income }\end{array}$ & $\begin{array}{l}.834 * \star \star \\
(5.24)\end{array}$ & $\begin{array}{l}.972 * \star \star \\
(6.36)\end{array}$ & $\begin{array}{l}.926 * \star \star \\
(5.89)\end{array}$ \\
\hline $\begin{array}{l}\text { Log of Personal Income } \\
\text { Tax Rate }\end{array}$ & $\begin{array}{l}-.026 \\
(1.29)\end{array}$ & $\begin{array}{c}.017 \\
(0.91)\end{array}$ & $\begin{array}{l}-.046^{\star * *} \\
(2.53)\end{array}$ \\
\hline $\begin{array}{l}\text { Log of Corporate } \\
\text { Income Tax Rate }\end{array}$ & $\begin{array}{l}-.048 \\
(0.82)\end{array}$ & $\begin{array}{l}-.068 \\
(1.19)\end{array}$ & $\begin{array}{c}-.074 \\
(1.10)\end{array}$ \\
\hline Log of Sales Tax Rate & $\begin{array}{l}.135^{\star *} \\
(2.10)\end{array}$ & $\begin{array}{l}323^{* * *} \\
(5.03)\end{array}$ & $\begin{array}{c}.114 \\
(1.51)\end{array}$ \\
\hline $\begin{array}{l}\text { Log of unemployment } \\
\text { rate }\end{array}$ & $\begin{array}{l}-.045 \\
(1.60)\end{array}$ & $\begin{array}{l}-.073^{* \star \star} \\
(2.81)\end{array}$ & $\begin{array}{l}-.080^{*} \\
(2.53)\end{array}$ \\
\hline Constant & $\begin{array}{l}-2.189 \\
(1.35)\end{array}$ & $\begin{array}{c}-2.725^{\star} \\
(1.74)\end{array}$ & $\begin{array}{c}-3.115^{* *} \\
(1.96)\end{array}$ \\
\hline $\mathrm{R}^{2}$ & 0.523 & 0.574 & 0.512 \\
\hline No of Observations & 733 & 642 & 548 \\
\hline Estimated Model & Fixed Effects & Fixed Effects & Fixed Effects \\
\hline $\begin{array}{l}\text { Name of states } \\
\text { included: }\end{array}$ & $\begin{array}{c}\text { Alabama, Colorado, } \\
\text { Illinois and Iowa + states } \\
\text { with no amnesties }\end{array}$ & $\begin{array}{c}\text { Arkansas, Florida, } \\
\text { Mississippi, Texas } \\
\text { and West Virginia + } \\
\text { states with no } \\
\text { amnesties }\end{array}$ & $\begin{array}{c}\text { Minnesota and North } \\
\text { Dakota + states with no } \\
\text { amnesties }\end{array}$ \\
\hline
\end{tabular}

Notes: Figures in parenthesis are absolute t-statistics, ***indicates 1 percent significance level, **indicates 5 percent significance level, *indicates 10 percent significance level. 


\section{Table 3.10b - Regression Results for Increase in Enforcement and/or Penalty on Amnesty}

(Log of per capita total tax revenue as dependent variable)

\begin{tabular}{|c|c|c|c|}
\hline Variable & $\begin{array}{l}\text { Increase in both } \\
\text { penalties and funding } \\
\text { for enforcement }\end{array}$ & $\begin{array}{l}\text { Increase in } \\
\text { penalties only }\end{array}$ & $\begin{array}{l}\text { No increase in } \\
\text { penalties or funding } \\
\text { for enforcement }\end{array}$ \\
\hline & (1) & (2) & (3) \\
\hline $\begin{array}{l}\text { Short-run effect of } \\
\text { Amnesty1 }\end{array}$ & $\begin{array}{l}.088^{*} \\
(1.77)\end{array}$ & $\begin{array}{l}.139^{* *} \\
(2.40)\end{array}$ & $\begin{array}{l}.204^{\star \star \star} \\
(3.07)\end{array}$ \\
\hline $\begin{array}{l}\text { Long-run effect of } \\
\text { Amnesty1 }\end{array}$ & $\begin{array}{l}-.062^{\star \star \star} \\
(3.18)\end{array}$ & $\begin{array}{c}-.118^{* \star \star} \\
(5.78)\end{array}$ & $\begin{array}{c}-.149^{* * *} \\
(4.60)\end{array}$ \\
\hline $\begin{array}{l}\text { Log of Per Capita } \\
\text { Personal Income }\end{array}$ & $\begin{array}{l}.858^{* * *} \\
(5.4 \odot)\end{array}$ & $\begin{array}{l}.976^{* \star *} \\
(6.38)\end{array}$ & $\begin{array}{l}.935^{* \star *} \\
(5.95)\end{array}$ \\
\hline $\begin{array}{l}\text { Log of Personal Income } \\
\text { Tax Rate }\end{array}$ & $\begin{array}{l}-.025 \\
(1.23)\end{array}$ & $\begin{array}{c}.017 \\
(\odot .91)\end{array}$ & $\begin{array}{l}-.047^{* *} \\
(2.55)\end{array}$ \\
\hline $\begin{array}{l}\text { Log of Corporate } \\
\text { Income Tax Rate }\end{array}$ & $\begin{array}{l}-.065 \\
(1.11)\end{array}$ & $\begin{array}{l}-.065 \\
(1.13)\end{array}$ & $\begin{array}{l}-.090 \\
(1.32)\end{array}$ \\
\hline Log of Sales Tax Rate & $\begin{array}{l}.136^{\star *} \\
(2.12)\end{array}$ & $\begin{array}{l}.315^{\star \star \star} \\
(4.76)\end{array}$ & $\begin{array}{l}.140^{*} \\
(1.79)\end{array}$ \\
\hline $\begin{array}{l}\text { Log of unemployment } \\
\text { rate }\end{array}$ & $\begin{array}{l}-.036 \\
(1.27)\end{array}$ & $\begin{array}{l}-.068^{* *} \\
(2.50)\end{array}$ & $\begin{array}{l}-.093^{* * *} \\
(2.81)\end{array}$ \\
\hline $\begin{array}{l}\text { Budget Surplus or } \\
\text { Shortfall as a percent of } \\
\text { Total Tax Revenue }\end{array}$ & $\begin{array}{l}.093^{* *} \\
(2.28)\end{array}$ & $\begin{array}{c}.027 \\
(0.53)\end{array}$ & $\begin{array}{l}-.067 \\
(1.26)\end{array}$ \\
\hline Constant & $\begin{array}{l}-2.456 \\
(1.51) \\
\end{array}$ & $\begin{array}{l}-2.787^{\star} \\
(1.77) \\
\end{array}$ & $\begin{array}{c}-3.173^{* *} \\
(2.00) \\
\end{array}$ \\
\hline $\mathrm{R}^{2}$ & 0.520 & 0.576 & 0.500 \\
\hline No of Observations & 733 & 642 & 548 \\
\hline Model & Fixed Effects & Fixed Effects & Fixed Effects \\
\hline $\begin{array}{l}\text { Name of states } \\
\text { included: }\end{array}$ & $\begin{array}{c}\text { Alabama, Colorado, } \\
\text { Illinois and Iowa + states } \\
\text { with no amnesties }\end{array}$ & $\begin{array}{c}\text { Arkansas, Florida, } \\
\text { Mississippi, Texas } \\
\text { and West Virginia + } \\
\text { states with no } \\
\text { amnesties }\end{array}$ & $\begin{array}{c}\text { Minnesota and North } \\
\text { Dakota + states with no } \\
\text { amnesties }\end{array}$ \\
\hline
\end{tabular}

Notes: Figures in parenthesis are absolute t-statistics, ${ }^{* * *}$ indicates 1 percent significance level, **indicates 5 percent significance level, *indicates 10 percent significance level. 


\subsection{Effects of Allowing Known Delinquents on State Tax Amnesty}

One argument for allowing known delinquents to participate in the amnesty is that amnesty brings these people back into the tax system enlarging the tax base and thereby increases the tax revenue both in the short run and in the long run. However, Joulfaian (1988), studying 1983 Massachusetts amnesty, concludes that contrary to this argument, habitual evaders, or evaders who pay taxes but under-report them, generally did not participate in the amnesty program. Table 3.11 provides information on whether states allowed known delinquents to participate in their amnesties during the 1982-2004 period. In order to assess what difference allowing known delinquents to participate in the amnesty makes, I also perform two separate regressions for each category (i) if known delinquents were allowed to participate and (ii) if they were not allowed to participate; I didn't run a third separate regression for the category if the delinquent status was unknown. The regression results are presented in Table 3.12. ${ }^{35}$

The results show that allowing known delinquents to participate do not have desired effects. States that allowed known delinquents tend to have a higher long-run revenue losses. Furthermore, the short-run revenue gains happen when states didn’t allow known delinquents to participate. Two explanations for such results are plausible. Firstly, tax delinquents are reluctant to come back into the tax system, and secondly, even if they come back by means of government intervention i.e. through amnesty, they do not remain in the system for long.

\footnotetext{
${ }^{35}$ Asymptotic assumption for Hausman test was not satisfied for some of the categories of states, therefore, only fixed effects results are reported.
} 
Table 3.11 - Delinquent Participation Information of State Tax Amnesty Program (1982-2004)

\begin{tabular}{|l|c|l|}
\hline \multicolumn{1}{|c|}{ Category } & $\begin{array}{c}\text { No of } \\
\text { States }\end{array}$ & \multicolumn{1}{c|}{ State Amnesties } \\
\hline $\begin{array}{l}\text { Known delinquents } \\
\text { allowed to participate }\end{array}$ & 42 & $\begin{array}{l}\text { California }^{\text {a }} \text { (1984-85), Connecticut (1990 and 1995), Georgia (1992), } \\
\text { Iowa (1986), Illinois (1984), Kansas (2003),Louisiana (2001), } \\
\text { Massachusetts (1984, 2002 and 2003) Maryland (1987 and 2001), } \\
\text { Maine (1990), Michigan (1986 and 2002), Minnesota (1984), Missouri } \\
\text { (2002 and 2003), New Hampshire (1997-98 and 2001-02), New } \\
\text { Mexico (1999), New Jersey (1987, 1996 and 2002), New York (1985- } \\
\text { 86, 1996-97 and 2002-03), North Carolina (1989), Oklahoma (1984 } \\
\text { and 2002), Pennsylvania (1996), Rhode Island (1996), South Carolina } \\
\text { (1985 and 2002), South Dakota (1999), Vermont (1990), Virginia } \\
\text { (1990 and 2003), West Virginia (1986), Wisconsin (1985 and 1998) }\end{array}$ \\
\hline $\begin{array}{l}\text { Known delinquents not } \\
\text { allowed to participate }\end{array}$ & 25 & $\begin{array}{l}\text { Alabama (1984), Arizona (1982-83 and 2002), Arkansas (1987), } \\
\text { California (1984-85), Colorado (1985), Florida (1987 and 1988), } \\
\text { Idaho (1983), Kansas (1984), Kentucky (1988 and 2002), Louisiana } \\
\text { (1985, 1987 and 1998), Mississippi (1986 and 2004), Missouri (1983), } \\
\text { Nebraska (2004), New Mexico (1985), North Dakota (1983), Ohio } \\
\text { (2001-02), Rhode Island (1987), Texas (1984 and 2004) }\end{array}$ \\
\hline $\begin{array}{l}\text { Delinquents participation } \\
\text { status unknown }\end{array}$ & 10 & $\begin{array}{l}\text { Arizona (2003), Arkansas (2004), Colorado (2003), Connecticut } \\
\text { (2002), Florida (2003), Illinois (2003), Maine (2003), Nevada (2002), } \\
\text { North Dakota (2003-04), West Virginia (2004) }\end{array}$ \\
\hline
\end{tabular}

Source: FTA, January 2005. http://www.taxadmin.org/fta/rate/amnesty1.html (Web page access date $5 / 8 / 2005)$.

Notes: $\quad{ }^{a}$ California tax amnesty in 1984-85 allowed known delinquents of individual income taxes to participate in the amnesty but it didn't allow known delinquents of sales taxes to participate in the amnesty. 


\section{Table 3.12 - Regression Results for Delinquent Participation on Amnesty}

(Log of per capita total tax revenue as dependent variable)

\begin{tabular}{|c|c|c|c|c|}
\hline Variable & \multicolumn{4}{|c|}{ Delinquent Participation } \\
\hline & Allowed & Not allowed & Allowed & Not allowed \\
\hline & (1) & (2) & (3) & (4) \\
\hline $\begin{array}{l}\text { Short-run effect of } \\
\text { Amnesty1 }\end{array}$ & $\begin{array}{l}.052^{* *} \\
(2.28)\end{array}$ & $\begin{array}{l}.088^{* * *} \\
(3.03)\end{array}$ & $\begin{array}{l}.053^{* *} \\
(2.35)\end{array}$ & $\begin{array}{l}.088^{* \star *} \\
(3.03)\end{array}$ \\
\hline $\begin{array}{l}\text { Short-run effect of } \\
\text { Amnesty2 }\end{array}$ & $\begin{array}{l}-.014 \\
(0.44)\end{array}$ & $\begin{array}{l}-.048 \\
(0.51)\end{array}$ & $\begin{array}{l}-.012 \\
(0.38)\end{array}$ & $\begin{array}{l}-.045 \\
(0.48)\end{array}$ \\
\hline $\begin{array}{l}\text { Short-run effect of } \\
\text { Amnesty3 }\end{array}$ & $\begin{array}{l}-.042 \\
(0.42)\end{array}$ & & $\begin{array}{l}-.053 \\
(0.53)\end{array}$ & \\
\hline $\begin{array}{l}\text { Long-run effect of } \\
\text { Amnesty1 }\end{array}$ & $\begin{array}{l}-.045^{\star \star \star} \\
(4.29)\end{array}$ & $\begin{array}{l}-.033^{* *} \\
(2.43)\end{array}$ & $\begin{array}{c}-.046^{* * *} \\
(4.41)\end{array}$ & $\begin{array}{l}-.034^{* *} \\
(2.49)\end{array}$ \\
\hline $\begin{array}{l}\text { Long-run effect of } \\
\text { Amnesty2 }\end{array}$ & $\begin{array}{l}-.045^{\star \star \star} \\
(2.84)\end{array}$ & $\begin{array}{l}-.147^{\star \star \star} \\
(2.59)\end{array}$ & $\begin{array}{c}-.048^{\star \star \star} \\
(3.01)\end{array}$ & $\begin{array}{l}-.153^{\star \star \star} \\
(2.70)\end{array}$ \\
\hline $\begin{array}{l}\text { Long-run effect of } \\
\text { Amnesty3 }\end{array}$ & $\begin{array}{l}-.027 \\
(0.32)\end{array}$ & & $\begin{array}{l}-.011 \\
(0.13)\end{array}$ & \\
\hline $\begin{array}{l}\text { Log of Per Capita } \\
\text { Personal Income }\end{array}$ & $\begin{array}{c}1.028^{* * *} \\
(11.67)\end{array}$ & $\begin{array}{l}.964^{\star * *} \\
(8.60)\end{array}$ & $\begin{array}{c}1.030^{* * *} \\
(11.71)\end{array}$ & $\begin{array}{l}.959 * \star \star \\
(8.55)\end{array}$ \\
\hline $\begin{array}{l}\text { Log of Personal Income } \\
\text { Tax Rate }\end{array}$ & $\begin{array}{l}-.013 \\
(1.06)\end{array}$ & $\begin{array}{l}-.021 \\
(1.35)\end{array}$ & $\begin{array}{l}-.014 \\
(1.15)\end{array}$ & $\begin{array}{l}-.021 \\
(1.35)\end{array}$ \\
\hline $\begin{array}{l}\text { Log of Corporate } \\
\text { Income Tax Rate }\end{array}$ & $\begin{array}{l}.068^{* *} \\
(2.31)\end{array}$ & $\begin{array}{l}-.049 \\
(1.26)\end{array}$ & $\begin{array}{l}.067^{* *} \\
(2.28)\end{array}$ & $\begin{array}{l}-.053 \\
(1.36)\end{array}$ \\
\hline Log of Sales Tax Rate & $\begin{array}{l}.097^{* \star *} \\
(3.35)\end{array}$ & $\begin{array}{l}.206^{* \star \star} \\
(5.62)\end{array}$ & $\begin{array}{l}.091^{* \star *} \\
(3.15)\end{array}$ & $\begin{array}{l}.206^{* \star *} \\
(5.60)\end{array}$ \\
\hline $\begin{array}{l}\text { Log of unemployment } \\
\text { rate }\end{array}$ & $\begin{array}{l}-.073^{* \star *} \\
(4.78)\end{array}$ & $\begin{array}{l}-.064^{* \star *} \\
(2.81)\end{array}$ & $\begin{array}{l}-.065^{* \star *} \\
(4.12)\end{array}$ & $\begin{array}{l}-.059^{* \star *} \\
(2.57)\end{array}$ \\
\hline $\begin{array}{l}\text { Budget Surplus or } \\
\text { Shortfall as a percent of } \\
\text { Total Tax Revenue }\end{array}$ & & & $\begin{array}{l}.060^{* *} \\
(2.39)\end{array}$ & $\begin{array}{c}.044 \\
(1.58)\end{array}$ \\
\hline Constant & $\begin{array}{c}-3.827^{* * *} \\
(4.31)\end{array}$ & $\begin{array}{c}-3.188^{* * *} \\
(2.81)\end{array}$ & $\begin{array}{c}-3.864^{* * *} \\
(4.36)\end{array}$ & $\begin{array}{l}-3.144 \\
(2.77)\end{array}$ \\
\hline $\mathrm{R}^{2}$ & 0.593 & 0.569 & 0.595 & 0.567 \\
\hline No of Observations & 2052 & 1279 & 2052 & 1279 \\
\hline Model & Fixed Effects & Fixed Effects & Fixed Effects & Fixed Effects \\
\hline
\end{tabular}

Notes: Figures in parenthesis are absolute t-statistics, ${ }^{* * *}$ indicates 1 percent significance level, ${ }^{* *}$ indicates 5 percent significance level, *indicates 10 percent significance level. 


\subsection{Effects of Permitting Installment Payment on State Tax Amnesty}

A third difference across states that is not controlled for in the previous regressions is whether the state permitted installment arrangement to pay back taxes and interests. This also could potentially alter the revenue impact of the amnesty. Table 3.13 provides information on whether states permitted installment arrangement to facilitate the amnesty collection in their amnesties during the 1982-2004 period. In order to assess the effects of permitting installment arrangement, I run separate regressions for each category (i) if installment arrangement was permitted and (ii) if installment arrangement was not permitted; I didn't run a third separate regression for the category if the installment arrangement status was unknown. The regression results are presented in Table 3.14. ${ }^{36}$

The results show that permitting installment arrangement to facilitate the payment of back taxes and interests tend to produce desired effects. States that permitted installment arrangement tend to have a higher positive short-run revenue effect estimate than the states that didn't. Furthermore, states that permitted installment arrangement tend to have a lower negative long-run revenue effect estimate than the states that didn't.

\footnotetext{
${ }^{36}$ Asymptotic assumption for Hausman test was not satisfied for some of the categories of states, therefore, only fixed effects results are reported.
} 


\section{Table 3.13 - Installment Arrangement Information of State Tax Amnesty Program}

(1982-2004)

\begin{tabular}{|l|c|l|}
\hline \multicolumn{1}{|c|}{ Category } & $\begin{array}{c}\text { No of } \\
\text { States }\end{array}$ & \multicolumn{1}{c|}{ State Amnesties } \\
\hline $\begin{array}{l}\text { Installment arrangement } \\
\text { permitted }\end{array}$ & 26 & $\begin{array}{l}\text { Arizona (1982-83 and 2003), Arkansas (1987), California (1984-85), } \\
\text { Colorado (1985 and 2003), Connecticut (1990 and 1995), Louisiana } \\
\text { (1985 and 1987), Maine (1990), Massachusetts (1984 and 2002), New } \\
\text { Mexico (1985 and 1999), New Jersey (1987), New York (1985-86, } \\
\text { 1996-97 and 2002-03), North Dakota (1983), Rhode Island (1986-87 } \\
\text { and 1996), South Carolina (1985), West Virginia (1986 and 2004), } \\
\text { Wisconsin (1985) }\end{array}$ \\
\hline $\begin{array}{l}\text { Installment arrangement } \\
\text { not permitted }\end{array}$ & \multirow{2}{*}{$\begin{array}{l}\text { Wlabama (1984), Arizona (2002), Arkansas (2004), Florida (1987 and } \\
\text { 1988), Georgia (1992), Idaho (1983), Illinois (1984), Kansas (1984), } \\
\text { Kentucky (1988 and 2002), Louisiana (1998 and 2001), Maryland } \\
\text { (1987 and 2001), Michigan (1986), Minnesota (1984), Mississippi } \\
\text { (1986 and 2004), Missouri (1983), Nebraska (2004), New Hampshire } \\
\text { (1997-98), New Jersey (1996), North Carolina (1989), Ohio (2001-02), } \\
\text { Oklahoma (1984), Pennsylvania (1995-96), Texas (1984 and 2004), } \\
\text { Vermont (1990), Virginia (1990), }\end{array}$} \\
\hline $\begin{array}{l}\text { Installment arrangement } \\
\text { permit status unknown }\end{array}$ & 19 & $\begin{array}{l}\text { Connecticut (2002), Florida (2003), Illinois (2003), Iowa (1986), } \\
\text { Kansas (2003), Maine 2003), Massachusetts (2003), Michigan (2002), } \\
\text { Missouri (2002 and 2003), Nevada (2002), New Hampshire (2001-02), } \\
\text { New Jersey (2002), North Dakota (2003-04), Oklahoma (2002), South } \\
\text { Carolina (2002), South Dakota (1999), Virginia (2003), Wisconsin } \\
\text { (1998) }\end{array}$ \\
\hline
\end{tabular}

Source: FTA, January 2005. http://www.taxadmin.org/fta/rate/amnesty1.html (web page access date $5 / 8 / 2005)$. 


\section{Table 3.14 - Regression Results for Permitted Installment Arrangement of Tax Payment on Amnesty}

(Log of per capita total tax revenue as dependent variable)

\begin{tabular}{|c|c|c|c|c|}
\hline \multirow[t]{2}{*}{ Variable } & \multicolumn{4}{|c|}{ Installment Arrangement } \\
\hline & Permitted & Not permitted & Permitted & Not permitted \\
\hline & (1) & (2) & (3) & (4) \\
\hline $\begin{array}{l}\text { Short-run effect of } \\
\text { Amnesty1 }\end{array}$ & $\begin{array}{l}.091^{* * *} \\
(3.22)\end{array}$ & $\begin{array}{l}.067^{* * *} \\
(2.73)\end{array}$ & $\begin{array}{l}.091^{* \star *} \\
(3.23)\end{array}$ & $\begin{array}{l}.068^{* * *} \\
(2.77)\end{array}$ \\
\hline $\begin{array}{l}\text { Short-run effect of } \\
\text { Amnesty2 }\end{array}$ & $\begin{array}{l}.042 \\
(\Theta .9 \odot)\end{array}$ & $\begin{array}{l}-.041 \\
(0.53)\end{array}$ & $\begin{array}{l}.043 \\
(0.93)\end{array}$ & $\begin{array}{l}-.043 \\
(0.55)\end{array}$ \\
\hline $\begin{array}{l}\text { Long-run effect of } \\
\text { Amnesty1 }\end{array}$ & $\begin{array}{l}-.042^{\star \star \star} \\
(3.18)\end{array}$ & $\begin{array}{l}-.054^{\star \star \star} \\
(5.15)\end{array}$ & $\begin{array}{l}-.042^{\star \star \star} \\
(3.20)\end{array}$ & $\begin{array}{l}-.055^{\star \star \star} \\
(5.25)\end{array}$ \\
\hline $\begin{array}{l}\text { Long-run effect of } \\
\text { Amnesty2 }\end{array}$ & $\begin{array}{l}-.039^{* *} \\
(2.25)\end{array}$ & $\begin{array}{l}-.028 \\
(0.56) \\
\end{array}$ & $\begin{array}{l}-.039^{* \star} \\
(2.27)\end{array}$ & $\begin{array}{l}-.300 \\
(0.59) \\
\end{array}$ \\
\hline $\begin{array}{l}\text { Log of Per Capita } \\
\text { Personal Income }\end{array}$ & $\begin{array}{l}.909 * \star * \\
(9.69)\end{array}$ & $\begin{array}{l}.748^{* * *} \\
(7.33)\end{array}$ & $\begin{array}{l}.911^{* * *} \\
(9.71)\end{array}$ & $\begin{array}{l}.747^{* \star *} \\
(7.33)\end{array}$ \\
\hline $\begin{array}{l}\text { Log of Personal Income } \\
\text { Tax Rate }\end{array}$ & $\begin{array}{l}-.034^{\star *} \\
(2.28)\end{array}$ & $\begin{array}{l}-.011 \\
(0.85)\end{array}$ & $\begin{array}{l}-.033^{\star *} \\
(2.20)\end{array}$ & $\begin{array}{l}-.011 \\
(0.89)\end{array}$ \\
\hline $\begin{array}{l}\text { Log of Corporate } \\
\text { Income Tax Rate }\end{array}$ & $\begin{array}{l}-.005 \\
(0.12)\end{array}$ & $\begin{array}{l}.010 \\
(\Theta .31)\end{array}$ & $\begin{array}{l}-.001 \\
(0.03)\end{array}$ & $\begin{array}{l}.007 \\
(0.21)\end{array}$ \\
\hline Log of Sales Tax Rate & $\begin{array}{l}.087^{* * *} \\
(2.09)\end{array}$ & $\begin{array}{l}.221^{* \star *} \\
(6.72)\end{array}$ & $\begin{array}{l}.083^{* *} \\
(2.00)\end{array}$ & $\begin{array}{l}.216^{* * *} \\
(6.56)\end{array}$ \\
\hline $\begin{array}{l}\text { Log of unemployment } \\
\text { rate }\end{array}$ & $\begin{array}{l}-.083^{* * *} \\
(4.84)\end{array}$ & $\begin{aligned}-.058^{* * *} & (3.03)\end{aligned}$ & $\begin{array}{l}-.076^{* * *} \\
(4.31)\end{array}$ & $\begin{array}{l}-.055^{* * *} \\
(2.82)\end{array}$ \\
\hline $\begin{array}{l}\text { Budget Surplus or } \\
\text { Shortfall as a percent of } \\
\text { Total Tax Revenue }\end{array}$ & & & $\begin{array}{l}.037 \\
(1.41)\end{array}$ & $\begin{array}{l}.043 \\
(1.49)\end{array}$ \\
\hline Constant & $\begin{array}{c}-2.819^{* * *} \\
(3.02)\end{array}$ & $\begin{array}{c}-.756 \\
(0.71)\end{array}$ & $\begin{array}{c}-2.841^{* * *} \\
(3.04)\end{array}$ & $\begin{array}{c}-. .762 \\
(0.72)\end{array}$ \\
\hline $\mathrm{R}^{2}$ & 0.527 & 0.605 & 0.529 & 0.605 \\
\hline No of Observations & 1273 & 1647 & 1273 & 1647 \\
\hline Model & Fixed Effects & Fixed Effects & Fixed Effects & Fixed Effects \\
\hline
\end{tabular}

Notes: Figures in parenthesis are absolute t-statistics, ***indicates 1 percent significance level, **indicates 5 percent significance level, *indicates 10 percent significance level. 


\subsection{Empirical Analysis and Results: Specific Tax Revenue}

While most amnesties are broad based, covering simultaneously most major state taxes, this does not necessarily imply that each revenue source is impacted similarly. In this section I turn to performing analysis separately for each of the three largest state tax revenue sources: the sales tax, personal income tax, and corporate income tax. Like total tax revenue, I estimate the model on subsets of the data based on the number of amnesties offered by the state. I estimate the regression only among states with zero or one amnesty, then reestimate it expanding the sample to states with two amnesties, then again to states with three amnesties. The results are discussed below.

\subsubsection{Results for Per Capita Sales Tax Revenue}

The fixed effects results for per capita sales tax revenue are shown in Tables 3.15a and 3.15b. The Hausman test statistics, presented in the bottom row of the tables, allows us to use random effects model but as there is no significant gain using the random effects model, I use the fixed effects models. However, alternative estimates from the random effects models are also presented in Appendix XIIa and Appendix XIIb.

Table 3.15a presents the result of the fixed effects estimations on the specification excluding the budget shortfall variable, while Table 3.15b shows the results with this variable included and it makes only a small difference in the main coefficients of interest. Comparing the first three columns in Tables 3.15a and 3.15b, the results are not as robust as per capita total tax revenue to whether I include or exclude the states that have offered multiple amnesties. Focusing on the final two columns, where I control for the time 
elapsed between cases of multiple amnesties, unlike other taxes these variables are always insignificant.

The short-run coefficient estimates for amnesty 1 are always positive and most often significant at ten percent level. This can be interpreted to suggest that there is some evidence states might see about 4 percent increase in real per capita sales tax revenue during the period of the amnesty. However, the long run coefficient estimates for amnesty 1 are always negative and significant except for states with three amnesties. The results for the short run effects of the second amnesty (amnesty 2) are always negative but never significant. However, the results for the long run effects of the second amnesty (amnesty 2) are always positive and three out of four times significant. This can be interpreted to suggest that although the second amnesty does not produce short run sales tax revenue but long run effect is also not compromised. Finally, when a state offers a third amnesty, again there is no significant short run revenue produced, and but the long run revenue gain or loss is also not significant. The results for sales tax revenue are quite different than the other taxes. 


\section{Table 3.15a - Regression Results for Per Capita Sales Tax Revenue}

(Log of per capita sales tax revenue as dependent variable and without budget surplus and shortfall variable)

\begin{tabular}{|c|c|c|c|c|c|}
\hline Variable & $\begin{array}{l}\text { States with one } \\
\text { Amnesty }\end{array}$ & $\begin{array}{c}\text { States with one } \\
\text { \& two } \\
\text { Amnesties }\end{array}$ & $\begin{array}{l}\text { States with one, } \\
\text { two, \& three } \\
\text { Amnesties }\end{array}$ & $\begin{array}{c}\text { States with one } \\
\text { \& two } \\
\text { Amnesties }\end{array}$ & $\begin{array}{l}\text { States with one, } \\
\text { two, \& three } \\
\text { Amnesties }\end{array}$ \\
\hline & (1) & $(2)$ & (3) & (4) & (5) \\
\hline $\begin{array}{l}\text { Short-run effect of } \\
\text { Amnesty1 }\end{array}$ & $\begin{array}{l}.058 \\
(1.57)\end{array}$ & $\begin{array}{l}.050^{*} \\
(1.91)\end{array}$ & $\begin{array}{l}.041^{*} \\
(1.86)\end{array}$ & $\begin{array}{l}.050^{*} \\
(1.91)\end{array}$ & $\begin{array}{l}.042^{*} \\
(1.88)\end{array}$ \\
\hline $\begin{array}{l}\text { Short-run effect of } \\
\text { Amnesty2 }\end{array}$ & & $\begin{array}{l}-.063 \\
(1.27)\end{array}$ & $\begin{array}{l}-.039 \\
(1.08)\end{array}$ & $\begin{array}{l}-.048 \\
(0.49)\end{array}$ & $\begin{array}{c}-.032 \\
(0.42)\end{array}$ \\
\hline $\begin{array}{l}\text { Short-run effect of } \\
\text { Amnesty3 }\end{array}$ & & & $\begin{array}{l}-.127 \\
(1.56)\end{array}$ & & $\begin{array}{l}-.123 \\
(1.51)\end{array}$ \\
\hline $\begin{array}{l}\text { Long-run effect of } \\
\text { Amnesty1 }\end{array}$ & $\begin{array}{l}-.050^{* * *} \\
(3.41)\end{array}$ & $\begin{array}{l}-.025^{\star *} \\
(2.23)\end{array}$ & $\begin{array}{l}-.013 \\
(1.31)\end{array}$ & $\begin{array}{l}-.025^{\star \star} \\
(2.25)\end{array}$ & $\begin{array}{l}-.014 \\
(1.41)\end{array}$ \\
\hline $\begin{array}{l}\text { Long-run effect of } \\
\text { Amnesty2 }\end{array}$ & & $\begin{array}{l}.039^{\star} \\
(1.91)\end{array}$ & $\begin{array}{l}.031^{\star *} \\
(2.02)\end{array}$ & $\begin{array}{l}.054 \\
(1.27)\end{array}$ & $\begin{array}{l}.065^{\star} \\
(1.93)\end{array}$ \\
\hline $\begin{array}{l}\text { Long-run effect of } \\
\text { Amnesty3 }\end{array}$ & & & $\begin{array}{l}.008 \\
(0.19)\end{array}$ & & $\begin{array}{l}-.003 \\
(0.06)\end{array}$ \\
\hline $\begin{array}{l}\text { Time difference } \\
\text { between } 1^{\text {st }} \& 2^{\text {nd }} \\
\text { Amnesty (Short Run } \\
\text { Effect) }\end{array}$ & & & & $\begin{array}{l}-.0007 \\
(0.10)\end{array}$ & $\begin{array}{l}.0006 \\
(0.11)\end{array}$ \\
\hline $\begin{array}{l}\text { Time difference } \\
\text { between } 1^{\text {st }} \& 2^{\text {nd }} \\
\text { Amnesty (Long Run } \\
\text { Effect) }\end{array}$ & & & & $\begin{array}{c}-.002 \\
(0.38)\end{array}$ & $\begin{array}{l}-.004 \\
(1.13)\end{array}$ \\
\hline $\begin{array}{l}\text { Log of Per Capita } \\
\text { Personal Income }\end{array}$ & $\begin{array}{c}1.505^{* * *} \\
(12.61)\end{array}$ & $\begin{array}{c}1.222 * * * \\
(12.86)\end{array}$ & $\begin{array}{c}1.370^{* * *} \\
(16.55)\end{array}$ & $\begin{array}{c}1.225^{* * *} \\
(12.84)\end{array}$ & $\begin{array}{c}1.373^{* \star *} \\
(16.58)\end{array}$ \\
\hline Log of Sales Tax Rate & $\begin{array}{l}.431^{* * *} \\
(10.30)\end{array}$ & $\begin{array}{l}.503^{* \star *} \\
(16.53)\end{array}$ & $\begin{array}{l}.499 * \star * \\
(18.26)\end{array}$ & $\begin{array}{l}.504^{\star \star *} \\
(16.53)\end{array}$ & $\begin{array}{l}.502^{* * *} \\
(18.29)\end{array}$ \\
\hline $\begin{array}{l}\text { Log of unemployment } \\
\text { rate }\end{array}$ & $\begin{array}{l}-.029 \\
(1.09)\end{array}$ & $\begin{array}{l}-.075^{* * *} \\
(3.87)\end{array}$ & $\begin{array}{l}-.065^{* * *} \\
(3.96)\end{array}$ & $\begin{array}{l}-.075^{\star * *} \\
(3.86)\end{array}$ & $\begin{array}{c}-.065^{* * *} \\
(3.93)\end{array}$ \\
\hline Constant & $\begin{array}{c}-8.935^{\star \star *} \\
(7.24)\end{array}$ & $\begin{array}{c}-5.840^{* \star *} \\
(6.06)\end{array}$ & $\begin{array}{c}7.423^{* * *} \\
(8.89)\end{array}$ & $\begin{array}{c}-5.873^{\star \star \star} \\
(6.07)\end{array}$ & $\begin{array}{c}-7.452^{\star \star \star} \\
(8.92)\end{array}$ \\
\hline $\mathrm{R}^{2}$ & 0.361 & 0.260 & 0.233 & 0.260 & 0.233 \\
\hline No of Observations & 2083 & 3351 & 3897 & 3351 & 3897 \\
\hline $\begin{array}{l}\text { Model Suggested by } \\
\text { Hausman Test }\end{array}$ & Fixed Effects & Fixed Effects & Fixed Effects & Fixed Effects & Fixed Effects \\
\hline$\chi^{2}$ value & $\chi^{2}(92)=5.20$ & $\chi^{2}(94)=18.30$ & $\chi^{2}(96)=42.29$ & $\chi^{2}(96)=16.70$ & $\chi^{2}(98)=6.02$ \\
\hline
\end{tabular}

Notes: Figures in parenthesis are absolute t-statistics, ${ }^{* * *}$ indicates 1 percent significance level, ${ }^{* *}$ indicates 5 percent significance level, *indicates 10 percent significance level. 
Table 3.15b - Regression Results for Per Capita Sales Tax Revenue

(Log of per capita sales tax revenue as dependent variable and with budget surplus and shortfall variable)

\begin{tabular}{|c|c|c|c|c|c|}
\hline Variable & $\begin{array}{l}\text { States with one } \\
\text { Amnesty }\end{array}$ & $\begin{array}{c}\text { States with one } \\
\text { \& two } \\
\text { Amnesties }\end{array}$ & $\begin{array}{l}\text { States with one, } \\
\text { two, \& three } \\
\text { Amnesties }\end{array}$ & $\begin{array}{c}\text { States with one } \\
\text { \& two } \\
\text { Amnesties }\end{array}$ & $\begin{array}{l}\text { States with one, } \\
\text { two, \& three } \\
\text { Amnesties }\end{array}$ \\
\hline & (1) & (2) & (3) & (4) & (5) \\
\hline $\begin{array}{l}\text { Short-run effect of } \\
\text { Amnesty1 }\end{array}$ & $\begin{array}{l}.056 \\
(1.51) \\
\end{array}$ & $\begin{array}{l}.049^{*} \\
(1.90) \\
\end{array}$ & $\begin{array}{l}.041^{*} \\
(1.84)\end{array}$ & $\begin{array}{l}.049^{*} \\
(1.90)\end{array}$ & $\begin{array}{l}.041^{\star} \\
(1.85)\end{array}$ \\
\hline $\begin{array}{l}\text { Short-run effect of } \\
\text { Amnesty2 }\end{array}$ & & $\begin{array}{l}-.060 \\
(1.21)\end{array}$ & $\begin{array}{l}-.037 \\
(1.05)\end{array}$ & $\begin{array}{l}-.053 \\
(0.54)\end{array}$ & $\begin{array}{l}-.034 \\
(0.45)\end{array}$ \\
\hline $\begin{array}{l}\text { Short-run effect of } \\
\text { Amnesty3 }\end{array}$ & & & $\begin{array}{l}-.121 \\
(1.48)\end{array}$ & & $\begin{array}{l}-.118 \\
(1.44)\end{array}$ \\
\hline $\begin{array}{l}\text { Long-run effect of } \\
\text { Amnesty1 }\end{array}$ & $\begin{array}{c}-.049^{* * *} \\
(3.35)\end{array}$ & $\begin{array}{l}-.025^{\star *} \\
(2.21)\end{array}$ & $\begin{array}{l}-.013 \\
(1.27)\end{array}$ & $\begin{array}{l}-.025^{* *} \\
(2.22)\end{array}$ & $\begin{array}{l}-.014 \\
(1.36)\end{array}$ \\
\hline $\begin{array}{l}\text { Long-run effect of } \\
\text { Amnesty2 }\end{array}$ & & $\begin{array}{l}.040^{\star} \\
(1.91)\end{array}$ & $\begin{array}{l}.031^{* *} \\
(1.97)\end{array}$ & $\begin{array}{l}.048 \\
(1.14)\end{array}$ & $\begin{array}{l}.062^{\star} \\
(1.85)\end{array}$ \\
\hline $\begin{array}{l}\text { Long-run effect of } \\
\text { Amnesty3 }\end{array}$ & & & $\begin{array}{c}.002 \\
(0.05)\end{array}$ & & $\begin{array}{l}-.008 \\
(0.18)\end{array}$ \\
\hline $\begin{array}{l}\text { Time difference } \\
\text { between } 1^{\text {st }} \& 2^{\text {nd }} \\
\text { Amnesty (Short Run } \\
\text { Effect) }\end{array}$ & & & & $\begin{array}{l}-.0002 \\
(0.03)\end{array}$ & $\begin{array}{l}.001 \\
(0.14)\end{array}$ \\
\hline $\begin{array}{l}\text { Time difference } \\
\text { between } 1^{\text {st }} \& 2^{\text {nd }} \\
\text { Amnesty (Long Run } \\
\text { Effect) }\end{array}$ & & & & $\begin{array}{l}-.001 \\
(\odot .23)\end{array}$ & $\begin{array}{l}-.003 \\
(1.07)\end{array}$ \\
\hline $\begin{array}{l}\text { Log of Per Capita } \\
\text { Personal Income }\end{array}$ & $\begin{array}{c}1.496 * * * \\
(12.54)\end{array}$ & $\begin{array}{c}1.220^{* * *} \\
(12.85)\end{array}$ & $\begin{array}{c}1.370^{* * *} \\
(16.56)\end{array}$ & $\begin{array}{l}1.222^{* *} \\
(12.82)\end{array}$ & $\begin{array}{c}1.374 * * * \\
(16.58)\end{array}$ \\
\hline Log of Sales Tax Rate & $\begin{array}{l}.423^{* * *} \\
(10.05)\end{array}$ & $\begin{array}{l}.501^{* \star *} \\
(16.43)\end{array}$ & $\begin{array}{l}.497^{\star \star *} \\
(18.14)\end{array}$ & $\begin{array}{l}.501^{* * *} \\
(16.42)\end{array}$ & $\begin{array}{l}.499 * * * \\
(18.17)\end{array}$ \\
\hline $\begin{array}{l}\text { Log of unemployment } \\
\text { rate }\end{array}$ & $\begin{array}{l}-.025 \\
(0.93)\end{array}$ & $\begin{array}{c}-.070^{* * *} \\
(3.58)\end{array}$ & $\begin{array}{c}-.061^{* * *} \\
(3.64)\end{array}$ & $\begin{array}{l}-.700^{* * *} \\
(3.57)\end{array}$ & $\begin{aligned}-.060^{* * *} \\
(3.62)\end{aligned}$ \\
\hline $\begin{array}{l}\text { Budget Surplus or } \\
\text { Shortfall as a percent } \\
\text { of Total Tax Revenue }\end{array}$ & $\begin{array}{l}.048^{\star \star} \\
(1.99)\end{array}$ & $\begin{array}{l}.041^{* *} \\
(2.12)\end{array}$ & $\begin{array}{l}.035^{* *} \\
(1.97)\end{array}$ & $\begin{array}{l}.041^{* *} \\
(2.10)\end{array}$ & $\begin{array}{l}.035^{\star} \\
(1.94)\end{array}$ \\
\hline Constant & $\begin{array}{c}-8.868^{* \star \star} \\
(7.19)\end{array}$ & $\begin{array}{l}-5.828^{* * *} \\
(6.05)\end{array}$ & $\begin{array}{c}-7.433^{* * *} \\
(8.90)\end{array}$ & $\begin{array}{l}-5.848^{\star \star *} \\
(6.04)\end{array}$ & $\begin{array}{c}-7.460^{* * *} \\
(8.93)\end{array}$ \\
\hline $\mathrm{R}^{2}$ & 0.361 & 0.262 & 0.234 & 0.261 & 0.234 \\
\hline No of Observations & 2083 & 3351 & 3897 & 3351 & 3897 \\
\hline $\begin{array}{l}\text { Model Suggested by } \\
\text { Hausman Test }\end{array}$ & Fixed Effects & Fixed Effects & Fixed Effects & Fixed Effects & Fixed Effects \\
\hline$\chi^{2}$ value & $\chi^{2}(93)=3.91$ & $\chi^{2}(95)=14.78$ & $\chi^{2}(97)=93.24$ & $\chi^{2}(97)=12.75$ & $\chi^{2}(99)=36.87$ \\
\hline
\end{tabular}

Notes: Figures in parenthesis are absolute t-statistics, $* * *$ indicates 1 percent significance level, $* *$ indicates 5 percent significance level, *indicates 10 percent significance level. 


\subsubsection{Results for Personal Income Tax Revenue}

Like total tax revenue and sales tax revenue, for personal income tax revenue too, I repeat the estimation process on subsets of the data based on the number of amnesties offered by the state. I estimate the regression only among states with zero or one amnesty, then reestimate it expanding the sample to states with two amnesties, then again to states with three amnesties. Because heteroskedasticity problem was detected with the personal income tax revenue data, I do not run fixed or random effects model. ${ }^{37}$ Instead, I run panel corrected standard error GLS model, which takes into account the heteroskedasticity in the data. The regression results are presented in Table 3.16a and Table 3.16b.

Table 3.16a presents the result of the panel corrected standard error GLS model excluding the budget shortfall variable, while Table 3.16b shows the results with this variable included and the inclusion or exclusion of this variable makes only a small difference in the main coefficients of interest. Comparing the first three columns in Tables 3.16a and 3.16b, my results are robust to whether I include or exclude the states that have offered multiple amnesties. Focusing on the final two columns, where I control for the time elapsed between cases of multiple amnesties, unlike total tax and sales tax revenues the long run effect of the time difference between first and second amnesty are always positive and significant. This implies that for personal income tax, the long run effect of a successive amnesty is less harmful given a longer time lag.

\footnotetext{
${ }^{37}$ Heteroskedasticity results are reported in the Appendix X.
} 
The short-run coefficient estimates for amnesty 1 are always positive but insignificant. This can be interpreted to suggest that states might see only a small (insignificant) increase in revenue from personal income tax during the period of amnesty. However, the long-run coefficient estimates for amnesty 1 are always negative and significant. This can be interpreted to suggest that the small (insignificant) increase in revenue from personal income tax during the period of amnesty is followed by a significant and larger negative effect on long run revenue. Since the true first period impact of the amnesty would include both the short run inflow of short run revenue and the long run revenue loss combined, after the first period, only the long-run impact remains. The short and long-run effects of the second amnesty (amnesty 2), as anticipated, does not produce as much short run revenue but does produce a significant and negative long run effect that is greater than the negative long run effect for the first amnesty. Finally, when a state offers a third amnesty, again there is no significant short run revenue produced from the personal income tax, but also the long run revenue gain or loss is not significant. 


\section{Table 3.16a - Regression Results with Panel Corrected Standard Errors for Per Capita Personal Income Tax Revenue}

(Log of per capita personal income tax revenue as dependent variable and without budget surplus and shortfall variable)

\begin{tabular}{|c|c|c|c|c|c|}
\hline Variable & $\begin{array}{c}\text { States with one } \\
\text { Amnesty }\end{array}$ & $\begin{array}{c}\text { States with one } \\
\text { \& two } \\
\text { Amnesties }\end{array}$ & $\begin{array}{l}\text { States with one, } \\
\text { two, \& three } \\
\text { Amnesties }\end{array}$ & $\begin{array}{c}\text { States with one } \\
\text { \& two } \\
\text { Amnesties }\end{array}$ & $\begin{array}{l}\text { States with one, } \\
\text { two, \& three } \\
\text { Amnesties }\end{array}$ \\
\hline & (1) & (2) & (3) & (4) & (5) \\
\hline $\begin{array}{l}\text { Short-run effect of } \\
\text { Amnesty1 }\end{array}$ & $\begin{array}{c}.038 \\
(0.57)\end{array}$ & $\begin{array}{c}.018 \\
(0.32)\end{array}$ & $\begin{array}{l}.037 \\
(0.98)\end{array}$ & $\begin{array}{l}.019 \\
(0.34)\end{array}$ & $\begin{array}{l}.037 \\
(1.00)\end{array}$ \\
\hline $\begin{array}{l}\text { Short-run effect of } \\
\text { Amnesty2 }\end{array}$ & & $\begin{array}{l}.183 \\
(1.30) \\
\end{array}$ & $\begin{array}{l}.104 \\
(1.21) \\
\end{array}$ & $\begin{array}{c}.044 \\
(0.21) \\
\end{array}$ & $\begin{array}{l}.110 \\
(0.59)\end{array}$ \\
\hline $\begin{array}{l}\text { Short-run effect of } \\
\text { Amnesty3 }\end{array}$ & & & $\begin{array}{c}.017 \\
(0.07)\end{array}$ & & $\begin{array}{l}-.079 \\
(0.32)\end{array}$ \\
\hline $\begin{array}{l}\text { Long-run effect of } \\
\text { Amnesty1 }\end{array}$ & $\begin{array}{l}-.053^{* * *} \\
(5.04)\end{array}$ & $\begin{array}{l}-.137^{* * *} \\
(12.44)\end{array}$ & $\begin{array}{l}-.139^{* * *} \\
(17.04)\end{array}$ & $\begin{array}{l}-.138^{* * *} \\
(12.37)\end{array}$ & $\begin{array}{l}-.139^{* * *} \\
(16.52)\end{array}$ \\
\hline $\begin{array}{l}\text { Long-run effect of } \\
\text { Amnesty2 }\end{array}$ & & $\begin{aligned}- & .257^{* * *} \\
& (4.64)\end{aligned}$ & $\begin{aligned}- & .225^{* * *} \\
& (6.50)\end{aligned}$ & $\begin{array}{l}-.495^{* * *} \\
(5.65)\end{array}$ & $\begin{array}{l}-.461^{* \star *} \\
(7.99)\end{array}$ \\
\hline $\begin{array}{l}\text { Long-run effect of } \\
\text { Amnesty3 }\end{array}$ & & & $\begin{array}{l}-.097^{*} \\
(1.91)\end{array}$ & & $\begin{array}{l}.071 \\
(1.29)\end{array}$ \\
\hline $\begin{array}{l}\text { Time difference } \\
\text { between } 1^{\text {st }} \& 2^{\text {nd }} \\
\text { Amnesty (Short Run } \\
\text { Effect) }\end{array}$ & & & & $\begin{array}{l}-.007 \\
(0.43)\end{array}$ & $\begin{array}{l}-.013 \\
(1.12)\end{array}$ \\
\hline $\begin{array}{l}\text { Time difference } \\
\text { between } 1^{\text {st }} \& 2^{\text {nd }} \\
\text { Amnesty (Long Run } \\
\text { Effect) }\end{array}$ & & & & $\begin{array}{l}.034^{* * *} \\
(4.27)\end{array}$ & $\begin{array}{l}.300^{* \star *} \\
(6.05)\end{array}$ \\
\hline $\begin{array}{l}\text { Log of Per Capita } \\
\text { Personal Income }\end{array}$ & $\begin{array}{c}2.036^{* * *} \\
(38.80)\end{array}$ & $\begin{array}{c}1.857^{* * *} \\
(34.10)\end{array}$ & $\begin{array}{c}1.855^{* * *} \\
(43.27)\end{array}$ & $\begin{array}{c}1.832^{* * *} \\
(33.95)\end{array}$ & $\begin{array}{c}1.845^{* * *} \\
(41.93)\end{array}$ \\
\hline $\begin{array}{l}\text { Log of Personal } \\
\text { Income Tax Rate }\end{array}$ & $\begin{array}{l}.228^{* * *} \\
(20.37)\end{array}$ & $\begin{array}{l}.187^{\star \star \star} \\
(21.86)\end{array}$ & $\begin{array}{l}.231^{* * *} \\
(30.03)\end{array}$ & $\begin{array}{l}.180^{* * *} \\
(21.05)\end{array}$ & $\begin{array}{l}.226^{* \star *} \\
(28.83)\end{array}$ \\
\hline $\begin{array}{l}\text { Log of unemployment } \\
\text { rate }\end{array}$ & $\begin{array}{c}-.064^{* * *} \\
(2.50)\end{array}$ & $\begin{array}{l}.063^{* * *} \\
(2.65)\end{array}$ & $\begin{array}{l}.064^{* * *} \\
(3.86)\end{array}$ & $\begin{array}{l}.069^{* \star *} \\
(2.96)\end{array}$ & $\begin{array}{l}.065^{\star * *} \\
(4.07)\end{array}$ \\
\hline Constant & $\begin{array}{c}-14.838^{* * *} \\
(27.32)\end{array}$ & $\begin{array}{c}-13.297^{* \star *} \\
(23.87)\end{array}$ & $\begin{array}{c}-13.144^{* * *} \\
(29.13)\end{array}$ & $\begin{array}{c}-13.107^{* * *} \\
(23.65)\end{array}$ & $\begin{array}{c}-13.088^{* \star \star} \\
(28.48)\end{array}$ \\
\hline $\mathrm{R}^{2}$ & 0.641 & 0.563 & 0.576 & 0.567 & 0.579 \\
\hline No of Observations & 1919 & 3181 & 3682 & 3181 & 3682 \\
\hline
\end{tabular}

Notes: Figures in parenthesis are absolute z-statistics, ${ }^{* * *}$ indicates 1 percent significance level, ${ }^{* *}$ indicates

5 percent significance level, *indicates 10 percent significance level. 


\section{Table 3.16b - Regression Results with Panel Corrected Standard Errors for Per Capita Personal Income Tax Revenue}

(Log of per capita personal income tax revenue as dependent variable and with budget surplus and shortfall variable)

\begin{tabular}{|c|c|c|c|c|c|}
\hline Variable & $\begin{array}{l}\text { States with one } \\
\text { Amnesty }\end{array}$ & $\begin{array}{c}\text { States with one } \\
\text { \& two } \\
\text { Amnesties }\end{array}$ & $\begin{array}{l}\text { States with one, } \\
\text { two, \& three } \\
\text { Amnesties }\end{array}$ & $\begin{array}{c}\text { States with one } \\
\text { \& two } \\
\text { Amnesties }\end{array}$ & $\begin{array}{c}\text { States with one, } \\
\text { two, \& three } \\
\text { Amnesties }\end{array}$ \\
\hline & (1) & (2) & (3) & (4) & (5) \\
\hline $\begin{array}{l}\text { Short-run effect of } \\
\text { Amnesty1 }\end{array}$ & $\begin{array}{l}.017 \\
(0.27)\end{array}$ & $\begin{array}{c}.014 \\
(0.24)\end{array}$ & $\begin{array}{l}.300 \\
(0.79)\end{array}$ & $\begin{array}{l}.014 \\
(0.26)\end{array}$ & $\begin{array}{l}.030 \\
(0.82)\end{array}$ \\
\hline $\begin{array}{l}\text { Short-run effect of } \\
\text { Amnesty2 }\end{array}$ & & $\begin{array}{l}.196 \\
(1.38)\end{array}$ & $\begin{array}{l}.109 \\
(1.29)\end{array}$ & $\begin{array}{c}.037 \\
(0.17)\end{array}$ & $\begin{array}{l}.104 \\
(0.56)\end{array}$ \\
\hline $\begin{array}{l}\text { Short-run effect of } \\
\text { Amnesty3 }\end{array}$ & & & $\begin{array}{c}.057 \\
(\odot .24)\end{array}$ & & $\begin{array}{l}-.033 \\
(0.14)\end{array}$ \\
\hline $\begin{array}{l}\text { Long-run effect of } \\
\text { Amnesty1 }\end{array}$ & $\begin{array}{l}-.021^{\star} \\
(1.71)\end{array}$ & $\begin{array}{l}-.128^{\star \star \star} \\
(11.74)\end{array}$ & $\begin{array}{c}-.129 * * * \\
(15.41)\end{array}$ & $\begin{array}{c}-.129^{* * *} \\
(11.76)\end{array}$ & $\begin{array}{c}-.129^{* * *} \\
(15.22)\end{array}$ \\
\hline $\begin{array}{l}\text { Long-run effect of } \\
\text { Amnesty2 }\end{array}$ & & $\begin{array}{l}-.259 * \star \star \\
(4.71)\end{array}$ & $\begin{aligned}-.226^{\star \star \star} \\
(6.71)\end{aligned}$ & $\begin{array}{c}-.488^{* \star *} \\
(5.77)\end{array}$ & $\begin{array}{l}-.441^{\star \star \star} \\
(7.79)\end{array}$ \\
\hline $\begin{array}{l}\text { Long-run effect of } \\
\text { Amnesty3 }\end{array}$ & & & $\begin{array}{l}-.120^{\star \star} \\
(2.53)\end{array}$ & & $\begin{array}{l}.033 \\
(0.62)\end{array}$ \\
\hline $\begin{array}{l}\text { Time difference } \\
\text { between } 1^{\text {st }} \& 2^{\text {nd }} \\
\text { Amnesty (Short Run } \\
\text { Effect) }\end{array}$ & & & & $\begin{array}{l}-.005 \\
(0.28)\end{array}$ & $\begin{array}{c}-.011 \\
(0.96)\end{array}$ \\
\hline $\begin{array}{l}\text { Time difference } \\
\text { between } 1^{\text {st }} \& 2^{\text {nd }} \\
\text { Amnesty (Long Run } \\
\text { Effect) }\end{array}$ & & & & $\begin{array}{l}.033^{* \star *} \\
(4.19)\end{array}$ & $\begin{array}{l}.027^{\star \star *} \\
(5.50)\end{array}$ \\
\hline $\begin{array}{l}\text { Log of Per Capita } \\
\text { Personal Income }\end{array}$ & $\begin{array}{c}1.968 * \star \star \\
(38.48)\end{array}$ & $\begin{array}{c}1.850^{\star \star \star} \\
(33.59)\end{array}$ & $\begin{array}{c}1.872^{\star \star \star} \\
(44.65)\end{array}$ & $\begin{array}{c}1.827^{\star \star \star} \\
(33.49)\end{array}$ & $\begin{array}{c}1.861^{\star \star \star} \\
(43.35)\end{array}$ \\
\hline $\begin{array}{l}\text { Log of Personal } \\
\text { Income Tax Rate }\end{array}$ & $\begin{array}{l}.228^{* * *} \\
(22.09)\end{array}$ & $\begin{array}{l}.189^{* \star *} \\
(22.43)\end{array}$ & $\begin{array}{l}.232^{\star \star *} \\
(29.64)\end{array}$ & $\begin{array}{l}.182^{\star * *} \\
(21.48)\end{array}$ & $\begin{array}{l}.227^{\star \star *} \\
(28.7 \odot)\end{array}$ \\
\hline $\begin{array}{l}\text { Log of unemployment } \\
\text { rate }\end{array}$ & $\begin{array}{c}-.083^{* * *} \\
(3.29)\end{array}$ & $\begin{array}{l}.072^{* * *} \\
(3.09)\end{array}$ & $\begin{array}{l}.074^{* * *} \\
(4.7 \odot)\end{array}$ & $\begin{array}{l}.078^{* * *} \\
(3.39)\end{array}$ & $\begin{array}{l}.075^{\star \star *} \\
(4.88)\end{array}$ \\
\hline $\begin{array}{l}\text { Budget Surplus or } \\
\text { Shortfall as a percent } \\
\text { of Total Tax Revenue }\end{array}$ & $\begin{array}{l}.590^{\star \star \star} \\
(9.82)\end{array}$ & $\begin{array}{l}.236^{\star \star \star} \\
(4.93)\end{array}$ & $\begin{array}{l}.232^{\star \star \star} \\
(6.40)\end{array}$ & $\begin{array}{l}.228^{\star \star \star} \\
(5.01)\end{array}$ & $\begin{array}{l}.215^{\star \star \star} \\
(6.24)\end{array}$ \\
\hline Constant & $\begin{array}{c}-14.010^{* * *} \\
(26.49)\end{array}$ & $\begin{array}{c}-13.189^{* * *} \\
(23.38)\end{array}$ & $\begin{array}{c}-13.287^{* * *} \\
(30.06)\end{array}$ & $\begin{array}{c}-13.010^{* * *} \\
(23.22)\end{array}$ & $\begin{array}{c}-13.226^{* * *} \\
(29.44)\end{array}$ \\
\hline $\mathrm{R}^{2}$ & 0.665 & 0.567 & 0.580 & 0.571 & 0.583 \\
\hline No of Observations & 1919 & 3181 & 3682 & 3181 & 3682 \\
\hline
\end{tabular}

Notes: Figures in parenthesis are absolute z-statistics, ${ }^{* * *}$ indicates 1 percent significance level, **indicates 5 percent significance level, *indicates 10 percent significance level. 


\subsubsection{Results for Corporate Income Tax}

Like previous analysis, for corporate income tax, I estimate the model on subsets of the data based on the number of amnesties offered by the state. I estimate the regression only among states with zero or one amnesty, then reestimate it expanding the sample to states with two amnesties, then again to states with three amnesties. The results of the fixed effects estimations are shown in Tables 3.17a and 3.17b. The Hausman test statistics, presented in the bottom row of the tables, allows us to use random effects model but as there is no significant gain using the random effects models, I use the fixed effects models. The alternative estimates from the random effects models are also presented in Appendix XIIIa and Appendix XIIIb.

Table 3.17a presents the result of the fixed effects estimations on the specification excluding the budget shortfall variable, while Table 3.17b shows the results with this variable included and it makes only a small difference in the main coefficients of interest. Comparing the first three columns in Tables 3.17a and 3.17b, my results are robust to whether I include or exclude the states that have offered multiple amnesties. Focusing on the final two columns, where I control for the time elapsed between cases of multiple amnesties, like personal income tax revenue the long run effect of the time difference between first and second amnesty are always positive and significant. This implies that for corporate income tax too, the long run effect of a successive amnesty is less harmful given a longer time lag.

The significant, positive short-run coefficient estimate for amnesty 1 can be interpreted to suggest that the average impact of offering the first amnesty in a state is 
about 14.1 percent increase in real per capita tax revenue during the period of the amnesty due to the increased collections of previous evaders. The significant, negative long-run coefficient estimate for amnesty 1 can be interpreted to suggest that the long-run impact of offering this first tax amnesty is significantly negative on revenue, resulting in about a 9.5 percent ongoing loss each period after the amnesty due to reduced compliance. Since true first period impact of the amnesty would include both the shortrun inflow of short-run revenue and the long-run revenue loss combined, after the first period, only the long-run impact remains. The second amnesty does not produce as much short-run revenue, but does produce a significant and negative long-run effect that is greater than the negative long-run effect for the first amnesty. Finally, when a state offers a third amnesty, again there is no significant short-run revenue produced, and again the negative long-run revenue loss is significant, and larger than it was for the second and first amnesties. 


\section{Table 3.17a - Regression Results for Per Capita Corporate Income Tax Revenue}

(Log of per capita corporate income tax revenue as dependent variable and without budget surplus or shortfall variable)

\begin{tabular}{|c|c|c|c|c|c|}
\hline Variable & $\begin{array}{l}\text { States with one } \\
\text { Amnesty }\end{array}$ & $\begin{array}{c}\text { States with one } \\
\text { \& two } \\
\text { Amnesties } \\
\end{array}$ & $\begin{array}{c}\text { States with one, } \\
\text { two, \& three } \\
\text { Amnesties } \\
\end{array}$ & $\begin{array}{c}\text { States with one } \\
\text { \& two } \\
\text { Amnesties } \\
\end{array}$ & $\begin{array}{c}\text { States with one, } \\
\text { two, \& three } \\
\text { Amnesties } \\
\end{array}$ \\
\hline & (1) & (2) & (3) & (4) & (5) \\
\hline $\begin{array}{l}\text { Short-run effect of } \\
\text { Amnesty1 }\end{array}$ & $\begin{array}{l}.344^{* *} \\
(2.52)\end{array}$ & $\begin{array}{l}.150^{*} \\
(1.72)\end{array}$ & $\begin{array}{l}.144^{*} \\
(1.93)\end{array}$ & $\begin{array}{l}.149^{*} \\
(1.70)\end{array}$ & $\begin{array}{l}.141^{*} \\
(1.88)\end{array}$ \\
\hline $\begin{array}{l}\text { Short-run effect of } \\
\text { Amnesty2 }\end{array}$ & & $\begin{array}{l}.152 \\
(0.95)\end{array}$ & $\begin{array}{l}.061 \\
(0.53)\end{array}$ & $\begin{array}{l}.353 \\
(1.15)\end{array}$ & $\begin{array}{l}.228 \\
(1.06)\end{array}$ \\
\hline $\begin{array}{l}\text { Short-run effect of } \\
\text { Amnesty3 }\end{array}$ & & & $\begin{array}{l}.360 \\
(1.29)\end{array}$ & & $\begin{array}{l}.337 \\
(1.21)\end{array}$ \\
\hline $\begin{array}{l}\text { Long-run effect of } \\
\text { Amnesty } 1\end{array}$ & $\begin{array}{l}-.163^{* * *} \\
(3.11)\end{array}$ & $\begin{array}{l}-.113^{\star \star \star} \\
(2.97)\end{array}$ & $\begin{array}{c}-.099^{* \star \star} \\
(2.84)\end{array}$ & $\begin{array}{l}-.109^{* \star *} \\
(2.83)\end{array}$ & $\begin{array}{l}-.094^{* * *} \\
(2.67)\end{array}$ \\
\hline $\begin{array}{l}\text { Long-run effect of } \\
\text { Amnesty2 }\end{array}$ & & $\begin{array}{l}-.037 \\
(0.52)\end{array}$ & $\begin{array}{l}-.085^{\star} \\
(1.73)\end{array}$ & $\begin{array}{l}-.286^{\star \star} \\
(2.10)\end{array}$ & $\begin{array}{l}-.218^{\star \star} \\
(2.47)\end{array}$ \\
\hline $\begin{array}{l}\text { Long-run effect of } \\
\text { Amnesty3 }\end{array}$ & & & $\begin{array}{l}-.478^{* \star *} \\
(3.38)\end{array}$ & & $\begin{array}{l}-.437^{* * *} \\
(3.05)\end{array}$ \\
\hline $\begin{array}{l}\text { Time difference } \\
\text { between } 1^{\text {st }} \& 2^{\text {nd }} \\
\text { Amnesty (Short Run } \\
\text { Effect) }\end{array}$ & & & & $\begin{array}{l}-.027 \\
(1.05)\end{array}$ & $\begin{array}{c}-.022 \\
(1.19)\end{array}$ \\
\hline $\begin{array}{l}\text { Time difference } \\
\text { between } 1^{\text {st }} \& 2^{\text {nd }} \\
\text { Amnesty (Long Run } \\
\text { Effect) }\end{array}$ & & & & $\begin{array}{l}.028^{* *} \\
(2.15)\end{array}$ & $\begin{array}{l}.017^{\star} \\
(1.83)\end{array}$ \\
\hline $\begin{array}{l}\text { Log of Per Capita } \\
\text { Personal Income }\end{array}$ & $\begin{array}{l}2.107^{* * *} \\
(6.31)\end{array}$ & $\begin{array}{c}1.893^{* \star \star} \\
(7.31)\end{array}$ & $\begin{array}{c}1.525^{\star * *} \\
(6.54)\end{array}$ & $\begin{array}{c}1.856^{* * *} \\
(7.15)\end{array}$ & $\begin{array}{c}1.510^{* \star *} \\
(6.47)\end{array}$ \\
\hline $\begin{array}{l}\text { Log of Corporate } \\
\text { Income Tax Rate }\end{array}$ & $\begin{array}{l}1.071^{\star \star \star} \\
(5.99)\end{array}$ & $\begin{array}{l}.720^{\star \star \star} \\
(6.07)\end{array}$ & $\begin{array}{l}.709^{\star \star \star} \\
(6.91)\end{array}$ & $\begin{array}{l}.712^{\star \star \star} \\
(6.0 \odot)\end{array}$ & $\begin{array}{l}.702^{\star \star \star} \\
(6.83)\end{array}$ \\
\hline $\begin{array}{l}\text { Log of unemployment } \\
\text { rate }\end{array}$ & $\begin{array}{l}-.223^{* *} \\
(2.39)\end{array}$ & $\begin{array}{l}-.261^{* * *} \\
(4.20) \\
\end{array}$ & $\begin{array}{c}-.296^{* * *} \\
(5.43)\end{array}$ & $\begin{array}{c}-.263^{* \star *} \\
(4.24)\end{array}$ & $\begin{array}{l}-.296^{* * *} \\
(5.43)\end{array}$ \\
\hline Constant & $\begin{array}{c}-15.429^{* * *} \\
(4.38)\end{array}$ & $\begin{array}{c}-14.103^{* * *} \\
(5.25)\end{array}$ & $\begin{array}{c}-10.314^{* \star \star} \\
(4.29)\end{array}$ & $\begin{array}{c}-13.746^{* * *} \\
(5.11)\end{array}$ & $\begin{array}{c}-10.194^{* * *} \\
(4.24)\end{array}$ \\
\hline $\mathrm{R}^{2}$ & 0.269 & 0.195 & 0.240 & 0.196 & 0.242 \\
\hline No of Observations & 2072 & 3410 & $4 \odot 45$ & 3410 & 4045 \\
\hline $\begin{array}{l}\text { Model suggested by } \\
\text { Hausman test }\end{array}$ & Fixed Effects & Fixed Effects & Fixed Effects & Fixed Effects & Fixed Effects \\
\hline$\chi^{2}$ value & $\chi^{2}(92)=78.75$ & $\begin{array}{c}\text { Asymptotic } \\
\text { assumption not } \\
\text { met }\end{array}$ & $\chi^{2}(96)=91.30$ & $\chi^{2}(96)=79.71$ & $\chi^{2}(98)=83.37$ \\
\hline
\end{tabular}

Notes: Figures in parenthesis are t-statistics, $* * *$ indicates 1 percent significance level, **indicates 5 percent significance level, *indicates 10 percent significance level. 
Table 3.17b - Regression Results for Per Capita Corporate Income Tax Revenue (Log of per capita corporate income tax revenue as dependent variable and with budget surplus or shortfall variable)

\begin{tabular}{|c|c|c|c|c|c|}
\hline Variable & $\begin{array}{l}\text { States with one } \\
\text { Amnesty }\end{array}$ & $\begin{array}{c}\text { States with one } \\
\text { \& two } \\
\text { Amnesties }\end{array}$ & $\begin{array}{l}\text { States with one, } \\
\text { two, \& three } \\
\text { Amnesties }\end{array}$ & $\begin{array}{c}\text { States with one } \\
\text { \& two } \\
\text { Amnesties }\end{array}$ & $\begin{array}{l}\text { States with one, } \\
\text { two, \& three } \\
\text { Amnesties }\end{array}$ \\
\hline & (1) & (2) & (3) & (4) & (5) \\
\hline $\begin{array}{l}\text { Short-run effect of } \\
\text { Amnesty1 }\end{array}$ & $\begin{array}{l}.344^{* *} \\
(2.52)\end{array}$ & $\begin{array}{l}.152^{*} \\
(1.74) \\
\end{array}$ & $\begin{array}{l}.144^{\star} \\
(1.94) \\
\end{array}$ & $\begin{array}{l}.150^{*} \\
(1.72) \\
\end{array}$ & $\begin{array}{l}.141^{*} \\
(1.89) \\
\end{array}$ \\
\hline $\begin{array}{l}\text { Short-run effect of } \\
\text { Amnesty2 }\end{array}$ & & $\begin{array}{l}.154 \\
(0.96)\end{array}$ & $\begin{array}{l}.062 \\
(0.54)\end{array}$ & $\begin{array}{l}.339 \\
(1.11)\end{array}$ & $\begin{array}{l}.225 \\
(1.05)\end{array}$ \\
\hline $\begin{array}{l}\text { Short-run effect of } \\
\text { Amnesty3 }\end{array}$ & & & $\begin{array}{l}.372 \\
(1.33)\end{array}$ & & $\begin{array}{l}.349 \\
(1.25)\end{array}$ \\
\hline $\begin{array}{l}\text { Long-run effect of } \\
\text { Amnesty1 }\end{array}$ & $\begin{array}{l}-.163^{* * *} \\
(3.11)\end{array}$ & $\begin{array}{l}-.116^{* * *} \\
(3.02)\end{array}$ & $\begin{array}{l}-.100^{* * *} \\
(2.87)\end{array}$ & $\begin{array}{c}-.110^{* * *} \\
(2.88)\end{array}$ & $\begin{array}{c}-.095^{* * *} \\
(2.70)\end{array}$ \\
\hline $\begin{array}{l}\text { Long-run effect of } \\
\text { Amnesty2 }\end{array}$ & & $\begin{array}{l}-.038 \\
(0.55)\end{array}$ & $\begin{array}{l}-.088^{*} \\
(1.77)\end{array}$ & $\begin{array}{l}-.296^{\star *} \\
(2.18)\end{array}$ & $\begin{array}{l}-.221^{* *} \\
(2.51)\end{array}$ \\
\hline $\begin{array}{l}\text { Long-run effect of } \\
\text { Amnesty3 }\end{array}$ & & & $\begin{array}{c}-.490^{* * *} \\
(3.45)\end{array}$ & & $\begin{array}{c}-.449^{* * *} \\
(3.12)\end{array}$ \\
\hline $\begin{array}{l}\text { Time difference } \\
\text { between } 1^{\text {st }} \& 2^{\text {nd }} \\
\text { Amnesty (Short Run } \\
\text { Effect) }\end{array}$ & & & & $\begin{array}{l}-.025 \\
(1.00)\end{array}$ & $\begin{array}{c}-.021 \\
(1.17)\end{array}$ \\
\hline $\begin{array}{l}\text { Time difference } \\
\text { between } 1^{\text {st }} \& 2^{\text {nd }} \\
\text { Amnesty (Long Run } \\
\text { Effect) }\end{array}$ & & & & $\begin{array}{l}.029^{* *} \\
(2.22)\end{array}$ & $\begin{array}{l}.017^{*} \\
(1.85)\end{array}$ \\
\hline $\begin{array}{l}\text { Log of Per Capita } \\
\text { Personal Income }\end{array}$ & $\begin{array}{l}2.107^{* * *} \\
(6.29)\end{array}$ & $\begin{array}{c}1.915^{* \star *} \\
(7.38)\end{array}$ & $\begin{array}{c}1.544^{* * *} \\
(6.60)\end{array}$ & $\begin{array}{c}1.877^{* * *} \\
(7.22)\end{array}$ & $\begin{array}{c}1.529^{* * *} \\
(6.54)\end{array}$ \\
\hline $\begin{array}{l}\text { Log of Corporate } \\
\text { Income Tax Rate }\end{array}$ & $\begin{array}{l}1.071^{* \star *} \\
(5.99)\end{array}$ & $\begin{array}{l}.719^{\star \star \star} \\
(6.06)\end{array}$ & $\begin{array}{l}.707^{\star \star \star} \\
(6.89)\end{array}$ & $\begin{array}{l}.710^{* \star *} \\
(5.99)\end{array}$ & $\begin{array}{l}.699^{\star \star *} \\
(6.81)\end{array}$ \\
\hline $\begin{array}{l}\text { Log of unemployment } \\
\text { rate }\end{array}$ & $\begin{array}{l}-.223^{* *} \\
(2.37)\end{array}$ & $\begin{array}{l}-.247^{* * *} \\
(3.92)\end{array}$ & $\begin{array}{l}-.284^{* * *} \\
(5.13)\end{array}$ & $\begin{array}{l}-.249^{* \star *} \\
(3.94)\end{array}$ & $\begin{array}{l}-.284^{\star \star \star} \\
(5.13)\end{array}$ \\
\hline $\begin{array}{l}\text { Budget Surplus or } \\
\text { Shortfall as a percent } \\
\text { of Total Tax Revenue }\end{array}$ & $\begin{array}{l}.002 \\
(0.02)\end{array}$ & $\begin{array}{l}.072 \\
(1.29)\end{array}$ & $\begin{array}{l}.062 \\
(1.16)\end{array}$ & $\begin{array}{l}.077 \\
(1.38)\end{array}$ & $\begin{array}{l}.062 \\
(1.17)\end{array}$ \\
\hline Constant & $\begin{array}{c}-15.435^{* * *} \\
(4.36)\end{array}$ & $\begin{array}{c}-14.325^{* * *} \\
(5.33)\end{array}$ & $\begin{array}{c}-10.509^{* \star *} \\
(4.36)\end{array}$ & $\begin{array}{c}-13.973^{* * *} \\
(5.19)\end{array}$ & $\begin{array}{c}-10.390^{* * *} \\
(4.31)\end{array}$ \\
\hline $\mathrm{R}^{2}$ & 0.269 & 0.200 & 0.245 & 0.202 & 0.247 \\
\hline No of Observations & 2072 & 3410 & 4045 & 3410 & 4045 \\
\hline Model & Fixed Effects & Fixed Effects & Fixed Effects & Fixed Effects & Fixed Effects \\
\hline$\chi^{2}$ value & $\chi^{2}(93)=78.24$ & $\chi^{2}(94)=83.95$ & $\chi^{2}(97)=77.61$ & $\chi^{2}(97)=97.55$ & $\chi^{2}(99)=101.88$ \\
\hline
\end{tabular}

Notes: Figures in parenthesis are absolute t-statistics, ***indicates 1 percent significance level, $* *$ indicates 5 percent significance level, *indicates 10 percent significance level. 


\subsection{Summary and Conclusion}

Amid the fiscal stress faced by states during and after the most recent recession, many turned to offering tax amnesties as a way to generate additional tax revenue. In many of these cases the amnesty was the second, third, or even fourth amnesty offered by the state during the last 23 years. In this paper I examined whether the revenue effects of offering a tax amnesty change as the amnesty is offered on a repeated basis, something that has not been previously examined in the literature. I distinguish between the effect the amnesty has on revenue in the period accompanying the amnesty program (the short-run effect) and the effect the amnesty has on the permanent mean level of tax revenue (the long-run effect). I find that overall, when a state offers an amnesty for the first time, it produces revenue during the amnesty period but then harms revenue in the long run, which is consistent with the theory proposing that people respond to the amnesty by beginning to evade taxes in anticipation of additional future amnesties. Repeated broadbased amnesties fail to produce even additional short-run revenue, while creating significant long-run revenue losses due to reduced compliance that grow as additional amnesties are offered. Based on these results it is recommended that states avoid using tax amnesties on a repeated basis, and even the first offering is not clearly a revenue enhancement once the long run compliance effects are considered. 


\section{Chapter 4}

\section{Tax Amnesties and Compliance in the Long Run: A Time Series Analysis Revisited}

\subsection{Introduction}

Using a panel of quarterly tax data for all 50 states for 1980 to 2002, I explored the issue how the impact of a tax amnesty changes as it is offered more than once. The results show that the effect of offering an amnesty repeatedly is to change the revenue impact of the amnesty itself. When looking at the impact of a broad-based tax amnesty on total tax revenue, a state's first amnesty results in a short-run increase in revenue, but is accompanied by a long-run revenue loss, likely due to lower future compliance. Neither the second nor third amnesty produce significant short-run revenue, but they do create long-run revenue losses.

While analyzing the data, I used fixed effects and random effects models, which are believed to extract the information from all the amnesties of all states combined together without regard to the success or failure of an individual state. Therefore, in this chapter which is an extension of my previous research, I individually analyze the shortrun and long-run effects of the first amnesty in Colorado, Maine and West Virginia to determine if these amnesties were successful in bringing short-term and long-term revenues for the state treasury.

Another motivation for this study comes from the fact that except for Alm and Beck (1993), who examine the 1985 Colorado tax amnesty, no study has applied a time series method to analyze the effect of tax amnesty of any individual state. Given the popularity of amnesties among states, it is worth repeating an exercise to see if similar 
results hold for other states. Alm and Beck (1993) assume personal income tax as a proxy for total tax revenue arguing that amnesty collection from individual income tax was the largest source in Colorado which accounted for over 90 percent of the amnesty collection. However, according to Luitel and Tosun (forthcoming), for West Virginia's 1986 tax amnesty, individual income tax played a significantly smaller role, accounting for only slightly over 10 percent share in total amnesty collection. Moreover, of the 76 amnesties offered during the period of 1982-2004, 72 included all major state taxes, and only 4 were for a specific tax (e.g. income tax, sales tax and use taxes, etc.). Furthermore, we have examples of many states with no personal income tax that have offered tax amnesties. Therefore, an analysis of broader tax represented by the total tax revenue is justifiable.

In this study, I analyze 1985 Colorado amnesty, 1990 Maine amnesty and 1986 West Virginia amnesty using quarterly total tax revenue data. First I show that 1985 Colorado amnesty had no short-run or long-run impact on the tax collections, which is, as expected, consistent with the finding in the existing literature. Then I repeat the exercise to analyze 1990 Maine amnesty and 1986 West Virginia amnesty. I find that 1990 Maine amnesty and 1986 West Virginia amnesty raised tax revenues only in the short run and tax revenues actually fell in these states in the long run. These results confirm my finding in chapter 3 that an amnesty produces revenue during the amnesty period but harms revenue in the long run, but contrast with Alm and Beck's (1993) findings that "a typical amnesty seems unlikely to generate significant new revenue, but also seems unlikely to compromise voluntary compliance.” 


\subsection{States Background Information and Tax Amnesty Programs}

\subsubsection{States Background Information}

Colorado is the largest state among Colorado, Maine and West Virginia in terms of area, population, gross state product (GSP) and yearly state expenditure. Whereas Maine is the smallest state in terms of population, GSP and yearly state expenditure, area-wise West Virginia is the smallest one. Unemployment rate was recorded high in West Virginia, 13.1 percent in 1985, 11.8 percent in 1986 and 6.1 in 2002. It is the lowest in Maine, 4.4 percent in 2002. Among these three states, per capita tax burden, defined as total tax revenue divided by population, is lowest in Colorado. It is comparatively similar in Maine and West Virginia. States comparison at a glance is presented in Table 4.1.

Colorado was the lead state to run an amnesty which ran its first amnesty in 1985 followed by West Virginia in 1986. Only in 1990 did Maine follow the suit. However, Colorado and Maine ran their second amnesty almost simultaneously in 2003 and West Virginia followed the suit in 2004. Despite Colorado being the largest in terms of area, population and yearly state budget and Maine being the smallest in terms of population, GSP and yearly state expenditure, it is interesting to note that amnesty collection from the first amnesty was the lowest in Colorado in sharp contrasts to the highest in Maine. 
Table 4.1 - States Comparison at a Glance

\begin{tabular}{|l|c|c|c|}
\hline & Colorado & Maine & West Virginia \\
\hline Area & 103,717 sq mi. & $\begin{array}{c}30,862 \text { sq mi. } \\
(268,627 \text { sq km) }\end{array}$ & $\begin{array}{c}24,077 \text { sq mi. } \\
(62,359 \text { sq km) }\end{array}$ \\
\hline Population & $2,889,964(1980)$ & $1,124,660(1980)$ & $1,949,644(1980)$ \\
& $3,208,723(1985)$ & $1,162,936(1985)$ & $1,906,831(1985)$ \\
& $3,237,450(1986)$ & $1,170,126(1986)$ & $1,882,350(1986)$ \\
& $3,303,862(1990)$ & $1,231,296(1990)$ & $1,792,481(1990)$ \\
& $4,498,077(2002)$ & $1,297,750(2002)$ & $1,805,230(2002)$ \\
\hline Unemployment Rate & $5.9 \%(1980)$ & $7.7 \%(1980)$ & $9.4 \%(1980)$ \\
& $5.9 \%(1985)$ & $5.4 \%(1985)$ & $13.1 \%(1985)$ \\
& $7.4 \%(1986)$ & $5.3 \%(1986)$ & $11.8 \%(1986)$ \\
& $5.0 \%(1990)$ & $5.2 \%(1990)$ & $8.4 \%(1990)$ \\
Gross State Product & $5.8 \%(2002)$ & $4.4 \%(2002)$ & $6.1 \%(2002)$ \\
(Current \$ million) & $59,151(1980)$ & $10,136(1980)$ & $19,031(1980)$ \\
& $60,055(1985)$ & $16,112(1985)$ & $23,609(1985)$ \\
& $74,206(1990)$ & $17,501(1986)$ & $24,013(1986)$ \\
Total State & $179,410(2002)$ & $23,343(1990)$ & $28,336(1990)$ \\
Expenditure & $\$ 2,805$ million (1980) & $\$ 1,326$ million (1980) & $\$ 2,679$ million (1980) \\
(Current \$ million) & $\$ 4,817$ million (1985) & $\$ 1,948$ million (1985) & $\$ 3,343$ million (1985) \\
& $\$ 4,952$ million (1986) & $\$ 2,156$ million (1986) & $\$ 3,621$ million (1986) \\
& $\$ 6,510$ million (1990) & $\$ 3,044$ million (1990) & $\$ 4,212$ million (1990) \\
\hline Per Capita Tax & $\$ 16,823$ million (2002) & $\$ 6,264$ million (2002) & $\$ 9,409$ million (2002) \\
Burden & $\$ 962(1980)$ & $\$ 1,066(1980)$ & $\$ 1,118(1980)$ \\
(Constant \$ 2000) & $\$ 1,017(1985)$ & $\$ 1,300(1985)$ & $\$ 1,365(1985)$ \\
& $\$ 1,033(1986)$ & $\$ 1,397(1986)$ & $\$ 1,370(1986)$ \\
& $\$ 1,148(1990)$ & $\$ 1,612(1990)$ & $\$ 1,582(1990)$ \\
\hline
\end{tabular}




\subsubsection{The 1985 Colorado Amnesty}

Colorado ran its first tax amnesty program for 2 months between September 15 and November 15 in $1985 .{ }^{38}$ The amnesty was part of a larger on-going "Colorado Fair Share," a tax reform aimed at detecting tax evasion and promoting voluntary compliance with the tax code. The 1985 Colorado tax amnesty program was authorized by the Legislature and “Don't Say We Didn't Warn You” was the main slogan of the program. The amnesty was meant to be a onetime opportunity for individuals as well as businesses to pay any previously unpaid or underpaid taxes without penalties or criminal prosecution.

As can be seen in Table 4.2, the taxes included in the amnesty were as follows: individual income, corporate income, sales, use, gross ton mile, special fuel, cigarette, and liquor taxes. Installment payments were allowed as a method to pay taxes and penalties to encourage participation. While taxpayers who had received notices or billings for back taxes from the federal Internal Revenue Service were eligible for the amnesty, taxpayers who had received notices or billings from the Colorado tax department were not allowed to participate. After the conclusion of the amnesty, both penalties for the detected tax evasion as well as the personnel and other resources devoted to tax law enforcement were increased.

The amnesty was expected to collect \$5 million in revenues, however, actual collections exceeded $\$ 6.3$ million. Individual income tax was the largest source of amnesty revenues, which accounted for over 90 percent of the amnesty revenues.

\footnotetext{
${ }^{38}$ See Alm (1998), and Alm and Beck (1993).
} 
Table 4.2 - Taxes Included for the Amnesty

\begin{tabular}{|l|l|l|}
\hline \multicolumn{1}{|c|}{ Colorado 1985 Amnesty } & \multicolumn{1}{|c|}{ Maine 1990 Amnesty } & \multicolumn{1}{c|}{ West Virginia 1986 Amnesty } \\
\hline Individual Income Tax & Individual Income Tax & Business and Occupation Tax \\
\hline Corporate Income Tax & Corporate Income Tax & Business Registration \\
\hline Sales Tax & Sales Tax & Carrier Income Tax \\
\hline Use Tax & Excise duties & Consumers Sales Tax \\
\hline Gross Ton Mile & Fiduciary tax & Corporation Net Income Tax \\
\hline Special Fuel & Inheritance tax & $\begin{array}{l}\text { Gasoline \& Special Fuels - Excise } \\
\text { Tax }\end{array}$ \\
\hline Cigarette & Estate tax & $\begin{array}{l}\text { Gasoline \& Special Fuels - Sales } \\
\text { Tax }\end{array}$ \\
\hline Liquor Taxes & Forestry tax & Inheritance Tax \\
\hline & Withholding tax & Motor Carrier Registration \\
\hline & & Motor Carrier Road Tax \\
\hline & & Individual Income Tax \\
\hline & & Soft Drink Tax \\
\hline & & Use Tax \\
\hline & & Withholding \\
\hline
\end{tabular}

\subsubsection{The 1990 Maine Tax Amnesty}

The State of Maine ran its first tax amnesty program for 2 months between November 1, 1990 and December 31, 1990. ${ }^{39}$ Like Colorado’s, Maine’s amnesty program was also authorized by the Legislature and "Get To Us Before We Get To You" was the main

\footnotetext{
${ }^{39}$ See Warren Marketing Group, “Maine Tax Amnesty Report May 1991”.
} 
slogan of the program. The state authorities were concerned there could be a tremendous public outcry if taxes were raised before State of Maine would take steps to increase enforcement of the tax code. Therefore, before the amnesty was initiated, the Legislature armed the Maine State Tax Department with several strong new enforcement tools and the increased enforcement was integral to the promise of the tax amnesty. The amnesty program was also well publicized through various forms of media e.g. television, radio, newspaper, brochure etc. The amnesty program was budgeted $\$ 200,000$ with over 86 percent of the budget allocated for the advertising.

The amnesty program included all taxes: Individual income and withholding tax, corporate income tax, sales tax, excise duties, fiduciary tax, inheritance tax, estate tax, forestry tax etc. administered by the Maine State Tax Department. The amnesty did not forgive interests accrued on unpaid taxes but it allowed installment arrangements to pay the back taxes. It also allowed accounts receivable to participate in the amnesty. Table 4.3 presents comparative characteristics of tax amnesty programs of the three states.

Table 4.3 - Comparative Characteristics of Amnesty

\begin{tabular}{|l|c|c|c|}
\hline & Colorado & Maine & West Virginia \\
\hline Legislative Authorization & Yes & Yes & Yes \\
\hline Known Delinquent Participation? & No & Yes & Yes \\
\hline Installment Arrangement Permitted? & Yes & Yes & Yes \\
\hline Interest Payment Reduction? & No & No & No \\
\hline Stricter Penalties? & Yes & Yes & Yes \\
\hline Greater Funding for Enforcement? & Yes & Yes & No \\
\hline
\end{tabular}


The amnesty program expected to collect $\$ 15$ million in revenues, however, actual collections exceeded \$27 million. For Maine, sales and use tax were the largest source of amnesty collections, which accounted for 35 percent followed by individual income tax (31 percent) and corporate income tax (27 percent). Other miscellaneous taxes accounted for 7 percent in the amnesty collections.

\subsubsection{The 1986 West Virginia Tax Amnesty}

West Virginia ran a tax amnesty program for three months between October 1, 1986 and December 31, 1986. Like Colorado’s and Maine’s, West Virginia’s amnesty program was also authorized by the Legislature. This amnesty program included all taxes, licenses and fees administered by the West Virginia State Tax Department. The program included all types of liabilities, which included: Failure to file, under-reporting income, overstating deductions and exemptions, etc., failure to pay any tax, interest, penalty or additions to tax, liabilities established by audit assessment, estimated assessment, administrative decisions or court decisions, liabilities covered by assessments, liens, warrants, levies or attachments. The amnesty did not forgive interests accrued on unpaid taxes. In fact, the collected interest was fairly large, accounting 18 percent of total collections. However, the amnesty allowed installment arrangements to pay the back taxes. It is also important to note that unlike Colorado and Maine who increased both penalty and resources for the enforcement of the tax code after the conclusion of the amnesty in their respective state, 
the West Virginia tax department, although increased the penalty for tax evasion, failed to allocate funds or other resources for an increased enforcement of the tax code.

Table 4.4 compares the amnesty revenue collection by the three states. The 1986 West Virginia amnesty brought in total revenue of $\$ 10,466,517$, with 92.3 percent collected in FY 1987 and the remaining 7.7 percent collected mainly in FY 1988 and FY $1989 .{ }^{40}$ The business and occupation (B\&O) tax was the largest source of amnesty revenues, accounting for over 57 percent of the amnesty revenues followed by consumer sales and use tax (26 percent) and individual income and withholding tax (10 percent). Before 1987, individual income tax and consumer sales and use tax -- two major tax revenue sources for most other states -- played a significantly smaller role in West Virginia’s tax structure. Prior to 1987 tax reform -- which limited the B\&O tax to public utilities, electric power generators, natural gas storage and producers of synthetic fuel from coal -- West Virginia tax structure heavily relied on business taxation, which explains the large share of the B\&O tax in 1986 tax amnesty collections (Luitel and Tosun, forthcoming).

\footnotetext{
${ }^{40}$ The late collections in 1988 and 1989 were due to installment payment plan agreements with the Tax Department.
} 
Table 4.4 - Comparison of State Amnesty

\begin{tabular}{|l|c|c|c|}
\hline & Colorado & Maine & West Virginia \\
\hline Amnesty Period & $9 / 16 / 85-11 / 15 / 85$ & $11 / 1 / 90-12 / 31 / 90$ & $10 / 1 / 86-12 / 31 / 86$ \\
\hline Revenue Collection & $\$ 6.3$ million & $\$ 29$ million & $\$ 15.9$ million \\
\hline $\begin{array}{l}\text { Amnesty Per Capita (in } \\
\text { 2000 Constant \$) }\end{array}$ & $\$ 2.86$ & $\$ 28.87$ & $\$ 7.80$ \\
\hline Program Costs & $\$ 145,000$ & $\$ 200,000$ & n/a \\
\hline
\end{tabular}

\subsection{Empirical Methodology}

For the data analysis, I use two different time series methods - semi log time trend method and intervention analysis method. Time series methods are considered to be superior to other structural models in order to predict future movements of a variable. While other models predict the future movements of a variable by relating it to a set of variables in a causal or structural framework, time series methods use the past observations of the same variable. The beauty of the time series methods lies on the fact that they extract predictable movements of a variable from its own past observed data and then use this information to forecast its future movements. Alm and Beck (1993) give following reasons for the use of the time series approach: (i) It is difficult to specify the precise form of a complete structural model. (ii) Even if it is possible to write down a complete structural model, past data may not be available for all structural variables that are believed to affect the variable of interest. (iii) Even if such data are available, estimation of structural model might result in such large coefficient standard errors that forecasts also have unacceptably large errors. (iv) Future values of the structural variables 
may likewise be difficult to obtain, so that forecasting may not be feasible. (v) Moreover, Zellner and Palm (1974) show that a time series equation may be seen as a reduced from equation from a more complete structural form.

I collected quarterly total tax revenue data from the first quarter of 1980 to the fourth quarter of 2002. These data include the amnesty revenues over the relevant period. Descriptions of variables, and data sources, can be found in Appendix VIII and the summary statistics of the data is presented in Table 4.5. I start with the simple analysis of the semi-log time trend model and then proceed to a sophisticated method of intervention analysis. 
Table 4.5 - Summary Statistics

\begin{tabular}{|c|c|c|c|c|c|c|}
\hline & Variables & Obs & Mean & Std. Dev. & Min & Max \\
\hline \multirow{7}{*}{$\begin{array}{l}\frac{0}{0} \\
\frac{\pi}{0} \\
\frac{0}{0}\end{array}$} & Total Tax Revenue & 92 & $1,110,000,000$ & $398,000,000$ & $446,000,000$ & $2,160,000,000$ \\
\hline & $\begin{array}{l}\text { Short-run Effect of } \\
\text { Amnesty } 1\end{array}$ & 92 & 0.022 & 0.147 & 0 & 1 \\
\hline & $\begin{array}{l}\text { Long-run effect of } \\
\text { Amnesty } 1\end{array}$ & 92 & 0.761 & 0.429 & 0 & 1 \\
\hline & Quarter 1 & 92 & 0.250 & 0.435 & 0 & 1 \\
\hline & Quarter 2 & 92 & 0.250 & 0.435 & 0 & 1 \\
\hline & Quarter 3 & 92 & 0.250 & 0.435 & 0 & 1 \\
\hline & Quarter 4 & 92 & 0.250 & 0.435 & 0 & 1 \\
\hline \multirow{7}{*}{ 莺 } & Total Tax Revenue & 92 & $484,000,000$ & $140,000,000$ & $267,000,000$ & $937,000,000$ \\
\hline & $\begin{array}{l}\text { Short-run Effect of } \\
\text { Amnesty } 1\end{array}$ & 92 & 0.011 & 0.104 & 0 & 1 \\
\hline & $\begin{array}{l}\text { Long-run effect of } \\
\text { Amnesty } 1\end{array}$ & 92 & 0.533 & 0.502 & 0 & 1 \\
\hline & Quarter 1 & 92 & 0.250 & 0.435 & 0 & 1 \\
\hline & Quarter 2 & 92 & 0.250 & 0.435 & 0 & 1 \\
\hline & Quarter 3 & 92 & 0.250 & 0.435 & 0 & 1 \\
\hline & Quarter 4 & 92 & 0.250 & 0.435 & 0 & 1 \\
\hline \multirow{7}{*}{ 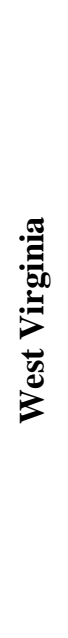 } & Total Tax Revenue & 92 & $698,000,000$ & $112,000,000$ & $515,000,000$ & $997,000,000$ \\
\hline & $\begin{array}{l}\text { Short-run Effect of } \\
\text { Amnesty } 1\end{array}$ & 92 & 0.011 & 0.104 & 0 & 1 \\
\hline & $\begin{array}{l}\text { Long-run effect of } \\
\text { Amnesty } 1\end{array}$ & 92 & 0.707 & 0.458 & 0 & 1 \\
\hline & Quarter 1 & 92 & 0.250 & 0.435 & 0 & 1 \\
\hline & Quarter 2 & 92 & 0.250 & 0.435 & 0 & 1 \\
\hline & Quarter 3 & 92 & 0.250 & 0.435 & 0 & 1 \\
\hline & Quarter 4 & 92 & 0.250 & 0.435 & 0 & 1 \\
\hline
\end{tabular}




\subsubsection{Semi-log Time Trend Analysis Results}

I estimated a semi-log linear time trend model of the form:

$$
\ln \left(Y_{t}\right)=b_{0}+b_{1} T_{t}+u_{t} \ldots \ldots \ldots \ldots \ldots \ldots \ldots \ldots \ldots
$$

where $\ln \left(Y_{t}\right)$ represents natural log of total tax revenue, $T_{t}$ is the time variable which varies from 1 for the first quarter of 1980 to 92 for the fourth quarter of 2002, $u_{t}$ is the

error term and follows $N\left(0, \sigma^{2}\right) . \mathrm{b}_{0}$ and $\mathrm{b}_{1}$ are the usual OLS parameters. I estimate this equation for Colorado, Maine and West Virginia over the entire period and over the two sub periods before and after amnesty separately for each of the three states. The results are presented in Table 4.6.

The idea is that if there is a change in the growth rate of tax collections over the sub-periods before and after the amnesty, the one should be able to detect some statistically significant change in either the intercept or the slope parameter. I find that the intercept and slope parameters are always positive and significant. This can be interpreted to suggest that with time growth rate of revenue collection increases.

Second, I introduce the amnesty variable and run the same regression. The results for this equation are also presented in Table 4.6. I find that the coefficient of amnesty variable is negative and barely significant for Colorado at 10 percent level but negative and consistently significant for Maine and West Virginia. I also try the model including another amnesty related variable. This is an interaction term between time and amnesty variables and obtained by multiplying the time variable with the amnesty variable $(A \times T)$. This specification allows us to test for a different intercept and slope change from the 
amnesty variable. Again, I find that the coefficient of $\mathrm{A} \times \mathrm{T}$ variable is negative for all the three states but it is found to be significant only for Maine. These results confirm that only Colorado amnesty had insignificant impact on the growth rate of tax collection but the growth rates of tax collection were negatively affected in Maine and West Virginia after their respective amnesty periods.

Table 4.6 - Total Tax Time Trend Results for Colorado

\begin{tabular}{|c|c|c|c|c|c|c|}
\hline Period & $\begin{array}{c}\text { No of } \\
\text { Observations }\end{array}$ & Constant & Time & Amnesty & $\begin{array}{c}\text { Amnesty } x \\
\text { Time }\end{array}$ & $\mathbf{R}^{2}$ \\
\hline \multicolumn{7}{|l|}{ Colorado } \\
\hline $1^{\text {st }}$ qtr $80-4^{\text {th }}$ qtr 02 & 92 & $\begin{array}{c}20.21^{* * *} \\
(682.56)\end{array}$ & $\begin{array}{c}0.01^{* * *} \\
(21.89)\end{array}$ & - & - & 0.84 \\
\hline $1^{\text {st }}$ qtr $80-2^{\text {nd }}$ qtr 85 & 22 & $\begin{array}{c}20.22^{* * *} \\
(296.39)\end{array}$ & $\begin{array}{l}0.01^{* *} \\
(2.57)\end{array}$ & - & - & 0.24 \\
\hline $3^{\text {rd }}$ qtr $85-4^{\text {th }}$ qtr 02 & 70 & $\begin{array}{c}20.13^{* * *} \\
(412.79)\end{array}$ & $\begin{array}{l}0.01^{* * *} \\
(16.45)\end{array}$ & - & - & 0.80 \\
\hline $1^{\text {st }}$ qtr $80-4^{\text {th }}$ qtr 02 & 92 & $\begin{array}{c}20.23^{* * *} \\
(650.48)\end{array}$ & $\begin{array}{l}0.01^{* * *} \\
(16.25)\end{array}$ & $\begin{array}{l}-0.09^{*} \\
(1.79)\end{array}$ & - & 0.85 \\
\hline $1^{\text {st }}$ qtr $80-4^{\text {th }}$ qtr 02 & 92 & $\begin{array}{c}20.22 * * * \\
(327.47)\end{array}$ & $\begin{array}{c}0.01^{* * *} \\
(2.84)\end{array}$ & $\begin{array}{l}-0.09 \\
(1.10)\end{array}$ & $\begin{array}{c}-0.0001 \\
(0.04)\end{array}$ & 0.85 \\
\hline \multicolumn{7}{|l|}{ Maine } \\
\hline $1^{\text {st }}$ qtr $80-4^{\text {th }}$ qtr 02 & 92 & $\begin{array}{l}19.55^{* * * *} \\
(617.82)\end{array}$ & $\begin{array}{l}.01 * * * \\
(14.81)\end{array}$ & - & - & 0.70 \\
\hline $1^{\text {st }}$ qtr $80-4^{\text {th }}$ qtr 90 & 43 & $\begin{array}{l}19.41^{* * *} \\
(658.93)\end{array}$ & $\begin{array}{l}.016^{* * *} \\
(13.90)\end{array}$ & - & - & 0.82 \\
\hline $1^{\text {st }}$ qtr $91-4^{\text {th }}$ qtr 02 & 49 & $\begin{array}{c}19.56^{* * *} \\
(170.42)\end{array}$ & $\begin{array}{l}.01 * * * \\
(5.01)\end{array}$ & - & - & 0.34 \\
\hline $1^{\text {st }}$ qtr $80-4^{\text {th }}$ qtr 02 & 92 & $\begin{array}{l}19.51^{* * *} \\
(585.33)\end{array}$ & $\begin{array}{l}.011^{* * *} \\
(10.13)\end{array}$ & $\begin{array}{c}-0.168 * * * \\
(2.78)\end{array}$ & - & 0.72 \\
\hline $1^{\text {st }}$ qtr $80-4^{\text {th }}$ qtr 02 & 92 & $\begin{array}{l}19.41^{* * *} \\
(459.82)\end{array}$ & $\begin{array}{l}.02 * * * \\
(9.70) \\
\end{array}$ & $\begin{array}{c}0.15 \\
(1.47) \\
\end{array}$ & $\begin{array}{c}-.0079 * * * \\
(3.67) \\
\end{array}$ & 0.77 \\
\hline \multicolumn{7}{|l|}{ West Virginia } \\
\hline $1^{\text {st }}$ qtr $80-4^{\text {th }}$ qtr 02 & 92 & $\begin{array}{c}20.14^{* * *} \\
(967.83)\end{array}$ & $\begin{array}{c}0.004 * * * \\
(11.79)\end{array}$ & - & - & 0.61 \\
\hline $1^{\text {st }}$ qtr $80-3^{\text {rd }}$ qtr 86 & 27 & $\begin{array}{c}20.14^{* * *} \\
(796.98)\end{array}$ & $\begin{array}{c}0.006^{* * * *} \\
(4.03)\end{array}$ & - & - & 0.39 \\
\hline $4^{\text {th }}$ qtr $86-4^{\text {th }}$ qtr 02 & 65 & $\begin{array}{l}20.05^{* * * *} \\
(454.29)\end{array}$ & $\begin{array}{c}0.005^{* * *} \\
(8.36)\end{array}$ & - & - & 0.53 \\
\hline $1^{\text {st }}$ qtr $80-4^{\text {th }}$ qtr 02 & 92 & $\begin{array}{l}20.15^{* * * *} \\
(993.47)\end{array}$ & $\begin{array}{c}0.005^{* * *} \\
(9.67)\end{array}$ & $\begin{array}{c}-0.097 * * * \\
(2.75)\end{array}$ & - & 0.64 \\
\hline $1^{\text {st }}$ qtr $80-4^{\text {th }}$ qtr 02 & 92 & $\begin{array}{l}20.14 * * * \\
(529.53) \\
\end{array}$ & $\begin{array}{c}0.01^{* * *} \\
(2.68) \\
\end{array}$ & $\begin{array}{l}-0.09 \\
(1.62) \\
\end{array}$ & $\begin{array}{c}-0.0005 \\
(0.20) \\
\end{array}$ & 0.64 \\
\hline
\end{tabular}

Notes: Figures in parenthesis are absolute t-statistics, ${ }^{* * *}$ indicates 1 percent significance level, ${ }^{* *}$ indicates 5 percent significance level, *indicates 10 percent significance level. 


\subsubsection{Time Series Intervention Analysis Results}

A more sophisticated method is the multivariate ARIMA or MARIMA model which I use for the intervention analysis of the amnesty in these three states. Following Box and Tao (1975) and Alm and Beck (1993), I model a discrete amnesty intervention as an additive effect of the amnesty on tax revenue. For the analysis, I include the main variables of interest to estimate the impact of the offering of a tax amnesty on real tax revenue, in both the short run and long run. To do this I include two variables for each amnesty. The first captures the short-run effect, and is simply a dummy variable equal to one only during the period for which the amnesty is active. The second, to capture the long run effect, is a dummy variable equal to zero prior to the offering of the tax amnesty and one for every period after the amnesty is offered, forever. The first of these two variables, the short run effect, captures any upward spike in the revenue collections during the period the amnesty is offered. This would be the revenue generated from the collection of back taxes during the amnesty. The second, the long run effect, captures any permanent shift in the mean of the series that begins with the date the amnesty is offered. This potentially includes two effects, the first being the evaders who now come back into the tax system, permanently increasing revenue, and the second being an increase in tax evasion as other taxpayers see the offering of the amnesty as a sign of a low cost of switching to tax evasion.

Because I would like to determine both the short-run and long-run impact of an amnesty, I include these two variables separately. It is possible that the initial (short-run) revenue brought in from overdue taxes will be positive; however, a priori it is difficult to 
be sure of the sign of the long-run effect variable. If the dominant effect of the amnesty is to bring evaders back into the tax system, then long-run revenue will rise. On the other hand, if the dominant effect is to discourage future compliance, increasing evasion, then long-run revenue will fall. If both effects are present, the long-run effect will be estimated close to zero.

Table 4.7 - Time Series Results

\begin{tabular}{|c|c|c|c|c|c|}
\hline \multicolumn{2}{|c|}{$\begin{array}{c}\text { Colorado } \\
\text { (Model:1, 1, 0, 1) }\end{array}$} & \multicolumn{2}{|c|}{$\begin{array}{c}\text { Maine } \\
\text { (Model:2, 1, 0,0) }\end{array}$} & \multicolumn{2}{|c|}{$\begin{array}{c}\text { West Virginia } \\
\text { (Model:1, 1, 0, 1) }\end{array}$} \\
\hline Constant & $\begin{array}{c}21.86 * * * \\
(41.66)\end{array}$ & Constant & $\begin{array}{c}20.87 * * * \\
(27.94)\end{array}$ & Constant & $\begin{array}{c}23.39 * * * \\
(3.67)\end{array}$ \\
\hline AR (1) & $\begin{array}{c}0.385^{* * *} \\
(4.08)\end{array}$ & AR (1) & $\begin{array}{c}0.275^{* *} \\
(2.55) \\
\end{array}$ & AR (1) & $\begin{array}{c}0.215^{* *} \\
(1.99) \\
\end{array}$ \\
\hline SAR (4) & $\begin{array}{c}0.948 * * * \\
(37.096)\end{array}$ & AR (2) & $\begin{array}{c}0.268^{* *} \\
(2.46)\end{array}$ & SAR (4) & $\begin{array}{c}0.991 * * * \\
(53.80)\end{array}$ \\
\hline SMA (4) & $\begin{array}{c}-0.489 * * * \\
(4.594)\end{array}$ & SAR (4) & $\begin{array}{c}0.952 * * * \\
(24.94)\end{array}$ & SMA (4) & $\begin{array}{c}-0.743^{* * *} \\
(8.99)\end{array}$ \\
\hline $\begin{array}{l}\text { Short run effect } \\
\text { of amnesty }\end{array}$ & $\begin{array}{c}0.034 \\
(0.459)\end{array}$ & $\begin{array}{l}\text { Short run effect } \\
\text { of amnesty }\end{array}$ & $\begin{array}{c}0.152 * * * \\
(2.88)\end{array}$ & $\begin{array}{l}\text { Short run effect } \\
\text { of amnesty }\end{array}$ & $\begin{array}{c}0.127^{* *} \\
(2.01)\end{array}$ \\
\hline $\begin{array}{l}\text { Long run effect } \\
\text { of amnesty }\end{array}$ & $\begin{array}{l}-0.098 \\
(1.287)\end{array}$ & $\begin{array}{l}\text { Long run effect } \\
\text { of amnesty }\end{array}$ & $\begin{array}{c}-0.121^{* *} \\
(2.27)\end{array}$ & $\begin{array}{l}\text { Long run effect } \\
\text { of amnesty }\end{array}$ & $\begin{array}{c}-0.118^{* * *} \\
(3.10)\end{array}$ \\
\hline $\begin{array}{l}\text { Number of } \\
\text { observations }\end{array}$ & 87 & $\begin{array}{l}\text { Number of } \\
\text { observations }\end{array}$ & 86 & $\begin{array}{l}\text { Number of } \\
\text { observations }\end{array}$ & 87 \\
\hline $\mathrm{R}^{2}$ & 0.93 & $\mathrm{R}^{2}$ & 0.94 & $\mathrm{R}^{2}$ & 0.83 \\
\hline BIC criteria & -4.482 & BIC criteria & -5.109 & BIC criteria & -5.141 \\
\hline
\end{tabular}

Notes: Figures in parenthesis are absolute t-statistics, ${ }^{* * *}$ indicates 1 percent significance level, $* *$ indicates 5 percent significance level, *indicates 10 percent significance level.

The MARIMA intervention analysis results are shown in Table 4.7 for Colorado, Maine and West Virginia. According to Table 4.7, for Colorado, the short-run coefficient is positive but insignificant and the long-run coefficient is negative but insignificant. These results suggest that the 1985 Colorado amnesty had no impact on revenues neither in the short run nor in the long run. However, for Maine and West Virginia, I obtain entirely different results. Table 4.7 also shows that the short-run coefficients to be 
positive and significant and the long-run coefficients to be negative and significant for both Maine and West Virginia. These results strongly suggest that both 1990 Maine amnesty and 1986 West Virginia amnesty were able to raise revenues in the short run only and revenues fell in these states in the long run.

There are a couple of explanations for such a sharp difference in result. First and the most important one is that Colorado didn’t allow known delinquents to participate in the amnesty but both Maine and West Virginia did. Since known delinquents are already identified by the tax department, it is quite possible that the amnesty simply accelerated the revenue collection from such delinquent taxpayers in Maine and West Virginia, which was not possible in Colorado. Second, the amnesty collection in Colorado was not only the lowest among the three states but also one of the low, ranking 51 out of 76 in terms of absolute revenue collection and 52 out of 76 in terms of per capita revenue collection (see Chapter 3, pp. 68-71). Therefore, the 1985 Colorado amnesty was of such a miniscule size that it had no effect on the compliance decision of individuals for the per capita tax burden is the lowest among the three states. Moreover, also note that 1985 Colorado amnesty was accompanied by greater enforcement efforts and although 1990 Maine amnesty was accompanied by greater enforcement efforts, 1986 West Virginia amnesty was not. Therefore, different results for differently designed tax amnesties are possible. The bottom line is that the results based on analysis of the tax amnesty in one state cannot be generalized. 


\subsection{Summary and Conclusion}

Except for Alm and Beck (1993), who examine the 1985 Colorado tax amnesty, no study has applied a time series method to analyze the effect of tax amnesty of any individual state. However, Alm and Beck (1993) assume personal income tax as a proxy for total tax revenue arguing that amnesty collection from individual income tax was the largest source in Colorado which accounted for over 90 percent of the amnesty collection. According to Luitel and Tosun (forthcoming), for West Virginia's 1986 tax amnesty, individual income tax played a significantly smaller role, accounting for only slightly over 10 percent share in total amnesty collection. Moreover, of the 76 amnesties offered during the period of 1982-2004, 72 included all major state taxes, and only 4 were for a specific tax. Furthermore, states with no personal income tax also have offered tax amnesties.

In this study, therefore, using quarterly total tax revenue data, I individually analyze the short-run and long-run effects of 1985 Colorado amnesty, 1990 Maine amnesty and 1986 West Virginia amnesty in order to determine if these amnesties were successful in bringing short-term and long-term revenues for the state treasury. I find that 1985 Colorado amnesty had no short-run or long-run impact on the tax collections, which is, as expected, consistent with the finding in the existing literature. However, I also find that, in sharp contrast to 1985 Colorado amnesty results, 1990 Maine amnesty and 1986 West Virginia amnesty raised tax revenues only in the short run and tax revenues actually fell in these states in the long run. 


\section{Chapter 5}

\section{Future Research}

While undertaking the research for my dissertation, I have identified several issues that need further work, and I expect to pursue several of them in future. First of all, the research on VAT could potentially contribute more directly to the debate about the comparison of a RST and a VAT. The results of this study indicate that an increase in reliance on VAT decreases VAT evasion. Is VAT really superior to RST on the ground of evasion? This can be investigated by comparing the intercept and slopes of respective taxes' evasion. Another extension would be to determine whether the decrease in VAT evasion as a result of an increase in its reliance is an isolated event or also true of other taxes. Further research in this area is desirable.

Similarly, analyzing quarterly revenue data of individual income tax, sales tax and total tax, for the period from 1980 to 2003, I find that the effect of offering an amnesty repeatedly is to change the revenue impact of the amnesty itself. When looking at the impact of a broad-based tax amnesty on total tax revenue, a state's first amnesty results in a short-run increase in revenue, but is accompanied by a long-run revenue loss, likely due to lower future compliance. Neither the second nor third amnesty produce significant short-run revenue, but they do create long-run revenue losses. I used fixed effects and random effects models for the analysis, which are believed to extract the information from all the amnesties of all states combined together without regard to the success or failure of an individual state. What determines the successes or the failures of the amnesty has not been addressed yet. For this analysis of each amnesty in each state 
separately and determine if those amnesties were successful in each individual state is necessary. Therefore, the current study, which is an extension of my research in Chapter 3 , is a step toward that direction. Only after complete analysis of each amnesty in each state, will it be possible to investigate the determinants of a successful amnesty.

A second line of research pertains to the competing theories of the causes of a tax amnesty. Two competing theories of the causes of tax amnesties have been proposed so far - one by Dubin, Graetz and Wilde (1992) and the other by Posner (2000). Dubin, Graetz and Wilde (1992) find the level of IRS auditing in a state to be the cause of an amnesty. If the IRS is active in a state, then that state is less likely to run a tax amnesty program and vice versa. Posner (2000), on the other hand, finds unstable government to be the cause of an amnesty. However, a casual observation of the data between the periods 1982 to 2004 also shows a neighborhood effect. That is, neighboring (especially contiguous) states are more prone to offer an amnesty. For example Arizona (1982-84) and California (1984-85), Missouri (1983) and Illinois (1984), Missouri (1983) and Kansas (1984), Kansas (1984) and Oklahoma (1984), Oklahoma (1984) and Texas (1984), North Dakota (1983) and Minnesota (1984) etc. A spatial econometric analysis is essential to determine whether the neighborhood effect causes an amnesty, which has been left for future research. 


\section{Appendix I - Tax Structure for Individual Sample OECD Countries}
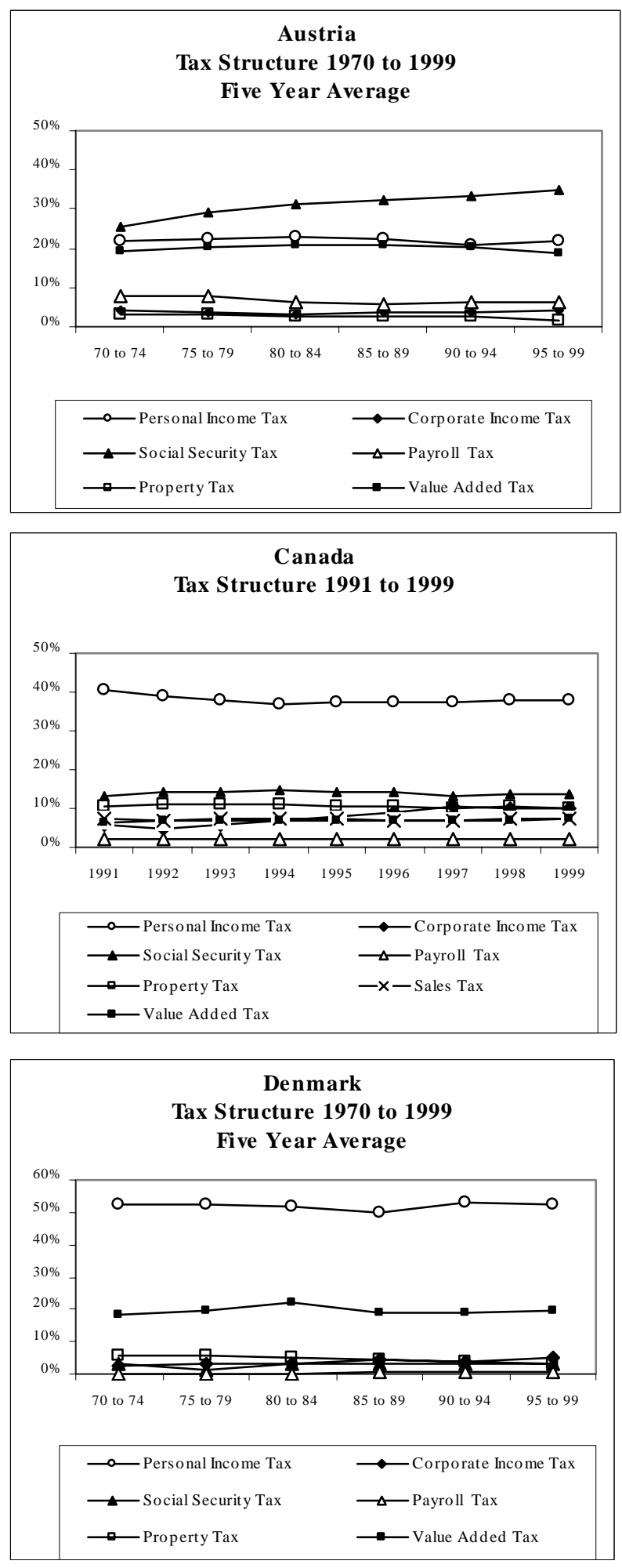

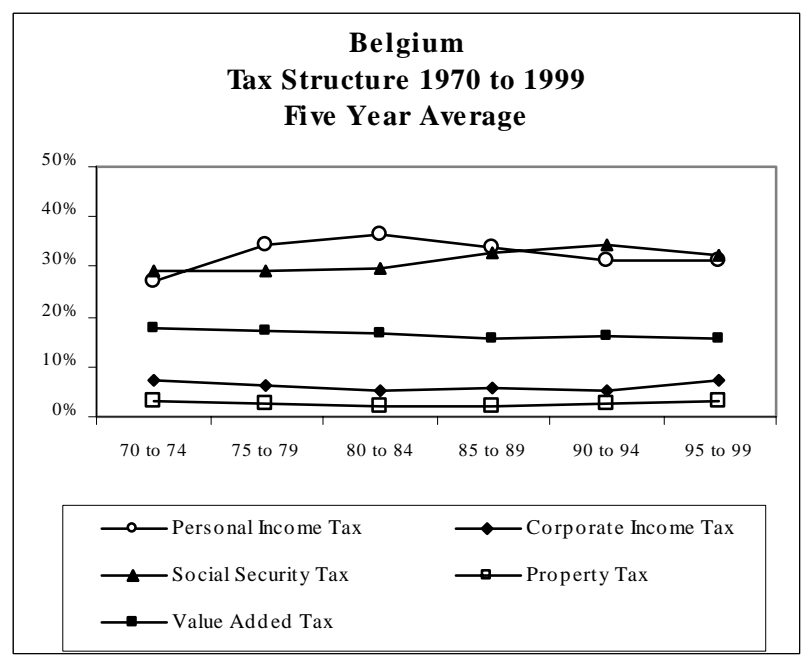

\section{Czech Republic}

Tax Structure 1993 to 1999

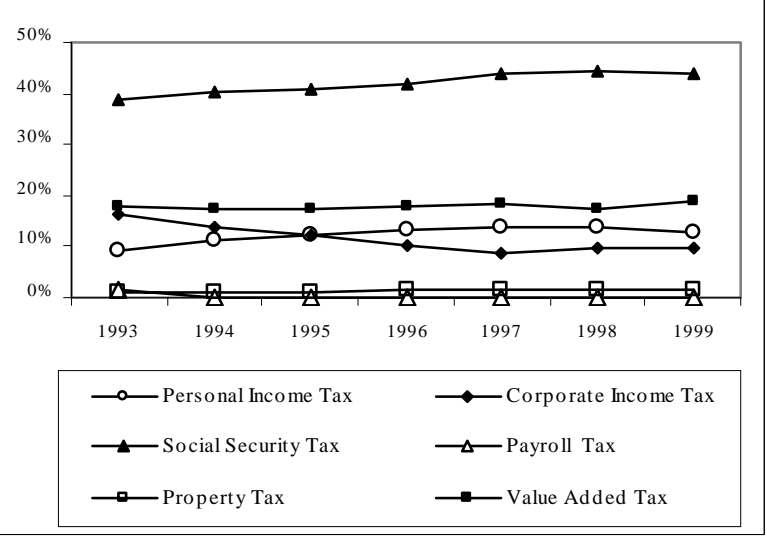

Finland

Tax Structure 1994 to 1999

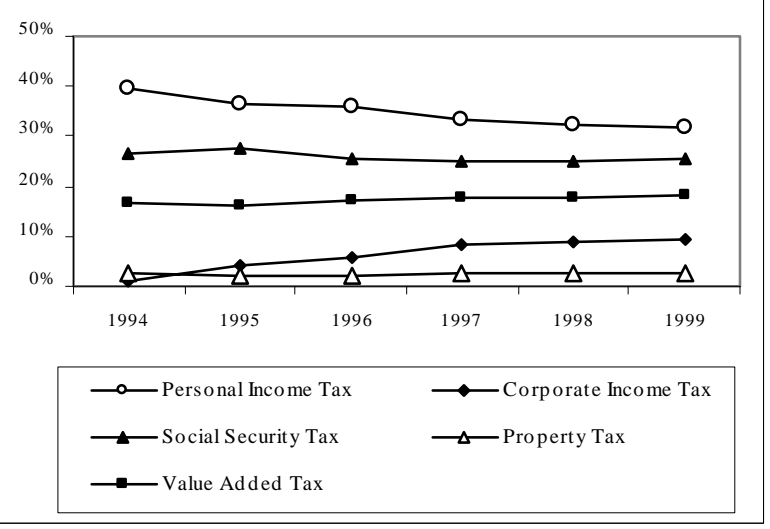



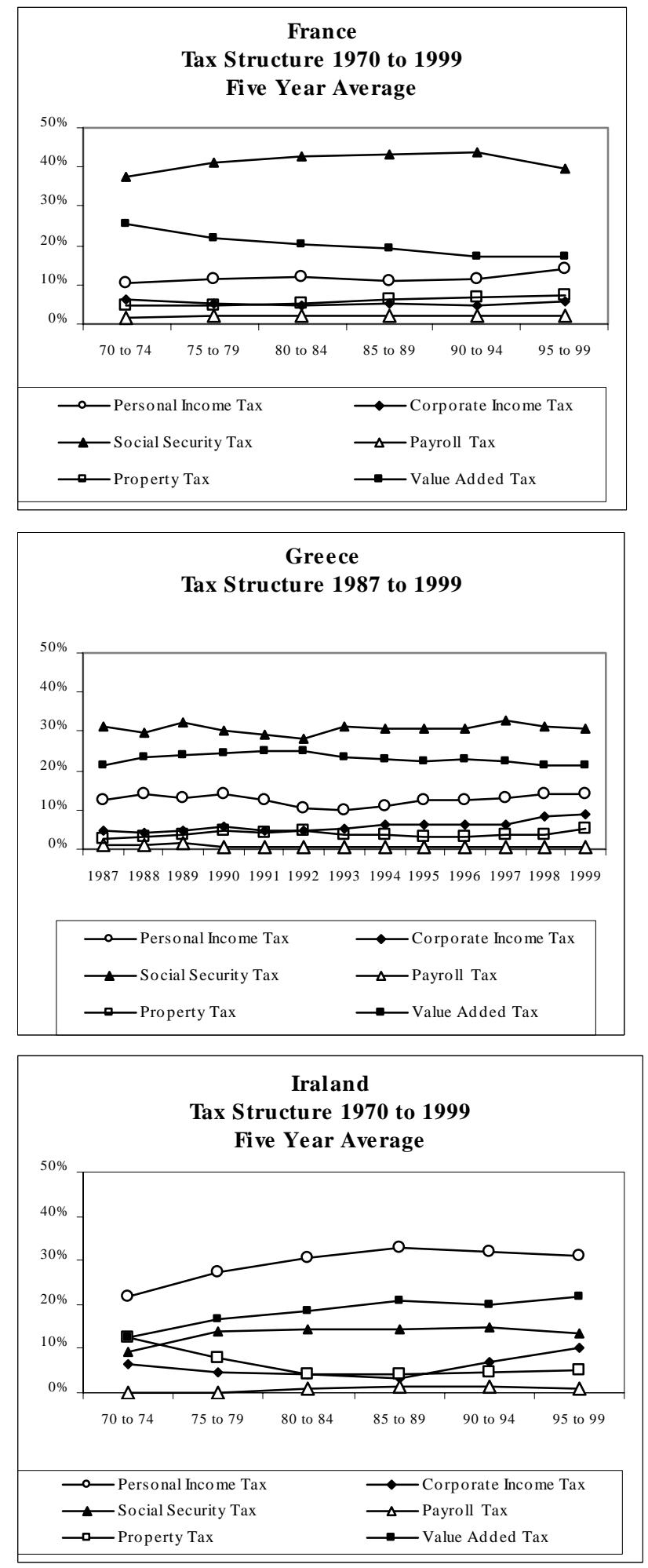

\section{Germany}

Tax Structure 1970 to 1999

Five Year Average
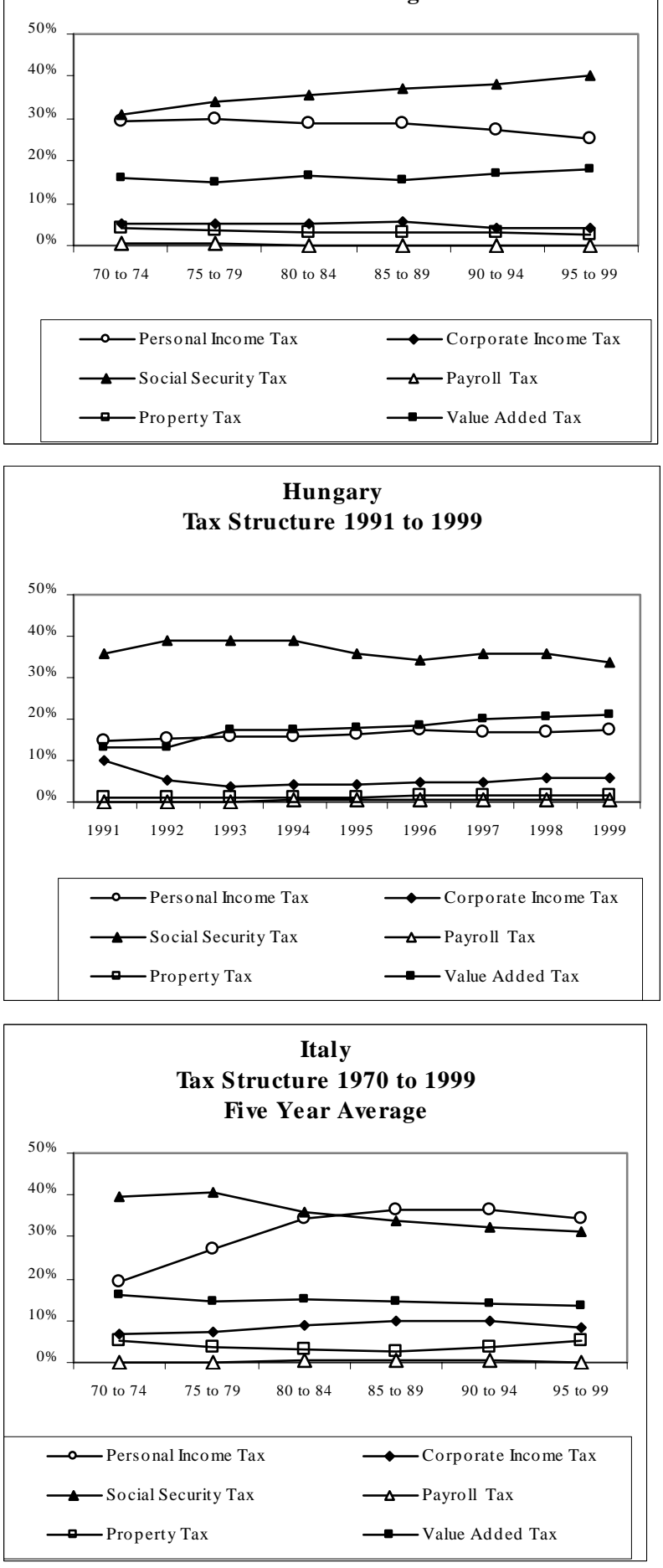

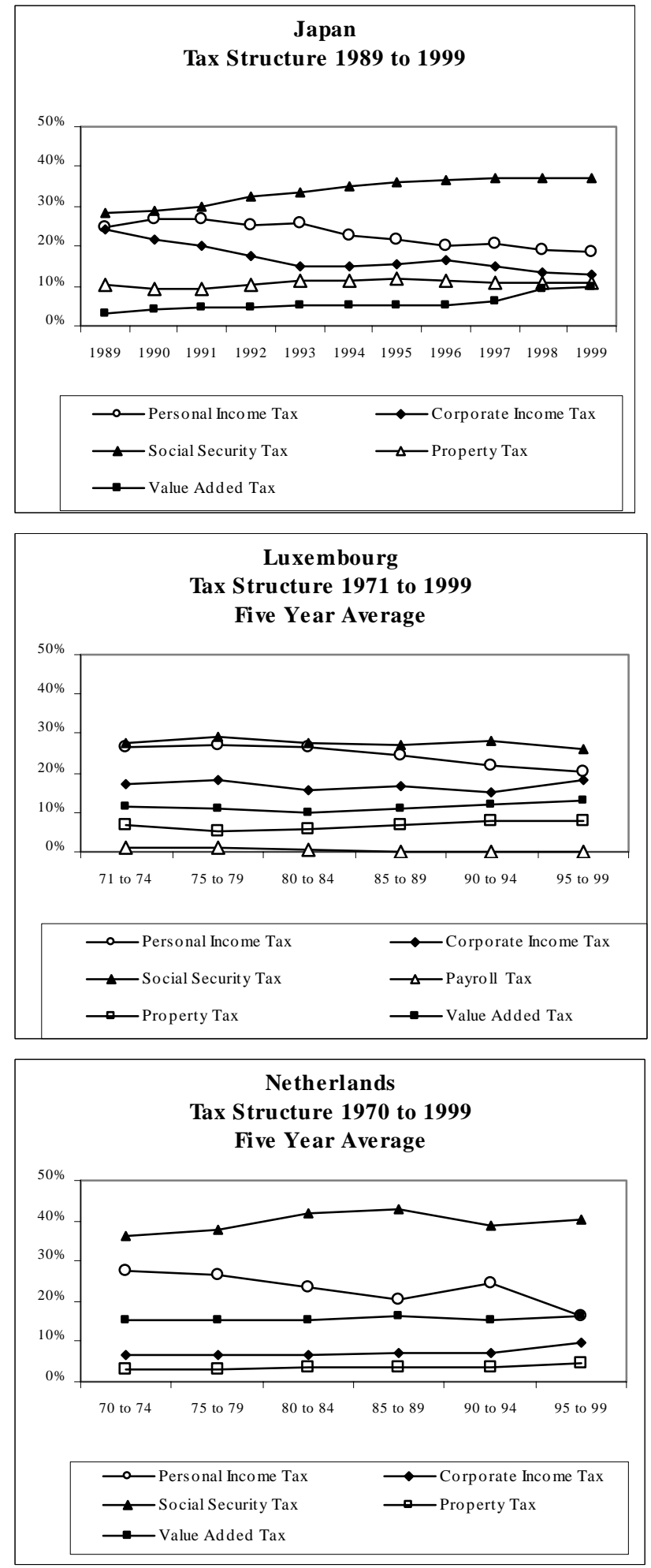

\section{Korea}

Tax Structure 1977 to 1999

Five Year Average

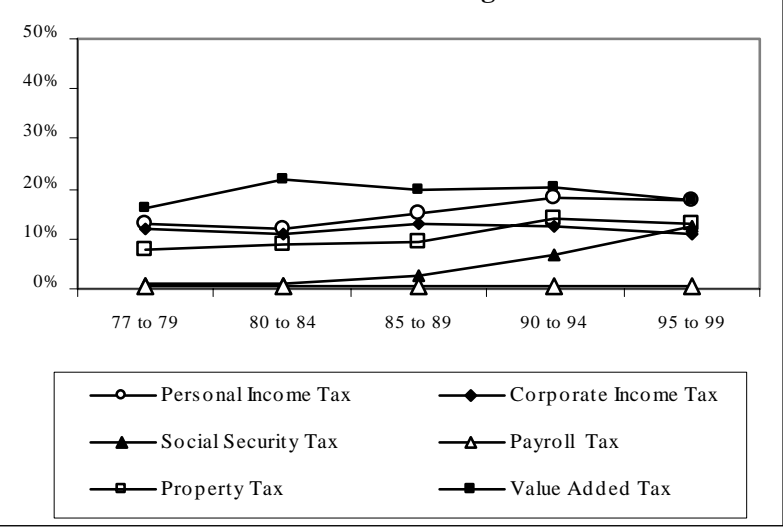

\section{Mexico}

Tax Structure 1980 to 1999

Five Year Average

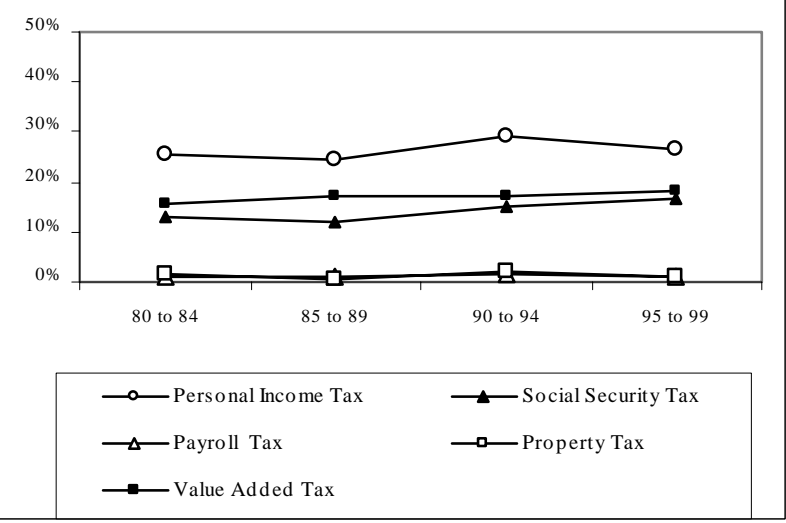

New Zealand

Tax Structure 1986 to 1999

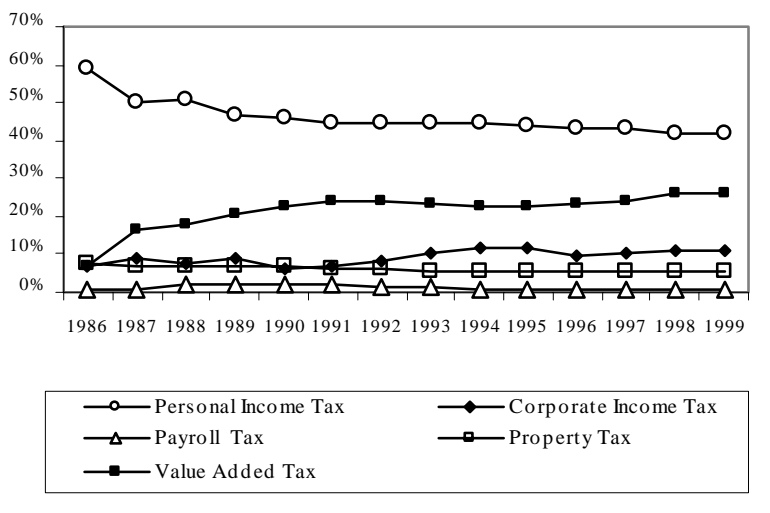



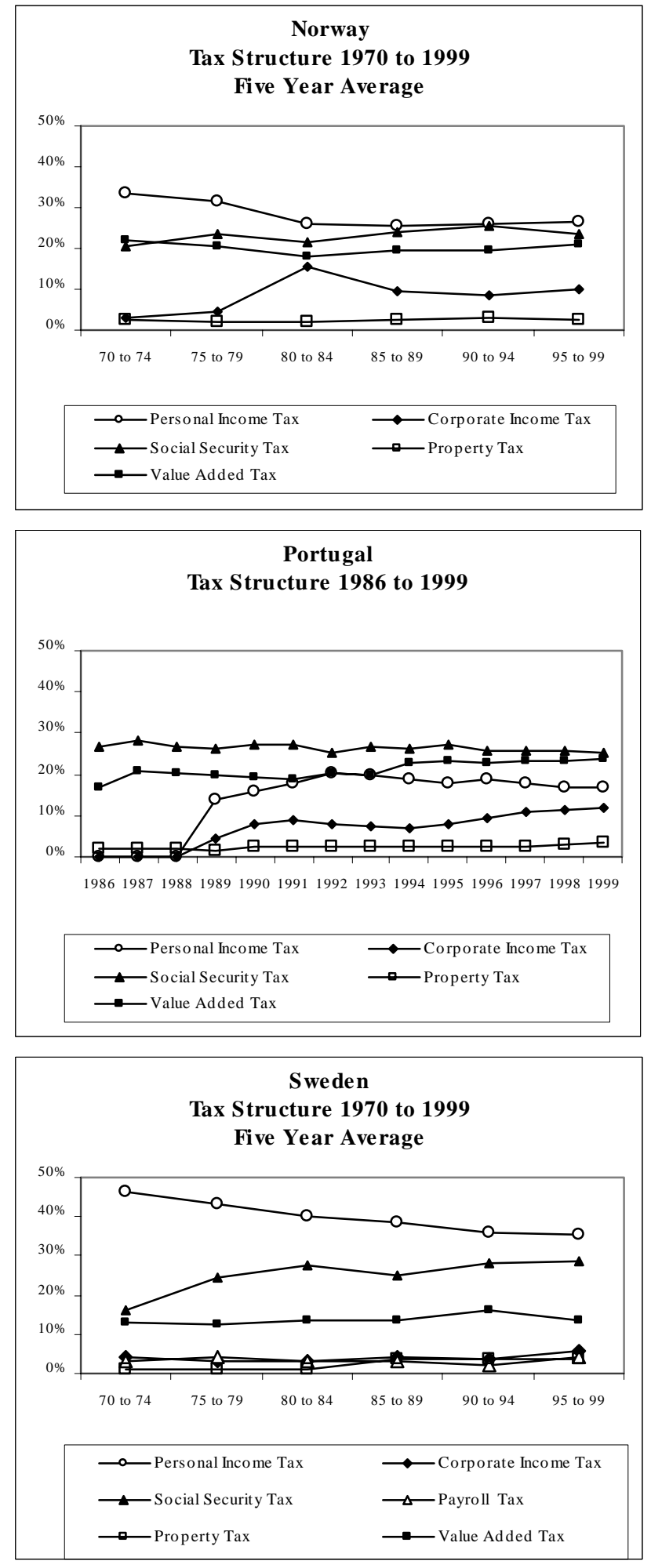

Poland

Tax Structure 1993 to 1999

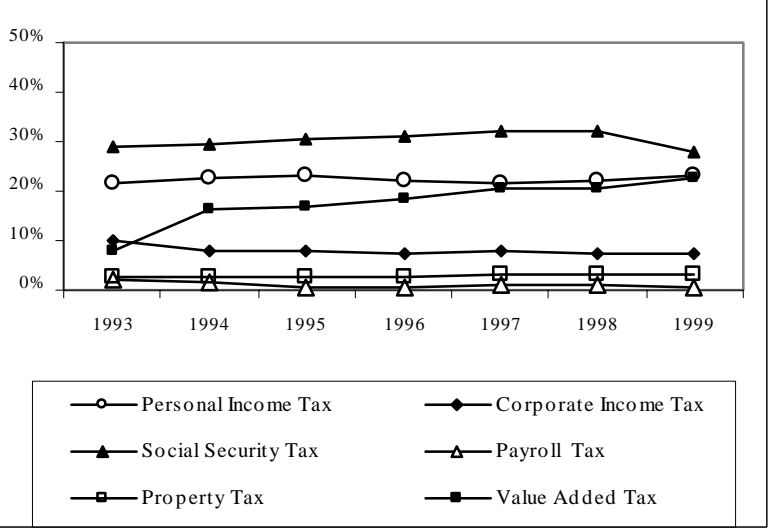

Spain

Tax Structure 1986 to 1999

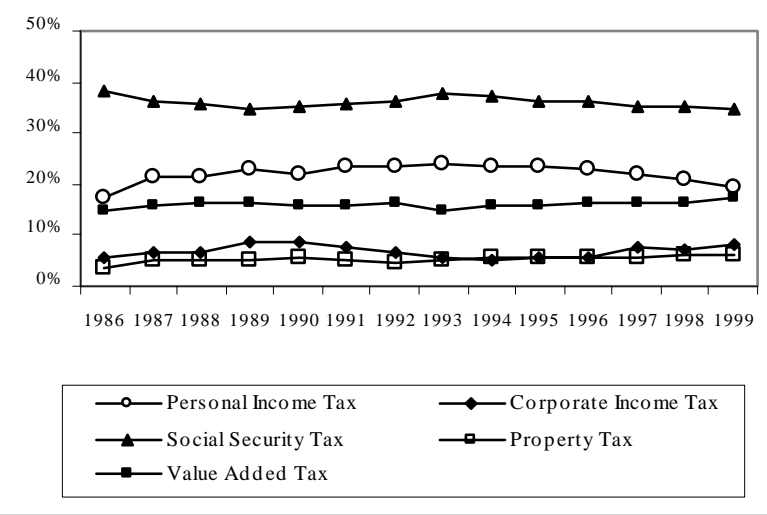

Turkey

Tax Structure 1985 to 1999

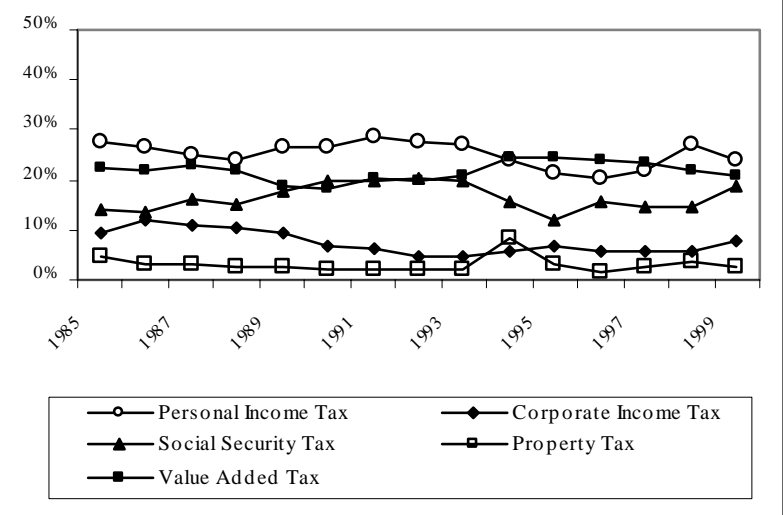




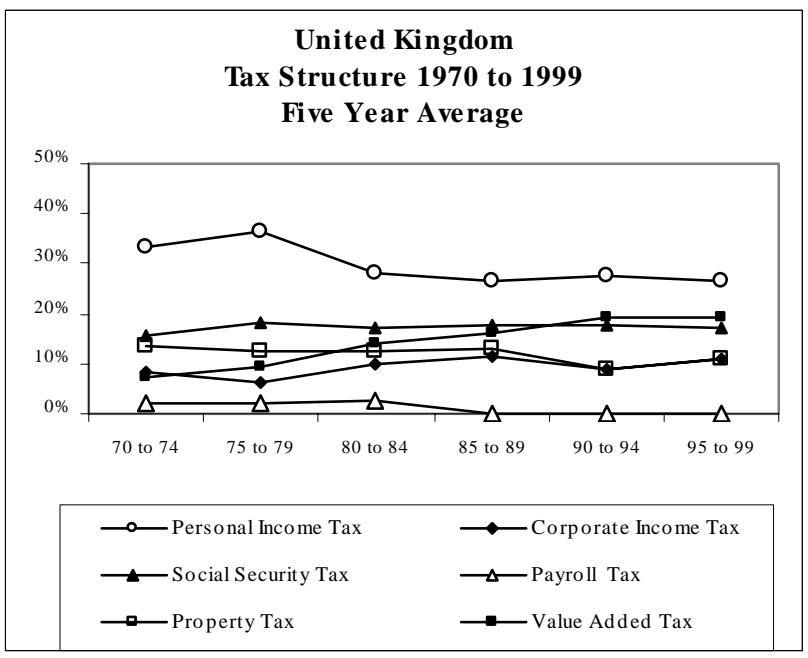


Appendix II - VAT GDP Ratio for Individual Sample OECD Countries
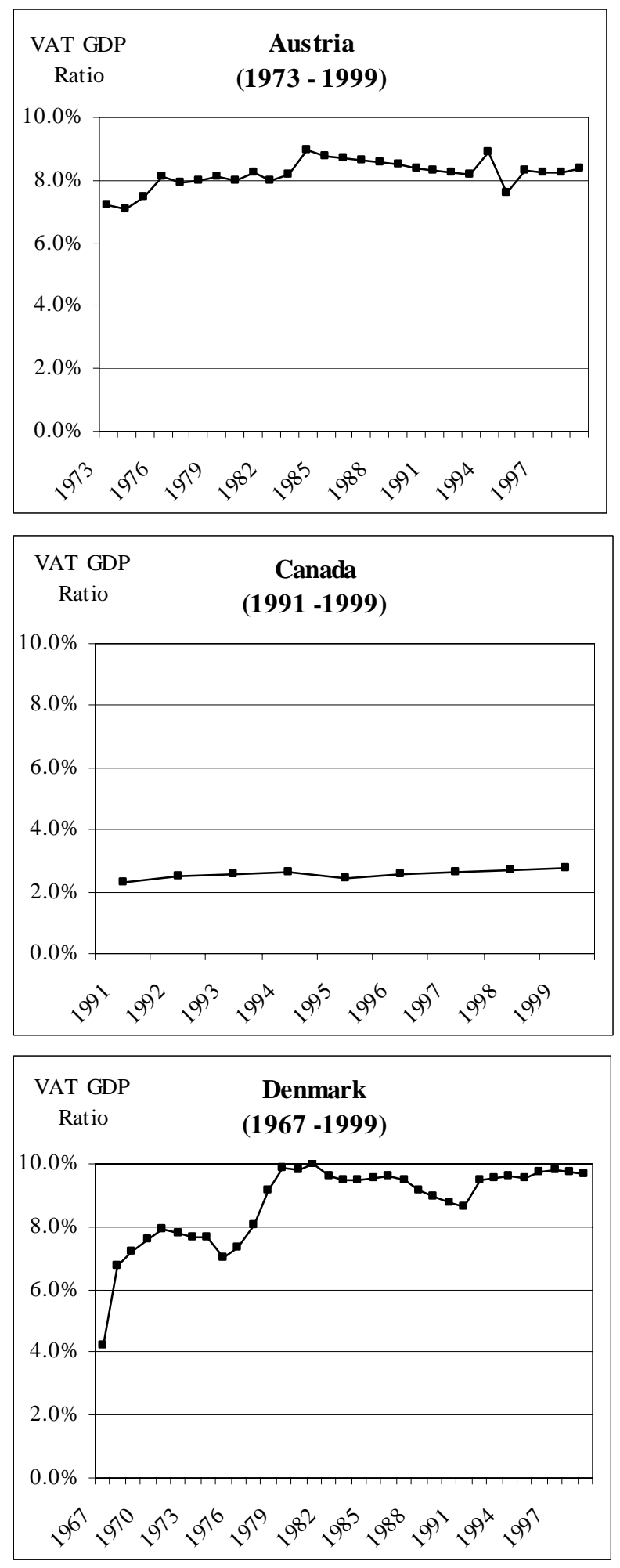
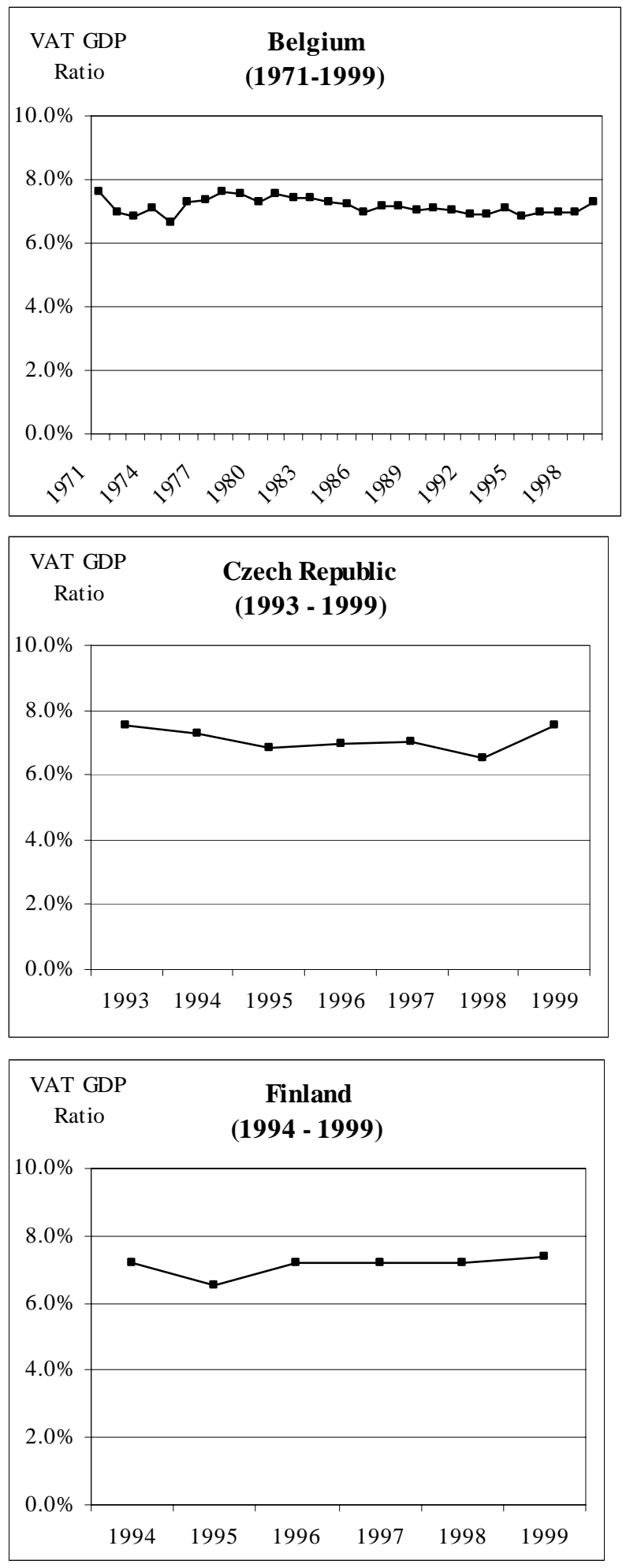

131 

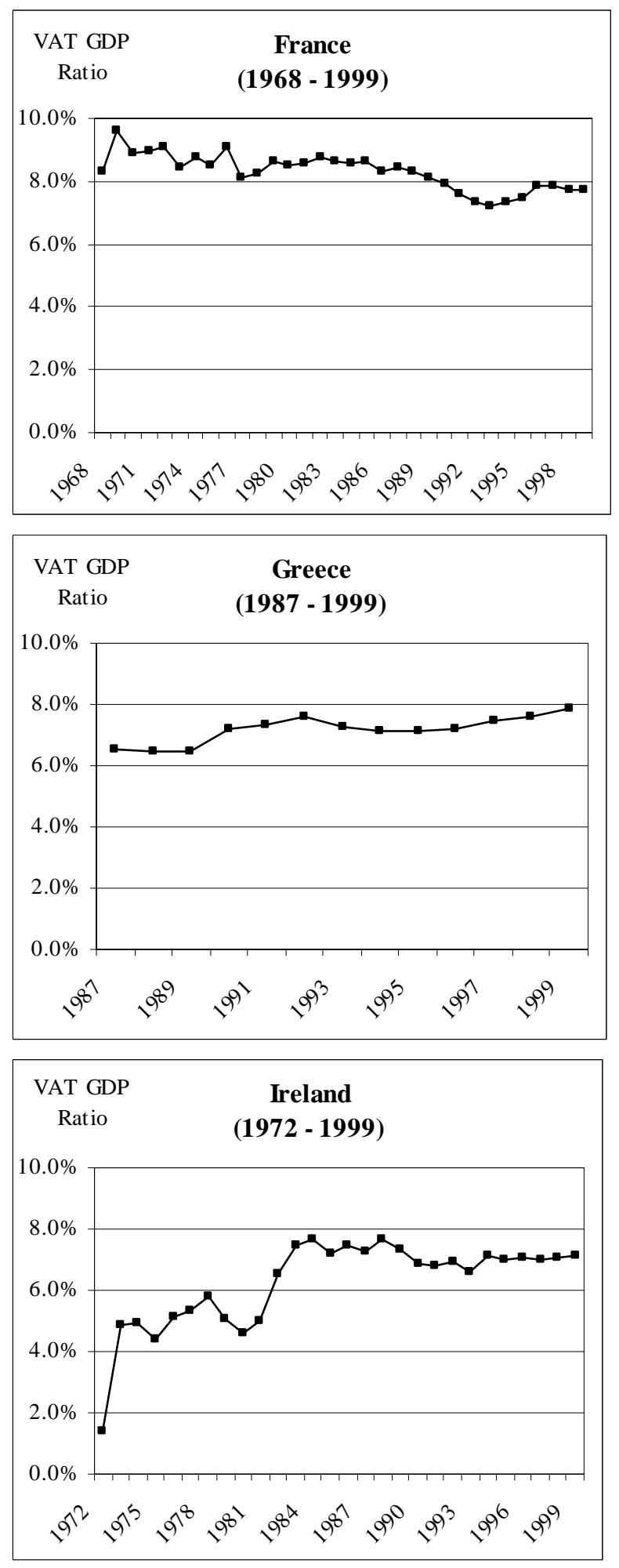
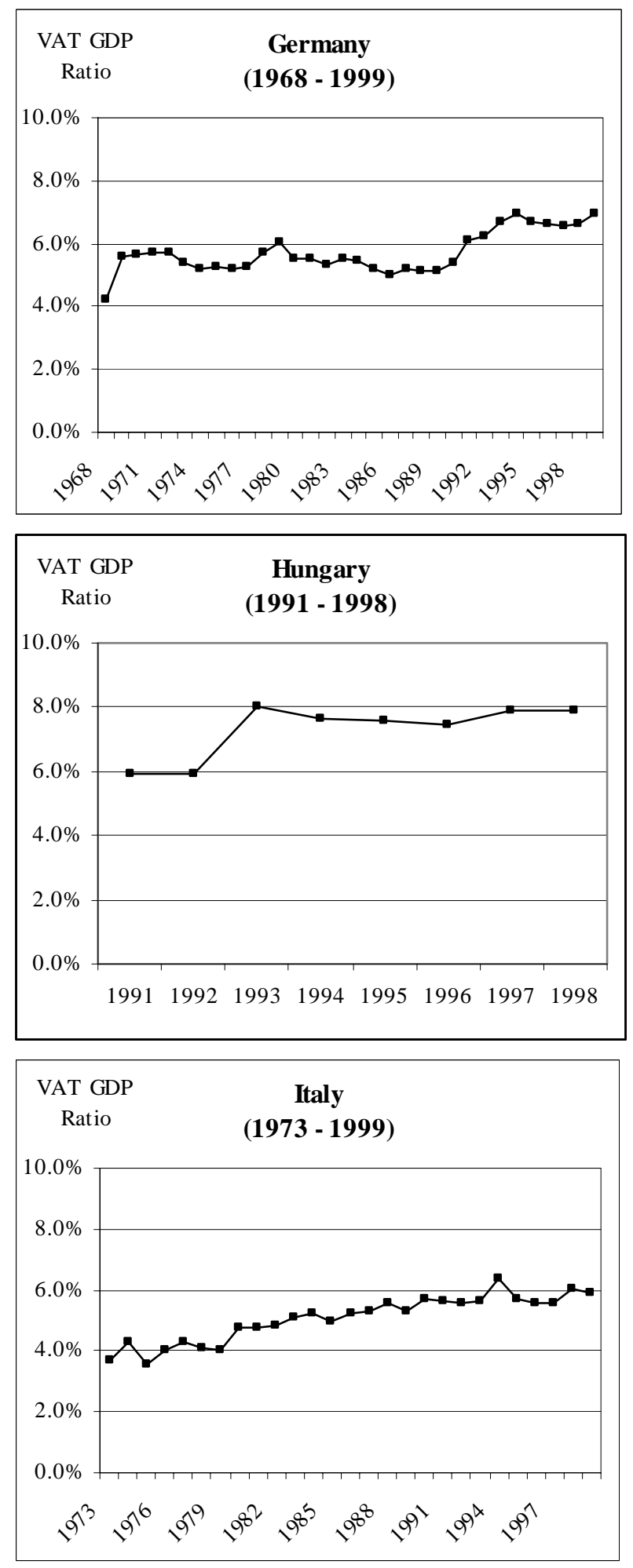

132 

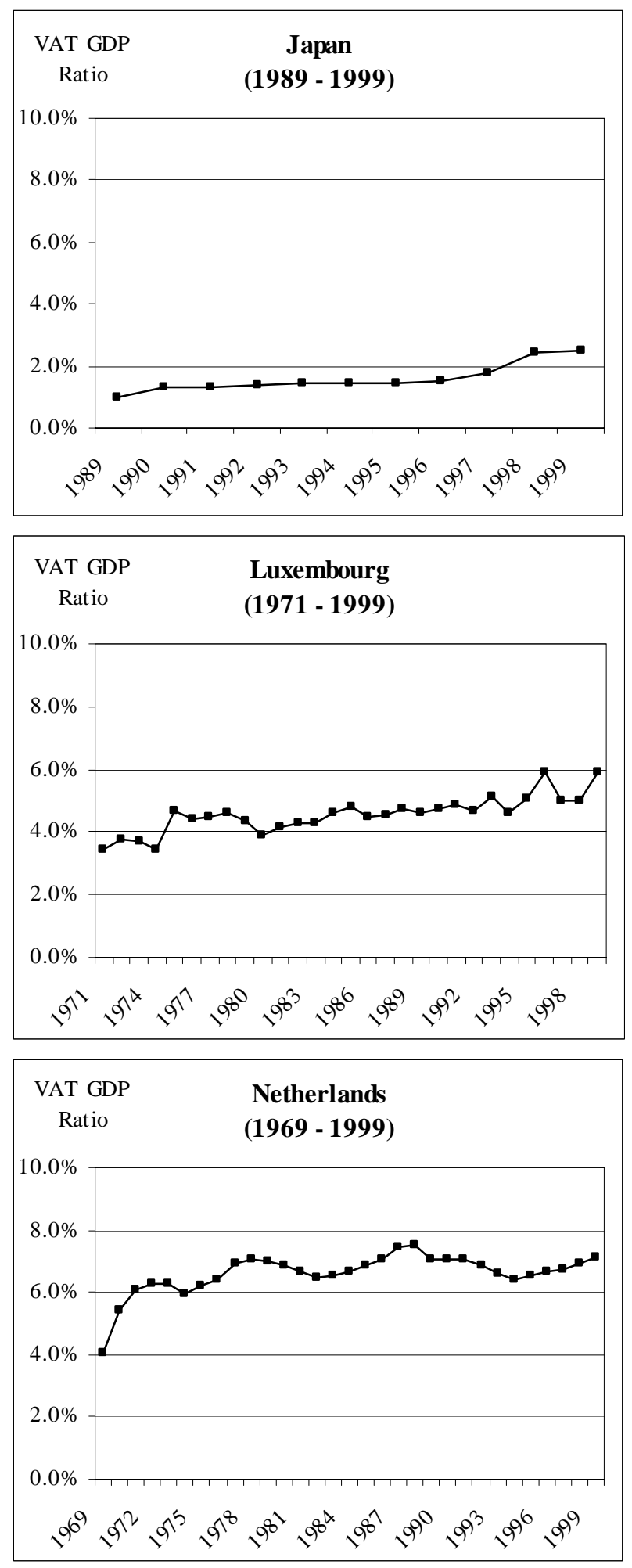
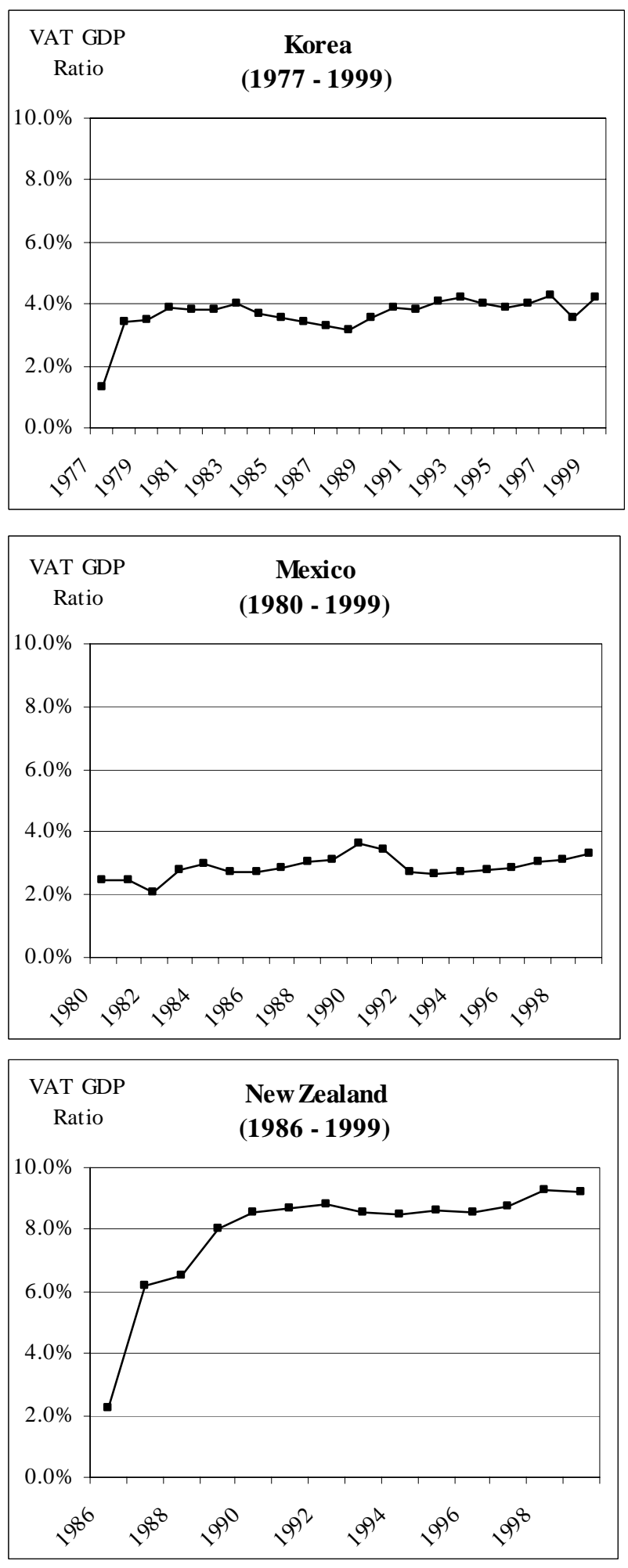

133 

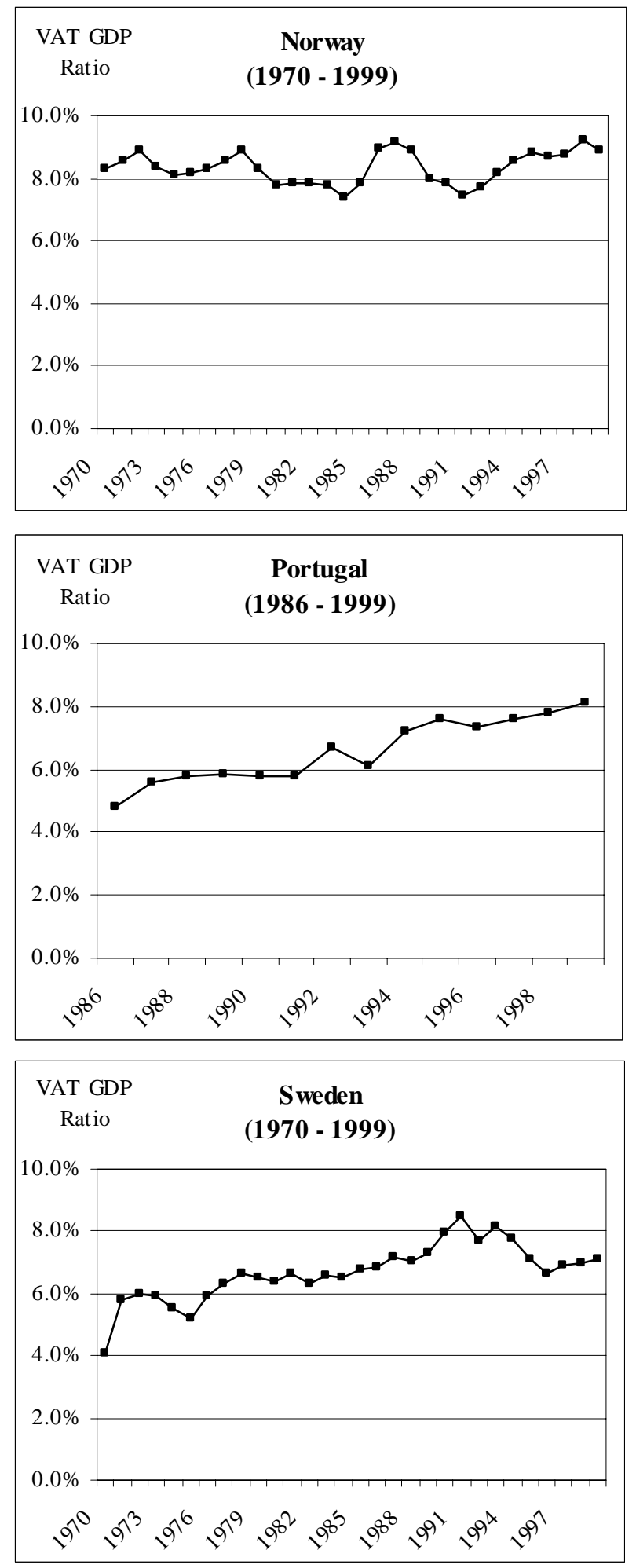
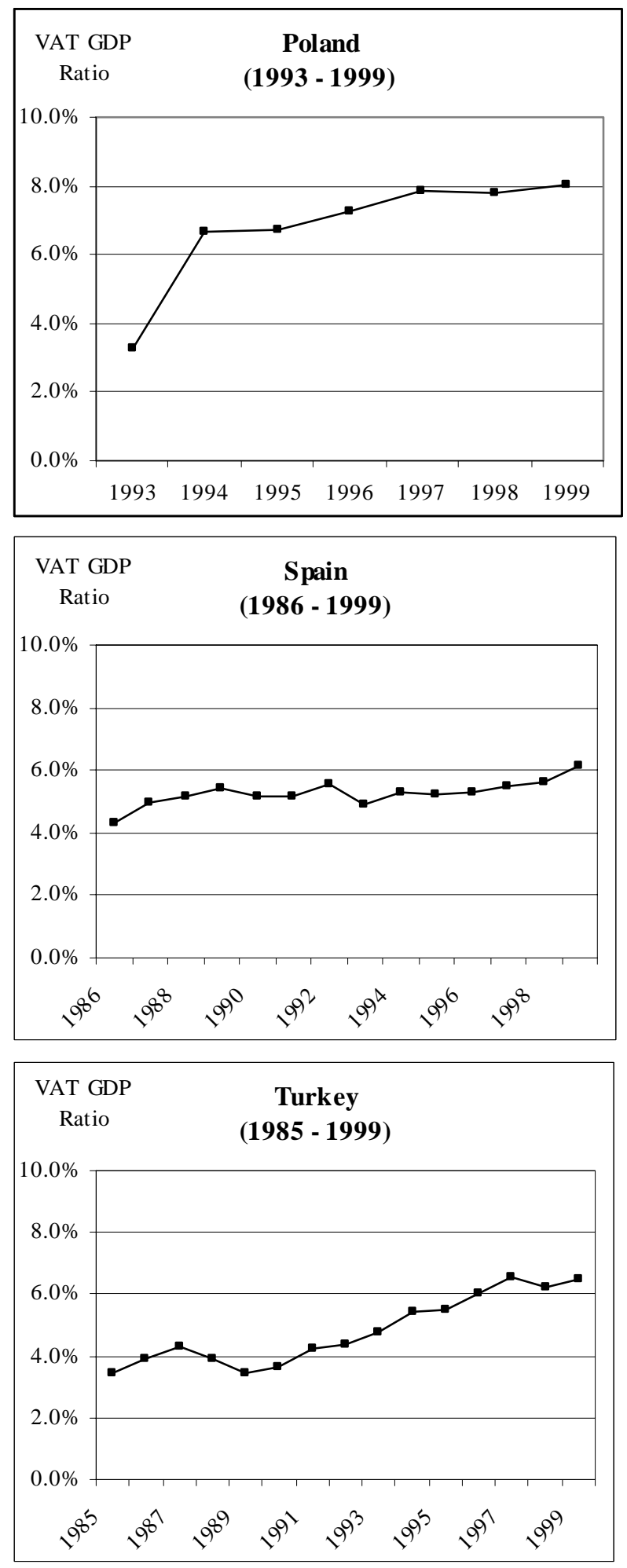

134 


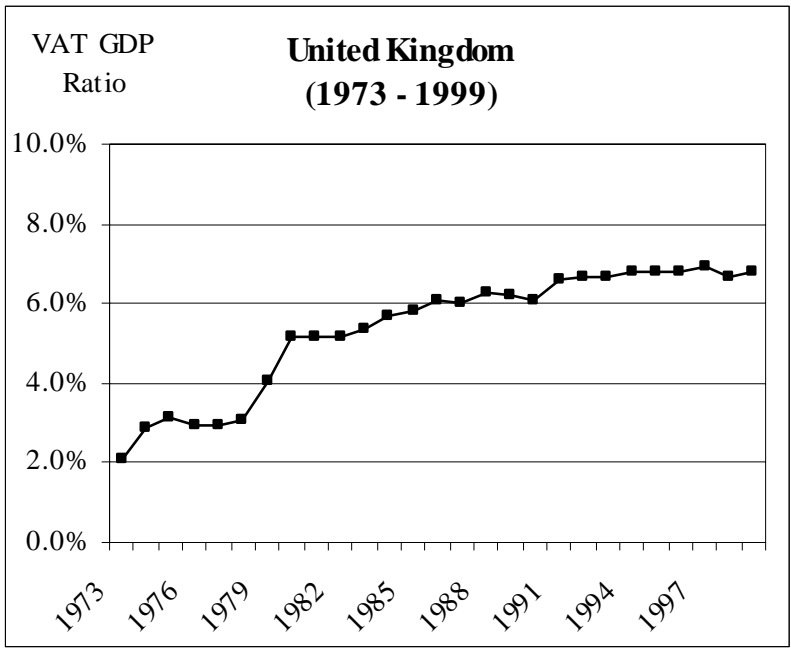


Appendix III - Data Description and Sources

(Note: all data are annual, and at the country level)

\begin{tabular}{|c|c|}
\hline Variable Name (source) & Description \\
\hline $\begin{array}{l}\text { Dependent Variable: } \\
\text { VAT Evasion Index }\end{array}$ & $1-\frac{\text { Actual VAT Revenue }(1)}{\text { Standard VAT Rate }(2) \times \text { Gross Value Added (3) }}$ \\
\hline Explanatory Variables: & \\
\hline$\overline{\text { One year lag of VAT ratio }}$ & 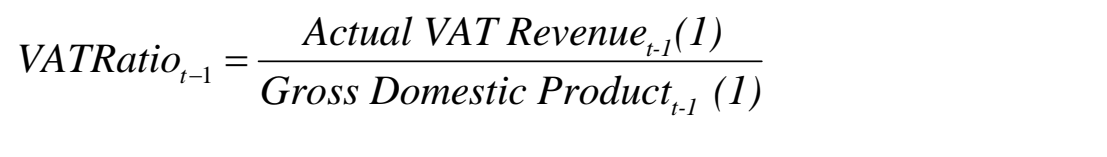 \\
\hline One year lag of VAT share & VATShare $_{t-1}=\frac{\text { Actual VAT Revenue }_{t-1}(1)}{\text { Total Tax Revenue }}$ \\
\hline Standard VAT rate (2) & The standard VAT rate. \\
\hline Multiple VAT rates (2) & Number of VAT rates including higher rates and reduced rates. \\
\hline$\frac{\text { Control Variables: }}{\text { Openness Index }}$ & OpennessIndex $=\frac{\text { Imports(3) }+ \text { Exports(3) }}{\text { Gross Domestic Product (1) }}$ \\
\hline Economically Active Population (3) & $\begin{array}{l}\text { Proportion of economically active population in total population } \\
\text { in a given year. }\end{array}$ \\
\hline Corruption in Government Index (4) & Corruption in government \\
\hline VAT Experience Dummy & Dummy variable, which takes the values from 0 to 32 . \\
\hline
\end{tabular}

1. OECD, 2001. Revenue Statistics 1965-2000.

2. European Commission, "VAT Rates Applied in the Member States of the European Community”, DOC/2908/20002-EN (2002) and Price Waterhouse, Corporate Taxes - a Worldwide Summary. Various years

3. World Bank, World Development Indicators 2003 CD-ROM, (2003).

4. IRIS Data 


\section{Appendix IV - Matrix of Correlation Coefficients}

\begin{tabular}{|c|c|c|c|c|c|c|}
\hline & $\begin{array}{c}\text { Log of VAT } \\
\text { Ratio }_{t-1}\end{array}$ & $\begin{array}{c}\text { Log of } \\
\text { VAT } \\
\text { Share }_{t-1}\end{array}$ & $\begin{array}{c}\text { Log of } \\
\text { Standard } \\
\text { VAT } \\
\text { Rate }\end{array}$ & $\begin{array}{c}\text { Log of } \\
\text { Number of } \\
\text { Multiple } \\
\text { VAT Rate }\end{array}$ & $\begin{array}{c}\text { Log of } \\
\text { Openness } \\
\text { Index }\end{array}$ & $\begin{array}{c}\text { Log of } \\
\text { Economically } \\
\text { Active } \\
\text { Population }\end{array}$ \\
\hline & (1) & $(2)$ & (3) & (4) & (5) & (6) \\
\hline Log of VAT Ratio $t_{t-1}$ & 1.000 & & & & & \\
\hline Log of VAT Share $\mathrm{t}_{-1}$ & & 1.000 & & & & \\
\hline $\begin{array}{l}\text { Log of Standard VAT } \\
\text { Rate }\end{array}$ & 0.811 & 0.594 & 1.000 & & & \\
\hline $\begin{array}{l}\text { Log of Number of } \\
\text { Multiple VAT Rate }\end{array}$ & 0.115 & 0.067 & 0.278 & 1.000 & & \\
\hline $\begin{array}{l}\text { Log of Openness } \\
\text { Index }\end{array}$ & 0.006 & -0.004 & 0.030 & -0.507 & 1.000 & \\
\hline $\begin{array}{l}\text { Log of Economically } \\
\text { Active Population }\end{array}$ & 0.548 & -0.146 & -0.179 & -0.206 & -0.137 & 1.000 \\
\hline
\end{tabular}


Appendix V - Results of Breusch-Pagan / Cook-Weisberg test for Heteroskedasticity

\begin{tabular}{|l|c|c|}
\hline Dependent Variables & $\begin{array}{c}\text { Without Openness Index } \\
\text { and Economically Active } \\
\text { Population }\end{array}$ & $\begin{array}{c}\text { With Openness Index and } \\
\text { Economically Active } \\
\text { Population }\end{array}$ \\
\hline Log VAT Ratio & $\chi^{2}(1)=17.54 * * *$ & $\chi^{2}(1)=6.07^{* *}$ \\
\hline Log VAT Share $\mathrm{t}_{-1}$ & $\chi^{2}(1)=280.5^{* * *}$ & $\chi^{2}(1)=213.43^{* * *}$ \\
\hline
\end{tabular}




\section{Appendix VIa - Sensitivity Analysis Results}

(VAT Ratio as independent variables)

\begin{tabular}{|c|c|c|c|}
\hline $\begin{array}{l}\text { VAT Evasion Index } \\
\text { Dependent Variable }\end{array}$ & $\begin{array}{c}\text { Full } \\
\text { Model }\end{array}$ & $\begin{array}{c}\text { Without } \\
\text { VAT Experience }\end{array}$ & $\begin{array}{c}\text { Without } \\
\text { Corruption in } \\
\text { Government Index }\end{array}$ \\
\hline & (1) & (2) & (3) \\
\hline Log of VAT Ratio Va-1 & $\begin{array}{l}-.421 * * * \\
(13.12)\end{array}$ & $\begin{array}{l}-.422 * * * \\
(13.22)\end{array}$ & $\begin{array}{c}-.396 * * * \\
(16.94)\end{array}$ \\
\hline $\begin{array}{l}\text { Log of Standard VAT } \\
\text { Rate }\end{array}$ & $\begin{array}{l}.443 * * * \\
(12.60)\end{array}$ & $\begin{array}{l}.453 * * * \\
(12.93)\end{array}$ & $\begin{array}{l}.423 * * * \\
(15.49)\end{array}$ \\
\hline $\begin{array}{l}\text { Log of Number of } \\
\text { Multiple VAT Rate }\end{array}$ & $\begin{array}{l}.012 \\
(0.71)\end{array}$ & $\begin{array}{c}.017 \\
(0.95)\end{array}$ & $\begin{array}{l}.030 * * \\
(2.16)\end{array}$ \\
\hline Log of Openness Index & $\begin{array}{l}-.004 \\
(0.69)\end{array}$ & $\begin{array}{l}-.003 \\
(0.53)\end{array}$ & $\begin{array}{l}-.001 \\
(0.14)\end{array}$ \\
\hline $\begin{array}{l}\text { Log of Economically } \\
\text { Active Population }\end{array}$ & $\begin{array}{l}-.036 \\
(0.16)\end{array}$ & $\begin{array}{l}-.011 \\
(0.05)\end{array}$ & $\begin{array}{l}.226 * \star \\
(2.47)\end{array}$ \\
\hline VAT Experience & $\begin{array}{c}.002 \\
(1.41)\end{array}$ & & $\begin{array}{c}.001 \\
(1.01)\end{array}$ \\
\hline $\begin{array}{l}\text { Log of Corruption in } \\
\text { Government Index }\end{array}$ & $\begin{array}{l}.019 * * \\
(2.44)\end{array}$ & $\begin{array}{l}.018 * * \\
(2.40)\end{array}$ & \\
\hline Constant & $\begin{array}{c}-1.020 * * * \\
(7.54)\end{array}$ & $\begin{array}{l}-.982 * * * \\
(7.48)\end{array}$ & $\begin{array}{l}-.885 * * * \\
(11.78)\end{array}$ \\
\hline $\mathrm{R}^{2}$ & 0.685 & 0.662 & 0.664 \\
\hline Sample size & 298 & 298 & 454 \\
\hline Model & Random Effect & Random Effect & Random Effect \\
\hline
\end{tabular}

Note: (1) Figures in parenthesis show z-statistics.

(2) $\quad * * *$ indicate 1 percent significance level. $* *$ indicate 5 percent significance level.

*indicate 10 percent significance level. 
Appendix VIb - Sensitivity Analysis Results (VAT Share as independent variables)

\begin{tabular}{|c|c|c|c|}
\hline $\begin{array}{l}\text { VAT Evasion Index } \\
\text { Dependent Variable }\end{array}$ & $\begin{array}{l}\text { Full } \\
\text { Model }\end{array}$ & $\begin{array}{l}\text { Without VAT } \\
\text { Experience } \\
\text { Dummy }\end{array}$ & $\begin{array}{c}\text { Without } \\
\text { Corruption in } \\
\text { Government Index }\end{array}$ \\
\hline & (1) & $(2)$ & (3) \\
\hline Log of VAT Share ${ }_{t-1}$ & $\begin{array}{l}-.347 * * * \\
(10.11)\end{array}$ & $\begin{array}{l}-.345^{* * *} \\
(10.11)\end{array}$ & $\begin{array}{l}-.237^{* * *} \\
(9.74)\end{array}$ \\
\hline $\begin{array}{l}\text { Log of Standard VAT } \\
\text { Rate }\end{array}$ & $\begin{array}{l}.293^{* * *} \\
(9.06)\end{array}$ & $\begin{array}{l}.296 * * * \\
(9.34)\end{array}$ & $\begin{array}{l}.275 * \star * \\
(9.56)\end{array}$ \\
\hline $\begin{array}{l}\text { Log of Number of } \\
\text { Multiple VAT Rate }\end{array}$ & $\begin{array}{l}.021 \\
(1.07)\end{array}$ & $\begin{array}{c}.021 \\
(1.11)\end{array}$ & $\begin{array}{l}.022 \\
(1.41)\end{array}$ \\
\hline Log of Openness Index & $\begin{array}{c}-.004 \\
(0.64)\end{array}$ & $\begin{array}{c}-.004 \\
(0.60)\end{array}$ & $\begin{array}{c}-.001 \\
(0.10)\end{array}$ \\
\hline $\begin{array}{l}\text { Log of Economically } \\
\text { Active Population }\end{array}$ & $\begin{array}{l}-.627^{* *} \\
(2.44)\end{array}$ & $\begin{array}{l}-.624 * * \\
(2.43)\end{array}$ & $\begin{array}{c}.090 \\
(0.89)\end{array}$ \\
\hline VAT Experience & $\begin{array}{c}.001 \\
(0.45)\end{array}$ & & $\begin{array}{l}-.002 \\
(0.92)\end{array}$ \\
\hline $\begin{array}{l}\text { Corruption in } \\
\text { Government Index }\end{array}$ & $\begin{array}{l}.055 * * * \\
(6.05)\end{array}$ & $\begin{array}{l}.054 * * * \\
(6.02)\end{array}$ & \\
\hline Constant & $\begin{array}{c}-.999 * * * \\
(6.86)\end{array}$ & $\begin{array}{l}-.985 * * * \\
(6.91)\end{array}$ & $\begin{array}{c}-.462 * * * \\
(5.41)\end{array}$ \\
\hline $\mathrm{R}^{2}$ & $\odot .501$ & 0.498 & 0.181 \\
\hline Sample size & 298 & 298 & 454 \\
\hline Model & Random Effect & Random Effect & Random Effect \\
\hline
\end{tabular}

Note: (1) Figures in parenthesis show z-statistics.

(2) $\quad * * *$ indicate 1 percent significance level. $* *$ indicate 5 percent significance level. *indicate 10 percent significance level. 
Appendix VIIa - Sensitivity Analysis Results

(VAT Ratio as independent variable)

\begin{tabular}{|c|c|c|c|c|c|c|}
\hline $\begin{array}{l}\text { VAT Evasion Index } \\
\text { Dependent Variable }\end{array}$ & $\begin{array}{c}\text { Full } \\
\text { Model } \\
\text { (1) }\end{array}$ & $\begin{array}{c}\text { Without } \\
\text { Vat Ratio } \\
\\
\text { (2) }\end{array}$ & $\begin{array}{c}\text { Without } \\
\text { Standard } \\
\text { VAT Rate } \\
\\
\text { (3) } \\
\end{array}$ & $\begin{array}{c}\text { Without } \\
\text { Multiple VAT } \\
\text { Rate } \\
\text { (4) }\end{array}$ & $\begin{array}{c}\text { Without } \\
\text { Openness } \\
\text { Index } \\
\\
(5) \\
\end{array}$ & $\begin{array}{c}\text { Without } \\
\text { Economically } \\
\text { Active } \\
\text { Population } \\
\text { (6) }\end{array}$ \\
\hline Log of VAT Ratio ${ }_{t-1}$ & $\begin{array}{l}-.403^{* * *} \\
(17.25)\end{array}$ & & $\begin{array}{l}-.165^{* * *} \\
(7.54)\end{array}$ & $\begin{array}{l}-.415^{* * *} \\
(17.60)\end{array}$ & $\begin{array}{l}-.410 * * * \\
(17.52)\end{array}$ & $\begin{array}{l}-.399 * * * \\
(17.07)\end{array}$ \\
\hline $\begin{array}{l}\text { Log of Standard } \\
\text { VAT Rate }\end{array}$ & $\begin{array}{l}.432 * * * \\
(15.94)\end{array}$ & $\begin{array}{l}.105^{* * *} \\
(3.29)\end{array}$ & & $\begin{array}{l}.450 * * * \\
(16.70)\end{array}$ & $\begin{array}{l}.438 * * * \\
(16.18)\end{array}$ & $\begin{array}{l}.423 * * * \\
(15.74)\end{array}$ \\
\hline $\begin{array}{l}\text { Log of Number of } \\
\text { Multiple VAT Rate }\end{array}$ & $\begin{array}{l}.035^{*} \\
(2.49)\end{array}$ & $\begin{array}{c}.016 \\
(0.86)\end{array}$ & $\begin{array}{c}.016 \\
(1.01)\end{array}$ & & $\begin{array}{l}.036 * * * \\
(2.81)\end{array}$ & $\begin{array}{l}.032 * * \\
(2.31)\end{array}$ \\
\hline $\begin{array}{l}\text { Log of Openness } \\
\text { Index }\end{array}$ & $\begin{array}{c}.000 \\
(0.02)\end{array}$ & $\begin{array}{c}.000 \\
(0.04)\end{array}$ & $\begin{array}{l}-.001 \\
(0.15)\end{array}$ & $\begin{array}{l}-.004 \\
(1.01)\end{array}$ & & $\begin{array}{l}-.000 \\
(0.21)\end{array}$ \\
\hline $\begin{array}{l}\text { Log of Economically } \\
\text { Active Population }\end{array}$ & $\begin{array}{l}.234 * * \\
(2.54)\end{array}$ & $\begin{array}{c}.029 \\
(0.23)\end{array}$ & $\begin{array}{c}.053 \\
(0.52)\end{array}$ & $\begin{array}{l}.210 * * \\
(2.28)\end{array}$ & $\begin{array}{l}.234^{*} \\
(2.56)\end{array}$ & \\
\hline Constant & $\begin{array}{l}-.860 * * * \\
(13.65)\end{array}$ & $\begin{array}{l}-.377^{* * *} \\
(4.28)\end{array}$ & $\begin{array}{c}-1.030 * * * \\
(12.84)\end{array}$ & $\begin{array}{l}-.853^{* * *} \\
(13.66)\end{array}$ & $\begin{array}{c}-.873^{* * *} \\
(14.09)\end{array}$ & $\begin{array}{l}-.961 * * * \\
(18.85)\end{array}$ \\
\hline $\mathrm{R}^{2}$ & $\odot .658$ & 0.043 & $\odot .113$ & 0.644 & $\odot .660$ & 0.644 \\
\hline Sample size & 454 & 479 & 454 & 454 & 454 & 454 \\
\hline Model & $\begin{array}{l}\text { Random } \\
\text { Effects }\end{array}$ & $\begin{array}{l}\text { Random } \\
\text { Effects }\end{array}$ & $\begin{array}{l}\text { Random } \\
\text { Effects }\end{array}$ & $\begin{array}{l}\text { Random } \\
\text { Effects }\end{array}$ & $\begin{array}{c}\text { Random } \\
\text { Effects }\end{array}$ & $\begin{array}{c}\text { Random } \\
\text { Effects }\end{array}$ \\
\hline
\end{tabular}

Note: (1) Figures in parenthesis show z-statistics.

(2) ***indicate 1 percent significance level. **indicate 5 percent significance level. *indicate 10 percent significance level. 
Appendix VIIb - Sensitivity Analysis Results

(VAT Share as independent variable)

\begin{tabular}{|c|c|c|c|c|c|c|}
\hline $\begin{array}{l}\text { VAT Evasion Index } \\
\text { Dependent Variable }\end{array}$ & $\begin{array}{c}\text { Full } \\
\text { Model }\end{array}$ & $\begin{array}{c}\text { Without } \\
\text { Vat Ratio }\end{array}$ & $\begin{array}{c}\text { Without } \\
\text { Standard } \\
\text { VAT Rate }\end{array}$ & $\begin{array}{c}\text { Without } \\
\text { Multiple VAT } \\
\text { Rate }\end{array}$ & $\begin{array}{c}\text { Without } \\
\text { Openness } \\
\text { Index }\end{array}$ & $\begin{array}{c}\text { Without } \\
\text { Economically } \\
\text { Active } \\
\text { Population } \\
\end{array}$ \\
\hline & (1) & (2) & (3) & (4) & (5) & (6) \\
\hline Log of VAT Share ${ }_{t-1}$ & $\begin{array}{l}-.229 * * * \\
(10.01)\end{array}$ & & $\begin{aligned} &-.132 * * * \\
&(5.71)\end{aligned}$ & $\begin{array}{l}-.230 * * * \\
(10.05)\end{array}$ & $\begin{array}{l}-.229 * * * \\
(10.00)\end{array}$ & $\begin{array}{l}-.229 * * * \\
(10.00)\end{array}$ \\
\hline $\begin{array}{l}\text { Log of Standard } \\
\text { VAT Rate }\end{array}$ & $\begin{array}{l}.296 * * * \\
(9.93)\end{array}$ & $\begin{array}{l}105^{* * *} \\
(3.29)\end{array}$ & & $\begin{array}{l}.295 * * * \\
(9.92)\end{array}$ & $\begin{array}{l}.294 * * * \\
(9.92)\end{array}$ & $\begin{array}{l}.289 * * * \\
(9.77)\end{array}$ \\
\hline $\begin{array}{l}\text { Log of Number of } \\
\text { Multiple VAT Rate }\end{array}$ & $\begin{array}{c}.009 \\
(0.63)\end{array}$ & $\begin{array}{c}.016 \\
(0.86)\end{array}$ & $\begin{array}{c}.012 \\
(0.74)\end{array}$ & & $\begin{array}{c}.010 \\
(0.67)\end{array}$ & $\begin{array}{c}.009 \\
(0.58)\end{array}$ \\
\hline $\begin{array}{l}\text { Log of Openness } \\
\text { Index }\end{array}$ & $\begin{array}{c}.001 \\
(0.09)\end{array}$ & $\begin{array}{c}.000 \\
(0.04)\end{array}$ & $\begin{array}{l}-.001 \\
(0.15)\end{array}$ & $\begin{array}{l}-.0001 \\
(0.02)\end{array}$ & & $\begin{array}{c}.001 \\
(0.07)\end{array}$ \\
\hline $\begin{array}{l}\text { Log of Economically } \\
\text { Active Population }\end{array}$ & $\begin{array}{l}.162 * \\
(1.72)\end{array}$ & $\begin{array}{c}.029 \\
(\odot .23)\end{array}$ & $\begin{array}{c}.029 \\
(0.28)\end{array}$ & $\begin{array}{l}.158^{\star} \\
(1.67)\end{array}$ & $\begin{array}{l}.157^{*} \\
(1.66)\end{array}$ & \\
\hline Constant & $\begin{aligned} &-.400 * * * \\
&(5.29)\end{aligned}$ & $\begin{aligned}-.377^{* * *} & (4.28)\end{aligned}$ & $\begin{array}{l}-.813^{* * *} \\
(11.70)\end{array}$ & $\begin{array}{l}-.400 * * * \\
(5.33)\end{array}$ & $\begin{aligned} &-.409 * * * \\
&(5.63)\end{aligned}$ & $\begin{array}{l}-.480 * * * \\
(7.93)\end{array}$ \\
\hline $\mathrm{R}^{2}$ & 0.138 & 0.042 & $\odot . \odot 62$ & 0.132 & $\odot .141$ & $\odot .159$ \\
\hline Sample size & 454 & 479 & 454 & 454 & 454 & 454 \\
\hline Model & $\begin{array}{l}\text { Random } \\
\text { Effects }\end{array}$ & $\begin{array}{l}\text { Random } \\
\text { Effects }\end{array}$ & $\begin{array}{l}\text { Random } \\
\text { Effects }\end{array}$ & $\begin{array}{c}\text { Random } \\
\text { Effects }\end{array}$ & $\begin{array}{c}\text { Random } \\
\text { Effects }\end{array}$ & $\begin{array}{c}\text { Random } \\
\text { Effects }\end{array}$ \\
\hline
\end{tabular}

Note: (1) Figures in parenthesis show Z-statistics.

(2) ***indicate 1 percent significance level. **indicate 5 percent significance level. *indicate 10 percent significance level. 
Appendix VIII - Data Description and Sources (Note: all data are quarterly, and at the state level)

\begin{tabular}{|c|c|}
\hline Variable Name (source) & Description \\
\hline $\begin{array}{l}\text { Dependent Variable: } \\
\text { Total Tax Revenue Per Capita (1) }\end{array}$ & Total real tax revenue per capita \\
\hline $\begin{array}{l}\text { Explanatory Variables: } \\
\text { Personal Income (2) } \\
\text { Average Personal Income Tax Rate (3) } \\
\text { Average Corporate Income Tax Rate (3) } \\
\text { Sales Tax Rate (3) }\end{array}$ & $\begin{array}{l}\text { Real personal income of residents } \\
\text { Average personal income tax rate } \\
\text { Average corporate income tax rate } \\
\text { Sales tax rate in the state }\end{array}$ \\
\hline $\begin{array}{l}\text { Amnesty Variables: (all from 4): } \\
\text { Short-run effect of Amnesty } 1 \\
\text { Short-run effect of Amnesty } 2 \\
\text { Short-run effect of Amnesty } 3 \\
\text { Long-run effect of Amnesty } 1 \\
\text { Long-run effect of Amnesty } 2 \\
\text { Long-run effect of Amnesty } 3\end{array}$ & $\begin{array}{l}\text { Equals } 1 \text { during period of first amnesty, } 0 \text { before or after } \\
\text { Equals } 1 \text { during period of second amnesty, } 0 \text { before or after } \\
\text { Equals } 1 \text { during period of third amnesty, } 0 \text { before or after } \\
\text { Equals } 1 \text { during and after period of first amnesty, } 0 \text { before } \\
\text { Equals } 1 \text { during and after period of second amnesty, } 0 \text { before } \\
\text { Equals } 1 \text { during and after period of third amnesty, } 0 \text { before }\end{array}$ \\
\hline $\begin{array}{l}\text { Control Variables: } \\
\text { Unemployment Rate (5) } \\
\text { Budget Surplus or Shortfall (6) }\end{array}$ & $\begin{array}{l}\text { Unemployment rate } \\
\text { Budget surplus or shortfall for year, including intergovernmental } \\
\text { transfers, expressed as a percent of total tax revenue. }\end{array}$ \\
\hline
\end{tabular}

1. U.S. Census Bureau, State Government Finances, Washington, D.C.

2. U.S. Department of Commerce, Bureau of Economic Analysis, State and Local Personal Income, Washington, D. C.

3. Commerce Clearing House, Inc., State Tax Handbook, 1980 - 2003.

4. Federation of Tax Administrators, http://www.taxadmin.org/fta/rate/amnesty1.html

5. U.S. Department of Labor, Bureau of Labor Statistics, Demographics, Washington, D.C.

6. U.S. Census Bureau, State Government Finances, Washington, D.C., Book of the State and Statistical Abstract of the United States. 


\section{Appendix IX - Matrix of Correlation Coefficient}

\begin{tabular}{|c|c|c|c|c|c|c|c|c|c|c|c|c|c|c|}
\hline & 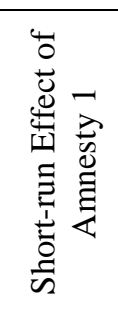 & 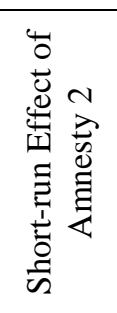 & 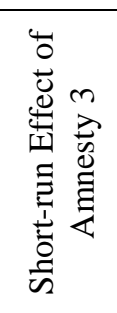 & 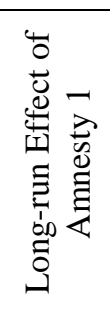 & 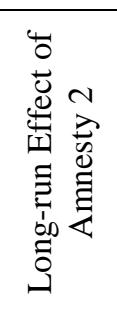 & 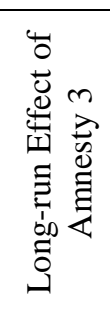 & 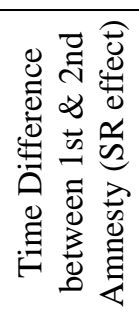 & 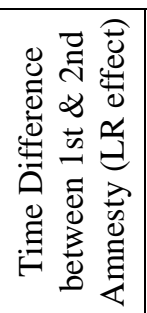 & 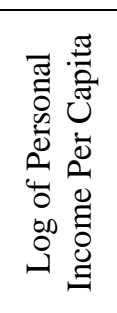 & 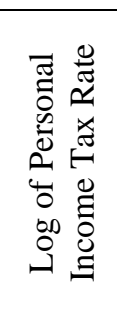 & 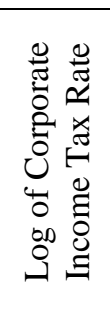 & 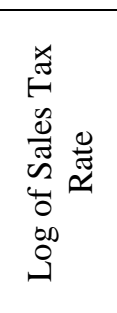 & 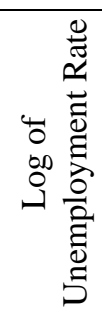 & 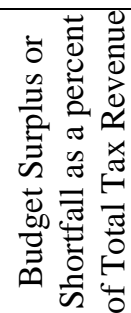 \\
\hline Short-run Effect of Amnesty 1 & 1 & & & & & & & & & & & & & \\
\hline Short-run Effect of Amnesty 2 & 0.005 & 1 & & & & & & & & & & & & \\
\hline Short-run Effect of Amnesty 3 & 0.002 & -0.001 & 1 & & & & & & & & & & & \\
\hline Long-run Effect of Amnesty 1 & -0.200 & -0.002 & -0.002 & 1 & & & & & & & & & & \\
\hline Long-run Effect of Amnesty 2 & 0.014 & -0.103 & 0.094 & -0.038 & 1 & & & & & & & & & \\
\hline Long-run Effect of Amnesty 3 & 0.000 & 0.050 & -0.452 & 0.007 & -0.429 & 1 & & & & & & & & \\
\hline $\begin{array}{l}\text { Time Difference between 1st } \\
\& \text { 2nd Amnesty (SR effect) }\end{array}$ & -0.004 & -0.869 & 0.024 & -0.001 & 0.183 & -0.068 & 1 & & & & & & & \\
\hline $\begin{array}{l}\text { Time Difference between 1st } \\
\text { \& 2nd Amnesty (LR effect) }\end{array}$ & -0.001 & 0.028 & -0.105 & 0.009 & -0.844 & 0.349 & -0.213 & 1 & & & & & & \\
\hline $\begin{array}{l}\text { Log of Personal Income Per } \\
\text { Capita }\end{array}$ & -0.002 & -0.018 & -0.061 & -0.067 & -0.038 & 0.050 & 0.036 & -0.060 & 1 & & & & & \\
\hline $\begin{array}{l}\text { Log of Personal Income Tax } \\
\text { Rate }\end{array}$ & 0.010 & 0.013 & 0.010 & -0.088 & 0.024 & 0.004 & 0.017 & -0.093 & 0.149 & 1 & & & & \\
\hline $\begin{array}{l}\text { Log of Corporate Income Tax } \\
\text { Rate }\end{array}$ & -0.019 & -0.005 & 0.018 & 0.000 & -0.048 & -0.016 & 0.007 & 0.030 & -0.347 & -0.162 & 1 & & & \\
\hline Log of Sales Tax Rate & 0.019 & -0.002 & -0.025 & 0.020 & 0.082 & 0.041 & 0.014 & -0.075 & 0.001 & -0.030 & -0.323 & 1 & & \\
\hline Log of Unemployment Rate & 0.031 & -0.007 & 0.011 & -0.231 & -0.102 & -0.022 & 0.011 & 0.013 & 0.322 & 0.260 & 0.052 & -0.256 & 1 & \\
\hline $\begin{array}{l}\text { Budget Surplus or Shortfall as } \\
\text { a percent of Total Tax } \\
\text { Revenue }\end{array}$ & -0.009 & -0.008 & 0.051 & -0.011 & 0.076 & -0.080 & 0.036 & -0.110 & 0.106 & 0.073 & 0.006 & 0.037 & 0.118 & 1 \\
\hline
\end{tabular}


Appendix X - Results of Breusch-Pagan / Cook-Weisberg test for Heteroskedasticity

\begin{tabular}{|l|c|c|c|c|}
\hline \multicolumn{1}{|c|}{$\begin{array}{c}\text { Dependent } \\
\text { Variables }\end{array}$} & $\begin{array}{c}\text { Without bsos } \\
\text { and sdif2 and } \\
\text { ldif2 }\end{array}$ & $\begin{array}{c}\text { With bsos but } \\
\text { without sdif2 } \\
\text { and ldif2 }\end{array}$ & $\begin{array}{c}\text { With sdif2 and } \\
\text { ldif2 but without } \\
\text { bsos }\end{array}$ & $\begin{array}{c}\text { With both bsos } \\
\text { and sdif2 and } \\
\text { ldif2 }\end{array}$ \\
\hline $\begin{array}{l}\text { Log of per capita } \\
\text { total tax revenue }\end{array}$ & $\chi^{2}=0.03$ & $\chi^{2}=0.10$ & $\chi^{2}=0.00$ & $\chi^{2}=0.17$ \\
\hline $\begin{array}{l}\text { Log of per capita } \\
\text { sales tax revenue }\end{array}$ & $\chi^{2}=0.36$ & $\chi^{2}=0.23$ & $\chi^{2}=0.48$ & $\chi^{2}=0.16$ \\
\hline $\begin{array}{l}\text { Log of per capita } \\
\text { personal income } \\
\text { tax revenue }\end{array}$ & $\chi^{2}=318.57^{* * *}$ & $\chi^{2}=331.05^{* * *}$ & $\chi^{2}=311.79^{* * *}$ & $\chi^{2}=324.68^{* * *}$ \\
\hline $\begin{array}{l}\text { Log of per capita } \\
\text { corporate income } \\
\text { tax revenue }\end{array}$ & $\chi^{2}=0.01$ & $\chi^{2}=0.03$ & $\chi^{2}=0.08$ & $\chi^{2}=0.00$ \\
\hline
\end{tabular}




\section{Appendix XIa - Regression Results for Per Capita Total Tax Revenue}

(Log of per capita total tax revenue as dependent variable without budget surplus or shortfall variable)

\begin{tabular}{|c|c|c|c|c|c|}
\hline Variable & $\begin{array}{c}\text { States with one } \\
\text { Amnesty }\end{array}$ & $\begin{array}{c}\text { States with one } \\
\text { \& two } \\
\text { Amnesties }\end{array}$ & $\begin{array}{l}\text { States with one, } \\
\text { two, \& three } \\
\text { Amnesties }\end{array}$ & $\begin{array}{c}\text { States with one } \\
\text { \& two } \\
\text { Amnesties }\end{array}$ & $\begin{array}{l}\text { States with one, } \\
\text { two, \& three } \\
\text { Amnesties }\end{array}$ \\
\hline & (1) & (2) & (3) & (4) & (5) \\
\hline $\begin{array}{l}\text { Short-run effect of } \\
\text { Amnesty1 }\end{array}$ & $\begin{array}{c}.070^{* * *} \\
(2.89)\end{array}$ & $\begin{array}{l}.056^{* * *} \\
(3.17) \\
\end{array}$ & $\begin{array}{l}.045^{* \star *} \\
(2.83)\end{array}$ & $\begin{array}{l}.056^{* * *} \\
(3.17)\end{array}$ & $\begin{array}{l}.045^{* * *} \\
(2.83)\end{array}$ \\
\hline $\begin{array}{l}\text { Short-run effect of } \\
\text { Amnesty2 }\end{array}$ & & $\begin{array}{l}-.046 \\
(1.41)\end{array}$ & $\begin{array}{l}-.013 \\
(0.54)\end{array}$ & $\begin{array}{l}-.030 \\
(0.46)\end{array}$ & $\begin{array}{l}.032 \\
(0.62)\end{array}$ \\
\hline $\begin{array}{l}\text { Short-run effect of } \\
\text { Amnesty3 }\end{array}$ & & & $\begin{array}{l}-.061 \\
(1.07)\end{array}$ & & $\begin{array}{l}-.064 \\
(1.13)\end{array}$ \\
\hline $\begin{array}{l}\text { Long-run effect of } \\
\text { Amnesty1 }\end{array}$ & $\begin{array}{l}-.062^{* * *} \\
(5.85)\end{array}$ & $\begin{array}{l}-.041^{* * *} \\
(4.83)\end{array}$ & $\begin{array}{l}-.033^{* * *} \\
(4.06)\end{array}$ & $\begin{array}{l}-.040^{* * *} \\
(4.70)\end{array}$ & $\begin{array}{l}-.033^{* * *} \\
(4.03)\end{array}$ \\
\hline $\begin{array}{l}\text { Long-run effect of } \\
\text { Amnesty2 }\end{array}$ & & $\begin{array}{l}-.025^{\star} \\
(1.81)\end{array}$ & $\begin{array}{c}-.039 * * * \\
(3.51)\end{array}$ & $\begin{array}{l}-.094^{* * *} \\
(3.40)\end{array}$ & $\begin{array}{l}-.061^{* *} \\
(2.49)\end{array}$ \\
\hline $\begin{array}{l}\text { Long-run effect of } \\
\text { Amnesty3 }\end{array}$ & & & $\begin{array}{l}-.039 \\
(1.36) \\
\end{array}$ & & $\begin{array}{l}-.031 \\
(1.06) \\
\end{array}$ \\
\hline $\begin{array}{l}\text { Time difference } \\
\text { between } 1^{\text {st }} \& 2^{\text {nd }} \\
\text { Amnesty (SR Effect) }\end{array}$ & & & & $\begin{array}{l}-.004 \\
(\odot .87)\end{array}$ & $\begin{array}{l}-.005 \\
(1.15)\end{array}$ \\
\hline $\begin{array}{l}\text { Time difference } \\
\text { between } 1^{\text {st }} \& 2^{\text {nd }} \\
\text { Amnesty (LR Effect) }\end{array}$ & & & & $\begin{array}{c}.008^{* \star *} \\
(2.89)\end{array}$ & $\begin{array}{c}.002 \\
(1.04)\end{array}$ \\
\hline $\begin{array}{l}\text { Log of Personal } \\
\text { Income }\end{array}$ & $\begin{array}{l}.886^{* * *} \\
(10.29)\end{array}$ & $\begin{array}{l}.938^{* \star *} \\
(13.84)\end{array}$ & $\begin{array}{l}.921^{* \star *} \\
(15.23)\end{array}$ & $\begin{array}{l}.920^{* \star *} \\
(13.49)\end{array}$ & $\begin{array}{l}.920^{\star * \star} \\
(15.13)\end{array}$ \\
\hline $\begin{array}{l}\text { Log of Personal } \\
\text { Income Tax Rate }\end{array}$ & $\begin{array}{l}.0005 \\
(0.04)\end{array}$ & $\begin{array}{l}-.023^{* *} \\
(2.05)\end{array}$ & $\begin{array}{l}-.003 \\
(0.26)\end{array}$ & $\begin{array}{l}-.024^{* *} \\
(2.11)\end{array}$ & $\begin{array}{l}-.003 \\
(0.24)\end{array}$ \\
\hline $\begin{array}{l}\text { Log of Corporate } \\
\text { Income Tax Rate }\end{array}$ & $\begin{array}{l}.067^{\star} \\
(1.94)\end{array}$ & $\begin{array}{l}.009 \\
(0.38)\end{array}$ & $\begin{array}{l}.038^{*} \\
(1.76)\end{array}$ & $\begin{array}{l}.006 \\
(0.25)\end{array}$ & $\begin{array}{l}.036^{\star} \\
(1.68)\end{array}$ \\
\hline Log of Sales Tax Rate & $\begin{array}{l}.187^{\star \star \star} \\
(5.57)\end{array}$ & $\begin{array}{l}.138^{* * *} \\
(6.08)\end{array}$ & $\begin{array}{l}.131^{\star * *} \\
(6.11)\end{array}$ & $\begin{array}{l}.137^{\star \star *} \\
(6.05)\end{array}$ & $\begin{array}{l}.131^{\star \star *} \\
(6.12)\end{array}$ \\
\hline $\begin{array}{l}\text { Log of unemployment } \\
\text { rate }\end{array}$ & $\begin{array}{c}-.056^{* * *} \\
(3.10)\end{array}$ & $\begin{array}{c}-.061^{* * *} \\
(4.56)\end{array}$ & $\begin{array}{l}-.071^{* * \star} \\
(5.90)\end{array}$ & $\begin{array}{c}-.062^{* \star *} \\
(4.65)\end{array}$ & $\begin{array}{c}-.072^{\star \star \star} \\
(5.95)\end{array}$ \\
\hline Constant & $\begin{array}{l}-2.031^{* *} \\
(2.25)\end{array}$ & $\begin{array}{c}-2.961^{* * *} \\
(4.31)\end{array}$ & $\begin{array}{c}-2.674^{\star * *} \\
(4.37)\end{array}$ & $\begin{array}{c}-2.789^{* * *} \\
(4.04)\end{array}$ & $\begin{array}{c}-2.662^{\star * *} \\
(4.33)\end{array}$ \\
\hline $\mathrm{R}^{2}$ & 0.635 & 0.546 & 0.603 & 0.549 & 0.603 \\
\hline No of Observations & 1648 & 2917 & 3418 & 2917 & 3418 \\
\hline Model & Random Effects & Random Effects & Random Effects & Random Effects & Random Effects \\
\hline
\end{tabular}

Notes: Figures in parenthesis are absolute z-statistics, ${ }^{* * *}$ indicates 1 percent significance level, ${ }^{* *}$ indicates 5 percent significance level, *indicates 10 percent significance level. 


\section{Appendix XIb - Regression Results for Per Capita Total Tax Revenue}

(Log of per capita total tax revenue as dependent variable with budget surplus or shortfall variable)

\begin{tabular}{|c|c|c|c|c|c|}
\hline Variable & $\begin{array}{c}\text { States with one } \\
\text { Amnesty }\end{array}$ & $\begin{array}{c}\text { States with one } \\
\text { \& two } \\
\text { Amnesties }\end{array}$ & $\begin{array}{l}\text { States with one, } \\
\text { two, \& three } \\
\text { Amnesties }\end{array}$ & $\begin{array}{c}\text { States with one } \\
\text { \& two } \\
\text { Amnesties }\end{array}$ & $\begin{array}{c}\text { States with one, } \\
\text { two, \& three } \\
\text { Amnesties }\end{array}$ \\
\hline & (1) & (2) & (3) & (4) & (5) \\
\hline $\begin{array}{l}\text { Short-run effect of } \\
\text { Amnesty1 }\end{array}$ & $\begin{array}{l}.069^{* * *} \\
(2.85)\end{array}$ & $\begin{array}{l}.057^{* * *} \\
(3.23)\end{array}$ & $\begin{array}{l}.046^{* * *} \\
(2.84)\end{array}$ & $\begin{array}{l}.057^{* * *} \\
(3.23)\end{array}$ & $\begin{array}{l}.045^{* * *} \\
(2.85)\end{array}$ \\
\hline $\begin{array}{l}\text { Short-run effect of } \\
\text { Amnesty2 }\end{array}$ & & $\begin{array}{l}-.040 \\
(1.24)\end{array}$ & $\begin{array}{l}-.010 \\
(0.42)\end{array}$ & $\begin{array}{l}-.037 \\
(0.58)\end{array}$ & $\begin{array}{l}.029 \\
(0.56)\end{array}$ \\
\hline $\begin{array}{l}\text { Short-run effect of } \\
\text { Amnesty3 }\end{array}$ & & & $\begin{array}{l}-.048 \\
(0.85)\end{array}$ & & $\begin{array}{l}-.052 \\
(0.92)\end{array}$ \\
\hline $\begin{array}{l}\text { Long-run effect of } \\
\text { Amnesty1 }\end{array}$ & $\begin{array}{c}-.061^{* * *} \\
(5.85)\end{array}$ & $\begin{aligned}- & .042^{* * *} \\
& (4.95)\end{aligned}$ & $\begin{array}{c}-.033^{* * *} \\
(4.13)\end{array}$ & $\begin{array}{c}-.041^{* * *} \\
(4.82)\end{array}$ & $\begin{array}{l}-.033^{* * *} \\
(4.09)\end{array}$ \\
\hline $\begin{array}{l}\text { Long-run effect of } \\
\text { Amnesty2 }\end{array}$ & & $\begin{array}{l}-.026^{*} \\
(1.90)\end{array}$ & $\begin{aligned}-.042^{* * *} & (3.77)\end{aligned}$ & $\begin{aligned}- & .105^{* * *} \\
& (3.75)\end{aligned}$ & $\begin{aligned}- & .066^{* * *} \\
& (2.78)\end{aligned}$ \\
\hline $\begin{array}{l}\text { Long-run effect of } \\
\text { Amnesty3 }\end{array}$ & & & $\begin{array}{l}-.051^{*} \\
(1.75)\end{array}$ & & $\begin{array}{l}-.042 \\
(1.40)\end{array}$ \\
\hline $\begin{array}{l}\text { Time difference } \\
\text { between } 1^{\text {st }} \& 2^{\text {nd }} \\
\text { Amnesty (SR Effect) }\end{array}$ & & & & $\begin{array}{l}-.004 \\
(0.71)\end{array}$ & $\begin{array}{l}-.004 \\
(1.06)\end{array}$ \\
\hline $\begin{array}{l}\text { Time difference } \\
\text { between } 1^{\text {st }} \& 2^{\text {nd }} \\
\text { Amnesty (LR Effect) }\end{array}$ & & & & $\begin{array}{l}.008^{* \star *} \\
(3.24)\end{array}$ & $\begin{array}{l}.003 \\
(1.24)\end{array}$ \\
\hline $\begin{array}{l}\text { Log of Personal } \\
\text { Income }\end{array}$ & $\begin{array}{l}.890^{\star \star *} \\
(10.31)\end{array}$ & $\begin{array}{l}.947^{\star \star \star} \\
(13.96)\end{array}$ & $\begin{array}{l}.927^{\star \star \star} \\
(15.35)\end{array}$ & $\begin{array}{l}.928^{\star \star \star} \\
(13.58)\end{array}$ & $\begin{array}{l}.928^{* \star \star} \\
(15.21)\end{array}$ \\
\hline $\begin{array}{l}\text { Log of Personal } \\
\text { Income Tax Rate }\end{array}$ & $\begin{array}{c}-.002 \\
(0.17)\end{array}$ & $\begin{array}{l}-.024^{* *} \\
(2.07)\end{array}$ & $\begin{array}{l}-.003 \\
(0.31)\end{array}$ & $\begin{array}{l}-.025^{\star \star} \\
(2.15)\end{array}$ & $\begin{array}{l}-.003 \\
(0.31)\end{array}$ \\
\hline $\begin{array}{l}\text { Log of Corporate } \\
\text { Income Tax Rate }\end{array}$ & $\begin{array}{l}.072^{* *} \\
(2.09)\end{array}$ & $\begin{array}{l}.008 \\
(0.33)\end{array}$ & $\begin{array}{l}.036^{*} \\
(1.66)\end{array}$ & $\begin{array}{l}.004 \\
(0.17)\end{array}$ & $\begin{array}{l}.034 \\
(1.58)\end{array}$ \\
\hline Log of Sales Tax Rate & $\begin{array}{l}.170^{\star \star \star} \\
(4.96)\end{array}$ & $\begin{array}{l}.136^{\star \star \star} \\
(5.95)\end{array}$ & $\begin{array}{l}.129 * \star \star \\
(6.0 \odot)\end{array}$ & $\begin{array}{l}.134^{\star \star \star} \\
(5.91)\end{array}$ & $\begin{array}{l}.129 * \star \star \\
(6.00)\end{array}$ \\
\hline $\begin{array}{l}\text { Log of unemployment } \\
\text { rate }\end{array}$ & $\begin{array}{l}-.046^{* \star} \\
(2.52)\end{array}$ & $\begin{array}{c}-.050^{* * *} \\
(3.68)\end{array}$ & $\begin{array}{c}-.060^{* \star \star} \\
(4.92)\end{array}$ & $\begin{array}{c}-.051^{* * *} \\
(3.72)\end{array}$ & $\begin{array}{c}-.061^{* \star *} \\
(4.97)\end{array}$ \\
\hline $\begin{array}{l}\text { Budget Surplus or } \\
\text { Shortfall as a percent } \\
\text { of Total Tax Revenue }\end{array}$ & $\begin{array}{l}.070^{* *} \\
(2.46)\end{array}$ & $\begin{array}{l}.066^{\star * *} \\
(3.68)\end{array}$ & $\begin{array}{l}.067^{\star \star \star} \\
(3.98)\end{array}$ & $\begin{array}{c}.071^{* * *} \\
(3.94)\end{array}$ & $\begin{array}{l}.068^{* * *} \\
(4.01)\end{array}$ \\
\hline Constant & $\begin{array}{c}-2.118^{* *} \\
(2.34)\end{array}$ & $\begin{array}{c}-3.072^{* * *} \\
(4.47)\end{array}$ & $\begin{array}{c}-2.746^{* * *} \\
(4.50)\end{array}$ & $\begin{array}{c}-2.891^{* * *} \\
(4.18)\end{array}$ & $\begin{array}{c}-2.764^{* * *} \\
(4.48)\end{array}$ \\
\hline $\mathrm{R}^{2}$ & 0.633 & 0.546 & 0.603 & 0.550 & 0.603 \\
\hline No of Observations & 1648 & 2917 & 3418 & 2917 & 3418 \\
\hline Model & Random Effects & Random Effects & Random Effects & Random Effects & Random Effects \\
\hline
\end{tabular}

Notes: Figures in parenthesis are absolute z-statistics, ${ }^{* * *}$ indicates 1 percent significance level, ${ }^{* *}$ indicates 5 percent significance level, *indicates 10 percent significance level. 


\section{Appendix XIIa - Regression Results for Per Capita Sales Tax Revenue}

(Log of per capita sales tax revenue as dependent variable and without budget surplus and shortfall variable)

\begin{tabular}{|c|c|c|c|c|c|}
\hline Variable & $\begin{array}{l}\text { States with one } \\
\text { Amnesty }\end{array}$ & $\begin{array}{c}\text { States with one } \\
\text { \& two } \\
\text { Amnesties }\end{array}$ & $\begin{array}{l}\text { States with one, } \\
\text { two, \& three } \\
\text { Amnesties }\end{array}$ & $\begin{array}{c}\text { States with one } \\
\text { \& two } \\
\text { Amnesties }\end{array}$ & $\begin{array}{l}\text { States with one, } \\
\text { two, \& three } \\
\text { Amnesties }\end{array}$ \\
\hline & (1) & (2) & (3) & (4) & (5) \\
\hline $\begin{array}{l}\text { Short-run effect of } \\
\text { Amnesty1 }\end{array}$ & $\begin{array}{l}.058 \\
(1.57) \\
\end{array}$ & $\begin{array}{l}.050^{*} \\
(1.94) \\
\end{array}$ & $\begin{array}{l}.041^{*} \\
(1.87) \\
\end{array}$ & $\begin{array}{l}.050^{*} \\
(1.94) \\
\end{array}$ & $\begin{array}{l}.042^{*} \\
(1.89) \\
\end{array}$ \\
\hline $\begin{array}{l}\text { Short-run effect of } \\
\text { Amnesty2 }\end{array}$ & & $\begin{array}{l}-.063 \\
(1.27) \\
\end{array}$ & $\begin{array}{c}-.038 \\
(1.08) \\
\end{array}$ & $\begin{array}{c}-.049 \\
(0.50) \\
\end{array}$ & $\begin{array}{r}-.033 \\
(0.44) \\
\end{array}$ \\
\hline $\begin{array}{l}\text { Short-run effect of } \\
\text { Amnesty3 }\end{array}$ & & & $\begin{array}{l}-.126 \\
(1.54)\end{array}$ & & $\begin{array}{l}-.123 \\
(1.50)\end{array}$ \\
\hline $\begin{array}{l}\text { Long-run effect of } \\
\text { Amnesty1 }\end{array}$ & $\begin{array}{l}-.051^{* * *} \\
(3.51)\end{array}$ & $\begin{array}{l}-.027^{* *} \\
(2.36)\end{array}$ & $\begin{array}{l}-.014 \\
(1.38)\end{array}$ & $\begin{array}{l}-.027^{* *} \\
(2.37)\end{array}$ & $\begin{array}{l}-.015 \\
(1.46)\end{array}$ \\
\hline $\begin{array}{l}\text { Long-run effect of } \\
\text { Amnesty2 }\end{array}$ & & $\begin{array}{l}.039^{\star} \\
(1.88)\end{array}$ & $\begin{array}{l}.030^{*} \\
(1.94)\end{array}$ & $\begin{array}{l}.052 \\
(1.24)\end{array}$ & $\begin{array}{l}.063^{*} \\
(1.89)\end{array}$ \\
\hline $\begin{array}{l}\text { Long-run effect of } \\
\text { Amnesty3 }\end{array}$ & & & $\begin{array}{l}.006 \\
(0.15)\end{array}$ & & $\begin{array}{l}-.004 \\
(0.10)\end{array}$ \\
\hline $\begin{array}{l}\text { Time difference } \\
\text { between } 1^{\text {st }} \& 2^{\text {nd }} \\
\text { Amnesty (SR Effect) }\end{array}$ & & & & $\begin{array}{l}-.0007 \\
(0.09)\end{array}$ & $\begin{array}{l}.0007 \\
(0.12)\end{array}$ \\
\hline $\begin{array}{l}\text { Time difference } \\
\text { between } 1^{\text {st }} \& 2^{\text {nd }} \\
\text { Amnesty (LR Effect) }\end{array}$ & & & & $\begin{array}{l}-.001 \\
(\odot .36)\end{array}$ & $\begin{array}{l}-.004 \\
(1.12)\end{array}$ \\
\hline $\begin{array}{l}\text { Log of Personal } \\
\text { Income }\end{array}$ & $\begin{array}{c}1.483^{* \star *} \\
(12.75)\end{array}$ & $\begin{array}{l}1.173^{\star \star \star} \\
(12.70)\end{array}$ & $\begin{array}{l}1.276^{\star \star \star} \\
(16.06)\end{array}$ & $\begin{array}{c}1.179^{* * *} \\
(12.69)\end{array}$ & $\begin{array}{c}1.288^{\star * *} \\
(16.15)\end{array}$ \\
\hline Log of Sales Tax Rate & $\begin{array}{l}.433^{* * *} \\
(10.42)\end{array}$ & $\begin{array}{l}.502^{* * *} \\
(16.62)\end{array}$ & $\begin{array}{l}.490^{* \star *} \\
(18.16)\end{array}$ & $\begin{array}{l}.502^{\star \star \star} \\
(16.62)\end{array}$ & $\begin{array}{l}.493^{* * *} \\
(18.21)\end{array}$ \\
\hline $\begin{array}{l}\text { Log of unemployment } \\
\text { rate }\end{array}$ & $\begin{array}{l}-.029 \\
(1.08)\end{array}$ & $\begin{array}{l}-.077^{\star \star \star} \\
(3.97)\end{array}$ & $\begin{array}{l}-.070^{\star \star \star} \\
(4.23)\end{array}$ & $\begin{array}{l}-.076^{* \star *} \\
(3.95)\end{array}$ & $\begin{array}{l}-.068 \\
(4.18)\end{array}$ \\
\hline Constant & $\begin{array}{c}-8.711^{* \star *} \\
(7.22)\end{array}$ & $\begin{array}{c}-5.344^{* \star *} \\
(5.68)\end{array}$ & $\begin{array}{c}-6.482^{\star \star \star} \\
(8.06)\end{array}$ & $\begin{array}{c}-5.400^{* * *} \\
(5.71)\end{array}$ & $\begin{array}{c}-6.599^{* * *} \\
(8.17)\end{array}$ \\
\hline $\mathrm{R}^{2}$ & 0.362 & 0.265 & 0.242 & 0.264 & 0.241 \\
\hline No of Observations & 2083 & 3351 & 3897 & 3351 & 3897 \\
\hline Model & Random Effects & Random Effects & Random Effects & Random Effects & Random Effects \\
\hline
\end{tabular}

Notes: Figures in parenthesis are absolute z-statistics, ***indicates 1 percent significance level, **indicates 5 percent significance level, *indicates 10 percent significance level. 


\section{Appendix XIIb - Regression Results for Per Capita Sales Tax Revenue}

(Log of per capita sales tax revenue as dependent variable and with budget surplus and shortfall variable)

\begin{tabular}{|c|c|c|c|c|c|}
\hline Variable & $\begin{array}{c}\text { States with one } \\
\text { Amnesty }\end{array}$ & $\begin{array}{c}\text { States with one } \\
\text { \& two } \\
\text { Amnesties } \\
\end{array}$ & $\begin{array}{c}\text { States with one, } \\
\text { two, \& three } \\
\text { Amnesties } \\
\end{array}$ & $\begin{array}{c}\text { States with one } \\
\text { \& two } \\
\text { Amnesties } \\
\end{array}$ & $\begin{array}{c}\text { States with one, } \\
\text { two, \& three } \\
\text { Amnesties } \\
\end{array}$ \\
\hline & (1) & (2) & (3) & (4) & (5) \\
\hline $\begin{array}{l}\text { Short-run effect of } \\
\text { Amnesty1 }\end{array}$ & $\begin{array}{c}.056 \\
(1.52)\end{array}$ & $\begin{array}{l}.050^{*} \\
(1.92)\end{array}$ & $\begin{array}{c}.041^{\star} \\
(1.85)\end{array}$ & $\begin{array}{c}.050^{*} \\
(1.92)\end{array}$ & $\begin{array}{l}.041^{*} \\
(1.86)\end{array}$ \\
\hline $\begin{array}{l}\text { Short-run effect of } \\
\text { Amnesty2 }\end{array}$ & & $\begin{array}{l}-.060 \\
(1.21)\end{array}$ & $\begin{array}{l}-.038 \\
(1.05)\end{array}$ & $\begin{array}{c}-.055 \\
(0.56) \\
\end{array}$ & $\begin{array}{l}-.035 \\
(0.47)\end{array}$ \\
\hline $\begin{array}{l}\text { Short-run effect of } \\
\text { Amnesty3 }\end{array}$ & & & $\begin{array}{c}-.120 \\
(1.46)\end{array}$ & & $\begin{array}{c}-.117 \\
(1.42)\end{array}$ \\
\hline $\begin{array}{l}\text { Long-run effect of } \\
\text { Amnesty1 }\end{array}$ & $\begin{array}{c}-.050 * * * \\
(3.44)\end{array}$ & $\begin{array}{l}-.027^{\star \star} \\
(2.33)\end{array}$ & $\begin{array}{c}-.014 \\
(1.33)\end{array}$ & $\begin{array}{l}-.027^{\star *} \\
(2.33)\end{array}$ & $\begin{array}{l}-.015 \\
(1.42)\end{array}$ \\
\hline $\begin{array}{l}\text { Long-run effect of } \\
\text { Amnesty2 }\end{array}$ & & $\begin{array}{l}.039^{\star} \\
(1.88)\end{array}$ & $\begin{array}{l}.030^{\star} \\
(1.90)\end{array}$ & $\begin{array}{c}.047 \\
(1.11)\end{array}$ & $\begin{array}{l}.061^{\star} \\
(1.81)\end{array}$ \\
\hline $\begin{array}{l}\text { Long-run effect of } \\
\text { Amnesty3 }\end{array}$ & & & $\begin{array}{c}.0002 \\
(0.01) \\
\end{array}$ & & $\begin{array}{l}-.009 \\
(0.22)\end{array}$ \\
\hline $\begin{array}{l}\text { Time difference } \\
\text { between } 1^{\text {st }} \& 2^{\text {nd }} \\
\text { Amnesty (SR Effect) }\end{array}$ & & & & $\begin{array}{l}-.0001 \\
(0.02)\end{array}$ & $\begin{array}{c}.001 \\
(0.15)\end{array}$ \\
\hline $\begin{array}{l}\text { Time difference } \\
\text { between } 1^{\text {st }} \& 2^{\text {nd }} \\
\text { Amnesty (LR Effect) }\end{array}$ & & & & $\begin{array}{l}-.001 \\
(0.21)\end{array}$ & $\begin{array}{c}-.003 \\
(1.05)\end{array}$ \\
\hline $\begin{array}{l}\text { Log of Personal } \\
\text { Income }\end{array}$ & $\begin{array}{c}1.477^{\star \star *} \\
(12.67)\end{array}$ & $\begin{array}{c}1.175^{\star \star *} \\
(12.70)\end{array}$ & $\begin{array}{c}1.282^{* \star \star} \\
(16.11)\end{array}$ & $\begin{array}{c}1.179^{* \star *} \\
(12.68)\end{array}$ & $\begin{array}{c}1.294^{\star \star \star} \\
(16.19)\end{array}$ \\
\hline Log of Sales Tax Rate & $\begin{array}{l}.424 * \star \star \\
(10.16)\end{array}$ & $\begin{array}{l}.499 * \star \star \\
(16.52)\end{array}$ & $\begin{array}{l}.488^{\star \star *} \\
(18.05)\end{array}$ & $\begin{array}{l}.499^{\star \star \star} \\
(16.52)\end{array}$ & $\begin{array}{l}.491^{\star \star \star} \\
(18.10)\end{array}$ \\
\hline $\begin{array}{l}\text { Log of unemployment } \\
\text { rate }\end{array}$ & $\begin{array}{l}-.025 \\
(0.92)\end{array}$ & $\begin{array}{l}-.071^{* * *} \\
(3.66)\end{array}$ & $\begin{array}{l}-.064^{\star \star *} \\
(3.88)\end{array}$ & $\begin{array}{l}-.071^{* \star *} \\
(3.65)\end{array}$ & $\begin{array}{c}-.064^{\star \star \star} \\
(3.84)\end{array}$ \\
\hline $\begin{array}{l}\text { Budget Surplus or } \\
\text { Shortfall as a percent } \\
\text { of Total Tax Revenue }\end{array}$ & $\begin{array}{l}.048^{\star \star} \\
(2.0 \odot)\end{array}$ & $\begin{array}{l}.042^{*} \\
(2.16)\end{array}$ & $\begin{array}{l}.036 * \star \\
(2.04)\end{array}$ & $\begin{array}{l}.041^{\star \star} \\
(2.14)\end{array}$ & $\begin{array}{l}.036 * \star \\
(2.00)\end{array}$ \\
\hline Constant & $\begin{array}{c}-8.667^{* \star *} \\
(7.17)\end{array}$ & $\begin{array}{c}-5.365^{\star * *} \\
(5.70)\end{array}$ & $\begin{array}{c}-6.550^{* * *} \\
(8.13)\end{array}$ & $\begin{array}{l}-5.411 \\
(5.72)\end{array}$ & $\begin{array}{c}-6.664^{* * *} \\
(8.24)\end{array}$ \\
\hline $\mathrm{R}^{2}$ & 0.362 & 0.266 & 0.243 & 0.266 & 0.242 \\
\hline No of Observations & 2083 & 3351 & 3897 & 3351 & 3897 \\
\hline Model & Random Effects & Random Effects & Random Effects & Random Effects & Random Effects \\
\hline
\end{tabular}

Notes: Figures in parenthesis are absolute z-statistics, ***indicates 1 percent significance level, **indicates 5 percent significance level, *indicates 10 percent significance level. 


\section{Appendix XIIIa - Regression Results for Per Capita Corporate Income Tax Revenue}

(Log of per capita corporate income tax revenue as dependent variable without budget surplus or shortfall variable)

\begin{tabular}{|c|c|c|c|c|c|}
\hline Variable & $\begin{array}{l}\text { States with one } \\
\text { Amnesty }\end{array}$ & $\begin{array}{c}\text { States with one } \\
\text { \& two } \\
\text { Amnesties }\end{array}$ & $\begin{array}{l}\text { States with one, } \\
\text { two, \& three } \\
\text { Amnesties }\end{array}$ & $\begin{array}{c}\text { States with one } \\
\text { \& two } \\
\text { Amnesties }\end{array}$ & $\begin{array}{l}\text { States with one, } \\
\text { two, \& three } \\
\text { Amnesties }\end{array}$ \\
\hline & (1) & (2) & (3) & (4) & (5) \\
\hline $\begin{array}{l}\text { Short-run effect of } \\
\text { Amnesty1 }\end{array}$ & $\begin{array}{l}.307^{* \star} \\
(2.18) \\
\end{array}$ & $\begin{array}{l}.133 \\
(1.50) \\
\end{array}$ & $\begin{array}{l}.135^{*} \\
(1.79) \\
\end{array}$ & $\begin{array}{l}.132 \\
(1.49) \\
\end{array}$ & $\begin{array}{l}.131^{\star} \\
(1.74) \\
\end{array}$ \\
\hline $\begin{array}{l}\text { Short-run effect of } \\
\text { Amnesty2 }\end{array}$ & & $\begin{array}{l}.157 \\
(0.96)\end{array}$ & $\begin{array}{l}.067 \\
(0.58)\end{array}$ & $\begin{array}{l}.341 \\
(1.10)\end{array}$ & $\begin{array}{l}.234 \\
(1.07)\end{array}$ \\
\hline $\begin{array}{l}\text { Short-run effect of } \\
\text { Amnesty3 }\end{array}$ & & & $\begin{array}{l}.311 \\
(1.10)\end{array}$ & & $\begin{array}{l}.280 \\
(0.99)\end{array}$ \\
\hline $\begin{array}{l}\text { Long-run effect of } \\
\text { Amnesty1 }\end{array}$ & $\begin{array}{l}-.104^{* \star} \\
(2.13)\end{array}$ & $\begin{array}{l}-.092^{* \star} \\
(2.51)\end{array}$ & $\begin{array}{l}-.093^{* * *} \\
(2.75)\end{array}$ & $\begin{array}{l}-.088^{\star *} \\
(2.39)\end{array}$ & $\begin{array}{l}-.088^{* \star *} \\
(2.59)\end{array}$ \\
\hline $\begin{array}{l}\text { Long-run effect of } \\
\text { Amnesty2 }\end{array}$ & & $\begin{array}{l}-.047 \\
(0.68)\end{array}$ & $\begin{array}{l}-.106^{* *} \\
(2.16)\end{array}$ & $\begin{array}{l}-.291^{* *} \\
(2.20)\end{array}$ & $\begin{array}{l}-.250^{* * *} \\
(2.89)\end{array}$ \\
\hline $\begin{array}{l}\text { Long-run effect of } \\
\text { Amnesty3 }\end{array}$ & & & $\begin{array}{c}-.462 * \star \star \\
(3.23)\end{array}$ & & $\begin{array}{c}-.413^{* * *} \\
(2.85)\end{array}$ \\
\hline $\begin{array}{l}\text { Time difference } \\
\text { between } 1^{\text {st }} \& 2^{\text {nd }} \\
\text { Amnesty (SR Effect) }\end{array}$ & & & & $\begin{array}{l}-.025 \\
(0.99)\end{array}$ & $\begin{array}{l}-.022 \\
(1.20)\end{array}$ \\
\hline $\begin{array}{l}\text { Time difference } \\
\text { between } 1^{\text {st }} \& 2^{\text {nd }} \\
\text { Amnesty (LR Effect) }\end{array}$ & & & & $\begin{array}{l}.028^{* \star} \\
(2.18)\end{array}$ & $\begin{array}{l}.019^{* *} \\
(2.02)\end{array}$ \\
\hline $\begin{array}{l}\text { Log of Personal } \\
\text { Income }\end{array}$ & $\begin{array}{l}2.253^{* \star *} \\
(9.14)\end{array}$ & $\begin{array}{c}1.819^{* \star *} \\
(8.87)\end{array}$ & $\begin{array}{c}1.550^{* * *} \\
(8.62)\end{array}$ & $\begin{array}{l}1.791^{* * *} \\
(8.71)\end{array}$ & $\begin{array}{l}1.550^{* * *} \\
(8.76)\end{array}$ \\
\hline $\begin{array}{l}\text { Log of Corporate } \\
\text { Income Tax Rate }\end{array}$ & $\begin{array}{l}.527^{* \star *} \\
(4.14) \\
\end{array}$ & $\begin{array}{l}.381^{\star \star \star} \\
(4.15)\end{array}$ & $\begin{array}{l}.471^{\star \star \star} \\
(5.74)\end{array}$ & $\begin{array}{l}.376^{* * *} \\
(4.11)\end{array}$ & $\begin{array}{l}.453^{\star \star \star} \\
(5.59)\end{array}$ \\
\hline $\begin{array}{l}\text { Log of unemployment } \\
\text { rate }\end{array}$ & $\begin{array}{l}-.014 \\
(0.17)\end{array}$ & $\begin{array}{l}-.172^{* \star \star} \\
(2.89)\end{array}$ & $\begin{array}{l}-.216^{\star \star \star} \\
(4.11)\end{array}$ & $\begin{array}{l}-.172^{\star \star \star} \\
(2.89)\end{array}$ & $\begin{array}{c}-.209 * * * \\
(3.98)\end{array}$ \\
\hline Constant & $\begin{array}{c}-18.768^{* * *} \\
(7.00)\end{array}$ & $\begin{array}{c}-14.436^{* * *} \\
(6.67)\end{array}$ & $\begin{array}{c}11.351^{\star * \star} \\
(5.96)\end{array}$ & $\begin{array}{c}-14.166^{* \star *} \\
(6.54)\end{array}$ & $\begin{array}{c}-11.426^{* \star \star} \\
(6.09)\end{array}$ \\
\hline $\mathrm{R}^{2}$ & 0.325 & 0.230 & 0.265 & 0.231 & 0.268 \\
\hline No of Observations & 2072 & 3410 & 4045 & 3410 & 4045 \\
\hline Model & Random Effects & Random Effects & Random Effects & Random Effects & Random Effects \\
\hline
\end{tabular}

Notes: Figures in parenthesis are z-statistics, ${ }^{* * *}$ indicates 1 percent significance level, ${ }^{* *}$ indicates 5 percent significance level, *indicates 10 percent significance level. 


\section{Appendix XIIIb - Regression Results for Per Capita Corporate Income Tax Revenue}

(Log of per capita corporate income tax revenue as dependent variable with budget surplus or shortfall variable)

\begin{tabular}{|c|c|c|c|c|c|}
\hline Variable & $\begin{array}{l}\text { States with one } \\
\text { Amnesty }\end{array}$ & $\begin{array}{c}\text { States with one } \\
\text { \& two } \\
\text { Amnesties }\end{array}$ & $\begin{array}{l}\text { States with one, } \\
\text { two, \& three } \\
\text { Amnesties }\end{array}$ & $\begin{array}{c}\text { States with one } \\
\text { \& two } \\
\text { Amnesties }\end{array}$ & $\begin{array}{c}\text { States with one, } \\
\text { two, \& three } \\
\text { Amnesties }\end{array}$ \\
\hline & (1) & (2) & (3) & (4) & (5) \\
\hline $\begin{array}{l}\text { Short-run effect of } \\
\text { Amnesty1 }\end{array}$ & $\begin{array}{l}.303^{* *} \\
(2.15)\end{array}$ & $\begin{array}{l}.132 \\
(1.48)\end{array}$ & $\begin{array}{l}.136^{*} \\
(1.80)\end{array}$ & $\begin{array}{l}.131 \\
(1.47)\end{array}$ & $\begin{array}{l}.130^{*} \\
(1.71)\end{array}$ \\
\hline $\begin{array}{l}\text { Short-run effect of } \\
\text { Amnesty2 }\end{array}$ & & $\begin{array}{l}.161 \\
(\Theta .98) \\
\end{array}$ & $\begin{array}{l}.068 \\
(0.59) \\
\end{array}$ & $\begin{array}{l}.308 \\
(0.98) \\
\end{array}$ & $\begin{array}{l}.226 \\
(1.03) \\
\end{array}$ \\
\hline $\begin{array}{l}\text { Short-run effect of } \\
\text { Amnesty3 }\end{array}$ & & & $\begin{array}{l}.333 \\
(1.18)\end{array}$ & & $\begin{array}{l}.293 \\
(1.03)\end{array}$ \\
\hline $\begin{array}{l}\text { Long-run effect of } \\
\text { Amnesty1 }\end{array}$ & $\begin{array}{c}-.095^{\star *} \\
(1.98)\end{array}$ & $\begin{array}{c}-.089^{* *} \\
(2.46)\end{array}$ & $\begin{array}{c}-.093^{\star * *} \\
(2.76)\end{array}$ & $\begin{array}{l}-.085^{\star *} \\
(2.34)\end{array}$ & $\begin{array}{c}-.086^{* * *} \\
(2.58)\end{array}$ \\
\hline $\begin{array}{l}\text { Long-run effect of } \\
\text { Amnesty2 }\end{array}$ & & $\begin{array}{l}-.053 \\
(0.76)\end{array}$ & $\begin{array}{l}-.110^{* *} \\
(2.24)\end{array}$ & $\begin{array}{l}-.309^{* *} \\
(2.35)\end{array}$ & $\begin{array}{l}-.263^{* * *} \\
(3.07)\end{array}$ \\
\hline $\begin{array}{l}\text { Long-run effect of } \\
\text { Amnesty3 }\end{array}$ & & & $\begin{array}{l}-.484^{* \star *} \\
(3.37)\end{array}$ & & $\begin{array}{c}-.431^{* \star *} \\
(2.95)\end{array}$ \\
\hline $\begin{array}{l}\text { Time difference } \\
\text { between } 1^{\text {st }} \& 2^{\text {nd }} \\
\text { Amnesty (SR Effect) }\end{array}$ & & & & $\begin{array}{c}-.023 \\
(0.87)\end{array}$ & $\begin{array}{l}-.021 \\
(1.16)\end{array}$ \\
\hline $\begin{array}{l}\text { Time difference } \\
\text { between } 1^{\text {st }} \& 2^{\text {nd }} \\
\text { Amnesty (LR Effect) }\end{array}$ & & & & $\begin{array}{l}.029^{* *} \\
(2.30)\end{array}$ & $\begin{array}{l}.019^{* *} \\
(2.09)\end{array}$ \\
\hline $\begin{array}{l}\text { Log of Personal } \\
\text { Income }\end{array}$ & $\begin{array}{l}2.251^{* * *} \\
(9.34)\end{array}$ & $\begin{array}{l}1.830^{* * *} \\
(9.47)\end{array}$ & $\begin{array}{l}1.567^{* * *} \\
(8.75)\end{array}$ & $\begin{array}{c}1.802^{* * *} \\
(9.31)\end{array}$ & $\begin{array}{c}1.601^{* \star *} \\
(9.64)\end{array}$ \\
\hline $\begin{array}{l}\text { Log of Corporate } \\
\text { Income Tax Rate }\end{array}$ & $\begin{array}{l}.504^{\star \star \star} \\
(4.07)\end{array}$ & $\begin{array}{l}.319 * \star * \\
(3.71)\end{array}$ & $\begin{array}{l}.467^{* \star \star} \\
(5.71)\end{array}$ & $\begin{array}{l}.317^{\star \star \star} \\
(3.68)\end{array}$ & $\begin{array}{l}.404^{\star \star \star} \\
(5.27)\end{array}$ \\
\hline $\begin{array}{l}\text { Log of unemployment } \\
\text { rate }\end{array}$ & $\begin{array}{l}.012 \\
(0.15)\end{array}$ & $\begin{array}{l}-.121^{* *} \\
(2.05)\end{array}$ & $\begin{array}{l}-.198^{* \star *} \\
(3.72)\end{array}$ & $\begin{array}{l}-.120^{* *} \\
(2.03)\end{array}$ & $\begin{array}{c}-.160^{* * *} \\
(3.04)\end{array}$ \\
\hline $\begin{array}{l}\text { Budget Surplus or } \\
\text { Shortfall as a percent } \\
\text { of Total Tax Revenue }\end{array}$ & $\begin{array}{l}.124^{*} \\
(1.82)\end{array}$ & $\begin{array}{l}.149 * \star \star \\
(2.68)\end{array}$ & $\begin{array}{l}.053^{* *} \\
(2.20)\end{array}$ & $\begin{array}{l}.154^{\star \star \star} \\
(2.77)\end{array}$ & $\begin{array}{l}.137^{* \star \star} \\
(2.60)\end{array}$ \\
\hline Constant & $\begin{array}{c}-18.821^{* * *} \\
(7.17)\end{array}$ & $\begin{array}{c}-14.755^{\star \star \star} \\
(7.22)\end{array}$ & $\begin{array}{c}-11.531^{* * *} \\
(6.08)\end{array}$ & $\begin{array}{c}-14.489^{* * *} \\
(7.08)\end{array}$ & $\begin{array}{c}-12.122^{\star \star \star} \\
(6.85)\end{array}$ \\
\hline $\mathrm{R}^{2}$ & 0.339 & 0.250 & 0.274 & 0.251 & 0.284 \\
\hline No of Observations & 2072 & 3410 & 4045 & 3410 & 4045 \\
\hline Model & Random Effects & Random Effects & Random Effects & Random Effects & Random Effects \\
\hline
\end{tabular}

Notes: Figures in parenthesis are absolute z-statistics, ${ }^{* * *}$ indicates 1 percent significance level, $* *$ indicates

5 percent significance level, *indicates 10 percent significance level. 


\section{References:}

Agha, A. and J. Haughton, "Designing Vat Systems: Some Efficiency Considerations,” The Review of Economics and Statistics, 78:2 (May 1996): 303-308.

Allingham, M. and A. Sandmo, "Income Tax Evasion: A Theoretical Analysis,” Journal of Public Economics, 1 (1972): 323-338.

Alm, J. and W. Beck, "Tax Amnesties and Compliance in the Long Run: A Time Series Analysis,” National Tax Journal 46 No. 1 (March, 1993): 53-60.

Alm, J. and W. Beck, “Tax Amnesties and Tax Revenues,” Public Finance Quarterly, 18 No. 4 (October, 1990): 433-453.

Alm, J. and W. Beck, “Wiping the Slate Clean: Individual Response to State Tax Amnesties,” Southern Economic Journal 57 No 4 (April, 1991): 1043-1053.

Alm, J., M. McKee and W. Beck, “Amazing Grace: Tax Amnesties and Compliance,” National Tax Journal 43 No. 1 (March, 1990): 23-37.

Alm, J. “Tax Policy Analysis: The Introduction of a Russian Tax Amnesty,” Working Paper 98-6, International Studies Program, Georgia State University, October 1998.

Alm, J., J. Martinez-Vazques and S. Wallace, “Tax Amnesties and Tax Collections in the Russian Federation,” in National Tax Association Proceedings of the $93^{\text {rd }}$ Annual Conference of Taxation, Washington D.C.: National Tax Association, 2000: 239247.

Andreoni, J. “The Desirability of a Permanent Tax Amnesty,” Journal of Public Economics 45 No. 2 (July, 1991): 143-159. 
Box, G.E. and G.C. Tiao, "Intervention Analysis with Applications to Economic and Environmental Problems," Journal of the American Statistical Association 70 (March, 1975): 70-79.

Christian, C. W., S. Gupta, and J. C. Young, "Evidence on Subsequent Filing from the State of Michigan’s Income Tax Amnesty,” National Tax Journal 55 No. 4 (December, 2002): 703-721.

Clotfelter, C. T., “Tax Evasion and Tax Rates: An Analysis of Individual Returns,” The Review of Economics and Statistics, 65:3 (August, 1983): 363-373.

Cnossen, S., “Global Trends and Issues in Value Added Taxation,” International Tax and Public Finance, 5:3 (July 1998): 399-428.

Cnossen, S., "VAT and RST: a Comparison,” Canadian Tax Journal, (1987): 559-615.

Commerce Clearing House, Inc., State Tax Handbook, 1980 - 2003.

Cox, D., "Raising Revenue in the Underground Economy,” National Tax Journal, 37:3 (September, 1984): 283-288.

Crane, S. E. and F. Nourzad, "Tax Rates and Tax Evasion: Evidence from California Amnesty Data,” National Tax Journal, 43:2 (June, 1990): 189-199.

Dubin, J. A., M. J. Graetz, L. L. Wilde, “State Income Tax Amnesties: Causes,” Quarterly Journal of Economics 107 No. 3 (August, 1992): 1057-1070.

Ebrill, L., M. Keen, J. Bodin, and V. Summers, The Modern VAT, Washington D.C.: International Monetary Fund, 2001.

European Commission, "VAT Rates Applied in the Member States of the European Community”, DOC/2908/20002-EN (2002). 
Fedeli, S. and F. Forte, “Joint Income-tax and VAT-chain Evasion,” European Journal of Political Economy, 15:3 (September, 1999): 391-415.

Federation of Tax Administrators, http://www.taxadmin.org/fta/rate/amnesty1.html Federation of Tax Administrators. “State Tax Amnesty Programs” Research Report No 133, Washington D.C., July 1990.

Fisher, R. C., J. H. Godderis, and J. C. Young, "Participation in Tax Amnesties: The Individual Income Tax,” National Tax Journal 42 No. 1 (March, 1989): 15-27.

GAO, Balanced Budget Requirements: State Experiences and Implications for the Federal Government, United States General Accounting Office, Washington, D.C., March 1993.

Gordon, R. H. and S.B. Nielsen, "Tax Evasion in an Open Economy: Value-Added vs. Income Taxation,” Journal of Public Economics, 66:2 (November, 1997): 173197.

Hasseldine, J., “Tax Amnesties: An International Review,” Bulletin for International Fiscal Documentation 52 No. 7 (July, 1998): 303-310.

Joulfaian, D., "Participation in Tax Amnesties: Evidence from a State,” In Proceedings of the Eighty-first Annual Conference on Taxation, Washington D.C.: National Tax Association, (1988): 128-32.

Leccisotti, M. and M. Marè, "On the Presumed Technical Superiority of VAT," Australian Tax Forum, 9:3 (1992): 259-269.

Leonard, H. B. and R. J. Zeckhauser, “Amnesty, Enforcement and Tax Policy,” National Bureau of Economic Research, Working Paper \# 2096, 1986. 
Luitel, H. and M. Tosun, "West Virginia Tax Amnesty: An Evaluation of Costs and Benefits,” The West Virginia Public Affairs Reporter, forthcoming.

Malik, A. S., and R. M. Schwab, "The Economics of Tax Amnesties,” Journal of Public Economics 46 No. 1 (October, 1991): 29-49.

Marè, M. and C. Salleo, "Is One More Tax Amnesty Really That Bad? Some Empirical Evidence from the Italian 1991 VAT Amnesty,” August, 2003.

Marrelli, M., “On Indirect Tax Evasion,” Journal of Public Economics, 25:1-2 (November, 1984): 181-196.

Matthews, K. and J. Lloyd-Williams, “The VAT-Evading Firm and VAT Evasion: An Empirical Analysis,” International Journal of the Economics of Business, 8:1 (February, 2001): 39-49.

Matthews, K., "VAT Evasion and VAT Avoidance: is there a European Laffer curve for VAT?” International Review of Applied Economics, 17:1 (2003): 105-114.

Messere, K., "Half a Century of Changes in Taxation," International Bureau of Fiscal Documentation, 53:8-9 (August - September, 1999): 340-365.

Messere, K., “OECD Tax Developments in the 1990s,” Bulletin for International Bureau of Fiscal Documentation, 51:7 (July, 1997): 298-314.

Messere, K., "Recent Tax Revenue Developments in OECD Countries and Some Policy Implications,” Bulletin for International Bureau of Fiscal Documentation, 47:6 (June, 1993): 323-341. 
Messere, K., "Trends in OECD tax revenues" in "Comparative Tax Studies: Essays in honor of Richard Goode” edited by Sijbren Cnossen. North-Holland Publishing Company. Ch. 2, (1983): 31-57.

Nam, C. W., R. Parsche, and B. Schaden, "Measurement of Value Added Tax Evasion in Selected EU Countries on the Basis of National Accounts Data,” Ifo Studien, 47:2 (2001): 127-144.

National Association of State Budget Officers (NASBO). "Budget Shortfalls: Strategies for Closing Spending and Revenue Gaps,” 4 $4^{\text {th }}$ Edition, Washington D.C., 2004.

OECD, Revenue Statistics 1965-2000, (Paris: OECD, 2001).

OECD, Taxing Consumption, (Paris: OECD, 1988).

Posner, E. A., “Law and Social Norms: The Case of Tax Compliance,” Virginia Law Review, 8 (November 2000): 1781-1819.

Price Waterhouse. Corporate Taxes -- a Worldwide Summary. Various years.

Shoup, C. S., Criteria for Choice among Types of Value-added Tax, Washington DC: The World Bank, 1986.

Slemrod, J., "An Empirical Test for Tax Evasion," The Review of Economics and Statistics, 67:2 (May, 1985): 232-238.

Slemrod, J., "Optimal Taxation and Optimal Tax System," The Journal of Economic Perspectives, 4:1 (Winter, 1990): 157-178.

Sobel, R. S., "The Political Costs of Tax Increases and Expenditure Reductions: Evidence from State Legislative Turnover,” Public Choice 96 No. 1/2 (July, 1998): 61-79. 
Song, Y, and T. Yarbrough, "Tax Ethics and Taxpayer Attitudes: A Survey,” Public Administration Review, (1978): 442-452.

Spicer, M. W., and S. B. Lundstedt, “Understanding Tax Evasion,” Public Finance, 31:2 (1976): 295-304.

Tait, A., "VAT Policy Issues: Structure, Regressivity, Inflation and Exports," edited by Alan A Tait in Value-Added Tax: Administrative and Policy Issues, Washington DC: International Monetary Fund, (1991): 1-16.

Tait, A., Value Added Tax, New York: McGraw-Hill Book Company, 1972.

Tait, A., Value Added Tax: International Practice and Problems, Washington DC: International Monetary Fund, 1988.

Torgler, B. and C. A. Schaltegger, “Tax Amnesty and Political Participation,” University of Basel, WWZ, 2003.

Torgler, B., C. A. Schaltegger, and M. Schaffner, "Is Forgiveness Divine? A CrossCulture Comparison of Tax Amnesties," Schweizerische Zeitschrift für Volkswirtschaft und Statistik, 139:3, (2003): 375-396.

Tosun, M. and S. Abizadeh, "Economic Growth and Tax Components: an Analysis of Tax Changes in OECD,” Applied Economics, forthcoming.

Uchitelle, E., "The Effectiveness of Tax Amnesty Programs in Selected Countries,” Federal Reserve Bank of New York Quarterly Review, 14, (Autumn 1989): 4853.

United States Census Bureau, State Government Finances, Washington, D.C. 
United States Census Bureau, State Government Finances, Washington, D.C., Book of the State, various years.

United States Census Bureau, State Government Finances, Washington, D.C., Statistical Abstract of the United States, various years.

United States Congress, Joint Committee on Taxation. Tax Amnesty (JCT-2-98).

Washington, D.C., 1998.

United States Department of Commerce, Bureau of Economic Analysis, State and Local Personal Income, Washington, D. C.

United States Department of Labor, Bureau of Labor Statistics, Demographics, Washington, D.C.

United States Treasury Department, “Tax Reform for Fairness, Simplicity and Economic Growth,” The Treasury Department Report to the President. Washington DC: Office of the Secretary, Department of the Treasury, Vol. 3: Value Added Tax, (1984).

Virmani, A., "Indirect Tax Evasion and Production Efficiency," Journal of Public Economics, 39:2 (July, 1989): 223-237.

Vogel, J., “Taxation and Public Opinion in Sweden: An Interpretation of Recent Survey Data,” National Tax Journal, 27:4 (December, 1974): 499-513.

Warren Marketing Group, “Maine Tax Amnesty Report May 1991,” Warren Marketing Group, Commonwealth Marketing and Development, Portland, Maine.

World Bank, World Development Indicators 2003 CD-ROM, (2003) 
Yaniv, G., “Tax Evasion and the Income Tax Rate: a Theoretical Reexamination,” Public Finance, 49:1 (1994): 107-112.

Yitzhaki, S., “A Note on Income Tax Evasion: A Theoretical Analysis,” Journal of Public Economics, 3:2 (May, 1974): 201-202.

Zellner, A. and F. Palm, “Time Series Analysis and Simultaneous Equation Econometric Models,” Journal of Econometrics, 2 (May, 1974): 17-54. 